Portland State University

PDXScholar

$11-1-1994$

\title{
British Aristocratic Women and Their Role in Politics, 1760-1860
}

Nancy Ann Henderson

Portland State University

Follow this and additional works at: https://pdxscholar.library.pdx.edu/open_access_etds

Part of the History Commons

Let us know how access to this document benefits you.

\section{Recommended Citation}

Henderson, Nancy Ann, "British Aristocratic Women and Their Role in Politics, 1760-1860" (1994).

Dissertations and Theses. Paper 4799.

https://doi.org/10.15760/etd.6682

This Thesis is brought to you for free and open access. It has been accepted for inclusion in Dissertations and Theses by an authorized administrator of PDXScholar. Please contact us if we can make this document more accessible: pdxscholar@pdx.edu. 


\section{THESIS APPROVAL}

The abstract and thesis of Nancy Ann Henderson for the Master of Arts in History were presented November 1, 1994, and accepted by the thesis committee and the department. COMMITTEE APRROVAIS:

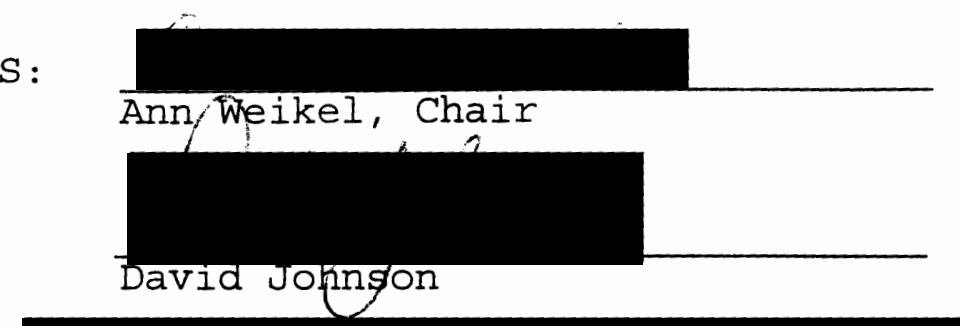

DEPARTMENT APPROVAI:

Susan Karant-Nunn

Christine Thompson

Representative of the office of Graduate studies

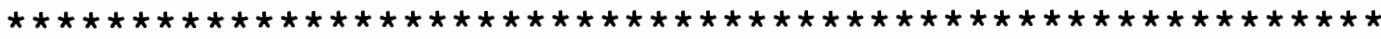

ACCEPTED FOR PORTLAND STATE UNIVERSITY BY THE LIBRARY by on $12 \alpha 4$ Lentex 1994 


\section{ABSTRACT}

An abstract of the thesis of Nancy Ann Henderson for the Master of Arts in History presented November, 1, 1994.

Title: British Aristocratic Women and Their Role in Politics, 1760-1860.

British aristocratic women exerted political influence and power during the century beginning with the accession of George III. They expressed their political power through the four roles of social patron, patronage distributor, political advisor, and political patron/electioneer. British aristocratic women were able, trained, and expected to play these roles. Politics could not have existed without these women. The source of their political influence was the close interconnection of politics and society. In this small, inter-connected society, women could and did influence politics. Political decisions, especially for the Whigs, were not made in the halls of government with which we are so familiar, but in the halls of the homes of the social/political elite. However, this close interconnection can make women's political influence difficult to assess and understand for our twentieth century experience.

Sources for this thesis are readily available. Contemporary, primary sources are abundant. This was the age 
of letter and diary writing. There is, however, a dearth of modern works concerning the political activities of aristocratic women. Most modern works rarely mention women.

Other problems with sources include the inappropriate feminization of the time period and the filtering of this period through modern, not contemporary, points of view. Separate spheres is the most common and most inappropriate feminist issue raised by historians. This doctrine is not valid for aristocratic women of this time.

The material I present in this thesis is not new. The sources, both contemporary and modern, have been available to historians for some time. By changing our rigid definition of politics by enlarging it to include the broader areas of political activities such as social patron, patronage distributor, political advisor, and political/electioneer, we can see British aristocratic women in a new light, revealing political power and influence. 


\title{
BRITISH ARISTOCRATIC WOMEN
}

AND THEIR ROLE IN POLITICS, 1760-1860

by

NANCY ANN HENDERSON

A thesis submitted in partial fulfillment of the requirements for the degree of

\section{MASTER OF ARTS \\ in \\ HISTORY}

\author{
Portland State University \\ 1994
}


TABLE OF CONTENTS

PAGE

CHAPTER

I INTRODUCTION $\ldots \ldots \ldots \ldots \ldots \ldots \ldots \ldots$

I I POLITICAL HOSTESS..............29

II I PATRONAGE DISPENSER...........76

IV POLITICAL ADVISOR..............99

V ELECTORAL INFLUENCE.............148

VI CONCLUSION.................209

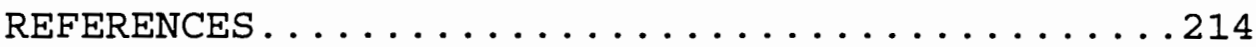

APPENDIX A BIOGRAPHICAL NOTES...........250

APPENDIX B GENEALOGICAL CHART OF THE GRAND WHIGGERY................... 299 
CHAPTER I

INTRODUCTION

British aristocratic women exerted political influence and power during the century beginning with the accession of George III. They expressed their political power through the four roles of social patron, patronage distributor, political advisor, and political patron/electioneer. British aristocratic women were able, trained, and expected to play these roles. Politics could not have existed without these women. The source of their political influence was the close interconnection of politics and society. A close examination of the way politics worked during this time period reveals the political power of aristocratic women. This was not the age of the professional politician, nor of professional politics.

There was a small number of peers who controlled both society and politics. The smallness of the ruling class and the limited franchise made political control a family affair. Primogeniture and a surplus of well-born but comparatively poor younger sons demanded a political and social system to support them. ${ }^{1}$ 
In this small, inter-connected society, women could and did influence politics. Political decisions, especially for the Whigs, were not made in the halls of government with which we are so familiar, but in the halls of the homes of the social/political elite. To study the politics of this time without recognizing its close relationship with society is poor scholarship. However, this close interconnection can make women's political influence difficult to assess and understand from our twentieth century experience. So it is important to define political activities of British aristocratic women in this eighteenth - nineteenth century context, not from a late nineteenth or twentieth century one. The political power and influence that British aristocratic women exerted stemmed from their vital role in this political/social structure.

Political activity defined in its most narrow sense is electoral politics. By this definition women of this time could not be a part of the electoral process because they could not vote. There are two dangers in having such a narrow definition of political activity. First, it eliminates women from political consideration, it directs the study of women and politics to the struggle for suffrage, and it ignores all other political activities of women. Second, the narrow definition of politics denies a complete understanding of politics as a whole in this time period. Women were active 
and played a vital role in politics, including elections, without having the vote. Judith Lewis, through her research on childbearing and the aristocracy, was "struck by the heady, highly political atmosphere in which women lived. For many, political discussion and political activity were the intellectual mainstay of life." ${ }^{2}$ We need to expand the definition of politics and political activity to reflect more accurately the political activity of both men and women of the time. D. Easton, a popular twentieth century political theorist, proposed a expanded and more appropriate definition of politics which is valid for our century and the two earlier ones. "People may be said to be participating in political life when their activity relates in some way to the making and execution of policy for society". ${ }^{3}$ Politics is the process of the authoritative allocation of values in a society. It includes "voting, candidates, party activism, pressure group membership, and extra-institutional informal activity of any kind aimed at influencing the policy makers." ${ }^{4}$ By this definition, with the exception of the first two items listed, women did participate in and were a vital component of politics.

This was a long time period to discuss thoroughly. It included four monarchs and one regent, numerous prime ministers, endless political parties and factions, wars with America and France, and the Industrial Revolution with its 
continuing social unrest. While long, the period does have its own unity. 1760 and the ascension to the throne of George III marked a turning point in the political and social history of Britain. With George III came the rise to power of the Tories which forced the Whigs to develop a non-court political power structure, one that had women at its foundation. Perhaps the passing of the 1832 Reform Bill would have been a suitable cutoff date for this thesis. However, instead of bringing about the end of aristocratic influence, it instead brought about the revival of the aristocratic led Whig party with women at its heart. Instead of 1832, I cut off discussion around the death of Emily, Lady Cowper/Palmerston. She was perhaps the last politically influential aristocratic woman of the type described in this thesis. I see the political activities of women as part of a continuum of political activities stretching over the centuries. In this one hundred years alone, we can trace the political power and influence through four generations of Spencer women and two generations of Lamb women. ${ }^{5}$

This thesis focuses on British women. For the most part I have focused on English women, mainly those based around London, the center of the socio-political nexus. However, I have included two Scottish women, the Duchess of Gordon and the Countess of Sutherland, both of whom were politically active in both countries. With the exception of 
the Princess Lieven, the wife of the Russian Ambassador to London, I have excluded foreign-born women. Although not British, Lieven typified the qualifications and activities of British women active in politics. She played such a strong political role during her twenty-two years in Britain that I could not exclude her. It is the close connection of British politics and society (and her expert manipulation of the connection) that allowed her to be so politically powerful. Although I have Iimited this thesis to British women, it does not mean that women in other countries were politically inactive. A very useful comparison could be made between the political activities of British, American, and French women. " 6

This thesis focuses on aristocratic women, or the upper class, usually made up of hereditary nobility. I also made exceptions for a few women, who, while not being of the aristocracy itself, exemplify many of its political qualities, for example, Fanny Burney and Hester Thrale.

British women of all classes were politically active during this period. It is a fallacy to assume that only aristocratic women participated in politics, that women of the working class or middle class were too occupied with home and hearth to follow politics. "Women of the middle class had no such personal contacts [with politics] to stimulate their interest in politics and were consequently more or less 
indifferent to public affairs." ${ }^{7}$ However, Karl Von Den Steinen believed that a "careful combing of published and unpublished sources of English local history" does show that women of many classes held various political offices. ${ }^{8}$ There simply are more sources available for the study of aristocratic women. Middle class and working class women are not as accessible to us yet.

With few exceptions I chose to focus on women from the Whig and Tory parties. One exception is Mother Grote, the "formidable" wife of the historian, the "Madame Defarge designate of the English Revolution." "9

The vast majority of political British aristocratic women were married. Even though many came from active political families and were raised in a strongly political atmosphere, it was not until they married that they were able to be a force politically. There were exceptions. Important political women who never married included Emily Eden, Hester Stanhope, and Miss Berry. They were still able to be politically active, campaigning, advising, and controlling the socio-political nexus even though they were not married. Their power came from their positions within their own powerful political families. Widows were also able to wield political power. The mother of Georgiana Duchess of Devonshire, the Countess spencer, continued to manage the family interests in their constituencies well after the death 
of her husband, the first Earl spencer. Other powerful widows include Katherine Lowther, Duchess of Dorset, Duchess of Newcastle, and the Countess of Durham. However, the vast majority of politically active women were married.

For most women, political power and influence required marriage. However, only rarely did it require marriage to a politically active husband. Almost all British aristocratic women active in politics married relatively ineffective husbands, husbands who were politically and socially weak. This was a common thread that ran throughout both whig and Tory families. This brings up the question - why marry? The political social alliance running politics and society relied upon the strength and ability of its women and not its men. Marriage gave British aristocratic women the independence to pursue political power and influence. Even through unhappy marriages and multiple births, British aristocratic women continued their political activities. How much of the political activity of British aristocratic women was "political wifery"? Actually very little since the majority of women studied in this thesis married political lightweights. Their political activities stemmed from their desire to support family not the spouse. It was only towards the end of the period that we see the rise of political wifery, such as wives appearing next to their husbands on the 
hustings. With the rise of professional politicians came political wives.

Georgiana, the Duchess of Devonshire, was an example of a capable woman married to a man, who, though nominally of a strong and powerful political family, was "one of the most apathetic of men"10 The duke, "altogether a strange man, taciturn and cold ... never played a significant role in government." 11 Georgiana became the central figure in the political social circle surrounding Charles Fox, almost immediately after her marriage to the duke. This was what she trained for and also because it provided excitement and interest in her life.

Peniston Lamb, the husband of Elizabeth, Lady Melbourne, was also a weak man. He was "hardly worthy of such an alliance. He was affable ... lazy, self-indulgent, lecherous, a weak and stupid man."12 Peniston showed little interest in politics. He sat in the House of Commons from the age of 22 dimly following the lead of Lord North, speaking only once in over 40 years."13 $\mathrm{His}$ politics tended toward the Tory viewpoint but he had little influence, certainly not enough to overcome the powerful influence his wife exerted for the Whig cause.

As a contrast to the husbands of Georgiana and Lady Melbourne, Lord Holland was at least a pleasant personality, a "cheerful, good humored man", "one of the most delightful 
men that ever lived." ${ }^{14}$ Elizabeth, Lady Holland, married a man who was both from a powerful political family and relatively powerful himself. He was accepted in the inner circles of the Whig party and Holland House saw many cabinet meetings. However, Elizabeth easily surpassed him in political power. It was she who established Holland House as the great political and social center and kept him politically active. Lord Holland was an "indifferent politician." 15 Despite his seniority, his popularity, and his unrivalled knowledge of foreign affairs, he was not made Foreign secretary when the Whigs finally came to power in 1830. Most other politically active British aristocratic women also had weak husbands. Princess Lieven, while first relying on the influence of her husband, soon became the powerful and influential partner in the marriage. "Prince Lieven was always very much supposed to act according to her suggestions." 16

One important quality politically active British aristocratic women had was being part of political families either by birth, by marriage, or, most often, by both. The "family was the basic political unit in society, the source of influence and power." ${ }^{17}$ Georgiana, Duchess of Devonshire, was a good example of the role British aristocratic women played in their own family and that of their husband. Georgiana was part of the prominent spencer clan. Georgiana 
"belonged to a family which was hereditarily predisposed to meddle in the affairs of the state. Her friends in the intervals between their pleasures, devoted themselves wholeheartedly to the business of the nation. The atmosphere in which she moved was thus strongly political."18 She was descended in the third degree from Sarah, Duchess of Marlborough and upon her marriage to the duke, she immediately became involved in the Cavendish family political structure. The best example of the political power of families was the Whig aristocracy. (See Appendix B for genealogical chart of the Whig Aristocracy.)

The Whig aristocracy was the foundation of mideighteenth to mid-nineteenth century political and social life. The whig aristocrats set the tone, established and maintained the rules of action and behavior, and provided the cohesiveness necessary to sustain the whig party in and out of political power. This Whig Aristocracy was ruled by women.

Women provided the cohesiveness necessary to sustain the whig political party through thirty years out of political office, numerous factional splits, and the difficult years of political reform. It was the women who established and maintained the centers of the whig party over the years. Beginning with Georgiana and Lady Melbourne, and proceeding to Lady Holland and Lady Cowper, Whig women not 
only kept the party alive, but also directed its development. They established and maintained meeting places, invited the vital people, vetted new political talent, directed patronage, were political advisors to the important male political leaders, and were electoral patrons and participated in elections. It was these women, not their husbands, who established and maintained their family homes and estates as Whig strongholds and headquarters. Most notably, Devonshire House, Holland House, and Panshanger were, in turn, headquarters of the Whig party.

The great Whigs "sat on such a social eminence that they regarded even the royal family as slightly parvenu and had contempt for courtiers who guarded their status. Their confidence was almost unthinking." ${ }^{19}$ This was a golden age of the British aristocracy; they were rich, powerful and glamorous. Whigs were in opposition for forty-six out of the forty-seven years between 1783 and 1830. But within the Whigs there was "surprisingly little self-doubt." 20 Thus was due to the Whig cohesiveness supplied by the political social link controlled by women. "Familial loyalties gave them unrivalled cohesiveness, despite the fact that they differed among themselves over almost every political issue except Catholic Emancipation." 21 Indeed the weakness of the Whigs was not in principles of political responsibility and public service, but in the difficulties of translating them into 
action. This high degree of cohesiveness was "something of a unique phenomenon in later eighteenth century politics." 22

At the heart of the Whig aristocracy was the Grand Whiggery or the confluence of the great whig families. "No Whig government could hope to survive for long or call itself Whig without support from the great families, most of them cousins by blood or marriage, whose surnames and titles were inextricably bound up with mythology anchored in the events of 1688-9." ${ }^{23}$ The Ponsonbys, Russells, Bentincks, Temples Fitzroys, Pelhams, Lennoxes, Cavendishes, and Wentworths were thus "at the center of the tightly-organized 'cousinhood' of aristocratic families which dominated whig politics and society, all shepherded by those great salonieres." ${ }^{24}$

political power was essential to maintenance of the whig families.

This Whig power was bred into British aristocratic women. Georgiana's father was a Whig, his children were Whigs and married other Whigs. Georgiana's children did the same. Georgiana, like other whig women, grew up talking politics. The "leaders of Whig society were exposed to the fascinating world of politics as children and they in turn amused their own offspring with bits and pieces of political gossip." Georgiana's daughters and granddaughters "constantly mixed with clever men and listened to good conversation, political, literary and artistic and they were 
all observant, intelligent women." 26 Lady Bessborough described her childhood in the spencer household "From my childhood I have been accustomed to hear politics the constant and eager subject of conversation." 27 Not only did Fanny Elliot hear politics freely discussed as a child, she with "childish enthusiasm entered into the great causes which the leaders, with whom she came in contact had so much at heart, but early in her life she began to have experience of affairs in her own person and at close quarters." 28

The power of Whig women in the whig aristocracy continued throughout the time period covered by this thesis. We can see this through the multi-generational impact of the Cavendish women. At the beginning was Lady spencer, then Georgiana and Lady Bessborough, then Georgiana's daughters Georgiana and Harriet, and their children. One author was amazed at how remarkably attractive the life of high culture and high politics pursued by the Devonshire House set remained through the many generations of spencer women. ${ }^{29}$ Harriet, great-granddaughter of Lady Spencer, was the "picture of her mother, Lady Carlisle, worldly, sociable, and intensely political. ${ }^{30}$ she drew out of her older and more reserved Gower husband out into the political world and established at stafford House an important political. Women continued to direct the whig party until the end of the nineteenth century. ${ }^{31}$ 
Women were especially noted for keeping the whigs together during the long years out of power. However, British aristocratic women were equally vital while the whigs were in power, especially during the period of 1830-1852 when the Whigs ruled. The 1832 Reform Bill did not destroy aristocratic influence. One author argued that the decades following the bills's passage demonstrated immense power for the aristocracy, and especially the revival of the whig aristocracy. "They did not become absolutely central to the party's leadership and organization until after 1830."12

Tory women aristocrats, to a lesser degree, exerted much of the same political power as Whig women. Jane, Duchess of Gordon, established her London mansion as the chief meeting place of the leaders of the Tory party, as the mansion of the Duchess of Devonshire was of the Whigs. ${ }^{33}$ Another author, however, said that Jane never "obtained the influence which Lady Holland exercised in the Whig party". Other Tory centers in London were the homes of the Duchesses of Newcastle and Northumberland. The home of the Grotes was a headquarters of the Radical party. Parkes described the Radicals as Mrs. Grote's coterie. ${ }^{34}$ Edward Ellice in Jan 1837, sarcastically stated the "loving people of England and Scotland have quite made up their minds to overturn the throne, the aristocracy, and other institutions of the 
country, to seek for better government from Sir $W$. Molesworth, Mr. Roebuck, and Mrs. Grote." 35

Major sources for this thesis fall into three groups: primary sources consisting of diaries, journals, and letters; works by contemporary historians; and studies by later historians. Contemporary, primary sources are abundant. This was the age of letter writing. We have material of many of the women discussed in this thesis including Georgiana, Duchess of Devonshire, Lady Bessborough and their daughters and granddaughters. However, we do lack material from Elizabeth, Lady Melbourne and Jane, Duchess of Gordon. Mrs. Arbuthnot and Lady Shelley have published material and the correspondence of Horace Walpole runs over forty large volumes. Other contemporary writers include Dod, Croker, and Wraxal1. Contemporary newspapers, such as the Morning Post are also readily available.

However, there is a dearth of modern, non-contemporary, works concerning the political activities of aristocratic women. Most modern works barely mention women. One very recent social history of Britain did not mention women at al1. ${ }^{36}$ Von Den steinen rightly notes his frustration when he says "one must now choose between politics without women or women without politics." ${ }^{37}$ Later historians fall into two camps: the traditional (mostly male) and the feminist. Standard reference material includes the Dictionary of 
National Biography, the two histories of the House of Commons by Lewis Namier \& John Brooke and R. G. Thorne.

There are two modern authors who discuss the theme of this thesis: Lewis and Von Den steinen.

Judith Lewis was the only historian to discuss the political roles of women during this period in an article called "Political Behavior of Elite Women in England 17741832", published in 1983. She recognized the political importance of women and the close interconnection of politics and society, discussed three of the four political roles described in this thesis, and provided limited information but a good flavor of women's political activities. Her sources were excellent and wisely chosen and her coverage of the political hostess and patronage dispenser roles provided a good sampling of these activities. Of the three roles Lewis's coverage of electoral activities was the most extensive. However, she inappropriately used the terms campaigning and canvassing interchangeably. As my thesis shows, women's participation in electoral campaigns involved more than canvassing. Lewis also never grasped the role of the electoral patron.

Lewis chose to start her article with the "most visible" political role of electoral canvasser. However, I argue that, while it may be the most visible to us today, to contemporaries the other roles were more visible and more 
fundamental to their political system. I chose to start my thesis with the other three roles. We need to understand these before we can comprehend the impact and importance of the campaigner role. Her article has two additional flaws. First, she did not discuss the fourth role of political advisor. This role, while obvious to contemporaries, was difficult for me to grasp. It was only after completing the majority of my research that $I$ was able to identify that activity and recognize its importance. Lewis's second flaw, her insistence on the validity of separate spheres, will be discussed below.

Karl Von Den Steinen succeeded well in his purpose for writing his bibliographic essay "The Discovery of women in Eighteenth-Century Political Life" - to provide questions, identify possible source material, and discuss problems in conducting research in this area." ${ }^{38}$

While accurate on the scholarship needs and problems, his understanding of the political roles of women was faulty. Women's political activities "must nearly always be measured through the achievements of men." ${ }^{39}$ To him political activity had no value unless it influenced men successfully. My thesis discussed political activities as a source of information about women and politics of the time, not whether they were successful or not. The end goal for women was political influence and power; the process was as important 
as the result. Moreover, my thesis proves British aristocratic women were successful in their political activities. Von Den steinen's reading of primary sources has been slight or he would have seen the value women and men placed on female political activities. He also did not address the question of how much more direct were male political activities. Were not men involved in advising, campaigning, etc. for other male politicians? Von Den Steinen's biggest problem in this rambling essay was that he never defined political activity. He talked about patronage, political hostesses, and electioneering but dismissed these roles as irrelevant or remaining to be assessed. This article also suffered from an overconcentration on suffrage and women's rights, and an over emphasis material prior to 1760. However, he did raise very useful, thoughtful questions and suggestions for future research.

Beyond these two articles, there are three major problems with the secondary sources for this thesis: their avoidance of the entire period; their inappropriate feminization of the period or their determination to see this time through feminist colored glass; and their filtering of this period through modern points of view.

First, this period has not been popular with either traditional or feminist historians. For the former, the influence of Namier and the "Whig Interpretation of History" 
has been too overpowering. They also perceived the period as too complicated and lacking a central point of focus. ${ }^{40}$ It even lacked good, clean opening and closing dates. The feminist historians ignored this age because they perceived it as a failure. Concentration on Mary Wollstonecraft and other feminists leads to despair; nothing came of Wollstonecraft's ideas. They perceived no progress on women's rights. Instead feminist historians tend to skip from Sarah, Duchess of Marlborough (d.1744), to the late nineteenth-century fighters for women's rights. They ignored the women in between. Feminist historians also tended to avoid discussion of aristocratic women, believing them to be ineffectual, pampered pets. There has been some focus on women writers of the time such as Fanny Burney. However, by avoiding this age feminist historians have discarded both a treasure of available and relatively unworked material and the existence of politically important women. Political influence derived from and for family power was not as dramatic as suffragists throwing themselves under coachwheels. Yet, reading the letters of these women made it apparent how important they were to politics and how important politics was in their lives.

Second, feminist historians by insisting on overfeminizing this period, are incapable of discussing the political influence of women. (I define over-feminization as 
the process of placing all activities of women in the context of women's rights.) Throughout my readings of primary sources materials, I found extremely few references to contemporary women's rights by aristocratic women. This stemmed from the fact that British aristocratic women had their influence and power and were content with it. Even Judith Lewis, in her ground breaking article, made the mistake of many writers of women's history. She believed that the political activities of these women were less valuable because they did not immediately lead to voting rights for women. Somehow Georgiana, Duchess of Devonshire and Elizabeth, Lady Holland failed to maintain the flame of women's rights going. The century that started out so conspicuously with Mary Astell and also produced Mary Wollstonecraft should have resulted in rights for women. Lewis accepted this notion of failure and tried to explain it. I do not believe these women failed. British aristocratic women of this time did have political power and influence. Lewis did not understand the close interconnection between politics and society and how that gave aristocratic women political power.

Separate spheres was the most common and most inappropriate feminist issue raised by historians. This doctrine was not a valid one for the women of this time. The political and social structure depended upon both the social 
and political participation of aristocratic women. I found very few examples of contemporaries expressing the opinions that women did not belong in politics. During this time, Samuel Johnson stated that women could not be ministers (a woman preacher is like a dog walking on its hind legs...). Yet he never made a similar statement about women politicians. Indeed, he supported Hester Thrale's campaign for her husband's parliamentary seat in Southwark. The 1784 Westminster election aroused the most contemporary feelings of women not belonging in politics. The Tory press used this criticism against Georgiana, Duchess of Devonshire and her effective campaign for Charles Fox. However, this was the exception. Elsewhere, the contemporary documents did not support the concept of separate spheres that feminist historians misapply here. Lewis made two contradictory statements in her article. First she said she believed that the doctrine of separate spheres was valid. Then she stated that "political campaigning by elite women represented, not a flight from traditional family responsibilities, but a confirmation of them." 41 If women's political activity was part of the familial structure of the time, how could it be considered not part of women's sphere?

Third, modern historians continually apply modern points of view to eighteenth and nineteenth-century women. Von Den Steinen stated that individual women were active in 
politics for only short lengths of time. ${ }^{42}$ This assumes that short lengths of time had less value. Most men were not politically active for long periods either. Moreover, many British aristocratic women, such as Elizabeth Lady Holland and Emily Lady Cowper/Palmerston, participated in politics all their adult lives (usually through multiple childbirths and illness, and sometimes through multiple marriages). Georgiana, Duchess of Devonshire was politically active until her death, yet most historians only discuss her role in the 1784 Westminster election and the 1788/9 Regency Crisis. Soulbury believed that women were more interested in personalities than in issues. This implies that issues were more important and that men were interested in issues not personalities. However, most politics during this time was based on individuals, for both sexes. Issues such as foreign policy (war with America and France, diplomacy with Russia) and domestic issues (economy, Catholic Emancipation) concerned both sexes.

The material I present in this thesis is not new. The sources, both contemporary and modern, have been available to historians for some time. By changing our rigid definition of politics by enlarging it to include the broader areas of political activities such as social patron, patronage distributor, political advisor, and political/electioneer, we can see British aristocratic women in a new light, revealing 
power and influence. Through my reading of contemporary material, journals, letters, and diaries of both men and women, we can see very clearly that women were a vital component of the political process of their times.

Their political activities were not unusual for the time. There was nothing unique about the political activities of women in this time period. Each of the four roles was also performed by men. Women may have given more dinners, but there were plenty of stag affairs. Women may have placed people in office but they did this through interaction with men. Men also advised and electioneered. Women controlled who was politically and socially acceptable, but obviously men were involved. Men also advised and electioneered. To the uninformed historian, the lack of adequate historical coverage has made these women and their political influence seem unique. Women were not unique but actively influencing, controlling, and directing. My perspective is unique, not the women.

This thesis includes a large amount of material. There were issues I wished to discuss but could not, due to time and space constraints. A closer study of the doctrine of separate spheres and British aristocratic women is needed, especially using a cross-cultural comparison of elite women of the time. I wish I could have discussed further the motives for women participating in politics. There is enough 
evidence to sustain an argument that women's motives were the same as men's - family, party/faction, and self. Finally, it was suggested to me $\mathrm{m}^{43}$ that it would have been useful, after discussing the four political roles, to take one issue, such as the Reform Bill of 1832, and explore how women as political hostesses, patronage distributors, political advisors, and electioneers impacted the issue. This type of analysis would provide another clear insight into the importance of British aristocratic women to the political process of their time. 
ENDNOTES FOR CHAPTER I

${ }^{1}$ There was a small group of peers and rich commoners at the top of society and politics. Society was exclusive with fewer than 300 families. Jupp refers to the "landed elite, estimated at between 6,000 and 10,000" but he also includes gentry in this group in Peter J. Jupp, "The Landed Elite and Political Authority in Britain, ca. 1760-1850," Journal of British studies 29 (1990):54. Population as a whole grew from 4.9 million in 1688 to 8.9 million in 1801 , to 13 million in 1832, to 29 million in 1900. Linda Colley "The politics of Eighteenth Century British History," Journal of British Studies 25 (1986):371.

${ }^{2}$ Judith Lewis S., "Political Behavior of Elite women in England 1774-1832," Consortium of Revolutionary Europe, 17501226 Proceedings, (1983):244.

${ }^{3}$ Quoted in Melville Currell, Political Women, (London: Croom Held, 1974), p. 3.

${ }^{4}$ Currell, Political Women, p. 3.

${ }^{5}$ Additional useful discussions could have been comparing the political activities of British aristocratic women of the eighteenth century from Sarah, Duchess of Marlborough to Georgiana, Duchess of Devonshire or the nineteenth century of Lady Cowper/Palmerston to Lady Carlisle, daughter of Lord Stanley.

${ }^{6}$ See Soulbury, Herwald, "Women of Influence," Ouarterly Review, 297 (1959) for a comparison of French and British women's political activities. See Ruth Frow, Political Women 1800-1850, (London: Pluto Press, 1989) for examples of American women in elections.

${ }^{7}$ Soulbury, "Women of Influence", p. 402. Moreover, while Soulbury grasps the personal nature of politics of this time period, he neglects to discuss whether he thought middle class men were also politically indifferent, because they too had no personal contacts with politics.

${ }^{8}$ Karl Von Den Steinen, "The Discovery of Women in Eighteenth-Century English Political Life" in the Women of England From Anglo-Saxon Times to the Present edited by Barbara Kanner, (Hamden, CT: Archon, 1979), p. 241.

${ }^{9}$ Philip Ziegler, Melbourne, A Biography of William Lamb, Second Viscount Melbourne, (New York: Knopf, 1976), p. 246. In addition I found one reference to a political salon 
established by an aristocratic women (Lady Blessington) for the Radicals, Neville Blackburne, Ladies Chain, (Iondon: Falcon Press, 1952), p. xiii.

${ }^{10}$ Edmond de Goncourt, The woman of the Eighteenth Century, (New York: Minton, Balch, 1927), p. 127.

${ }^{11}$ Although very intelligent, the Duke only spoke two times in the House of Lords. Hugh Stokes, The Devonshire House Circle, (London: H. Jenkins, 1917), p. 215.

${ }^{12}$ Mabell Airlie, In Whig Society, (London: Hodder and Stroughton, 1921), p. 3 .

${ }^{13}$ David Cecil, Melbourne, (Indianapolis: Bobbs Merrill, 1939, 1954), p. 30 .

${ }^{14}$ "Review of 'Life, Letters, and Journals of Sir Charles Lyell, " Quarterly Review 153 (1882), p. 115 .

${ }^{15}$ Boyd Hilton "Review of 'Holland House' by Leslie Mitchell", Parliamentary History 2 (1983), p. 251. A contemporary, Charles Lyell, put his finger on the character of Lord Holland, saying Holland talked of "anecdotes of political men, rather than politics." "Review of 'Life, Letters, and Journals of Sir Charles Lyell,' " Quarterly Review 153 (1882), p. 115.

${ }^{16}$ Percy Fitzgerald, The Iife of George the Fourth, (London: Tinsley Brothers, 1881), vol. 2, p. 429. Other women with weak husbands included Harriet, Lady Bessborough, whose husband was a "dim Whig grandee who has left only the most vestigial traces of his existence." Ziegler, Melbourne, p. 43; Jane, the Duchess of Gordon, who married a man "who wanted her energy of character." Nathaniel Wraxall, posthumous Memoirs, (Philadelphia: Carey, Lea, and Blanchard, 1836), p. 478; Lady Clanricarde married "a poor creature a great gawky schoolboy who grins at everything that is said." Thomas Babington Macaulay, Letters, edited by Thomas Pinner, (Cambridge University Press, 1974), p. 67. Lord Melbourne, the Prime Minster, described the Clanricarde relationship. "There is Clanricarde himself, a little insipid in character, of diplomatic abilities unknown, of discretion doubtful, and then there is Lady Clanricarde, a clever, lively woman thinking and talking of nothing but politics, a decided enemy" quoted in Kenneth Bourne, Palmerston the Early Years 1784-1841, (New York: Macmillan, 1982), p. 465; and Emily, Lady Cowper/Palmerston, the daughter of Lady Melbourne, who married a man who, though eventually a Prime Minister, lacked the same ability she had. "Palmerston patently lacked political passion or real political ambition. All of his 
most intimate women happened to be very political." Bourne, Palmerston, p. 629 .

${ }^{17}$ Lewis, "Political Behavior," p. 248.

${ }^{18}$ Stokes, Devonshire House Circle, p. 192.

${ }^{19}$ Ellis Wasson, "The Great Whigs and Parliamentary Reform, 1809-1830", Journal of British Studies 24 (1985):451.

${ }^{20}$ Hilton, "Review," p. 251.

${ }^{21}$ Ibid., p. 25I. Indeed the weakness of the Whigs, was not in principles of political responsibility and public service, but in the difficulties of translating them into action.

${ }^{22}$ E. Anthony Smith, Whig Principles and Party politics, (Manchester University Press, 1975), p. x.

${ }^{23}$ Wasson, "The Great Whigs," p. 435.

${ }^{24}$ Smith, Whig Principles, p. 27.

${ }^{25}$ Diana Olien, Morpeth: A Victorian Public Careex, (Washington, D. C.: University Press of America, 1963), p. 21.

${ }^{26}$ Maud Leconfield, Three Howard Sisters, (London: John Murray. 1955), p. xi.

${ }^{27}$ Granville, Lord Granville Leveson Gower Private Correspondence, $2: 218$.

${ }^{28}$ For example with Bismarck in Berlin. She also saw the disposition of Charles X. Elizabeth Lee, Wives of the Prime Ministers, (London: Nisbet, 1918), p. 65-66.

${ }^{29}$ Peter Mandler, Aristocratic Government in the Age of Reform, (Oxford: Clarendon, 1990), p. 50 .

${ }^{30}$ Ibid., p. 51.
${ }^{31}$ Ibid., p. 279.
${ }^{32}$ Ibid., p. 44.

${ }^{33}$ William Anderson, The Scottish Nation, (Edinburgh: A. Fullarton, 1863), vol. 2, p. 319. Though, one author said that she never "obtained the influence which Lady Holland 
exercised in the Whig party. Soulbury "Women of Influence", p. 401 .

${ }^{34}$ Where "Grote in a great rage, [was] doubtless spurred on by Mrs. Grote." Ian Newbould, Whiggery and Reform, 18301841, (Stanford University Press, 1990), p. 190.

${ }^{35}$ Newbould, Whiggery and Reform, p. 203.

${ }^{36} \mathrm{~J}$. C. D. Clark, English Society, 1688-1932, (Cambridge University Press, 1985).

${ }^{37}$ Von Den Steinen, "Discovery," p. 247 note 2 .

${ }^{38}$ Ibid. , p. 230 .

${ }^{39}$ Ibid. , p. 246 .

${ }^{40}$ Colley, "Politics," p. 379.

${ }^{41}$ Lewis, "Political Behavior," p. 248.

${ }^{42}$ Ibid., p. 233.

${ }^{43}$ By members of my committee: Professors Ann Weikel, David Johnson, Susan Karant-Nunn, and Christine Thompson. 
CHAPTER II

POLITICAL HOSTESS

The role of political hostess was the most powerful that British aristocratic women played in British politics and society of the mid-eighteenth to mid-nineteenth century. Political hostesses determined the direction of politics by controlling who met whom and who discussed what. The contemporary nexus of politics and society depended upon and was established by the power of British aristocratic women.

Political hostesses created social events where politics was discussed and argued. Politicians created consensuses and tested the waters from the early days at Melbourne House to the later days at the homes of Lady Cowper and Lady Holland. At Melbourne House "politics were vehemently discussed" especially politics of the Fox-North Coalition, the Prince of Wales's allowance and debts, and the Westminster Election of $1784 .^{1}$ In 1808 Lord Grey said "Our dinner at Holland House was for the purpose of talking over Parliamentary business." ${ }^{2}$ During the decade of the 1830s when Lord Holland was a member of the Cabinet, the ministers met for dinner at Holland House almost weekly while Parliament was in session. The parliamentary session and the social season ran concurrently. 
There were two parts to the role of political hostess. First, was control of entertainment in one's own home, i.e. the establishment of a political salon. Second, and as important as the first, was the part of arbitrator, of determining who was accepted in aristocratic society where political policy was made. Both parts gave enormous power to British aristocratic women. Due to the close interconnection of politics and society during this time, to be accepted politically meant you also must first be accepted socially. Thus it was the political hostess who determined who was politically acceptable.

The power of a political hostess, however, is not easy to describe. "Of all powers, social influence is the most difficult to exercise, the most difficult to account for, and the most difficult to portray, because it is entirely a matter of impression." ${ }^{3}$ "While its political content is diffuse, it is nevertheless, quite real." ${ }^{4}$ It is a role contemporaries relied on and modern historians ignore, due to their lack of knowledge of the close interconnection between politics and society during this time period. The political hostess "held real power, although not necessarily overt power." She did far more than entertain for husband or father. Female political hostesses at the highest level of politics wielded more political power than male politicians at the lower levels." "These ladies had as much power as 
leaders of society that it was said they could even get an important debate postponed in the House if one of them had fixed a grand dinner on that evening. "7

Some British aristocratic women were so involved in the various aspects of political hostessing that contemporaries commented when they were not in London. In the summer of 1837, a time of good harvests, peace, and great promise for the Whigs, Melbourne quipped to Lord John Russell "Lady Holland is out of town. "8 Brougham believed that Lady Jersey was essential to the Whig party and when she was absent from London the party suffered.

Lady Jersey's absence is very bad for the party. She alone had the right notion of the thing, and her influence in society was always honestly and heartedly exerted with her usual excellence of disposition. Ill as we can spare speakers, we can still less afford such a loss as this.

When the salon was shut, politicians fretted. In 1783, during a time of delicate peace negotiations between France and Britain, Georgiana, Duchess of Devonshire, was pregnant with her first child (Little G). The French Ambassador was upset by the subsequent closing of Devonshire House, for he was accustomed to meet the elusive fox on a daily basis at Devonshire House. "Mr. Fox is careful to avoid every possible opportunity to talk to me, the House of the Duchess of Devonshire, where I usually meet him informally, has been closed to us all for three weeks." 10 
Some historians refer to British aristocratic women political hostesses as working behind the scenes. "Lady Melbourne was a potent influence behind the scenes of the twin London political theaters, the House of Commons and the House of Lords." However, during this time period it was not a matter of being behind the scenes but rather being a vital part of the scenes. This important difference was not lost to contemporaries who knew and valued the role of British aristocratic women as political hostesses. ${ }^{11}$

Breaking down the role of political hostess into three parts facilitates the understanding of their political role. First, British aristocratic women controlled who was and who was not invited to social and political events. British aristocratic women, in general, issued all invitations to events at the major political and social centers. Second, through their creation of common, neutral ground (as opposed to the partisan Houses of Parliament and the politically segregated men's clubs), political hostesses created a place where a wide variety of political views were aired and discussed, thus exposing party adherents to new political ideas. $^{12}$ Political hostess created the space where Tory X could meet whig $Y$, or where whig $X$ of one political faction could meet whig $Y$ of another political faction. Third, British aristocratic women political hostesses brought new blood into the political scene. They continually vetted and 
supported young British political talent and introduced foreign politicians to the British socio/political nexus.

One reason political hostesses were so powerful was that men liked to talk. This was not the age of discretion. Most men and women talked about politics at social events. There was a great blurring of political and social conversation; which was which was not clear cut. No one reading the diaries and letters of the time can fail to be struck by how indiscreetly male politicians talked. Even Madame de Lieven, accustomed as she was to indiscretions, remarked of Melbourne "he confides strange things, this minister."13 Lady Shelley in her diary revealed that Peel discussed the reconciliation of Plunkett and Castlereagh and additional inside information. "Peel has just told me the following story of Plunkett. I have just heard the following about Bonaparte." ${ }^{14}$ Political gossip got so bad Brougham proposed and Grey supported, a rule which forbade any cabinet minister going to a club. ${ }^{15}$ But no politician could stop politicians from going to social events.

Most of these social events were full of political gossip. Holland House was a hotbed of gossip; it had the reputation of having the loosest tongues wagging at its dinners. Government secrets were leaked at Holland House, many times by Lord and Lady Holland, and many times by their guests. ${ }^{16}$ The Prime Minister produced evidence that some 
account of the proceedings of the English cabinet was being conveyed to Paris and Vienna. It was said to be derived from Lord Holland himself. ${ }^{17}$ But Lady Holland and her husband were not the only indiscreet speakers.

Moreover, these loose tongues did serve a purpose-controlled leakage of governmental information.

Despite the reputation of Holland House as a source of leaks and indiscretions, it provided a useful service in supplementing formal diplomacy, and sometimes the leaks operated in the reverse directions for Palmerston's benefit.

In 1840, relations between France and Britain were strained. Holland House was the semi-official link between the two governments. The Whigs used Holland House to "assure the French that the whole Melbourne government was not in fact slipping into Tory attitudes." 19

Even Lord Melbourne, a harsh critic of Holland House leakages, agreed that there was little to be done about them. He told Lord Holland in 1840,

I know not what can be done except to take care that as little of political affairs transpires in conversation as possible. But this is inconsistent with a salon, which has many advantages but some disadvantages.

In 1833, Lady Holland's gossip caused Canning and Grey great distress over the recall of Prince Lieven, the Russian ambassador to Britain. It was Lady Holland who stated that Lieven was recalled due to Canning. Canning categorically denied this and wrote a letter to Lord Holland in which he 
criticized Lady Holland for "circulating the canard." This was not the first time, by any means that Grey and other members of the Government complained of "Lady Holland's croakings." 21

INVITATION CONTROL

Within the context of the close interconnection of politics and society, British aristocratic women controlled who was or who was not pelitically acceptable by controlling who was or was not socially acceptable. By controlling the invitation to social events, British aristocratic women controlled the when, where, and who of politics. The power to regulate questions of social mobility is a critical role. $^{22}$ Political hostesses controlled political policy by whom they did or did not invite to both general social events such as assemblies, balls, and breakfasts and also to smaller more political events such as dinners and weekends at country homes. Women controlled the invitations. "I went to Lord North's--or rather Lady North's--on Thursday evening." 23 As mentioned above, Lady Holland issued all the invitations to Holland House. Lord Holland never invited people without Lady Holland's permission and frequently came to his own table without knowing whom he would see. ${ }^{24}$ Lady Cowper wrote invitations to parties and dinners in her own hand. ${ }^{25}$ Lady Grey invited Palmerston to have Lord Grey talk over the 
possibility of a new diplomatic mission for her relative, Lord Durham. ${ }^{26}$

Almacks Assembly Rooms, the premier social gathering place in eighteenth-century England, was a good example of how British aristocratic women used a social event to control political policy. Established in 1765 and lasting until 1835, Almacks, almost from the start was controlled by a group of British aristocratic women with political interests. "The rules of admission made by the Ladies' Committee [patronesses] served to further political as well as social ends." 27 Many of the Almacks patronesses were known for their political power and influence such as Lady Cowper, Lady Jersey, Princess Lieven. From the start the patronesses made the club extremely exclusive. Only those approved by the Ladies Committee could enter the club. Without admittance to Almacks, men and women were not accepted into the highest level of British aristocratic society and therefore not admitted into the highest level of British political society. Women made political policy by whom they invited or did not invite. In 1827, Lady Cowper did not think it was wise for Lady Holland to invite O'Connell, the Irish politician, to her dinners at Holland House and she stopped Lady Holland from inviting Lansdowne to meet o'Connell. ${ }^{28}$ In 1858, politics and society was shaken by the India Mutinies. "But there was an easy feeling that "Lady Pam's [Lady Cowper] 
parties and the opening of Parliament" would mend it all. ${ }^{29}$ Lady Fanny Elliott, the new Lady John Russell, in 1841,

did hold some part of the fate of future whig ministries in her hands, for now that he was married again, Lord John, would be expected to entertain. [However] she could never rise to the role of a political hostess. ${ }^{30}$

She refused to give political dinners for anyone, even Lady Holland (a very close friend and mentor of her husband as well as a powerful political hostess).

British aristocratic women issued invitations for political purposes. During the Fox-North Coalition days, Georgiana opened the doors of Devonshire House to all who supported the coalition. Lady Hester Stanhope, the niece of William Pitt the Younger, controlled invitations to meet him while he was the prime minster. From this base as political hostess she wielded great power, especially with Canning. "Lady Hester Stanhope keeps Mr. Pitt's house, and Canning uses her influence also to maintain his own." ${ }^{31}$ In 1832, Lady Jersey invited a variety of politicians to a meeting of Ultra-Tories to help reinforce the Duke of Wellington's political power. ${ }^{32}$ The women in Lord Morpeth's family invited the families and friends of the Irish members because Lord Morpeth was the Chief secretary for Ireland. ${ }^{33}$ Lady Cowper did not invite those who voted against Palmerston in Parliament, even if they were of his own party. ${ }^{34}$ Emily Eden, the sister of George Eden, the second Lord Auckland and 
First Lord of the Admiralty (1834-35), set up her salon to be a place where government ministers met.

I have been very busy this last week setting up house, as the Ministers will be most of them in town without their families and George [her brother] has announced an intention to make the admiralty pleasant to his colleagues.

She was in the thick of things. "Ours is the only official home left open. They have dined here most days and several others came in, in the evening. "36

In January 1816, Lady Melbourne got Huskisson and Palmerston together for dinner at Melbourne House. This was the first sign of closer ties between the two warring faction leaders who did not like each other. This dinner meeting was the idea of Lady Cowper, who then persuaded her mother, Lady Melbourne, to put up the prestige of Melbourne House. "Probably this was one of the first political contributions made by Lady Cowper." ${ }^{37}$ This meeting was made easier for Lady Cowper to arrange because of the family ties she had with her cousin Mrs. Huskisson, again revealing the close ties between society and politics during this time period. Indeed, whenever Palmerston lost political support for his stands on issues, Lady Cowper would organize a dinner (or other social function) for potential supporters and waverers to mingle. She wrote "We have been giving some dinner and evening parties which have had a very good political effect, 
have helped the party, and have pleased many individuals belonging to it." ${ }^{38}$

Many times the privilege of being invited to one of the political salons was extended for politicai reasons to people of the middle class. In 1819 Lady Holland gave a dinner party at Holland House for the Whig parliamentary lawyers and their wives and daughters. Lady Shelley described these dinner guests in her diary as "a comical set that looked completely out of it in the society of Lady Cowper, Mrs. George Lamb, etc." ${ }^{39}$ Lady Cowper might have been a stern, social stickler as an Almacks' patroness, but she opened her doors at Cambridge House, Picadilly, to a "doubtful voter who was thus allowed to enter into society. "40

British aristocratic women controlled invitations to effect political decisions. In 1819, Lady Jersey manipulated the invitation to a dinner party in order to bring Brougham and a foreign diplomat together. The inestimable Mr. Creevey described the situation.

There is the devil to do about Lady Jersey wanting to get Brougham not to dine there but to dine without her to meet Prince d'Aremberg, who wants particularly to meet Brougham. The latter tells Lady Jersey that as Mrs. Brougham dines at Lord King's, he can't let her go there."

The most obvious example of a woman exerting control over invitations was Mrs. Arbuthnot. She vetted every invitation for her friend, the Duke of Wellington. She 
stated in 1830, "I went the night before last to a ball at the Princess Lieven's. But I prevailed on the Duke not to go for her impertinence really enrages me." ${ }^{42}$ Mrs. Arbuthnot was his hostess in both London and at his country estate, Stratfield saye. She issued the invitations and controlled which events he attended. ${ }^{43}$

\section{CREATION OF NEUTRAL GROUND}

People with different political opinions were not necessarily excluded from social/political events. Under Georgiana's sway Devonshire House, opened its doors to "politicians, princes, poets, artists, authors, gentlemen of wit, ladies of fashion, all the thousands personalities all met on common ground." 44 Holland House, the home of the staunch Foxite Whigs, "always more or less was neutral ground, even when Lord Holland was himself a member of the Government." 45 To the successful political hostesses, party was not necessarily the most important characteristic in determining whom to invite. Tories frequently dined at Holland House. Lord Holland wrote to his sister, Caroline Fox, in 1837 and said, "We have Tory dinners, diplomatic dinners, and family dinners." ${ }^{46}$ Lady Rosebery, like Lady Holland and other great political hostesses "believed in bringing together in social intercourse men of widely divergent views." ${ }^{47}$ Even the staunch Tory, Mrs. Arbuthnot, 
was invited to parties with staunch Whigs. She reported in a letter "I went to Madame de Lieven's. She had all the bad company, such as the Hollands, Mr. Huskisson, and that lot. $" 48$

Political hostesses created neutral ground where people could meet people they would or could not meet in normal circumstances. Although Lady Cowper's salon was the headquarters of the Liberal Party, she invited members of all political parties and many foreigners. A French diplomat told Disraeli at one of Lady Cowper's receptions,

What a wonderful system of society you have in England. I have not been on speaking terms with Lord Palmerston for three weeks and yet here I am. But you see I am paying a visit to Lady Palmerston.

Common ground was especially important for issues like the Reform Bill of 1832, which needed both a wide consensus and continual soothing and massaging in order to pass. Both political parties, Whig and Tory (and all their factions), used social events to reach a party-wide consensus about the Reform Bill. Political hostesses were extremely valuable in providing places where the issues could be discussed and aired in a relatively non-threatening way. Holland House played an extremely important role in the passage of the Bill. Lady Holland provided a place where the aristocrats and middle class could meet, discuss common needs, and reinforce each other concerning the complex issues involved 
in the measure. ${ }^{50}$ Lady Cowper gathered around her an "assortment of characters" who fought against the Reform Bill of 1832. ${ }^{51}$ The author further stated that Lady Cowper's coterie in the 1830 s was a "foppish, languid damper on the progressive aspirations of Whigs and Liberals." 52

Other political hostesses gathered together people who could support an issue. In the 1820s during the struggle for religious rights, Holland House was a refuge for dissent.

Lady Holland commented,

This House is filled in the morning with Jews and

Dissenters, people of all persuasions, even up to the Archbishop of York, to whom I sent Mary (her daughter) in the Library to amuse him until Papa get off some Secretaries.

Between the end of the Peninsula war in 1815 and the actual passage of the Reform Bill in 1832, "all the Whig ladies were trying to capture the young men for their side." 54

\section{VETTING OF NEW POLITICAL TALENT}

One aspect of the role of political hostesses that brought British aristocratic women much power and influence was their vetting and sponsoring of young men. Gordon House, Melbourne House, Devonshire House, Holland House, and Panshanger were all places where young political talent was developed. Sheridan, Grey, Melbourne, Lord William Russell, Macaulay, Granville, Brougham, and Canning were only a few of the politicians who got their start because of one of the 
great political hostesses of their day. One did not necessarily need a pedigree to succeed at Holland House or other Whig political salons. "Clever repartee was necessary for one to succeed at Holland House," along with wit and political ability. ${ }^{55}$

Lady Holland collected a "whole clique of young men." 56 She stood watch over and trained the next generation of young politicians by politicizing and socializing the "Grand Whiggery's young ones." ${ }^{57}$ Lady Holland supported the young sons of the 6th Duke of Bedford, William and John Russell. She saw to their social and political education. She brought them with her on her travels and stays abroad, introducing them to the people and places useful for their political future. Lord William was perhaps her most important protegee. She passed the tenets of Foxite Whiggism on to the next generation through him. ${ }^{58}$

Lady Cowper gave parties for Palmerston and collected young supporters who would throw their support behind Palmerston. Young Whigs were educated at Chatsworth, Woburn, and Holland House--the country estates of the great Whigs Cavendishes, Russells, and Foxes. Lady Holland described Lord Grey as being drawn into whig circles by "fashion. . . all the beauty and wit of London. . . and the seduction of Devonshire House." ${ }^{59}$ Georgiana, the Duchess of Devonshire, invited the young hopes of the Tory party such as Canning, 
Hawkesbury, and Castlereagh. ${ }^{60}$ Georgiana also took the young Lord Grey under her wing (and thus also into the Whig Party). At age 22 he made his maiden speech in the House of Commons, with Georgiana's assistance and support. Georgiana's favoring of Grey did nothing to "diminish his standing in the [Whig] Party." Even after their personal relationship blossomed and cooled, Grey continued to come to Devonshire House with his political cronies. ${ }^{61}$ Georgiana also introduced Sheridan into the whig Party. She brought him into Parliament in 1780 by securing a Spencer seat for him at Stafford. He sat for the borough for over 20 years. Lewis believed Georgiana's support for Sheridan was "substantial and could not have carried more weight had she been a man." 62 The women of Devonshire House also united the Tory politician Lord Granville Levinson-Gower to the Whig party. Lord Granville was raised in strict Tory circles. His best friend was the Tory politician George Canning and his godfather was the Tory Prime Minister William Pitt. ${ }^{63}$ However, he became a long time friend and lover of Lady Bessborough, sister of Georgiana, Duchess of Devonshire (and eventually married Harriet, the daughter of Georgiana). He stood for Parliament as a supporter of Pitt but the evenings he spent at Devonshire House, under the sway of the Whigs. Lady Bessborough, Georgiana's sister, furthered Granville's career by promoting her own political opinions to Lord 
Grey. ${ }^{64}$ Mrs. Crewe saw to the political launching of Canning and Wilberforce. ${ }^{65}$

\section{INDIVIDUAL POLITICAL HOSTESSES}

Many British aristocratic women were political hostesses in the sense that they determined the direction of politics by controlling who met whom and who discussed what. In this section of this chapter I am going to discuss the activities (invitation control, creation of neutral ground, and the vetting of new politicians) of the major political hostesses in chronological order--Lady Melbourne, Georgiana, Jane, Duchess of Gordon, Lady Holland, and Lady Cowper. Through a brief study of the activities of these women, we can gain a clearer insight into the role of political hostess as a whole.

Elizabeth, Lady Melbourne, created a political salon at Melbourne House soon after her marriage and arrival in London in 1769. Her life revolved around the political activities of the time. Melbourne House, her home in Westminster, was "open house to the Prime Minister and other statesmen." 66 For many years she controlled access to the Prince of wales by determining who was invited to meet him at various social events. Lady Milbanke, her sister-in-law, distanced herself from Lady Melbourne, owing to Lady Melbourne's affair with the Prince of Wales. But Sir Ralph Milbanke, Elizabeth's brother regretted the breach because it denied him access to 
the political power at Melbourne House; Lady Melbourne was important to his political and social career. He continued to keep in touch with his sister and eventually forced his wife to make up the quarrel. ${ }^{67}$ The innermost whig political aristocracy (of Fox, Prince of Wales, Windham, Canning, and Sheridan) was under the control of Lady Melbourne.

Why did Lady Melbourne have a political salon, rather than a merely social salon (to the extent that any event during this time could be social and not political)? I believe there were two reasons. First, she was not of the highest social rank prior to her marriage. To some extent she was a self-made aristocrat. She knew she could not immediately make a purely social impact in aristocratic London society, so she used one of her best skills, politics, as a way to become accepted in the highest circles. Second, Lady Melbourne was genuinely interested in politics. She came from a regional family that had been active in county politics for generations. Lady Melbourne schooled young men in political matters, and most of the young politicians who rose to prominence during this time were tutored and supported by Lady Melbourne. In 1808, Sir John Moore, a celebrated general in the Peninsula War, wrote a letter to Lady Melbourne. In it he tweaked her by urging her to "undertake the patronage of a school for the education of all future Ministers of War, the Colonies, and of Foreign 
Affairs."68 Lady Melbourne "combined charm and intelligence with exquisite tact and few scruples, and she was indeed as perfect a hostess as her friend Madame Recamier. "69

Georgiana, the Duchess of Devonshire, like Lady Melbourne, began to act as a political hostess shortly after her marriage in 1774. Even during her honeymoon she oversaw political meetings with Charles James Fox and others. In January 1775, she established her political salon in London at Devonshire House. Within a year of her marriage, Georgiana was the "queen of the Whigs." ${ }^{70}$ Devonshire House had not had a hostess for twenty-one years. It was up to Georgiana to set the political and social tone of her family, the house, and her political party. She occupied a position only just slightly below that of royalty. ${ }^{71}$

Jane, the Duchess of Gordon, was the most prominent political hostess of the early period studied in this thesis. She was a leader of fashion in her day and a "person of no slight political importance." ${ }^{22}$ At her house in Pall Mall, she received large gatherings of the hangers-on of the Tory government during the last fourteen years of Pitt's first administration (1787-1801). ${ }^{73}$ She also supported her fellow Scots politicians Dundas and Aberdeen. George Canning noted in his diary the many times he went to her house to discuss politics. ${ }^{74}$ She was known as Pitt's confidant. ${ }^{75}$ 
Lady Holland was perhaps the archetypical political hostess of this time period. There were political hostesses before her, such as Lady Melbourne, Georgiana, and Jane, Duchess of Gordon and after her, such as Lady Cowper and Emily Eden, but Elizabeth, Lady Holland, was the epitome of political hostesshood with her "mix of high life and political enthusiasm." ${ }^{76}$ Holland House succeeded the power of Devonshire House. ${ }^{77}$ Lady Holland's power was great. She was "the only really undisputed monarch in Europe. "78

Lady Holland was the exception to the rule that political hostesses were social arbitrators. Because of her divorce (from her first husband, Sir Godfrey Webster) and remarriage to Lord Holland, Lady Holland was socially unacceptable to some, especially women, for the rest of her Iife. ${ }^{79}$ Though, as time went by, society gradually accepted her.

Through virtue of her husband's position as a near relation of Fox (his nephew), she endeavored to exert an influence on the whig Party, but was handicapped by the fact that the great Whig ladies so far refused to visit her. ${ }^{80}$

This was true on one level. The great Whig ladies were slow to accept her socially. But this did not hurt Lady Holland's political power. If the ladies did not come to Holland House their men did. ${ }^{81}$

However, regardless of the fact that she may have been socially unacceptable to many, Lady Holland was accepted 
politically from the start of her marriage to Lord Holland. Both the Whig Party and Lord Holland needed a political hostess. And they could not have gotten a better one, one more suited to maintaining the outsider image of the Whigs, as they were out of office for many decades. Lady Holland just created her own circle, the most powerful one of her time. She rarely went out into society, even in later years. Everyone came to her. She overcame her social handicap by creating the quintessential political salon of the early nineteenth-century. In spite of the divorce, the Hollands were able to gather around them a coterie of social, literary, and political talent, which in the "annals of this country (England) has never been equalled." ${ }^{82}$ Even in the off season, Holland House was the place to meet. ${ }^{83}$

In many ways, Lady Holland was a throwback to the early bluestocking salons of the eighteenth-century. Like Mrs. Elizabeth Montagu and Mrs. Vesey, she controlled the conversation by deciding the topics of discussion and where people were to be seated as well as who was invited. She was famous for the "exquisite art with which she directed and controlled the scene." ${ }^{84}$ Henry Holland, M.D., (not a relation) was a friend of the Hollands for thirty years. He best described Lady Holland and captured this quality of character. She was 
supreme in her own mansion and family, she exercised a singular and seemingly capricious tyranny even over guests of the highest rank and position. Capricious it seemed, but there was in reality intention in all she did; and this intention was the maintenance of power, which she gained and strenuously used, though not without discretion in fixing its limits. No one knew better when to change her mood, and to soothe by kind and flattering words the provocation she had just given, and was very apt to give again. Her management of conversation at the dinner table-sometimes arbitrary and in rude arrest of others, sometimes courteously inviting the subject-furnished a study in itself. Every guest felt her presence, and generally more or less succumbed to it.

Part of the allure of the famous political hostesses was their informality. Lady Holland used an informal style to politically manipulate her guests. Tom Moore discussed a typical event at Holland House. In 1834, he described the Chancellor (Brougham) in a black frock coat and black cravat stretched out on the sofa. The Prime Minster in the same attire was also stretched out with his legs cocked up on a chair. Lord Holland talked to the Prime Minister and Chancellor while Lady Holland was in a corner with Talleyrand, the French Ambassador, discussing a book "in case he (Talleyrand) might otherwise pay too much attention to this impromptu cabinet committee. "86

Lady Holland was also similar to the famous French political hostesses. She was the "only British Hostess in history comparable to Madame de Ramboullet." ${ }^{87}$ For the aspiring poet or politician, Holland House, "in true salon 
style, was the entree to a career." ${ }^{88}$ However, none of the bluestocking salons leaders had more than a dash of Lady Holland's style. She had her "own peculiar style of discussion, her breathtaking effrontery, her tantrums, and her calculated capriciousness." ${ }^{89}$ "All found the atmosphere of Holland House irresistible in spite of the domineering habits and tactics of their hostess." ${ }^{90}$ However, there was no reason why a salon had to be comfortable place. "Some kinds of talent had to be cossetted, but most responded to provocation. " 91

There was, and is, great debate concerning the character of Lady Holland. She was a difficult person for her contemporaries to understand and she has been a difficult subject to study for subsequent historians. "To most of her guests, Lady Holland must have proved somewhat of an enigma, wielding as she did an extraordinary influence combined with capriciousness." ${ }^{92}$ Many historians believe her to be a domineering meddler in politics who controlled her husband according to whim and that the only reason people came to Holland House was to see Lord Holland. Fanny Kemble said it was only Lord Holland who kept Holland House alive. But Fanny Kemble did not like Lady Holland. ${ }^{93}$ Neither did Joseph Jekyll and Thomas Creevey whose diaries have been used extensively by historians. Lord Ilchester, editor of the history of Holland House, stated that Lord Holland was the 
"real cornerstone of the edifice" and Lady Holland was too autocratic and ruled with a "tyranny of fear." Yet Lord Ilchester was the descendant of Lord Holland. ${ }^{94}$

In many ways she was not the typical political hostess. She was not acceptable socially because of her divorce, she had a strong personality, and yet people kept coming to her home. Not everyone could stand Lady Holland. Lord Melbourne avoided Holland House for long time period. He said he did not like her and it was too uncomfortable. But he came back. ${ }^{95}$ People came to Holland House invited by Lady Holland. She created a place where "one hears about all that is going on about which she (Lady Holland) knows nothing and everything. " 96

Lady Holland created neutral ground at Holland House. She equally dominated Sheridan, Grey, Canning, Brougham, Melbourne, and the Russells. Lady Holland did not allow fierce philippics or ribaldry against political opponents at Holland House. ${ }^{97}$ Members who quarrelled in the House of Commons became reconciled at her suppers.

The salon in Kensington became a world-wide tradition; so much that an introduction to that holy of holies of the Whig Party was one which every foreigner on his arrival in England sought and prized.

one of Lady Holland's last actions before her death was to introduce Palmerston to Thiers. ${ }^{99}$ 
Lady Holland vetted young political talent. Lord Granville's younger son, Frederick Levinson-Gower, was one of her protegees. His mother did not like Lady Holland however. But Lord Granville, knowing the importance of the sponsorship of Lady Holland, allowed his son to be sponsored by Lady Holland. In 1829, Lord Grey also brought his son to Holland House to be sponsored. ${ }^{100}$

Lady Holland in 1834, supported the newly elected MP, Thomas B. (Tom) Macaulay. "Macaulay, although lacking the advantages of aristocratic birth or even of good looks, became a cherished member of the Holland House circle" and therefore supported in his political and literary career. ${ }^{101}$ In a letter to his sister, Hannah, in 1831, Tom Macaulay described one aspect of Lady Holland's support - that of supporting his novice speech in Parliament. Lady Holland arrived and "told me in her imperial, decisive manner that she had talked with all the principle men on our side about my speech" and that they all thought it was great. ${ }^{102}$

Lady Holland was an early supporter of the young William Lamb, later Lord Melbourne. In 1812, with his political career on a downward spiral after election defeats, Lady Holland wrote to his mother, Lady Melbourne, asking if she, Lady Holland, could help him. ${ }^{103}$ Lord Normanby was another Lady Holland protegee. Although he was heir to the Tory Earl of Mulgrave, he joined the Holland House set. ${ }^{104} \mathrm{He}$ 
entered Parliament at age 21 in 1818 and Lady Holland was there to support him--by vetting his speeches and soliciting people to think kindly of him. When Lady Holland took Canning into favor, this upset the Foxite branch of the Whig Party. To some degree by this support of Canning, she forced an alliance between Brougham and Grey who both "feared that an alliance with Canning would mean subjection to Canning."105 Emily, Lady Cowper, was a true daughter of the great Lady Melbourne. By 1805 and her marriage to Lord Cowper, she was a leading political hostess. At first she was a fierce supporter of her brothers (William, George, and Frederick Lamb) and of Whig party issues in general. By the mid to late 1820s she began to be politically active for her lover (later husband), Lord Palmerston. She acted informally as his political hostess as well as an intermediary between this somewhat Toryish politician and the Whig party, of which she was a leading light. She drew him into the whig world socially and politically. She

introduced him to a fantastic world of fashion, intrigue, and politics, far different from the bucolic quiet of Broadlands or the Tory dullness of his youth. For Lady Cowper was one of the queens of London Society and a leading member of the international set.

She saved him from "social suffocation among the Tories."107

In 1839, after an affair of almost thirty years and the death of Lord Cowper, Lady Cowper married Lord Palmerston. 
They were both in their fifties. She became the leading political hostess of the day.

This was a new role [political wife] for her but by no means a different role to play. she had always been a political woman and even by the 1820 s she was meddling in Palmerston's affairs as much as her brothers.

Pam (Lord Palmerston's popular nickname) now had a political hostess who could "make adherents for him. Marriage gave him new power."109 Lady Cowper gave him an entry into the political/social parties and entertainment and closer access to Queen Victoria.

We can see the political power and influence Lady Cowper brought to her marriage with Lord Palmerston by studying the first two weeks of their marriage. Two days after their wedding, Lady Cowper was entertaining envoys from Metternich. She was able, even though on her honeymoon, to provide a place where negotiations could take place. It was due to her success as a political hostess that the negotiations were successful. Though she later confessed that "while she had defended him so vigorously over the dinner-tables, her heart had quaked." ${ }^{110}$ Lady Cowper was a "fierce and energetic propagandist" and rarely had he needed one more than in his first year of married life (to Lady Cowper). ${ }^{111}$ He was staking his career on his view of the Eastern Question (the relationship of Britain with Russia and Austria). Now he had access to information and influence 
that before his marriage to Lady Cowper was not available to him. ${ }^{112}$ This is what Lord Holland meant when he said that he was looking forward to Lady Cowper's marriage to Lord Palmerston. Holland believed the marriage would help Palmerston by "softening him up and by bringing him a hostess to the Foreign office thus making him more accessible to diplomats and travellers." 113

Lady Cowper brought Lord Palmerston contact with the international set of which she had been a leading light for decades. She controlled the access of foreign travellers and diplomats to Palmerston. After her marriage to Palmerston, they rented a London house in Carlton House Terrace as "more suitable than that in stanhope street for Lady Palmerston's renewed career as political hostess."114 Lady Cowper gave Lord Palmerston the "matchless gift of a happy private basis for public activities the asset of a notable political salon."115 Her political salon had "undoubtedly been a considerable factor in the ultimate success of Lord Palmerston over Lord John Russell in the battle for the leadership of the Liberal Party." ${ }^{116}$ They lived more and more in London where Lady Cowper could "keep in touch with politics and pursue more successfully and undeviatingly the path she had chosen." ${ }^{117}$ When not in London, Lady Cowper was not happy. Emily Eden described a dinner at Panshanger, the Lamb country estate. "We dined at Panshanger yesterday. 
Lady Cowper is miserable at being out of all the ferment of London. " 118

At Panshanger, Lady Cowper was above party. She invited people from all political persuasions. She herself saw this as valuable and felt sorry for those who were not so broad minded, as she perceived Lady Holland to be. That Lady Holland had "the same political set at dinner every day must be tiresome in the long run."119 This was Lady Cowper's perception. Holland House did have its regular attendees. But Lady Holland also invited people from all political persuasions. Indeed the fame of Holland House rests on the variety of its attendees.

The power of political hostesses was enduring--through the lifetime of the individual hostess and sometimes through generations of British aristocratic women. However, many historians believed the political power of women was ephemeral and short-lasting. ${ }^{120}$ For example, one historian stated that Georgiana's participation in politics ceased with her campaigning in the 1784 Westminster election. ${ }^{121}$ But with a close study of her role as a political hostess, one can see the invalidity of this statement. Many British aristocratic women were politically active throughout their lives. They did not cease to be politically powerful as their youth fled. Childbirth, family relations, love affairs, and illnesses did not diminish their political influence. 
Georgiana created a political salon that continued for over fifty years, well beyond her death in 1806 . It continued through her successor, Lady Elizabeth Foster (the second wife of the 5th Duke of Devonshire) and through Georgiana's daughters Harriet and Georgiana, and Georgiana's granddaughters. Georgiana was ill for the last decade of her life, but she still entertained the Prince of Wales and other Whig leaders almost daily. As late as 1800, Georgiana gave a ball at Devonshire House to welcome a foreign diplomat. Over 800 guests attended. In February 1806, two months before her death, she gave an important assembly and supper for the members of the new administration, the Ministry of All the Talents. ${ }^{122}$ During the reign of Elizabeth Foster, the second wife of the 5 th Duke Devonshire, as with Georgiana "an invitation to the mansion was coveted and struggled for."123

The political salon of Lady Melbourne also lasted for over fifty years from about 1769 until her death in 1822. In many ways this salon was continued through her daughter, Lady Cowper. Lady Cowper's political salon and political power lasted from the time she was eighteen until her death when she was in her $80 \mathrm{~s}$.

Nor did political hostesses lose their political power with the death of their husbands. Even as widows, British aristocratic women continued to wield political influence. After Lord Holland's death in 1840, Lady Holland continued to 
be a powerful political hostess until her own death five years later. She continued to entertain, introduce and vet new political talent, and maintain neutral ground where politics of many different views were discussed. ${ }^{124}$ while she only rarely entertained at Holland House itself, Lady Holland continued to hold her political salon in London at her South Street address. As mentioned earlier, one of her last dinners in October 1845 introduced Palmerston to Thiers. "Her table smothered the angry feelings generated by prior diplomacy" of the two politicians. ${ }^{125}$ It was only with the death of Lady Holland that the political salon of Holland House ended. Lord William Russell described the impact of her death as "the end of the famous Holland House society, the most brilliant seen in London." ${ }^{26}$ Charles Greville in his journal also realized the importance of Lady Holland.

The world never has seen and never will again see anything like Holland House. Though it was by no means the same thing as it was during Lord Holland's life, Lady Holland contrived to assemble round her to the last a great society, comprising almost everybody that was conspicuous, remarkable, and agreeable.

Nevertheless, some historians believed the political power of British aristocratic women ceased with the death of their husbands. One author stated that Elizabeth Foster "recognized the end of her career as an active force in the political life of her time. As a Dowager Duchess her reign was shorn of all its glory." ${ }^{128}$ This was not true. Elizabeth 
Foster continued to have a successful and important political salon after the death of the 5 th Duke.

\section{Comparison to French Salons}

How did the British political salons develop, how were they related to the British literary salons of the Bluestockings, and what similar characteristics did they have with the contemporary French salonists? The British political salons developed along with and were a necessary component of the nexus of politics and society of the period. The political salons served as alternative seats of political power, especially for the'Whigs, who were to begin a thirty year hiatus from power. The real question was how and why British aristocratic women (and not men) were in charge of the major political salons? One explanation could be the dual influence of the British literary salon and the French salonists.

The British political salon of the mid-eighteenth to mid-nineteenth century differed a great deal from the British literary salons of the second half of the eighteenth century. The latter did not usually have politics as its main focus. The literary salon was also more middle class than the aristocratic political salon. The British literary salons began about 1750 with Lady Mary Wortley Montagu. Other British literary salonists included Fanny Burney, Elizabeth 
Vesey, Elizabeth Carter, Elizabeth Montagu, Mary Granville Delany, Hester Mulso Chapone. The classical French and British salonists orchestrated the conversation "with wit and brilliance." ${ }^{129}$ The literary salonists prided themselves on their graceful informality which gave rise to the name of their group the Bluestockings. ${ }^{130}$

The salons of the great political hostesses continued some elements of the literary salons. Some political hostesses introduced emergent and fledgling literary as well as political figures to society. Lady Holland was perhaps the most adept at mixing art, literature, and politics in one great salon.

It was precisely in this diversity of topic and personality that the salon as a species of social life took root and flourished. Holland House society represented a self-conscious attempt to bring the powerful and best together for their mutual edification and enjoyment.

Many of the British aristocratic women active in politics were themselves daughters of literary salonists. These included Georgiana and Mrs. Crewe. And some literary salonists participated in politics, such as Fanny Burney, and Hester Chapone.

The French salonists were "witty, independent, powerful, well-read and sometimes libertine."132 The salons became the base for "influential women who swayed kings, governments, political opinion, and literary and artistic 
taste."133 They provided a voice for views not necessarily welcome at court. They differed greatly from the British literary salons. They were always more political and more aristocratic. Mostly males attended the French salons, while the British literary salons attracted people from both sexes. In France

the salon allowed both women and men a social mobility which existed no where else. The salon mixed elements of the nobility, bourgeoisie, and intelligentsia and enabled some women to rise through both marriage and influence.

The British political salon mixed elements of the above. Like both types of other salons, its leaders were women, mainly aristocratic women. Like the French salon, politics was the main emphasis. Similar to the salonists, British political hostesses served as a clearinghouse of news and ideas. ${ }^{135}$ Like the British literary salons, both men and women attended the salons (though Holland House was an exception to this). Both sexes attended the political salons.

\section{CONCLUSION}

The role of political hostess was the most powerful role British aristocratic women played in the nexus of British politics and society of the mid-eighteenth to midnineteenth century. Political hostesses determined the direction of politics by controlling who met whom and who 
discussed what. The contemporary nexus of politics and society depended upon and was established by the power of British aristocratic women. Without the power of the political hostesses the political and social system would have collapsed. Social events were places where politics were discussed, argued. Politicians created consensus and tested the waters from the early days at Melbourne House to the later days at the homes of Lady Cowper and Lady Holland. However, the power of a political hostess is not easy to describe. It is a role that contemporaries relied on and modern historians ignore, due to their lack of knowledge of the close interconnection between politics and society during this time period.

There were three major aspects of political hostessing (invitation control, creation of neutral ground, and the vetting of political talent) that illustrate British aristocratic women's great political power and influence. British aristocratic women issued invitations for political purposes and controlled invitations to effect political decisions. Political hostesses created neutral ground where people could meet people they would or could not meet in normal circumstances. Common ground was especially important for issues like the Reform Bill which needed both a wide consensus and continual soothing and massaging in order to pass. Political hostesses were extremely valuable in 
providing places where the issues could be discussed and aired in a relatively non-threatening way. In many ways it was the role of political hostess to gather together people who could support an issue.

One aspect of the role of political hostesses that brought British aristocratic women much power and influence was their vetting and sponsoring of young men. Gordon House, Melbourne House, Devonshire House, Holland House, and Panshanger were all places where young political talent was developed. Sheridan, Grey, Melbourne, Lord William Russell, Macaulay, Granville, Brougham, and Canning were only a few of the politicians who got their start by one of the great political hostesses of their day.

The British political salons developed along with and were a necessary component of the nexus of politics and society of the period. The political salons served as alternative seats of political power, especially for the Whigs, who were to begin a thirty year hiatus from power. The real question was how and why British aristocratic women (and not men) were in charge of the major political salons? One explanation could be the dual influence of the British literary salon and the French salonists.

The British political salon mixed elements of the above. Like both types of other salons, its leaders were women, mainly aristocratic women. Like the French salon, 
politics was the main emphasis. Similar to the French salonists, British political hostesses served as a clearinghouse of news and ideas. Like the British Iiterary salons, both men and women attended the salons.

In many ways the most familiar role of women in politics is that of a political hostess. We have probably heard of the bluestockings, and perhaps one of the British political salonists, such as Lady Holland. This role vaguely conforms to our comfort level of what we deem appropriate for women and politics. Through the information presented above, I hope the readers can see that a political hostess was more than that, and that they can see the fundamental value and unique role of British aristocratic women in the sociopolitical life of the time. 
ENDNOTES FOR CHAPTER II

${ }^{1}$ Sheila Berry Smith, Countess of Birkenhead, Peace in Picadilly: The Story of Albany (New York: Reynal, 1958), p. 26.

${ }^{2}$ G. M. Trevelyan, Lord Grey of the Reform Bill: The Life of Charles, Second Earl Grey, 2nd ed. (London: Longmans, Green, 1929), p. 166 .

${ }^{3}$ George Leveson Gower Granville, The Iife of George Leveson Gower Second Earl Granville, 1815-1891, 2 vol., 3rd ed., edited by Edmond George Petty Fitzmaurice (London: Williams \& Norgate, 1952), 2:126.

"Lewis, "political Behavior", p. 256.

${ }^{5}$ Melville E. Currell, Political women (London: Croom Held, 1974), p. 14.

${ }^{6} \mathrm{D}$. J. V. Jones, "Women and Chartism," History 68 (1983): 78 .

${ }^{7}$ Elizabeth Lee, Wives of Prime Ministers, 1844-1906 with contributions by Mrs. C. F. G. Masterman (London: Nisbet, 1918), p. 101. Refers to Lady Palmerston, Lady Tankerville, and Lady William Russell. Both Lady Holland and Georgiana manipulated the dinner hour to suit their own social/political style. Georgiana decided that the dinner hour should be about $10 \mathrm{pm}$ which therefore pushed the time of Parliament sitting until late after dinner. Thus Georgiana got the whole time of parliament sitting to follow her decision of when dinner should be. During the social and political season when all were in London and Parliament was in session, life switched to these late hours all due to Georgiana's power. Lady Holland however, made it fashionable for dining at $5 \mathrm{pm}$ at Holland House. "Her power over society was sufficient to compel people to get to her house at that hour." John Fyvie, Notable Dames and Notable Men of the Georgian Era (London: Constable, 1910), p. 180.

${ }^{8}$ Ian Newbould, Whiggery and Reform 1830-41: The Politics of Government (Stanford, CA: Stanford University Press, 1990), p. 210.

${ }^{9}$ Brougham to Creevey 14 Nov 1816 quoted in Lewis, "Political Behavior", p. 259-260.

${ }^{10}$ Masters, Georgiana, p. 200. 
${ }^{11}$ Margot Strickland, The Byron women (New York: St. Martin's, 1974), p. 82 .

${ }^{12}$ There were two famous men's clubs in London. Brooks, established in 1764, was for Whigs, and Whites, established in 1698, was for Tories, Bessborough, Lady Bessborough and Her Family Circle, p. 47. 1958), p. 240 .

${ }^{13}$ Frances Hawes, Henry Brougham (New York: St Martin's,

${ }^{14}$ Frances Shelley, The Diary of Frances, Lady Shelley, ed. Richard Edgecumbe, 3 vols. (London: J. Murray, 1912, 1913), $2: 91$.

${ }^{15}$ Hawes, Henry Brougham, p. 241.

${ }^{16}$ Both Hollands repeated "every Cabinet secret at their parties at Holland House, even when the French Ambassador was present." Lord David Cecil, Melbourne (Indianapolis: Bobbs Merrill, 1954), p. 398.

${ }^{17}$ Giles Stephen Holland Fox-Strangeways, Sixth Earl of Ilchester, Chronicles of Holland House, 1820-1900 (London: John Murray, 1946), p. 282.

${ }^{18}$ E. Anthony Smith, Lord Grey, 1764-1845 (Oxford: Clarendon, 1960), p. 283.

${ }^{19}$ Mitchell, Holland House, p. 299.

${ }^{20}$ Ilchester, Chronicles, p. 282.

${ }^{21}$ Ibid., p. 180. This political crisis began with Grey however. He appointed his cousin stratford Canning as ambassador to St. Petersburg. Russia did not approve of stratford and would not accept him. Palmerston refused to change the appointment and Russia recalled Lieven, their ambassador.

${ }^{22}$ Lewis, "Political Behavior", p. 256.
${ }^{23}$ June 1788, Gilbert Elliot, The Life and Letters of Sir Gilbert Elliot, First Earl of Minto From 1751-1806, ed. Emma Eleanor Elliot-Murray-Kynynmound, Countess of Minto, 3 vols. (London: Longmans, Green, 1874), 1:235.

${ }^{24}$ Recollections of the Table Talk of Samuel Rogers (1856) p. 275, quoted in Fyvie, Notable Dames, p. 179.

${ }^{25}$ Lee, Wives, p. 121. 
${ }^{26}$ Kenneth Bourne, Palmerston: The Early Years $1784-1841$
(New York: Macmillan, 1982), p. 530 .

${ }^{27}$ Mabell Frances Elizabeth Gore Ogilvy, Countess of Airlie, Lady Palmerston \& Her Times, 2 vols. (London: Hodder \& Stroughton, 1922), 1:40. Others included Lady Castlereagh, Mrs. Drummond Burrell, Lady Sefton, Princess Esterhazy (the wife to the Austrian ambassador to Britain); Bourne, Palmerston, p. 191. Almacks, King Street, St. James, was founded in 1765 by a Scotsman named MacCall who scrambled the letters of his name to make Almacks. British aristocratic women continued its exclusivity until about 1835 in $R$. $H$. Mottram, "Town Life of London," in Early Victorian England, 1830-1865, 2 vols., ed. G. M. Young (London: Oxford University Press, 1934 ; reprint ed., London: Oxford University Press, 1951), 2:182.

${ }^{28}$ Ilchester, Chronicles, p. 236. Lady Holland did invite O'Connell to many other social functions though Diane Davids Olien, Morpeth: A Victorian Public Career (Washington, DC: University Press of America, 1983), p. 191, n. 84. The controversial O'Connell also was a problem guest at Radical Party functions. Mrs. Grote controlled access of O'Connell to the leaders of the Radical party. "In a style reminiscent of Lady Holland, Mrs. Grote took great delight at never having had O'Connell to dine. She blamed him for the lack of Radical Unity." Newbould, Whiggery and Reform, p. 191.

p. 431 .

${ }^{29}$ Philip Guedalla, Palmerston (New York: Putnam, 1927),

${ }^{30} \mathrm{John}$ Prest, Lord John Russell (London: Macmillan, 1972), pp. 182-183.

${ }^{31}$ Diary entry 20 June 1805; Charles Abbott, The Diary and Correspondence of Charles Abbott, Lord Colchester, Speaker of the House of commons 1802-1817, ed. Charles Abbott, Lord Colchester, 3 vols. (London: Murray, 1861), 2:11. In 1803, Pitt suddenly became Prime Minister. He offered Lady Hester a home. She was his political hostess until his death in 1806. She "had considerable influence over her uncle and contrived to have a finger in most of the ministerial pies." When some asked Pitt why he let her have so much power he said "I let her do as she pleases, for if she resolved to cheat the devil himself, she would do it." George Paston Symonds, Little Memoirs of the Nineteenth Century (London: Grant Richards, 1902; New York: Dutton, 1902), p. 219. She was "proud of her influence from the first and exercised it on every occasion and upon all who come into her sphere." Joan Haslip, Lady Hester Stanhope: A 
Biography (London: R. Cobden Sanderson, 1934), p. 8. She attended to his correspondence, "arranged governmental hospitality, and dispensed a good deal of patronage." Herwald Ramsbotham, Lord Soulbury, "Women of Influence, 1750-1800," Quarterly Review 297 (1959):401. But of course this author goes on to state, "But there is no reason to think that she had the slightest effect on the Prime Minister's policy." Soulbury, "Women of Influence," p. 401.

${ }^{32}$ Henry Richard Vassall Fox Holland, The Holland House Diaries, 1831-1840, ed. Abraham D. Kriegel (London: Routledge, 1977), p. 231.

${ }^{33}$ Olien, Morpeth, p. 150 .

${ }^{34}$ Lee, Wives, p. 121.

${ }^{35}$ Emily Eden to Mrs. Lister, Theresa Villiers, 28 Oct 1834 in Miss Eden's Ietters, ed. Violet Dickinson (London: Macmillan, 1919), p. 243.

${ }^{36}$ Emily Eden to Theresa Villiers Lister, 23 Nov 1834, in Miss Eden's Letters, p. 248.

${ }^{37}$ Bourne, Palmerston, p. 234.

${ }^{38}$ Lee, Wives, p. 76 .

${ }^{39}$ Lady Shelley, 4 March 1819, diary entry in Diary of Lady Shelley, 2:31.

${ }^{40}$ Airlie, Lady Palmerston, p. xv.

${ }^{41}$ Hawes, Henry Brougham, p. 89.

${ }^{42} 19$ Feb 1830, Harriet Fane Arbuthnot, The Journals of Mrs. Arbuthnot, 1820-1832, eds. Francis Bamford and the Duke of Wellington, 2 vols. (London: Macmillan, 1950), 2:336.

${ }^{43}$ There is considerable debate over whether they were lovers. Certainly they were very close friends. See also Rubeigh James Minney No. 10 Downing street: A House in History (Boston: Little Brown, 1963), p. 198.

44 Hugh Stokes, The Devonshire House Circle (London: H. Jenkins, 1917), p. 19 .

${ }^{45}$ Charles Cavendish Fulke Greville, The Greville Memoirs, 1821-1860, revised ed., ed. by Roger Fulford (New York: Macmillan, 1963), p. 281. 
${ }^{46}$ Ilchester, Chronicles, p. 241. In July 1822 the Tory Lord Chancellor Lord Eldon and Lord Aberdeen dined at Holland House. Lady Holland in 1834 held a "High Tory Dinner to please the little Duchess of Bedford." Other Tory dinners at Holland House included a large party in 1835 that included the Tory Lord Aberdeen (Secretary of War under Peel) as noted in Ilchester, Chronicles, p. 29.

${ }^{47}$ Lee, Wives, p. xvii.

${ }^{48}$ Letter of Mrs. Arbuthnot to Lady Shelley 16 Feb 1828, Shelley, Diary of Iady Shelley, 2:175.

${ }^{49}$ Lee, Wives, p. iii.

${ }^{50}$ Trevelyan, Lord Grey, p. 236.

${ }^{51}$ Symonds, Little Memoirs, p. 219.

${ }^{52}$ Peter Mandler, Aristocratic Government in the Age of Reform Whigs and Iiberals, 1830-1852 (Oxford: Clarendon, 1990), p. 104 .

${ }^{53}$ Mitchell, Holland House, p. 108.

${ }^{54}$ Bourne, palmerston, p. 227.

${ }^{55}$ Newbould, Whiggery and Reform, p. 4.

${ }^{56}$ Mandler, Aristocratic Government, p. 59.

${ }^{57}$ Ibid., p. 45 .

${ }^{58}$ The houses of the Duke of Devonshire, the Duke of Bedford and Lord Holland.

${ }^{59}$ Smith, Lord Grey, p. 20.

${ }^{60}$ Haslip, Lady Hester, p. 15.

${ }^{61}$ Philip Ziegler, Melbourne: A Biography of William Lamb, Second Viscount Melbourne (London: Collins, 1976), p. 59 .

\footnotetext{
${ }^{62}$ Lewis, "Political Behavior", p. 253.

${ }^{63}$ Haslip, Lady Hester, p. 48.

${ }^{64}$ Cecil, Melbourne, p. 56.

${ }^{65}$ Blackburne, Ladies' Chain, p. 75.
} 
${ }^{66}$ While one author believes that "Since Lady Melbourne was never really accepted by the greatest families, and never aimed at giving an exclusively political complex to her house, it hardly included the innermost circle of the Whig political aristocracy." Bertram Newman, Lord Melbourne (London: Macmillan \& Co., 1930), p. 7. How can this be when Fox, Prince of Wales, Windham, Canning, and Sheridan were continually at her political salon?

${ }^{67}$ Strickland, Byron Women, p. 98.

${ }^{68}$ Mabel, Countess of Airlie, In Whig Society, $1775-1818$. Compiled From the Hitherto Unpublished Correspondence of Elizabeth, Viscountess Melbourne and Emily Lamb, Countess Cowper, Afterwards Viscountess Palmerston (London: Hodder and Stroughton, 1921), p. 102 .

${ }^{69}$ D. B. Wyndham Lewis, Four Favourites (New York: Longmans, Green, 1949), p. 59.

${ }^{70}$ Oliver Bernier, The Eighteenth Century woman (New York: Doubleday and the Metropolitan Museum of Art, 1981), p. 106.

${ }^{71}$ Robert Wark, Meet the Ladies:Personalities in Huntington Portraits (San Marino, CA: Huntington Library, 1972), p. 67 .

72 "Her mansion in London long formed the chief resort of the leaders of the Tory Party, as that of the Duchess of Devonshire was that of the Whigs." William Anderson, Scottish Nation, 3 vols. (Edinburgh: A. Fullerton, 1863), 2:319. See also Alexander Fergusson, The Honourable Henry Erskine, Iord Advocate for Scotland with Notices of Certain of His Kinfolk and of His Time (Edinburgh: W. Blackwood, 1882), p. 286 .

${ }^{73}$ Jenifer S. Uglow, ed., The Continuum Dictionary of Women's Biography, new expanded ed. (New York: Continuum, 1989), p. 210. See also Leslie stephen and Sidney Lee, eds., Dictionary of National Biography, 22 vols. (London: Oxford University Press, 1917; reprint ed., London: Oxford University Press, 1949-50).

${ }^{74}$ George Canning, The Letter Journal of George Canning 1793-1795, ed. Peter Jupp, Camden Miscellany 4th Series, vol. 41 (London: Royal Historical Society, 1991).

${ }^{75}$ Soulbury, "Women of Influence," p. 401. 
${ }^{76}$ Mandler, Aristocratic Government, p. 56.

${ }^{77}$ Though the author goes on to say that "the essentially acrid humor of her [Lady Holland] temperament does not contrast favorably with the easy grace and good will of Devonshire House." Stokes, Devonshire House, p. 4.

${ }^{78} 30$ August 1820, Henrietta Elizabeth Leveson Gower Granville, A Second Self: The Letters of Harriet Granville, 1810-1845, ed. Virginia Surtess (Salisbury, wiltshire: Michael Russell, 1990), p. 140.

${ }^{79}$ Lady Holland, Elizabeth Vassal Fox, was married at age 16 to Sir Godfrey Webster. She divorced him in 1797 on grounds of her adultery with Lord Holland, whom she married three days after the divorce was finalized. She was not invited to the court of Queen Victoria, though because of her divorce. Thomas Coke never invited Lady Holland to his estate, Holkham. As a result Lord Holland never went either. She always invited Coke to Holland House though and he sent her turkeys, etc. for her larder. Ilchester, chronicles, pp. 173-174.

${ }^{80}$ Airlie, In whig Society, pp. 25-26.

${ }^{81}$ One author said Lady Holland "revenged herself by drawing away their husbands night after night" because they did not accept her socially. Ziegler, Melbourne, p. 60.

${ }^{82}$ Ilchester, Chronicles, p. 348.

${ }^{83}$ Greville, Greville Memoirs, p. 178.

${ }^{84}$ Fyvie, Notable Dames, p. 177.

${ }^{85}$ Henry Holland, Recollections from a Past Life, 2nd ed., p. 229, quoted in Fyvie, Notable Dames, p. 178.

${ }^{86}$ Diary entry 12 August 1834, Thomas Moore, Tom Moore's Diary, selected ed., edited by J. B. Priestley (Cambridge, England: Cambridge University Press, 1925), p. 180.

${ }^{87}$ Lewis, Four Favourites, p. 75.

${ }^{88}$ Leslie Mitchell, Holland House (London: Gerald Duckworth, 1980), p. 303 .

${ }^{89}$ Prudence Hannay, "The Redoubtable Lady Holland," History Today 23 (1973):98.

${ }^{90}$ Hannay, "Redoubtable," p. 98. 


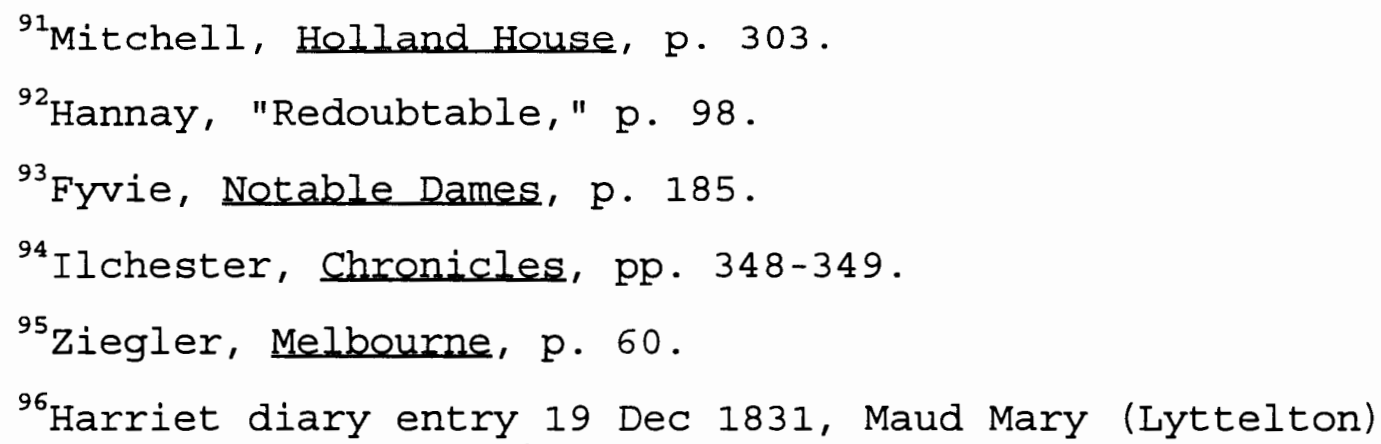
Wyndham, Baroness Leconfield, ed., Three Howard Sisters: Selections From the Writings of Lady Caroline Lascelles, Lady Dover, and the Countess Gower, 1825 to 1833 , revised and completed by John Gore (London: John Murray, 1955), p. 229. Georgiana's daughter Georgiana (Little G) married George Howard. Little $G$ had three daughters, all active politically. These were Lady Caroline Lascelles, Georgiana, Lady Dover, and Harriet, Countess Gower. Maud Leconfield edited the letters of these three sisters. They demonstrate how politically active they were, even during years of childbearing and childrearing. Harriet, Georgiana's other daughter, married Lord Granville, the politician and diplomat. We also have volumes of her letters published (see References under Henrietta Granville), many of which show her keen interest in politics.

${ }^{97}$ Fyvie, Notable Dames, p. 191.

${ }^{98}$ Ilchester, Chronicles, p. 348.

${ }^{99}$ Mitchell, Holland House, p. 307.

${ }^{100}$ Elizabeth Vassall Fox Holland, Elizabeth Lady Holland to Her Son 1821-1845, ed. Earl of Ilchester (London: John Murray, 1946), p. 97.

${ }^{101}$ Hannay, "Redoubtable," p. 102.

${ }^{102}$ Macaulay to Hannah $8 \mathrm{July} 1831$, Thomas B. Pinney, ed., Letters of Thomas Babington Macaulay, vol 2: March 1831 - December 1833 (Cambridge, England: Cambridge University Press, 1974-1981), 2:65.

${ }^{103}$ Airlie, In whig Society, p. 110.
${ }^{104}$ Mandler, Aristocratic Government, p. 60 . His father died in 1831 and he became Lord Mulgrave. In 1838 he was raised in the peerage by the Whigs to the marquisate as Lord Normanby. 
${ }^{105}$ Michael Roberts, The Whig Party 1807-1812 (London: Macmillan, 1939; reprint ed., New York: Barnes \& Noble, 1965), p. 374 .

${ }^{106}$ Bourne, Palmerston, p. 374 .

${ }^{107}$ Ibid., p. 191 .

${ }^{108}$ Ibid., p. 227.

${ }^{109}$ Guedalla, palmerston, p. 233.

${ }^{110}$ Over the importance of the Eastern Question being decided at their dinner table. Lady Cowper to Beauvale, 12 Oct 1840, Donald Southgate, "The Most English Minister..." The Policies of Palmerston (London: Macmillan, 1966), p. 136 .

${ }^{111}$ Southgate, Most English, p. 126.

${ }^{112}$ Lady Cowper and Palmerston had a well accepted affair for many years. She provided informal structure of information and influence but their marriage brought them both great power and influence.

${ }^{113}$ Lord Holland December 1839 quoted in Bourne, Palmerston, p. 583 .

${ }^{114}$ Third Viscount Palmerston, Letters of the Third Viscount palmerston to Laurence and Elizabeth sulivan 1804-1863, ed. Kenneth Bourne, Camden Miscellany 4th Series, vol. 23 (London: Royal Historical Society, 1979), p. 273, note 1 .

${ }^{115}$ Southgate, Most English, p. 126.

${ }^{116}$ Granville, Life of Granville, $2: 127$.

${ }^{117}$ Airlie, Lady Palmerston, $1: 7$.

${ }^{118}$ Emily Eden to Miss Theresa Villiers, sept 1826 , in Miss Eden's Letters, p. 107.

${ }^{119}$ Mandler, Aristocratic Government, p. 106.

${ }^{120}$ Von Den Steinen, "Discovery", p. 233.

${ }^{121}$ IBID. , p. 237.

${ }^{122}$ Georgiana Spencer, Duchess of Devonshire, Georgiana: Extracts From the Correspondence of Georgiana, Duchess of 
Devonshire, ed. Earl of Bessborough (London: John Murray, 1955), p. 10 .

${ }^{123}$ Stokes, Devonshire House, p. 316.

${ }^{124}$ She began to hold small dinner parties three months after Holland's death. Ilchester, Chronicles, p. 285.

${ }^{125}$ Fyvie, Notable Dames, p. 198.

${ }^{126}$ October 1845, quoted in Georgiana Blakiston, Lord William Russell and His Wife 1815-1846 (Wilmington, DE: Scholarly Resources, 1972), p. 513.

${ }^{127}$ Greville, Greville Memoirs, p. 211.

${ }^{128}$ Stokes, Devonshire House, p. 318.

${ }^{129}$ Helen Tierney, Women's Studies Encyclopedia, 3 vols. (New York: Greenwood Press, 1989), 3:400.

130 "In an era in which men wore white or black stockings to formal events, blue stockings signaled informality". Bonnie Anderson, History of Her Own, (New York: Harper \& Row, 1988, 1989), 2:111

${ }^{131}$ Mitchell, Holland House, p. 302 .

${ }^{132}$ Anderson, History of Her Own, 2:113. A saloniere was a woman in French society who "organized and presided over intellectual conversations in her home and thus helped mold elite secular culture." Tierney, women's studies, 3:399. Examples of French salonists were Mme. Geoffrin, Julie de Lespinasse, Suzanne Necker, and Mde. du Deffand.

${ }^{133}$ Anderson, History of Her Own, $2: 106$.

${ }^{134}$ Anderson, History of Her Own, 2:106. The British literary salonists criticized their French counterparts, believing them "frivolous as compared to their own diligence and intensity. They did not consider themselves ladies of leisure, like their French counterparts. They worked, published, travelled, and championed women's education." Tierney, Women's studies, 3:400.

${ }^{135}$ Tierney, Women's studies, 3:400. 
CHAPTER III

\section{PATRONAGE}

Patronage was the process of obtaining government posts for family, friends, constituents, and others. It was the right of control of appointments to offices and other privileges in the public sector. Political patronage was central to the working of the political/social nexus. It "lay at the heart of political life."

Patronage itself was both a political and social relationship. Patronage was a vital part of eighteenth and nineteenth century political process for two reasons. First, national political party organizations did not control patronage. "In the absence of the disciplines of party, patronage was the necessary mortar in the complicated process of political bricklaying." ${ }^{2}$ Second, Members of Parliament were not paid.

In an age when members were paid no salaries, some compensation was expected for the expense of getting oneself elected, maintaining a house in London during the sessions. . . Indeed, a man who was granted no favor was regarded as a fellow of little consequence.

And British aristocratic women who directed the process of patronage were also regarded as people of consequence. British aristocratic women directed political patronage to 
relatives (by blood, marriage, and intimacy), friends, constituents, and party. The most common type of political patronage directed by British aristocratic women were government appointments (clerkships, secretaryships, diplomatic), military appointments, granting of titles, religious appointments, and pensions. Patronage worked both ways for British aristocratic women. Women were the conduit of patronage. People (through family members, friends, or constituents) asked British aristocratic women for patronage in such areas as major and minor government positions, diplomatic and military posts, pardons, pensions, livings, and titles. British aristocratic women in turn asked their family members and friends to help them. People requested patronage of British aristocratic women, both in person and through letters." Patronage involved a whole set of mutual dependencies that bound the fabric of politics and society during this time period. Those who requested patronage developed a dependent relationship on whom they requested the patronage. The patron who granted the patronage had a high level of control over those to whom they granted patronage. This was true for both men and women.

Women exercised great political power through their ability to solicit patronage successfully. The political system depended on the power of British aristocratic women to direct patronage and political patronage gave British 
aristocratic women great power in society. It was a sign of the great political influence of Lady Canning when Peel made an offer to her son of a government post in the Treasury. ${ }^{5}$

Women were accepted as vital participants in the patronage system. Mrs. Arbuthnot described Lady Jersey as the "leader always where balls and patronage are in question," Lady Salisbury was "said to have zealously used her wit, her audacity, and her social talent for the furtherance of her husband's parliamentary influence. "7

Lord John Townshend ended up, as most people do who wrote to Lady Melbourne did, by asking her to compass a favor for men through William Huskisson, the new Surveyor of Woods, who had married Lady Melbourne's niece.

British aristocratic women could be quite vehement in their quest for patronage. "My Lady Carlisle, thro' My Lady Yarmouth, is a warm and angry solicitor for your friend Mr. Dampier." ${ }^{9}$ During Lord North's administration it seemed he had given to somebody in opposition a place which Lady Stafford (then Lady Gower) had solicited for her brother, Keith Stewart. Soon afterwards, Lady North met Lady Gower at the Chapel at St. James on a Sunday. As the two women came down the aisle after communion "Lady Gower whispered to Lady North "Your husband is much more disposed to serve his enemies than his friends. "10

A paradox sums up the entire experience of British aristocratic women and politics during this time period. On 
one hand they could not actually sign the papers or issue the decrees to grant a relative a new position. Yet, on the other hand, contemporaries perceived British aristocratic women as having the power to grant that same patronage. ${ }^{11}$

Contemporaries did not equate patronage with corruption or bribery. Patronage was just how things worked. There were few members of Parliament in the eighteenth or nineteenth century who did not seek, and obtain, some small mark of favor for themselves, their relatives, or their constituents. Not all women thought the patronage system was good; some women saw dangers in the system. Charles James Fox was not strong on patronage. Lady Sarah Napier, a relative of Fox, even though she wanted some position for her two soldier sons, said

I hear that Charles Fox is so thoroughly occupied with the essential business of England viz with Bonaparte, that he lets Lord Grenville take a much larger share of loaves than belongs to him. . . I admire him very much for it.

While not viewed as corrupt, contemporaries did see that patronage did not always result in the appointment of the most competent people. Lord Melbourne commented on Lady Holland's frequent requests for patronage. He said "You seem to have one fixed principle and that is to choose the man with the worst character in the list of candidates."13 Patronage was not considered unnatural, for potential members of the government came from the same class and were friends 
of British aristocratic women. The small size of the ruling political and social class gave women great influence in providing patronage.

For the most part, the political party in power could direct and were expected to direct a much higher degree of patronage than the party out of office. For example, in 1806 when the Whigs came back into power, Whig British aristocratic women had more influence. Lady Holland "never rested" until she induced the Chancellor to give her friend Sydney Smith (a most unreligious man) a living. Before 1806 she had been unable to do so. ${ }^{14}$ In 1781, Lady Pembroke said to her son, Herbert,

I am rather sorry for no more favors asked while we remain in opposition, for I find it is a very general opinion that favors in any position are not to be expected when in red hot opposition to Government.

However, powerful enough British aristocratic women were expected to direct patronage even though they were in opposition. Lady Melbourne "often felt able to ask favors which were not refused," even though her party was in opposition for many years. ${ }^{16}$ Georgiana's requests for patronage were also only rarely refused. British aristocratic women often used other women as intermediaries on both sides of the patronage system. British aristocratic women solicited patronage for members of their families. They obtained high government positions for husbands and 
brothers and sons and nephews with diplomatic or military posts. They were also able to obtain titles and pensions for relatives and themselves.

The patronage activities of British aristocratic women can be divided into three categories based on the type of person they assisted--family, friends, and other. Family was the primary category of people for whom British aristocratic women directed patronage. This included their own birth families and that of their husband's. British aristocratic women fought frequently over high government positions in Ireland. Lady Lyndhurst in 1830, lobbied strongly for her husband to have the post of Chief Baron of Ireland. She was successful though many think she forced her husband into the position.

Others seem to consider Lord Lyndhurst as much falled, and irrecoverably, by his acceptance of the Chief Barony. I feel he is, too, and pity him. His poverty consented [sic] and his wife forced him.

Lavinia Spencer also pushed a little hard to get her husband the position of Lord Lieutenant of Ireland. Ranting against Mr. Pelham, who was also running for the position "Lavinia has taken into her head all manner of doubts of Mr. Pelham; her sister warned her against Pelham saying 'no body of weight would support our administration. " 18

Other government positions in Ireland also were attractive lobbying points for male relatives of British 
aristocratic women. In 1793-94, Katherine, the wife of Sylvester Douglas, Lord Glenbervie, obtained for him the post as Secretary to Ireland. In order to obtain this post she wrote a letter to her father, Lord North. Lord Glenbervie accepted this and valued his wife highly for all the patronage she brought to him. He stated that "I myself conjecture that Lady Katherine's letter [to Lord North] forwarded it [his position] very much." ${ }^{19}$ Lady Wellesley, in 1833, also obtained a post for her husband in Ireland. "Lady Wellesley took credit to herself for Lord W's appointment [to Ireland], by making the King suggest him to Lord Grey." 20 Even while deeply involved in other political matters, British aristocratic women lobbied for positions for family members. In the middle of the Regency Crisis of 1788-89 Georgiana "actively and aggressively promoted" her brother for Lord Lieutenant [of Ireland]. She lobbied the Prince of Wales, the Duke of Portland, and her husband. It was not successful. ${ }^{21}$

Lady Melbourne was a good example of how a British aristocratic women could successfully use patronage to push and forward the interests of her sons and husband. ${ }^{22}$ Lady Melbourne obtained a good post for her son Frederick Lamb with Lord William Bentinck. ${ }^{23}$ In 1803 she solicited the Prince of Wales for a government post for her son William Lamb, later Lord Melbourne the Prime Minister. The Prince 
wrote to Lady Melbourne, saying that in this case he must decline to appoint William Lamb to the Stannaries. However he continued to assure Lady Melbourne that he would continue to support her. "Rest assured of this, that whilst I live I never will neglect an opportunity in which I can be of use to any of yours or in any way I can forward any wish of yours." 24 Later in 1805 the Prince of Wales wrote to Lady Melbourne telling her that he was pushing the career of another one of her sons. He wrote her a long letter discussing the various options for her son, Frederick Lamb. ${ }^{25}$ In 1812 the Prince offered a third son, William Lamb, a place in the treasury in honor of his mother. This Lamb refused, but his letter was "so diplomatic and yet so sincerely worded that it is possible to imagine that his mother might have been at his elbow as he wrote." 26

In addition, other British aristocratic women solicited government posts for family members. In 1834 the Countess of Sandwich asked for a post in government for her nephew. ${ }^{27}$ The Duchess of Gordon frequently asked for positions for relatives. ${ }^{28}$ As the leading Scottish British aristocratic woman, the Duchess must also had been flooded with requests from people from Scotland, both kin and friends. She served as the general dispenser of patronage for Scotland, a productive pipeline of patronage for scots. 
Diplomatic posts, were another popular source of government patronage opportunities for British aristocratic women. Women's Influence "weighed most heavily in the Foreign office." ${ }^{29}$ British aristocratic women actively pursued them for their family members. In 1832 Lady Grey got her husband to force Lord Palmerston to appoint her brother, Lord Ponsonby, to the ambassadorial post in Naples. The Naples post, because of its good climate and less onerous duties than other posts, was highly sought after. ${ }^{30}$ Lady Shelley wrote to the Duke of Wellington in 1819 to obtain a post in Jamaica for her nephew. ${ }^{31}$ Lady Elizabeth Foster got her friend the Duke of Richmond to give her brother an ambassadorship at Florence. ${ }^{32}$ She also got the Prince of Wales to appoint her son Augustus Foster to be the British Minister at Washington. Although she "refused to take credit for the appointment" she revelled in her power. ${ }^{33}$ Augustus would have preferred a seat in Parliament, but Elizabeth forced him to Washington.

Lady Malet was married to Sir Alexander Malet of the Foreign office. She was also the step daughter of Lord Brougham. In 1835, she got Brougham to appoint Malet as a secretary to the legation at the Hague. ${ }^{34}$ In 1841 Lord William Russell described how Lady Burghersh obtained a position for her husband. "Heard from a good source that Lady Burghersh made the Duke of Wellington ask for Berlin for 
Burghersh, he being ruined and in immediate want of money." ${ }^{35}$ In 1823, Lady Granville (Hary-O) obtained a post in Berlin for Lord Clanwilliam. Creevey commented "Mr. Canning's diplomatic dependents are amazed at such a thing having slipped through their fingers." ${ }^{36}$ Lady Anne Barnard was a close friend of Dundas. Through this friendship she was able to make Dundas appoint her husband to the position of secretary to Lord Macartney, the first Governor of the Cape of Good Hope. ${ }^{37}$ In 1830 Lady Cowper pressed Princess Lieven to pressure her lover, Lord Grey, to appoint Palmerston to head the Foreign office. ${ }^{38}$

Lady Holland was famous for working strenuously to obtain governmental positions for her husband. In 1806, when the Whigs returned to power, Charles James Fox asked Lord Holland which position in the Cabinet he wanted. Holland replied that since Lady Holland enjoyed living abroad he would like an ambassadorship. ${ }^{39}$ John Cam Hobhouse, the radical politician and writer, described a dinner at Holland House in 1827. There he said Lady Holland told him "from the first to the last she had wished Lord Holland to take office." 40 Lord Goderich resigned as Prime Minister in January 1828 and the Whigs resumed power. It was assumed by many that Lord Holland would receive the cabinet post of Foreign Minister; he did not. Joseph Jekyll, wit and politician, wrote 
Lady Holland is the only dissatisfied Minister out of office. She counted on sailing down with her long-tailed blacks and ancient crane-necked chariot to sit with Holland at the Secretary's office, to administer the affairs of England and make sydney Smith a bishop. As for him (Lord Holland), he never cared two pence about the whole job.

British aristocratic women also actively pursued military posts for their family members. Mrs. Arbuthnot obtained a majority for her brother, Mildmay Fane and also later got Wellington to transfer him from the West Indies to Wellington's old regiment. ${ }^{42}$ One result of Lady Hester Stanhope's friendship with the Duke of York, was that the Duke became the patron of her brother Charles. Through this connection to the Duke of York, she obtained a commission for her brother. She was also able to acquire good military appointments for all her half brothers. ${ }^{43}$ Lord Granville in 1857 wrote to Lord Canning saying "Lady Lichfield has asked me to suggest to you to make her son an extra aide-de-camp. I believe he acted in that capacity to the poor general." 44

British aristocratic women requested pardons for family members. Lady Cochrane asked the king directly for pardons for her husband with Parliament. ${ }^{45}$ These pardons demonstrated the political power of British aristocratic women. In 1772 the Duchess of Northumberland asked the King to grant a free pardon to a woman named Mary Hall. ${ }^{46}$ 
British aristocratic women pursued titles for family members and for themselves. Lady Melbourne was a good example of a British aristocratic women obtaining a peerage for her husband. The Complete Peerage said the first Lord Melbourne's steps in the peerage "can be safely be attributed to his wife's charm and skill." 47

In 1776, Lady Beaulieu fought to get earldom for her family. ${ }^{48}$ She wrote many letters to the King strongly urging for this peerage. In 1831, while the Whigs were in power, Lord Holland received a letter from Lady Breadalbane "urging a step in the peerage for her husband. "49

In addition many British aristocratic women solicited titles for themselves. Mary Anne, second Duchess of Ancaster in 1780 requested the Barony of Willoughby from the King. ${ }^{50}$ Three years later the King made the dowager Lady Longford a countess. ${ }^{51}$

Positions at court were also highly sought after by British aristocratic women as sources of patronage. Albinia, Lady Cumberland, pushed her son as a page to George III in a letter to the King dated 7 Jan 1804. She was successful. ${ }^{52}$ Of course to obtain these court positions, you needed to be a supporter of the political party in power. A ruler would not appoint a member of a Whig family to be a member at court if there was a Tory government in power. So the Whigs, who were out of power for so many years, were effectively banned from 
court appointments. Very early in her reign, in 1839, Queen Victoria, refused to remove some of her whig women when the Whig government fell, causing a great political crisis, called the Bedchamber Crisis.

British aristocratic women also showed their patronage strength by requesting and obtaining governmental pensions for members of their family and for themselves. Most of the time widowhood was involved. After the death of her husband, Lady Canning became quite active in her pursuit of a pension she thought adequate for the widow of a Prime Minister. She caused a stir. She "has been threatening and doing everything that is blackguard in order to get a pension or a sum of money. She wanted 4,000 a year or 50,000 pounds." 53

British aristocratic women were successful in obtaining government posts for friends. Women through their political influence impacted the appointments to the Cabinet. Lady Glengall in 1830 urged the appointment of one person to the Chancellorship. "Lady Glengall--that intriguess--came to him (Brougham) one evening in great excitement to ask him if Leach would be Chancellor and whether he could do anything to forward it." 54 Lady Cowper attempted to get Lord Palmerston appointed Foreign secretary in 1836. She used her political influence with her brother, Lord Melbourne. However, Palmerston was not popular with party members and disliked by foreign ministers. Melbourne did not like Palmerston as 
foreign minister either. Lady Cowper was not daunted by this aversion to Palmerston. Instead she maneuvered to have her brother (and Melbourne's brother) to come home from abroad to support her fight to get Palmerston appointed. ${ }^{55}$

In 1789 Lady George Spencer (Lavinia) tried to get her husband appointed Lord of the Treasury. She solicited the help of her husband's sister, Georgiana. "Lady George came to me, about an inclination George has to be Lord of the Treasury if it is offered to him. I mentioned it to the Duke." 56 Lady Irwin, in 1782, wanted Lord William Gordon to fill the vacant office of Vice Admiral of Scotland. She wrote a long (and often sarcastic) letter to the Prime Minister, Lord North. In the letter Lady Irwin demanded North appoint Lord William as a "very particular and personal favor upon me." ${ }^{57}$ She wanted to spite the Duke of Gordon who desired his brother, Lord George Gordon, to assume the post.

In addition to obtaining posts for family members, British aristocratic women also solicited patronage for military and minor government posts for friends. In 1759, Lady Mary Wortley Montagu wrote to her daughter Lady Bute to ask her to push for Hugh Graeme with Mr. Pitt. In the next year we also see her promoting other men such as sir James Stewart and "Pool" Mr. Anderson. ${ }^{58}$ Georgiana, Duchess of Devonshire, helped a son of a friend of Edmund Burke to find employment in the civil service. She wrote him a letter of 
introduction and recommendation. ${ }^{59}$ Georgiana also gave Sir John Moore, the important Peninsular War hero, his start in his military career by giving him the money necessary to purchase his majority. ${ }^{60}$ Coutts, the banker, was appointed as banker to the Prince of Wales through Georgian's influence. ${ }^{61}$ In 1840 Henrietta (Harriet) Granville, Duchess of Sutherland and Mistress of the Robes, asked for a clerkship for a 16 year old William white. ${ }^{62}$

Appointments to religious posts were frequently objects of British aristocratic women's patronage because women's roles included the care of the careers of younger sons. The religious life, like the military, contained accepted careers paths for them. In 1777 Mrs. Thrale pushed the king to appoint Mr. Evans for a vacant living at St. Olave in Southwark, her borough. She was successful. ${ }^{63}$ Lady Lyndhurst sent a message by Lady Beauvale to offer a curate position to Harry Sulivan, the nephew of Lord Palmerston. ${ }^{64}$ Perhaps the most famous example quoted in the literature was Lady Holland pushing the promotion of the unreligious sydney Smith.

British aristocratic women also pushed for titles for friends. Jane, the Duchess of Gordon, got Henry Dundas to get an English earldom for her husband. ${ }^{65}$ she also got her husband appointed the Keeper of the Great Seal (Scotland). Lady Sarah Lennox (Bunbury) "began to pull wires" to get Lord 
Carlisle the coveted order of the Thistle. She got it. ${ }^{66}$ Lady Holland asked Melbourne to make Lord Elphinstone an English peer before he left office. ${ }^{67}$ Mrs. Bouverie also pressed Charles James Fox for patronage for family and friends. ${ }^{68}$

Obtaining pensions for friends was a great source of power for British aristocratic women. It allowed them to show both their high level of influence and high level of magnanimity. The Dowager Duchess of Buccleuch got Fanny Burney to ask the Prince of wales to continue the English pension of the Duchess of Fitzjames (for her friend, the widower the Duke of Fitzjames). ${ }^{69}$ Like, Jane Duchess of Gordon, the Dowager Duchess was able to act as a leader in granting patronage to scots. Lady Shelley appealed to her friend, the Duke of Wellington for a government assistance for a widow Mrs. Despard. ${ }^{70}$ Lady Hester Stanhope "using her powerful influence" obtained a pension for a friend of her half brother Charles, William Napier. ${ }^{71}$ This involved crossing party lines as William Napier was the son of a staunch Whig, Sarah Lennox.

\section{CONCLUSION}

Patronage was closely intertwined with the role of political hostess with its controlled introduction of young men, younger sons included, into politics and society. 
Patronage was also related to the role of electoral patron where British aristocratic women actually oversaw the nomination and election of men in parliament.

Compared to other political activities, such as political hostessing, political advising, and electoral activities, women's patronage activities were little discussed in the contemporary literature. It is almost as if patronage was so much a part of their role in society it was just expected of women to arrange or provide patronage. Far fewer examples of patronage activities of British aristocratic women than for other political activities were mentioned in the contemporary material. Yet when mentioned, patronage seemed a natural occupation of British aristocratic women, something taken for granted. 
ENDNOTES FOR CHAPTER III

${ }^{1}$ OED quoted in J. M. Bourne, Patronage and Society in Nineteenth Century England (London: E. Arnold, 1986), p. 3 . Patronage was the "system of personal selection from amongst one's kinsmen and connections" was the instrument by which property influenced recruitment to those positions in society which were not determined by property alone" Harold Perkin, The Origins of Modern English Society 1780-1880 (London: Routledge \& Kegan Paul and University of Toronto Press, 1969), p. 45. Bourne, Patronage, is an excellent source for understanding the role of patronage in the 19th century in Britain. Another author astutely questions whether patronage actually affected or "were substantial to affect political behavior is quite another matter" and out of the scope of this chapter J. B. Owen, "Political Patronage in Eighteenth Century England," in Triumph of Culture: 18th Century Perspectives, eds. Paul Fritz and David Williams (Toronto: Hakkert, 1972), p. 374. In this chapter I will not talk about electoral patronage, the control of nomination of members of parliament, or county or borough governmental positions. That will be in Chapter V.

${ }^{2}$ Bourne, Patronage, p. 17.

3Owen, "Political Patronage," p. 374. See also Jones, "Women and Chartism".

${ }^{4}$ What role the press had in patronage remains to be investigated.

${ }^{5}$ This was in 1834 when Peel was forming the new cabinet. Lady Canning was flattered but the son did not take the position Norman Gash, Sir Robert Peel: The Life of Sir Robert Peel After 1830 (Totowa, NJ: Rowman and Littlefield, 1972), p. 90 . $2: 23$.

${ }^{6} 23$ April 1826, Arbuthnot, Journals of Mrs. Arbuthnot,

${ }^{7}$ Gwendolen Cecil, The Life of Robert, Marquis of Salisbury (London: Hodder and Stroughton, 1921-32), 1:3.

${ }^{8}$ Airlie, In whig Society, p. 88.

${ }^{9}$ Duke of Newcastle to Lord Halifax 1754 Newcastle House ADD MSS. $32736 \pm 182$ quoted in E. Neville Williams, The 
Eighteenth Century Constitution, 1688-1815 (Cambridge, England: Cambridge University Press, 1965), p. 432.

${ }^{10}$ Sylvester Douglas Glenbervie, The Diaries of Sylvester Douglas, Lord Glenbervie, ed. Francis Beckley (London: Constable, 1928), p. 18. See also Soulbury, "Women of Influence," p. 402 .

${ }^{11}$ Many non-contemporary writers do not understand the role of patronage during this time and the importance of women to the entire patronage system. To some writers, only women "pestered" for patronage favors. "The Duchess of Devonshire admitted that she, amongst others, pestered Fox with requests for jobs for her friends" Soulbury, "Women of Influence," p. 402. The author goes on to use this "pestering" as an example of how women have no principles.

Men did not pester; they had principles. The writer ignores the fact that men as well as women were part of the same patronage system. We can be sure that Georgiana herself was in turn pestered by her friends asking for jobs.

${ }^{12}$ Napier was a relative of Charles James Fox. E. Lascelles, The Life of Charles James Fox (London: Oxford University Press, 1936; reprint ed., New York: Octagon Books, 1970), p. 322 .

${ }^{13}$ Cecil, Melbourne, p. 280.

${ }^{14}$ Fyvie, Notable Dames, p. 186.

${ }^{15}$ Lady Pembroke to son Herbert 10 Oct 1781, Henry Herbert Pembroke, Pembroke Papers 1780-1794: Letters and Diaries of Henry, 10th Earl of Pembroke and His Circle, ed. Lord Herbert (London: Cape, 1950), p. 161.

${ }^{16}$ Airlie, In Whig Society, p. 74.

${ }^{17}$ Lord Ellenborough's Diary, 11 Dec 1830, Arthur Aspinall, ed., Three Early Nineteenth Century Diaries (London: Williams \& Norgate, 1952), p. 33.

${ }^{18}$ Georgiana Diary, 13 January 1789, Walter Sydney Sichel, Sheridan. From New and Original Material. Including a Manuscript Diary by Georgiana, Duchess of Devonshire, 2 vols. (London: Constable, 1909), 1:425.

${ }^{19}$ Diary, 27 Dec 1793, Glenbervie, Diaries of Sylvester Douglas, p. 30 . 
${ }^{20} \mathrm{E}$. J. Littleton's Diary, 28 August 1833, in Aspinall, Three Early, p. 359 .

${ }^{21}$ Georgiana Diary, 10-12 Jan 1789, Sichel, Sheridan, $1: 424-425$.

${ }^{22}$ Strickland, Byron Women, p. 101.

${ }^{23}$ Airlie, In Whig Society, p. 102.

${ }^{24}$ The position was in the stannaries, the tin-mines an smelting works of Cornwall and Devon, formerly under the jurisdiction of the stannary courts. Airlie, In Whig Society, p. 74 .

${ }^{25}$ Who was also supposed to be his son via an affair with Lady Melbourne.

${ }^{26}$ Airlie, In whig Society, p. 105. p. 89 .

${ }^{27}$ The nephew was H. Corry Gash. Gash, Sir Robert Peel,

${ }^{28} \mathrm{Gash}$, Sir Robert Peel, p. 89.

${ }^{29}$ Lewis, "Political Behavior," p. 255.

${ }^{30}$ Due to her brother's poor reputation for having too many affairs and laziness, Lady Grey really had to push for her brother. She was successful and he performed well, Bourne, Palmerston, p. 463.

${ }^{31}$ Wellington to Lady Shelley 3 Dec 1819, Shelley, Diary of Lady Shelley, $2: 90$.

${ }^{32}$ Arthur Calder-Marshal1, The Two Duchesses, 1st U.S. ed. (New York: Harper \& Row, 1978), p. 86.

${ }^{33}$ Stokes, Devonshire House, p. 315. She wanted to have firsthand information from America.

${ }^{34}$ Bourne, Palmerston, p. 459.

${ }^{35}$ Diary entry of Lord William Russell 19 Dec 1841 Blakiston, Lord William Russel1, p. 454 .

${ }^{36}$ Quoted in Lewis, "Political Behavior", p. 255.

${ }^{37}$ Canning, Letter Journal, p. 188. 
${ }^{38}$ Bourne, palmerston, p. 330 .

${ }^{39}$ Henry Richard Vassall Fox Holland, Further Memoirs of the Whig Party During My Time 1807-1821 with Some Miscellaneous Reminisces, ed. Lord Stavordale (New York: E. P. Dutton, 1905), 1:78.

${ }^{40}$ Recollections of a Iiving, quoted in Ilchester, Chronicles, p. 81 .

${ }^{41}$ Joseph Jekyll, Correspondence, ed. Algernon Bourke (London: J. Murray, 1894), p. 176.

${ }^{42}$ Arbuthnot, Journals of Mrs. Arbuthnet, $1: 7$ and $1: 68$.

${ }^{43}$ Haslip, Lady Hester, p. 71.

${ }^{44}$ Lord Granville to Canning, 25 July 1857, Granville, Iife of Granville, 1:254.

${ }^{45}$ Holland, Holland House Diaries, p. 133.

${ }^{46}$ Elizabeth Seymour Percy, Duchess of Northumberland, Diaries of a Duchess, 1752-1774, ed. James Greig (New York: Doran, 1927), p. 194.

${ }^{47}$ Quoted in Strickland, Byron women, p. 100. He became an English peer in 1815. One author though said it was Lord North who pushed Peniston to peerage with the King but "later honors he received were chiefly owing to the careful diplomacy of his beautiful wife." Airlie, In Whig society, p. 4 .

${ }^{48} \mathrm{King}$ of Great Britain, George III, The Correspondence of King George the Third From 1760 to December 1783 , ed. Sir John Fortescue, 6 vols. (London: Cass, 1967), 3:261.

${ }^{49}$ Lord Holland diary entry, 16 July 1831, Holland House Diaries, p. 5. The Breadalbanes visited the Hollands where they gave "Somewhat disproportionate expressions of gratitude for their marquisate" (17 September 1831 diary entry), Holland House Diaries, p. 5.

${ }^{50} \mathrm{King}$ to Lord North, 6 Jan 1780, George III, Correspondence of King George, 3:5-6.

${ }^{51} 4$ March 1783, George III, Correspondence of King George, $6: 261-162$. 
${ }^{52}$ King of Great Britain, George III, Iater Correspondence of George III, ed. Arthur Aspinall, 5 vols. (Cambridge, England: Cambridge University Press, 1966-1970), $4: 149$. $2: 185$.

${ }^{53} 2$ May 1828, Arbuthnot, Journals of Mrs. Arbuthnot,

${ }^{54}$ Le Marchant Diary, 15 Nov 1830, in Aspinall, Three Early, p. 5 .

${ }^{55}$ Ziegler, Melbourne, p. 200.

${ }^{56}$ Georgiana Duchess of Devonshire's diary, 13 Jan 1789, in Sichel, Sheridan, 1:245.

${ }^{57}$ Letter, 6 Feb 1782, George III, Correspondence of King George, 5:363. She wrote a sarcastic letter to Lord North, who gave a copy to the King. "My Lord, as Lord William tells me. I did not express my meaning properly. I beg leave to assure you that the very meaning and drift and intention of my letter was that Lord William should be appointed himself to the Place of vice-admiral, and $I$ wish this to be fully explained to His Majesty. I hope your lordship will express to His majesty that by doing so he will confer a very particular and personal favor upon me." The King was not impressed by her demands.

${ }^{58}$ Mary Wortley Montagu, The complete Letters of Lady Mary Wortley Montagu, ed. Peter Halsband, 3 vols. (Oxford: Clarendon, 1967), 3:222.

${ }^{59} \mathrm{His}$ name was Parisot de St. Marie. Edmund Burke, Correspondence of Edmund Burke, 10 vol. (Cambridge, England: Cambridge University Press, 1978; Chicago: University of Chicago Press, 1978), 5:104.

${ }^{60}$ Calder-Marshall, Two Duchesses, p. 33 .

${ }^{61}$ Lewis, "Political Behavior", p. 257.

${ }^{62}$ Palmerston did not grant it as william white was not socially acceptable enough. Bourne, Palmerston, p. 448.

${ }^{63}$ George III, Correspondence of King George, $3: 435$.

${ }^{64}$ Henry William Sulivan (1815-1880) was the son of Palmerston's sister Elizabeth and her husband Laurence Sulivan. Palmerston, Third Viscount Palmerston, p. 296. 
${ }^{65}$ George III, Later Correspondence, 1:454. In July 1784 her husband, Alexander Gordon, was created an English Earl of Norwich. He was also appointed as the Keeper of the Great Seal of Scotland (1794-1806 and 1807-1827). The possibility of this latter appointment upset the Earl of Galloway who wrote to the King in 1789. He was upset because Pitt had told him earlier that there would be no English titles granted. Furthermore, Galloway wanted the office of the Privy seal with its 3,000 pounds per annum for life. He wrote to the King in 1789 alarmed that Jane, Duchess of Gordon, was soliciting the office for her husband. Iord Galloway wrote "But I am now surprised and alarmed to hear that the Duchess of Gordon and Mr. Dundas are soliciting the same for the Duke of Gordon." He feared her power. George III, Later Correspondence, 1:454.

${ }^{66}$ They were flirts. Edith Roehker Curtis, Lady Sarah Lennox: An Irrepressible stuart 1745-1826 (New York: G. P. Putnam's Sons, 1946), p. 203.

${ }^{67}$ Ziegler, Melbourne, p. 293.

${ }^{68}$ Lascelles, Life of Charles James Fox, p. 322.

${ }^{69}$ Francis Burney D'Arblay, Diary and Letters of Madame d'Arblay $(1778-1840)$, ed. Charlotte Barrett, preface by Austin Dobson, 6 vols. (London: Macmillan, 1904-05), 6:209.

${ }^{70}$ She was the widow of General John Despard who fought in the American Revolution, 22 Feb 1830, Shelley, Diary of Lady Shelley, 2:198-199.

${ }^{71}$ Haslip, Lady Hester, p. 71. 
CHAPTER IV

POLITICAL ADVISING

INTRODUCTION

British aristocratic women acted as political advisors throughout the mid-eighteenth to mid-nineteenth century. Political advising encompassed advice on specific topics, such as the Reform Bill of 1832 or how to run the election in Westminster in 1784 and advice on governmental policies, both foreign and domestic. While this role of political advisor was an important role in society and politics, it was also part of their accepted and required societal responsibilities.

The four major functions of the political advisor were to serve as intermediary, political whip, issue and policy advisor, and political appointment advisor. British aristocratic women functioned as intermediaries between individual politicians, political factions, and political parties. They very effectively settled disputes and quarrels, communicated political information between politicians, advised on issues and policies, and were responsible for bringing individual politicians in and out of office. This was an accepted function for women and one 
function upon which the highly personalized political world of the times heavily depended. As political whips, British aristocratic women were responsible for bringing in men to see their point of view on general issues, such as the war with the American colonies, and to vote on specific bills such as the 1832 Reform Bill. British aristocratic women gave specific advice on issues dealing with foreign and domestic issues and policies. British aristocratic women were also responsible for advising on whom to push into and out of political office.

The diaries, journals, and letters of this time period provide abundant evidence of British aristocratic women's role of political advisor. These materials have been used by historians throughout the years to provide evidence for their various historical theories. Georgiana's diary of the 1788/89 Regency Crisis has been used by many historians of the late eighteenth century. ' she was the only reliable primary source available to historians. Mrs. Arbuthnot's journal has been heavily used in most studies of Wellington, Peel, the Reform Bill, and Catholic Emancipation. ${ }^{2}$ Other historians heavily relied upon the journals and letters of British aristocratic women. ${ }^{3}$ Lady Bessborough wrote almost daily to her friend and lover, Lord Granville Leveson Gower. We have volumes of their correspondence published, but much of it was severely edited. In these letters she revealed her 
competent grasp of political affairs of the time and also how much Granville relied upon her knowledge. For example she described what Lord Hawkesbury and the King said to each other concerning Louis XVIII of France's intrigues; it was she who possessed the information. ${ }^{4}$

Aspinall also used the correspondence between Harriet, Lady Leveson Gower (Georgiana's daughter) and Charles Arbuthnot in 1827 to demonstrate how support or lack of support developed for the formation of Canning's ministry. From this correspondence we can see how important women were in the information flow, how obtaining and dispensing political information was important for some British aristocratic women, and how some women supported a political view opposite to that of their husband. In both letters Harriet begged Arbuthnot to send her data and ammunition against Canning. On the 17th of April she wrote, "I can't say how much obliged to you I should be to put in possession of the case for the anti-Canning side. I am so well disposed for your side." ${ }^{5}$

However, only rarely have historians, who have used the letters from women to prove their theses, acknowledged the underlaying significance of these materials. 6 The Ietters and diaries that historians used to prove their theories about male politicians also reflected British aristocratic women's political mastery. Most historians quoted from the 
material but never acknowledged that political advising was an acceptable and valued role for women during this time period.

This chapter will discuss the four functions of the role of political advisor--intermediary, political whip, issue/policy advisor, and political office advisor. These functions enabled the political advisor to control the flow of political information during this time period. This chapter will also highlight the political advising role of the five major British aristocratic women political advisors -Georgiana, Lady Melbourne, Lady Cowper, Princess Iieven, and Mrs. Arbuthnot - and explore how they functioned as intermediaries, political whips, issue/policy advisors, and political office advisors.

\section{INTERMEDIARY}

As political intermediaries, British aristocratic women were both responsible for, and relied upon, to settle political disputes between individual politicians, political factions, and political parties. British aristocratic women were extremely effective political intermediaries for three reasons. First, society, both political and social, was very small. Women knew (and were often related to) every male politician. Second, women were knowledgeable about politics through their control of the political information flow. 
They knew who was thinking what on issues. Third, British aristocratic women could mediate because they were out of the "official" governmental structure. Women could approach two faction leaders and propose a settlement between them without fearing official reprisals. British aristocratic women were often spokespersons for their family, faction, and political party for the same reason. Often it was politically more expedient if women, not men spoke. At times women could get away with talking about an issue (and talking more violently about it). Lord Holland commented on how Lady Lyndhurst spoke for her husband about his future actions concerning the Reform Bill. "Lady Lyndhurst's conversation would lead one to hope he will not vote against the second reading of the bill, and it betrays much estrangement from the party in opposition." Charles Greville perceived Lady Cowper to be the spokesperson in the Palmerston family. In 1842,

She talks a great deal more than he does, and it is easy to see, through her graceful, easy manner and habitual urbanity how impatient they are of exclusion from office, and how intolerant of any dissent from or opposition to his polity or opinions. ${ }^{8}$

Political factions were rampant and frequently changing during this time period. This political structure demanded the intermediary role of British aristocratic women. It especially taxed their skills at gathering and disseminating political information. British aristocratic women functioned 
most valuably as intermediaries in situations where direct confrontation between two factions would explode the situation or where it would make it flow smoother. In the following letter we can see how valuable Lady carlisle (Georgiana Cavendish Howard) was in the political solution.

I think it most desirable that Lady Carlisle should be the medium of communication. The advantages of that are that it conveys the fact most promptly to Canning and it makes it easy for the Duke to say that he has not communicated with Canning, which as things stand seems desirable.

It would be well therefore if Lady Carlisle can ascertain without delay from the Duke what she says.

The Wellingtonians could not directly talk to the Canningites. So it was Lady Carlisle who spoke to Wellington, to ascertain his opinions on the issue of whether he would assume command of the armed forces under Canning.

Lady Stanley mediated between her husband (the leader of the stanleyites) and the peelites. The stanleyite faction refused to join the government in December 1834. Lady Stanley was often the spokesperson for this faction. After Peel gave his opening session speech, Lord stanley replied in an unfavorable way. Lady Stanley

wrote apologetically to her uncle [and thus on to peel] to explain that the speech had been more anti-ministerial than her husband had wished, but he was obliged to take the line he did it had.

This was an age when politics, for the most part centered around the individual politician, rather than political party. Most political factions revolved around one 
man. British aristocratic women frequently mediated between individual politicians. In 1803 George Canning attempted to get Fox and Pitt united in opposition. He made an approach to Fox through Lady Bessborough and Lord Granville Leveson Gower. "But it was difficult even for Lady Bessborough to extract anything from Fox."11 It was Lady Chatham who patched up a quarrel among Pitt, George Grenville, and Lord Temple. ${ }^{12}$ Lady Jersey mediated between Grey and Wellington. The King told Mrs. Arbuthnot "The Duke of Wellington is entirely in Lord Grey's hands. Lord Grey lets Lady Jersey what he wants to have done and she names it to the Duke and it is done." 13 In 1812, after the assassination of Perceval in May, the Prince wanted Canning to join Liverpool's government. Canning balked at serving in the same cabinet as Castlereagh, with whom he dueled in 1809. The Prince turned to Lady Bessborough to mediate between himself and Canning.

She refused. The Prince accused her of "warping" Canning against Liverpool, and he was correct. She did not want Canning to join that government. ${ }^{14}$

However, it is a fallacy to assume that the motive for mediating between political factions was always to soothe the groups and to calm the waters. At times, women stirred things up between factions in order to meet the needs of their political beliefs. Lady Holland and Lady Hester Stanhope excelled at these calculated, disruptive mediations. 
Lady Holland's calculated disruptive influence stood as a contrast to Georgiana's soothing mediating and Lady Holland rarely did anything without calculating the effects carefully. In 1801, Lady Holland involved herself in the dispute between the various Whig factions. Henry Addington tried to get Grey and the Duke of Bedford, to take office with him without Fox. Lady Holland told everyone that Grey was going to accept Addington's offer. Fox believed Lady Holland's statement. This resulted in an important fracture of the alliance of Fox and Sheridan, who had aligned himself with Addington. ${ }^{15}$ Many politicians confided in Lady Hester Stanhope, despite her abrasive personality. Lady Hester Stanhope disrupted the relationship between Canning and her uncle, Pitt. She thought canning was too close to the Devonshire House Whigs and also to the Grenvillites. ${ }^{26}$

Another unique aspect of British aristocratic women's intermediary function was their ability to obtain political information that was unavailable to most people, the information that had not yet been released to the public or never would be released. During a political crisis in 1811, Sydney Smith described how Lady Holland was at the thick of things.

Never was such a ferment as Pall Mall and Holland House is in!... Lord Lauderdale sleeps with his clothes on, and a pan of ink close to his bedside, with a string tied to the wrist of his secretary in the next room. Expresses arriving every ten 
minutes from the House of Commons and the Whig nobility and commonality dropping in at all hours to dinner and supper

British aristocratic women obtained political information from their role as unpaid ananuesis of male politicians. Women copied letters and other material for relatives and friends, at times advising their writers as they copied. Lady Cowper copied many letters for Palmerston during his illness immediately before his death. She "knew all the state secrets and often acted as her husband's private secretary, copying the private letters with her own hand."18 Mrs. Arbuthnot copied many documents for the Duke of Wellington. On two occasions in 1828 she copied his Catholic Papers. ${ }^{19}$ Betsy Sheridan wrote in her Journal that her sister-in-law, Mrs. Richard Brinsley Sheridan, was busy one night writing out a copy of the Prince of Wales's answer to the restrictions on the Regency which was to go to the Council that very night. "Nothing could be better than it was; for we made her read it to us." 20

However many times women wrote the material themselves and sent it out under the name of their male relative. Lady Cowper actually wrote many of the letters she copied, under the name of her husband. ${ }^{21}$ At times they copied material so well others received the credit for its authorship. Elizabeth Grenville "took such a keen interest in her 
husband's career that she kept a political diary long attributed to him." 22

At times, British aristocratic women got into trouble by writing too much themselves, or interfering too much in the letter's delivery, such as when Lady John Russell edited and mailed the Edinburgh Letter of her husband, that strongly stated his views on the Corn Laws or when Lady Shelley disclosed an indiscreet letter of Wellington's. ${ }^{23}$

In another aspect of correspondence, British aristocratic women obtained political information by viewing original information first hand. They saw political dispatches and documents written and received by male relatives and friends. Throughout the letters and diaries of Mrs. Arbuthnot, we see her examining and commenting on official government documents. He wanted her comments on them. She read the dispatches wellington received from Russia. The "Duke showed me several boxes of papers from the Foreign Office, principally on the subject of the war that has broken out between Russia and Persia." ${ }^{24}$ Lady Holland received documents from the Foreign Office as a matter of course. She was upset when in 1839, Lord Palmerston cut down on free distributions of Foreign office publications to private individuals, including Lady Holland. ${ }^{25}$ Writing to Granville, Lady Bessborough discussed Lady Holland's obtaining official dispatches. "Two such large packets 
arrived to both of them, that it only wanted a red box to make me think out old Administration again." 26 Yet despite Lady Bessborough's belittlement, "undoubtedly Lady Holland knew a great deal as daily from the House of Lords, Lord Holland sent her little notes giving her blow-by-blow accounts of Cabinet affairs." 27 In fact the flow of information was a two way affair at Holland House. Talleyrand dined there two to three times a week, and was given up-to-date accounts of Cabinet decisions. In return, the ambassador allowed the Hollands to see his correspondence with Louis Phillipe. ${ }^{28}$

In addition to talk and correspondence, one important way British aristocratic women obtained political information was by attending debates and other meetings in both Houses of Parliament. British aristocratic women had many reasons for attending Parliament. They dutifully went to hear a family or party member speak. It was also enjoyable and exciting. At times, they attended Parliament because it was the fashion of the day. To many women, attending debates became a female rite-of-passage, with younger women guided by older sisters, mothers, or friends. After reading the diaries and letters of the British aristocratic women, one realizes that attending Parliament was vital to these British aristocratic women, an important information link in their political and social lives. This was one of their primary methods for 
receiving political information, which they in turn dispensed to others.

\section{PARTY WHIP}

One function of the role of political advisor that British aristocratic women performed well was that of whipping in votes. On certain issues they were very successful in bringing in men to vote for their point of view. Through a study of this function, we can see how valuable British aristocratic women were in uniting a group of people behind a specific issue and how male political leaders relied upon them to do so. Charles James Fox relied on Georgiana to bring in the votes for his position on the slave trade. He wrote to her "Pray speak to everybody you can to come down or we shall be lost on the Slave Trade. Morpeth, Ossulston, Lord A.H., Lord H. Petty all away. Pray, Pray send anybody you see." ${ }^{29}$ Horace Walpole wrote to Lady Ossory in 1787, urging her to use her ability to influence Sheridan. "If you could bring over Mr. Sheridan, you would do something. ${ }^{30}$

The Duke of Wellington asked Lady Shelley to whip in some votes in the Lords to vote against the Reform Bill. What do you say to Lord Gage? Could you insinuate to him to come up and vote against the Bill or to give his proxy against it? I know you are a sensible woman, and will manage this affair with discretion. ${ }^{31}$ 
She travelled to the home of Lord Gage to obtain his vote. It was Mrs. Arbuthnot who convinced the Duke of Rutland to support the Catholic Emancipation Bill. ${ }^{32}$ In 1780, Georgiana and her Whig friends canvassed enthusiastically for a bill to rescind the old Penal Laws against Roman Catholics. ${ }^{33}$ Jane, Duchess of Gordon, whipped in votes for the Tories during the Regency Crisis of $1788 / 9$. She

constituted herself as Mr. Pitt's recruiting officer. She would summon undecided or wavering members of Parliament and cajole them into strict adherence to the Tory line. She would invite the party backsliders to her assemblies and convince them of the necessity for their attendance and support.

In 1829 The Duchess of Northumberland whipped up votes for the Catholic Emancipation Bill. ${ }^{35}$

In June of 1827, Mrs. Arbuthnot tallied the vote on a portion of the Corn Law Bill.

We hear they are using every effort to beat us when the clause will be discussed again on Friday, but I have great hopes. I made out last night a list of 120 Peers who I thought would be with us, and many more $I$ thought might be added.

Women were also lobbyists for private legislation, as early as $1698 .^{37}$

\section{ISSUES/POLICY ADVISING}

In addition to the functions of intermediary and political whip, British aristocratic women also advised male politicians on specific issues and policies both in foreign 
affairs, such as the war involving spain and Portugal, and domestic affairs, such as the Reform Bill of 1832. British aristocratic women issued political advise to both men and other women. They were political advisors to male relatives and friends--husbands, lovers, brothers, friends, party, and sovereign. Women also gave political advice to other women, including both friends and family members. ${ }^{38}$

British aristocratic women often advised politicians concerning foreign policy matters. Foreign affairs were not an exclusively male realm. In 1832, Lady William Russell advised the government to support the followers of Dom Miguel against those of Dom Pedro in Portugal. ${ }^{39}$ Lady Holland was internationally known for her advise on relations of England with Spain and Portugal, and with Napoleon. Lady Holland, supporting the Prince of Wales over the war with spain, "constantly urged her husband to accept their policy."40 Indeed, Lady Holland often preferred foreign affairs to domestic policy. Lady Lyndhurst was a frequent visitor to the Foreign Office, giving advice on a variety of foreign policy issues. ${ }^{41}$

Another aspect of British aristocratic women advising on foreign policy affairs that also was a part of their control of the political information flow was their activities as informal communicators or spies. Palmerston used the foreign policy information obtained by British 
aristocratic women in 1829. When Harriet, Lady Granville, returned from Paris in July 1828, Palmerston consulted with her as soon as she arrived home. ${ }^{42}$ Lady Malet obtained political information at The Hague for Brougham in such a very effective manner, that in the Foreign Office, she was called "Brougham's Petticoat." 43 In or out of government, Lady Holland often used her guests as couriers, agents, and as sources of information. ${ }^{44}$

British aristocratic women advised politicians on domestic issues and policies. It was Lady Grey who advised the creation of new peers in order to get the Reform Bill of 1832 passed, and not to rely on the existing peers to change their points of view. In a diary entry of December 1831, Lord Holland stated that

Lady Grey, who in a quiet way has great influence with her husband, is manifestly for vigorous measures and a large increase of the peerage, rather than risk a second defeat in the Lords.

In 1800, Lady Holland advised the Foxite Whigs on the bill against public debtors," or the Abbot bill. She wanted to ameliorate the penalties but felt the wording of this bill was too harsh. She, Tierney, and Sheridan all supported a milder version of the bill. She did not trust Tierney to follow through with his support and she was correct. In a letter to her son she wrote 
When the day came I grew afraid of Tierney's candor, and thought he might yield to Abbot's assurance of the harmlessness of the words. For Tierney would sacrifice the interests of anybody to obtain the occasional popularity of conciliating an opponent. I therefore enjoined Mr. Moore to rely solely upon sheridan. I was right. I provoked Tierney by telling him before Whitbread, that my instructions to Moore were to shun [Tierney].

In addition to advice on specific domestic Bills, British aristocratic women advised politicians on the proper political procedures, what actions they should take when certain political events occurred. They were arbitrators of the politically correct way to behave. In 1784, the Great Seal was stolen from the home of the Lord Chancellor, Lord Thurlow. Georgiana described the theft and the resulting turmoil in a letter to her mother. In the letter she said she was dressing in her room while the Duke of Portland and Fox were writing their response, with Georgiana's input. ${ }^{47}$

In 1791, Fox was attempting to become the leader of the centrist Whig faction between Burke and Paine. Fox debated whether to attend the 14 July 1791 Revolution Dinner. Mrs. Crewe advised that he not go. She advised the same for Sheridan. She wrote in a letter to the Duchess of Portland that Sheridan "was in a great fidget about the meeting which at last he determined on not going to. But I could not help telling him my little opinion [that they not go] when Charles Fox called that Evening. " ${ }^{48}$ 


\section{POLITICAL APPOINTMENTS ADVISOR}

British aristocratic women acted as intermediaries in getting men in and out of political office. Women were especially adept at mediating men in and out of cabinet level positions.

Women frequently mediated to push men into political office. In 1836, Lady Cowper got her friend, Princess Lieven, to recommend Palmerston to Lord Grey, as Palmerston was "presentable and well-mannered." 49

Mrs. Arbuthnot believed it was Lady Tankerville, who was the intermediary between Grey and Wellington, and was responsible for negotiating Lord Grey into office with Wellington. She was a "great confident and friend of Lord Grey's." ${ }^{50}$ The Duke of Rutland solicited Mrs. Arbuthnot for her to get wellington back at the head of the party. He wrote to her "I know how much he [Wellington] attends to your advice and judgment. Cannot you put it into his head to become the head and champion of the party?"1 ${ }^{51}$

In 1830, Lady Burghersh, Wellington's niece, negotiated with various politicians to see if they would join Wellington's cabinet. She first met with her friend, Frederick Lamb, to see if he knew if Melbourne would join the cabinet of Wellington. Later a message from Melbourne to Wellington passed through the "discreet if unconventional 
channel of Lady Burghersh." She was also involved in negotiations with Huskisson and Palmerston. ${ }^{52}$

Katherine, Lady Glenbervie, frequently negotiated with politicians to get her husband into office. Lord Glenbervie wrote,

Lady Liverpool has called repeatedly on Lady Katherine [his wife]. She sent to desire her to come to her this evening. I think Lord Liverpool wishes to sound me about the depending arrangement, or that he wishes to open some sort of negotiation.

It was Mrs. Canning who negotiated with the Duke of Portland to come into the Cabinet of her husband in 1827 . She urged her brother-in-law (the 4 th Duke and son of the Prime Minister) to take office to give much needed support to her husband's government. She wrote to the duke,

Pray do not be startled at the proposition I am about to make to you, and do not say no to it upon the first impulse. Will you consent to come into the Cabinet and lend your name as a sleeping partner to the firm? I ask it of you as a personal ${ }_{54}$ kindness to me not to refuse this proposal. ${ }^{54}$

In fact, Aspinall used the letters to and from many women to illustrate how Canning's ministry was formed. These women include Mrs. Canning, Mrs. Arbuthnot (numerous letters), Lady Liverpool, Lady Harriet Leveson-Gower, Lady Londonderry, Lady Bathhurst, Lady Cowper, Lady Conyngham, Viscountess Sandon, and the Marchioness of Bute. They show how small society was and the close interconnection of politics and society and thus the importance of women in it. 
This letter was also included in E. Anthony Smith's English Historical Documents, 1783-1832. This collection also contained more than ten letters of Canning to his wife, explaining the formation of his government. Smith's emphasis on this letter shows the power of family ties in the period and how the political structure depended upon the political abilities of women. ${ }^{55}$

Women also mediated to push men out of political office. Lady Normanby was responsible for the firing of Palmerston as Foreign Secretary in 1851. When in 1851, Lord Normanby began his dispute with Palmerston over the coup $d$ ' etat of Napoleon, Lady Normanby took their case directly to the Queen. Napoleon's coup was on 2 December 1851. The next day Palmerston met with the French ambassador and told him he, Palmerston, agreed with the coup. On 4 December the Cabinet met to instruct Normanby to be neutral. Palmerston did not tell the cabinet of his earlier talk with the French ambassador. Palmerston passed on the neutrality request to Normanby. But after Normanby found out that Palmerston has already expressed his support for the coup. He began to fight with Palmerston. Lady Normanby took the dispute to the Queen, who then asked Lord John to explain. On 17 December, Lord John fired Palmerston from the Foreign Office, but immediately offered him Ireland. Lady Cowper spoke, of - treachery and stopped inviting Lord and Lady John to her 
Saturday evening receptions. But Lady John was "-All for a good fight and a good fall. " 56

Lady Cowper also mediated to get politicians out of office.

Lady Cowper is the bitterest of all our enemies and I hear she is trying to get Lord Ashley, who is in love with her daughter, out of office and into the ranks of the opposition. I daresay she will succeed. However, he will be no loss for, in talent and sense, he had disappointed us grievously.

One author believed it was Georgiana, along with Lady Melbourne, Sheridan, and the Prince of Wales, who were most "insistent" that Fox resign from the Rockingham administration in $1782 .^{58}$

British aristocratic women advised other politicians about filling cabinet positions in various ministries. In 1806, when the Ministry of All Talents was formed, Charles James Fox consulted with Georgiana over whom to appoint for cabinet positions. ${ }^{59}$ In 1788 , Betsy sheridan wrote a letter to her elder sister discussing cabinet posts, those they could recommend to their brother Richard Brinsley Sheridan. "I am perfectly of your mind about recommendations and told Dick so the first opportunity. He seemed to mind me, but your letters will best enforce the argument."60 Before Palmerston left for vacation in France there was a great gathering of Lambs and Cowpers at Windsor. They discussed future cabinet positions. ${ }^{61}$ 
Brougham was inclined to think that Lady Holland's influence was partly to account for his exclusion in 1812 from the cabinet. ${ }^{62}$ In 1835 Brougham was denied office in the Melbourne government. Brougham railed against Lady Cowper this time. He wrote,

How Melbourne plans to do I cannot tell. His real friends will do well to warn him against trusting to Fred [Lamb] or Lady Cowper, who, of course, will bill for Conservative declarations. This is a view to coalitions. ${ }^{63}$

In December 1816 and January 1817, most of the politicians who frequented Holland House were eagerly anticipating a change. "Lady Holland herself told the Duke of Bedford that a Whig cabinet ought to be prepared in advance." ${ }^{64}$ Lady Lansdowne's advice concerning the future of the existing cabinet was valued by male politicians.

I also talked very freely to Lady Lansdowne and she is quite right in all respects. She feels that if we are dismissed Lord Lansdowne will be relieved from an arduous and difficult position, but she is quite resolute in thinking that the greatest evil will be to show any want of self confidence in such an emergency. ${ }^{65}$

Mrs. Arbuthnot was frequently consulted for her advice on cabinet formation.

I saw Lord Bathhurst yesterday and he talked with me as to how the offices should be filled [after the departure of the Canningites from the cabinet in 1828]. I told Lord Bathhurst that I knew the Duke [of Wellington] was extremely anxious to have Lord Grey in the Cabinet. But I had remarked that as the King had such strong personal objections to Lord Grey I did not think it would be fair to ask the King to allow him to fill an office. Lord Bathhurst agreed with me. ${ }^{66}$ 
Mrs. Arbuthnot frequently did not agree with Wellington's views. In many instances, like this one, she was able to convince him to see things her way. Mrs. Arbuthnot in her journal stated that it was her advice to approach Palmerston a second time about joining the Wellington cabinet. ${ }^{67}$ At a meeting after Huskisson's death, it was Mrs. Arbuthnot who advised Wellington to offer Palmerston the Colonial office. She advised that wellington choose Lord Clive to be the intermediary as Clive was a friend of Palmerston. ${ }^{68}$ Mrs. Arbuthnot's advising was not always popular. Hardinge said "Mrs. Arbuthnot does indefinite harm by telling the Duke he must come in with the Government exactly as it was, that is, with Arbuthnot." 69

Wilberforce commented on the role of women advising the Prince of Wales. "I am assured that before the Prince determined upon keeping the present ministers, he sent to Mrs. Fitzherbert and Lady Hertford, and they both advised it." 70 Tory women advised the Prince to side against supporting the Whigs. The Tory Duke of Buckingham said "These ladies who were known to exercise the most influence over the Prince were appealed to and are said to have proved zealous advocates of Mr. Perceval." 71

British aristocratic women also advised on the filling of other Cabinet posts. In 1845, Lord John Russell resigned as Prime Minister. Princess Lieven boasted that she 
prevented Lord Lansdowne from obtaining the Foreign office. But she had "in fact absolutely no political influence over Grey, sincere was his friendship for her."72 ${ }^{72}$ Trevelyan said Lansdowne turned down the office. Lieven also claimed to have persuaded Lord Grey to give the Foreign office to Palmerston in 1830. This, Trevelyan said,

has generally been disbelieved, though more on the grounds of the unlikelihood that Palmerston would connive at her activities than from any lack of evidence that she put considerable pressure on Grey.

Lady Palmerston, wife of the 2nd Lord, wrote to her husband concerning the position of the Lord Lieutenant of Ireland. "Why did not Pitt send Lord Gower? Lady Sutherland [wife of Lord Gower] has all the grace and manner to make her admired in public. I see I ought to be consulted." Lady Palmerston thought she knew better than Pitt and had a right to say her mind; that her opinions were valuable. She felt that Lady Sutherland was more important than her Lord Gower, her husband, for the position. ${ }^{74}$

In 1822, Lord William Russell consulted Mrs. Canning over the position of the Governor-General of India, that Canning had held during the 1820s. Lord William Russell wanted the position himself. Charles Greville described what occurred. Lord William,

saw Mrs. Canning, and being anxious to acquire information concerning the Indian appointment, he told her that she had an opportunity of obliging him by telling him anything she knew concerning 
it. She answered very quickly and in a very bad humor, -Oh, it is all settled; Lord Amherst is appointed.' She then put into his hand a letter which Canning had received that morning from the Duke of Portland, declining his offer of the Private Secretaryship for John and George, alleging as a reason the hostile politics of Lord William and Titchfield. Mrs. C. said that she had no idea that they would not have supported Canning, that she was aware they differed on some matters of minor importance, but that she had imagined their general opinions to be similar. That she conceived Lord William's opposition to have been directed against Lord Londonderry, and that it would have ceased with his death.

Years later Canning's daughter, Lady Clanricarde, was also advising others concerning the India post. "Lady Clanricarde tells me that she has given you contrary advice, and her opinion is of immense value." ${ }^{76}$

\section{INDIVIDUAL WOMEN POLITICAL ADVISORS}

There were five British aristocratic women who excelled in their role of political advisor--Georgiana, the excellent mediator among the Whig factions; Lady Melbourne, the channel to the Prince of Wales; Lady Cowper, the advisor most successful in all aspects of political advising; Princess Lieven, the foreigner with so much impact on English political life; and Mrs. Arbuthnot, Tory advisor and channel to the Duke of Wellington. Through a detailed study of their political advising activities--intermediary, political whip, 
and issues advisor, we can see how effective they were at controlling the flow of political information.

of all the politically active British aristocratic women, Georgiana exemplified the political power and influence women had in mediating between individuals and factions. She was the "active mover in all the cabals of her day." "The lifeblood of the society in which she moved, flowed from the heart of politics."78 It was she who kept the Whig Party together, especially through the numerous quarrels of Fox and Sheridan, Burke and Fox, and Grey and Brougham During the last decades of the eighteenth century, there were numerous Whig factions. The two main whig factions were the followers of Charles James Fox and the followers of Richard Brinsley Sheridan. The two factions did not like each other. "As the Duchess of Devonshire recorded [in her diary], the eccentric jealousies of these two highly talented men often led them into embarrassingly juvenile quarrels. "79

It was Georgiana who settled these quarrels. She was tremendously important as a fence mender. She brought the Cavendish family, including her husband and her brother-inlaw, the Duke of Portland, back into Fox's corner. In his history of the Whig Party, Lord Holland said it was Georgiana who was responsible for getting the Duke of Devonshire back 
to Fox's connection after the Whig Party split over the views of the French Revolution in the 1790s.

In smoothing the way, if not to political reconciliation, to renewed habits of familiarity and friendship with Mr. Fox, the Duchess of Devonshire was not a little instrumental. In a very short time after the feverish and unnatural separation in 1793, she had the satisfaction to see most of that society, of which she was the ornament and soul, reunited in the support of $\mathrm{Mr}$. Fox, for whose transcendent genius, generous character, and open temper (so congenial with her own), she had always felt and expresses the warmest and not unaffected enthusiasm.

Georgiana attempted to mediate the quarrel between Edmund Burke and Fox. In the famous quarrel between Burke and Fox, the Duchess of Devonshire took the office of mediator. Burke had attacked Fox in the Commons, and Fox broke down and cried there in the House. "But the quarrel was never reconciled, not withstanding the good offices of the Duchess of Devonshire, the friend of both parties." 81

Georgiana mediated the quarrel between sheridan and Grey. In a letter to Lady Melbourne in 1802, the Duchess wrote that she was very concerned. She feared that Lord Grey might be too upset over the attack by Sheridan at a Whig club banquet. Sheridan accused Grey of deserting the cause. Georgiana accused Lady Holland of stirring up the situation. Georgiana said,

I am as anxious as it is possible to be. I am convinced that in the first instance, no one considered the attack to affect Mr. Grey, but that it was a maneuver of Lady Holland and Tierney to make mischief and shelter the latter. I have 
proof of this because Lady Holland, when she wrote my sister [Lady Bessborough] the account of the speech [Sheridan made about Grey] said it was very illnatured to Tierney. Now had not the other been an after thought she would have mentioned it then. I have written to him telling him what I thought Tierney had a mind to draw him into the scrape by making him suppose that Sheridan had meant him.

During the Regency Crisis of 1788-89, Georgiana mediated on a daily basis between the numerous Whig factions swirling around the Prince and King. All factions met at Devonshire House, under her supervision.

Georgiana had also mediated between the Prince of Wales and his father. In 1783 the Prince turned 21 and wanted to establish his own household. She soothed away ill-feelings on both side during the negotiations over funding of the Prince's new household. ${ }^{83}$

Croker related an incident that showed the political power of Georgiana; someone attempted to bribe her. When Fox was setting up his new cabinet in 1806, he wanted Adair as his Undersecretary of State. Adair had married a Frenchwoman. Croker said,

I happened to call one morning on the Duchess of Devonshire, whom I found evidently discomposed and agitated. As I knew she had pecuniary difficulties I fancied that this was some trouble of that nature. But I soon saw that it was something of a different character. She exclaimed two or three times that the most shocking, the most cruel thing had just happened to her. At last she told me that Mrs. Adair had been with her and had offered a bribe--a bribe of 10,000 pounds down and as much more whenever she might want it-if she would communicate the Cabinet secrets she could not fail to be acquainted through her 
intimacy with all the leaders of the Government. She said that she had dismissed the negotiatrix abruptly and had set off instantly for Mr. Fox to tell him of the circumstance.

Devonshire House was the center of political flow in the Whig world. From Devonshire House that group knew everything before it happened, and when it happened, knew precisely how much it was going to signify. Georgiana, herself was the center of this information flow at Devonshire House. One way she obtained information was through her brother, Lord Spencer, who was appointed in 1794 as First Lord of the Admiralty. Lord spencer was a member of the Portland Whigs who went over to the government side during the temporary split with the Foxite Whigs. Georgiana herself eventually reunited the two factions back together.

From October 1788 to March 1789, George III was temporarily insane, thus setting off the Regency Crisis of 1788-89. Georgiana was at the center of the riotous political activity surrounding the Prince of Wales and the possibility of the Whigs returning to power. ${ }^{85}$ She obtained and disseminated information from all sides of the problem. The Prince of Wales confided in her. Her friend the Duke of Richmond kept her informed of the opinions and actions of the court party. The Whig politicians from all factions hovered at Devonshire House. She was "deeply involved in the preparations of Fox and the Prince of Wales" to establish the regency. ${ }^{86}$ She kept a diary of the hectic months that is the 
basis of historians' knowledge of the time period. So great were her political sources that her diary has become the main source of information for historians of this Crisis. She sent the daily entries of her dairy to her mother in order to keep her informed. Lady Spencer replied, giving her back information.

One of the reports here is that you have advised the Prince not to accept anything but the sole regency without any limitation. This advice was as politic as it was good, for it would conciliate the affectations of the nation and greatly weaken the power of the present Ministry.

Lady Melbourne was one of the most important political advisors of her time, male or female. She was the foremost advisor to the Prince of Wales, later George IV. She was the channel through which other politicians could influence the Prince. Throughout her adult life, she screened access to him. Lady Melbourne retained her high level of political influence over the Prince, even once the Whigs were out of favor with him. He continued to visit Melbourne House, even with a Tory Prime Minister, and he kept her husband, Peniston, as a member of his royal household.

Lord Albemarle wrote a long letter to her urging that she push the Prince towards Catholic Emancipation. However, when Lord Albemarle wrote to Lady Melbourne, she was in the country. She could hardly travel to London to ask the Prince without a reason, because "had he suspected her of any 
attempt to influence him, he might have refused to see her." Airlie suggested that Lady Melbourne used the opportunity of asking his support for his influence in her son's diplomatic career, as an excuse to push for Catholic Emancipation. ${ }^{88}$ She was able to make many political changes through her influence with the Prince. For example, Airlie noted that Lady Melbourne was able to change some policies in the British army. ${ }^{89}$

Lady Cowper was another very influential political advisor. The historian, Mandler, recently stated he believed it was Lady Cowper who was responsible for bringing liberalism into the Whig party. ${ }^{90}$ It was well-known that Palmerston relied on Lady Cowper and acted on her judgment. It was also well-known that her brother, Melbourne, "had few political thoughts apart from her and had an equally high estimate of her discernment and sagacity. He too asked and acted on her counsel." ${ }^{91}$

Lady Cowper was aware of her political influence. Referring to Wellington, after he announced his resignation from office in 1827, she commented on how she would have advised him differently (and in typically Lady Cowper fashion).

I would give anything to see him in his place again and contented. I am so fond of him but he has not acted wisely on this occasion. If I had been at his elbow I should have prevented him [from resigning]. What a pity that he was not in 
love with me instead of Mrs. Arbuthnot. The moral of the story is that no man should be in love with a foolish woman. If he is ever so clever himself, he is sure to be ruined by it. ${ }^{9}$

Lady Cowper acted as an important intermediary between the world and Palmerston. People asked her to intercede for them with Palmerston. Her house was a center of Whig society and a "barometer of political life. In her drawing room decisions were made which affected the future of Europe." She could "soften the bitterness his acts provoked. She conciliated to render the Opposition less hostile." ${ }^{93}$

Lady Cowper also mediated between political factions. She mediated between the Canningites and the supporters of Wellington. Lady Cowper and Huskisson were a formidable team in working to overcome George Lamb's lingering doubts about joining Wellington's administration. ${ }^{94}$ Lord Brougham sarcastically referred to her as "our excellent Countess Emily" for her efforts to get the two factions together after the death of Huskisson." ${ }^{95}$ Lady Cowper urged her brother, Beauvale, home to help mediate between her husband, Palmerston, and Russell over foreign relations of Britain and Turkey. ${ }^{96}$ Palmerston left it up to his wife to rebuke Lord John Russell [over his stance on the Corn Laws] and tell him that she was sure the Protectionists were honest and "would have given you a sincere support if you could have accepted a compromise.

Lady Cowper mediated between Palmerston and Princess Lieven. In 1830 the British Government wanted Stratford 
Canning to be Ambassador to Russia. But Russia, and Princess Lieven, did not approve of him. Palmerston pushed ahead and got the King's approval of Stratford Canning's appointment. Princess Lieven urged Lady Cowper to send her brother, Frederick (ambassador at Vienna) instead. Lady Cowper attempted to smooth things over between Palmerston and Princess Lieven. She invited them both out to Panshanger and tried to get Frederick to move to St. Petersburg. Her mediation failed, and the Lievens were recalled to Russia in disgrace. ${ }^{98}$

Lady Holland described Lady Cowper's mediating style.

There has been a very serious rumpus among Ministers and King, which was made up by Lady Cowper, the first time she has openly appeared in a political strife. People do not guess why she appears as a peacemaker, because she never seemed to like the Duke of Wellington. And her son, by his resignation shown that he dislikes him.

Charles Greville perceived Lady Cowper to be the spokesperson in the Palmerston family. In 1842,

She talks a great deal more than he does, and it is easy to see, through her graceful, easy manner and habitual urbanity how impatient they are of exclusion from office, and how intolerant of any dissent from or opposition to his polity or opinions .

Southgate said in 1853, it was Lady Cowper who made it known that overtures for a new political office would be well received. ${ }^{101}$ There was a "method in her madness. She could do what Palmerston could not." 102 
Princess Lieven, the wife of the Russian ambassador to Britain, was the most adept at controlling the flow of information of political information both within England and between England and Europe. Metternich called her, the "Mother of Diplomats." ${ }^{103}$ Next to Lady Melbourne, she was the most highly skilled political advisor England has ever seen. Princess Lieven was an astute intermediary. It was she who negotiated a truce between Lady Castlereagh, wife of the Prime Minister, and Lady Conyngham, the mistress of the Prince of Wales, then King George IV. They refused in 1820 to sit down at the same dining table. ${ }^{104}$

Most biographers (all of male gender) of Palmerston, Wellington, and Grey almost entirely dismiss her influence with their subject. It was as if it was too impossible for these historians to accept. Palmerston's biographer stated that Grey only allowed her believe "she called the tune for leading British politicians" and that she only "amused" Palmerston. ${ }^{105}$ Lord Grey's biographer, Smith, believed her influence "fell far short of her imagination." He did not believe that she influenced Grey to appoint Palmerston to the Foreign office in 1830. But Smith based his evidence for this belief only on "the grounds of the unlikelihood that Palmerston would connive at her activities than from any lack of evidence that she put considerable pressure on Grey."106 Yet these politicians visited her almost every day, and wrote 
to her, when separated. How could she not influence them? More importantly the perception of her in contemporary society was that she was a very influential political advisor.

The most prominent political advisor of the early nineteenth century was Mrs. Arbuthnot. She, like Lady Cowper, was very aware of her political advising role. She was proud of her ability to control politicians. To Lady Shelley she stated proudly "We shall keep the Duke of Rutland in order I hope and believe." ${ }^{107}$ The Duke of Rutland wrote acknowledging her political influence. "I take an excessive interest in all your letters. How anxiously they interest me."10 Mrs. Arbuthnot prided herself on forcing Wellington to think through his policies more clearly.

I wrote a few days ago to the Duke, telling him I thought his advise to Palmella and Lord Beresford was very good. But I wanted him to explain how he made it accord with his desire in the summer to grant the troops Palmella wished for. He answers me that the thing does require explanation and that it is very like me to have desired to have it.

Mrs. Arbuthnot enjoyed the ability she had to make Wellington and others rely on her judgments. "The affair of the Lord High Admiral is ended very satisfactorily. The Duke took my advice very good-naturedly." ${ }^{110}$ The editor of her letters wrote "what is even more unexpected is that he [Wellington] 
is ready to listen to and be influenced by a woman's views on political questions."111

The Duke of Wellington almost invariably discussed what happened at cabinet dinners and meetings with Mrs. Arbuthnot. Mrs. Arbuthnot's journals were full of occurrences of Wellington talking about high level governmental information with her. We can also see in these journals a sense of pride in herself at these confidences; she is proud of herself. In 1826 when Wellington was in Russia, Mrs. Arbuthnot wrote to him "twice a week [with] all the news I can collect for him. I dine out most days and go out every evening [to get the news]." 112 Mrs. Arbuthnot also saw Wellington's private correspondence with Canning.

On the tenth the Duke [of Wellington], showed us some memoranda he had written and sent to canning upon the question, [the topics were] first of his language in Parliament and secondly of the consequences of our going to war.

In 1829, Mrs. Arbuthnot wrote "The Duke has sent me today a paper he has written upon" the Turkish/Russian Treaty. ${ }^{114}$ Wellington also sent Mrs. Arbuthnot copies of letters he sent to Peel and other cabinet members. ${ }^{115}$

Mrs. Arbuthnot was a frequent spokesperson for the Duke of Wellington. She was his most prominent advisor and London society perceived her as such. "All people believe that you are speaking the Duke's sentiments."116 Even she herself acknowledged her influence with the Duke. "On the tenth [of 
February] the Duke, who seems never to do anything without communicating with $\mathrm{Mr}$. A. and me, showed us some memoranda." 117 In 1828 she advised the Russian ambassador it was important that he speak to Wellington about the concerns he had with the situation in Turkey. She told the ambassador what wellington would say. She said

I had a long visit of two hours from M. de Lieven the day after he received the Turkish manifesto from St. Petersburg. I urged him as strongly as I could to see the Duke. He told me that if I would only tell him that such as step on his part would be agreeable to the Duke, he would take it without delay. I said I could not say I knew it would be agreeable to the Duke. [But] I could not doubt that he would rejoice in any step. ${ }^{118}$

Mrs. Arbuthnot tried to smooth things between the Duke of Wellington and the Duke of Clarence in 1828.

I suggested this conciliatory policy, he [Wellington]. . . is to see the king about it all on Monday and I shall see him on Sunday and try to prevail on him to settle the thing, if he possibly can without yielding the point.

Mrs. Arbuthnot also attempted to mediate between Lord Londonderry and wellington.

Lord Londonderry is furious that he and his son [Viscount Castlereagh 1805-1872] are entirely passed by. I met him at dinner yesterday at Prince Leopold's and sat next to him. He entertained me the whole time with these complaints. I spoke to the Duke about it after dinner, but, however, he got out of temper about it so I shall say no more. I certainly think it a great pity he does not employ Lord Castlereagh. 
She chastised Wellington for his loose tongue with other women, in this case with Princess Lieven.

It is true. I therefore wrote and told him [Wellington], pointed out to him that her gossip and character did him much harm as Lord Anglesey's folly. That she did not really value his friendship and confidence for their own intrinsic worth, but merely as they gratify her to boast to her 500 particular friends. And I entreated him, for the present at least, to keep her at arm's length. I expected he would be very angry but I did not mind, for her talking really does him serious mischief. But, on the contrary, he wrote me word he was much obliged to me for telling him.

He protested he had never uttered to her, at least not confidentially, upon the subject, but owning that any communication with such a woman was dangerous.

\section{CONCLUSION}

As the contemporary diaries, letters, and journals demonstrated, the major male political leaders depended upon the political advising role of British aristocratic women. They frequently and continually brought information to women and sought information from women. British aristocratic women were not shut out of the political establishment. Instead they created and sustained an information network upon which the socio/political structure depended. ${ }^{122}$ Although British aristocratic women did not necessarily originate the political information, it was the women who controlled this flow of political currency. They did this through the four functions of their role of political 
advisors--intermediaries, political whips, issues advisors, and political office advisors.

The contemporary literature makes it obvious that this role of political advisor was both accepted and depended upon. Contemporaries accepted this role of British aristocratic women. Perhaps this role was the fundamental (and perhaps too obvious to a late twentieth century historian) role upon which British aristocratic women derived all their political power and influence.

We tend to define political value by comparing female activities to male activities. Do women's actions have to be like men's to have value? Do they have to be different from men's to be unique?. Do some women's political activities, such as intermediary, have less value because it is part of the traditional female role of peacemaker? Contemporaries did not think so. I believe at times we are placing value on political activities, based on standards from our own time. Contemporaries placed great value upon women's political actions, that we, in our own time, consider not valuable. 
ENDNOTES FOR CHAPTER IV

\begin{abstract}
${ }^{1}$ Most notably are the following: the diary of Georgiana Duchess of Devonshire in Sichel, Sheridan; Lascelles, Life of Charles James Fox; Smith, Lord Grey; George III, Later correspondence. Georgiana's was the only reliable primary source available to historians of the late eighteenth century. Mrs. Arbuthnot's journal has been used heavily in most studies of Wellington, Peel, the Reform Bill, and Catholic Emancipation, Arbuthnot, Journals of Mrs.
\end{abstract} Arbuthnot.

${ }^{2}$ J. C. D. Clark, English Society 1688-1832: Ideology, Social structure and Political Practice During the Ancient Regime (Cambridge, England: Cambridge University Press, 1985), and Southgate, Most English.

${ }^{3}$ Jeremy Black, pitt the Elder (Cambridge, England: Cambridge University Press, 1992); John Ashton Cannon, Fox-North Coalition: Crisis of the Constitution, 1782-84 (Cambridge, England: Cambridge University Press, 1969); John Prest, Lord John Russell; Frank O'Gorman, The Whig Party and the French Revolution (London: Macmillan, 1967; New York: St. Martin's Press, 1967); Ellis Archer Wasson, "The Great Whigs and Parliamentary Reform, 1809-1830," Journal of British Studies 24 (1985); and Loren Dudley Reid, Charles James Fox: A Man for the People (Columbia: University of Missouri Press, 1969) used many letters written by women on politics to describe political events.

${ }^{4}$ We have two volumes of their correspondence published, but much was severely edited. See Leveson Gower, Earl Granville, Lord Granville Leveson Gower, Private Correspondence 1781-1821, ed. Countess Castalia Granville, 2 vols. (London: John Murray, 1916).

${ }^{5}$ Arthur Aspinall, ed., Formation of Canning's Ministry, February to August 1827, ed. from Contemporary Correspondence, Camden Miscellany 3 rd Series, vol. 59 (London: Royal Historical Society, 1937), especially Letters \#138, \#149, and \#116. Harriet's husband was a Canning supporter]. A day earlier she wrote to Arbuthnot "Remember I have been passing two days and evenings with two great Canningites such as Francis [her husband Francis Leveson Gower] and Mr. Denison. Unless therefore I have some facts and, particulars to argue with them about I shall run great risk of becoming a Canningite too. As it is I think I have made a very good fight of it." Arbuthnot responded with details on April 18th, thanking Harriet for her request for 
the information and her request for more information. "Many Thanks indeed for your interesting letter. It is really kind of you to write me all these details. You may be sure that I will not mention to a creature that I have heard from you on the subject." Aspinall, Formation, p. 11.

${ }^{6}$ The editor of the Elliot correspondence commented on the political role of letters, "The political letters gave us the deliberate opinions of a certain school of politicians. In Lady Malmesbury's [sister of Lady Elliot] we are reminded of the circumstances which were daily molding these opinions.

She wrote as they reached her, the reports of the hour, reports that often were false or exaggerated, yet, accepted as authentic in the political society of London. In other words, we learn the facts, real or so-called, which were exciting the passions of a whole people." Emma Eleanor Elliot Murray Kynynmound, the Countess of Minto, editor of Elliot, Life and Letters, $2: 36$.

${ }^{7}$ British aristocratic women often were the political spokespersons of their families. Lady Lyndhurst was especially outspoken about the political interests of her family. Lord Holland, in 1833, reported a "strange rumor" that Lord Lyndhurst was to be Prime Minister, not Chancellor, and head of the Conservative Party if the Whigs fell. Holland found this "notion so absurd that I should not record it here if some ambiguous phrases that dropped from Lady Lyndhurst did not so far corroborate the suspicions as to show that preference of a political to a judicial station had trotted through her head very recently." Lord Holland's Diary, 26 July 1833, Holland House Diaries, p. 235.

81842, Greville, Greville Memoirs, p. 178.

'James Abercrombie to the Earl of Carlisle, $31 \mathrm{July}$ 1827, Aspinall, Formation, p. 275.

${ }^{10} \mathrm{Gash}$, Sir Robert Peel, p. 109.

${ }^{11}$ Lascelles, Life of Charles James Fox, p. 307.

${ }^{12}$ Horace Walpole to Mann, 2 Dec 1768, Horace Walpole's Correspondence, $9: 74$.

${ }^{13}$ Letter from the King to Mrs. Arbuthnot, 21 May 1829, in Arbuthnot, Journals of Mrs. Arbuthnot, $2: 273$.

${ }^{14}$ Ethel Colburn Mayne, A Regency Chapter: Lady Bessborough and Her Friendships (London: Macmillan, 1939), pp. 221-222. 
${ }^{15}$ Trevelyan, Lord Grey, p. 127. Lady Elizabeth Foster described the situation as "I am afraid Lady Holland tries already to do mischief and make jealousies." Dorothy Margaret Stuart, Dearest Bess: The Life and Time of Iady Elizabeth Foster, Afterwards Duchess of Devonshire, From Her Unpublished Journals and Correspondence (London: Methuen, 1955), p. 138 .

${ }^{16}$ This was during the height of her political power, with the return to the premiership of her uncle, Peel, "politicians sought her advice, princes and ambassadors begged to be introduced to her." Haslip, Lady Hester, p. 45. Late in her life in England, the "Dukes of Cumberland and York still sought her advice and listened to opinions. She was no longer the fashion, but young politicians still thought it worth while to ask her advice." Haslip, Iady Hester, p. 63 .

${ }^{17}$ Quoted in Mitchell, Holland House, p. 32.

${ }^{18}$ Lee, Wives, p. 112 .

${ }^{19} 25$ Oct 1828, Arbuthnot, Journals of Mrs. Arbuthnot, $2: 216,221$.

${ }^{20} 3$ Jan 1789, Elizabeth Sheridan, Betsy Sheridan's Journal, ed. William LeFanu (New Brunswisk, NJ: Rutgers University Press, 1960), p. 142.

${ }^{21}$ For example the 18 Apr 1865 letter to Gladstone quoted in Southgate, Most English, p. 536. Lady Caroline Fox wrote a political testimony memorial for Talleyrand, as a favor to her brother Lord Holland. He published it under his own name. Ilchester, Chronicles, p. 127.

${ }^{22}$ Herbert Van Thal, ed., The prime Ministers, intro. by G. W. Jones (London: George Allen \& Unwin, 1974), p. 117.

${ }^{23}$ For information concerning Lady John Russell and the Edinburgh Letter see Francis Shelley, Diary, 2:272-289. For information concerning Lady Shelley and the Wellington letter see Prest, Lord John Russe11, p. 201-209.

${ }^{24} 9$ Nov 1826, Arbuthnot, Journals of Mrs. Arbuthnot, 2:54. See also Arbuthnot, Journals of Mrs. Arbuthnot, 2:207.

It is interesting to note that one of these dispatches from Russia was written by a woman, Lady Heytesbury, writing from Odessa. 
${ }^{25}$ Bourne, Palmerston, p. 441.

${ }^{26} 1810$, Sonia Keppel, Sovereign Lady: A Life of Elizabeth Vassal. Third Lady Holland, With Her Family (London: Hamish Hamilton, 1974), p. 183.

${ }^{27}$ Keppel, Sovereign Lady, p. 140.

${ }^{28}$ Mitchell, Holland House, p. 278.

${ }^{29}$ Charles James Fox to Georgiana 1805, Vere Foster, ed., Two Duchesses: Family Correspondence of and Relating to Georgiana Duchess of Devonshire and Elizabeth Duchess of Devonshire 1777-1869 (London: Blackie, 1898), p. 263. Georgiana was still politically important this late in her life--one year before her death when she was so ill.

${ }^{30}$ Horace Walpole to Lady Ossory, 9 Feb 1787, Horace Walpole's Correspondence, 33:560.

${ }^{31}$ Wellington to Lady Shelley, 24 Sep 1831, Shelley, Diary of Lady Shelley, 2:207. In a letter to Wellington she told him the results of her efforts, "As you were lately interested in knowing Lord Gage's sentiments, I think you may like to know what he has now determined upon. He has given his proxy to Lord Wharncliffe [a supporter of Wellington's position]. Lord Kinnoull, whom I met at Firle [Seat of Lord Gage in Sussex], has also given his proxy to Lord Wharncliffe. I trust that your views coincide with theirs. But even if they do not, I think that Lord Gage, as he approved of the first rejection [of the Reform Bill] by the Lords, must be very hard to persuade to vote again against the Bill." Lady Shelley to Wellington, 15 Jan 1832, Diary of Lady Shelley, $2: 210$.

${ }^{32} 8 \mathrm{Feb}$ 1829, Arbuthnot, Journals ef Mrs. Arbuthnot, $2: 238$.

${ }^{33}$ Marjorie Villiers, The Grand Whiggery (London: John Murray, 1939), p. 38.

${ }^{34}$ Blackburne, Ladies' Chain, p. 107-108.

${ }^{35}$ Elizabeth Vassall Fox Holland, Elizabeth Lady Holland to Her Son 1821-1845, ed. Earl of Ilchester (London: John Murray, 1946), p. 94 .

${ }^{36}$ The clause was an amendment to regulate the warehouse system in the Corn Law Bill. 3 June 1817, Arbuthnot, Journals Mrs. Arbuthnot, $2: 124$. 
${ }^{37}$ Edward Porritt, The Unreformed House of Commons. Parliamentary Representation Before 1832, 2 vols., reprints of Economic Classics (London: Cambridge University Press, 1903; reprint ed., New York: Augustus M. Kelley, 1963), 1:580. The author does not give any examples of this occurring. He only refers to the House of Commons Journals as a source for further information on this aspect of political whip.

${ }^{38}$ There is a vast amount of material describing how women gave political advice to males, who were not their husbands. You would have expected a large amount of examples of women advising their husbands, but there was so much more.

What also was interesting was the large numbers of examples of women advising other women on political matters. Women talked politics frequently with other women.

${ }^{39}$ Keppel, Sovereign Lady, pp. 302-303.

${ }^{40}$ Richard Plantagenet Temple, Duke of Buckingham and Chandos, Memeirs of the court of England During the Regency 1811-1820 From Original Family Documents, 2 vols. (Iondon: Hurst \& Blackett, 1856), 1:127.

${ }^{41}$ Holland, Lady Holland to Her Son, p. 70.

${ }^{42}$ Bourne, Palmerston, p. 298.

${ }^{43}$ She was Brougham's step daughter. She was married to Sir Alexander Malet of the delegation at The Hague. It was she who obtained the diplomatic position for her husband, by asking Brougham to ask Palmerston. Bourne, Palmerston, $p$. 459 .

${ }^{44}$ Mitchel1, Holland House, p. 279.

${ }^{45} 27$ December 1831, Holland, Helland House Diaries, $p$. 102. Kriegel commented on Lady Grey urging an increase in the peerage. I "drove from Richmond to Lord Grey's Downing Street and urged him as did Lady Grey and Lord Durham not to trust too implicitly to the prospects of converts to reform in the House of Lords." 12 Feb 1832, Holland, Holland House Diaries, p. 128.

${ }^{46}$ Elizabeth Vassall Fox Holland, Journal of Elizabeth. Lady Holland 1791-1811, ed. Earl of Ilchester, 2 vols. (London: Longmans, 1908), 2:94-95. 
${ }^{47}$ The editor believed that "ladies then exercised more political influence, though they claimed it was less." "The days, perhaps, have gone by when a political chieftainess can assemble the heads of her party in a dressing room." Sichel, Sheridan, $2: 59$.

${ }^{48} \mathrm{July} 1792$, Portland MSS. PWG 130 quoted in Mitchel1. Holland House, p. 172.

${ }^{49}$ A. J. P. Taylor, "Lord Palmerston," History Today 41 (1990):16.

${ }^{50} 9$ Apr 1829, Arbuthnot, Journals of Mrs. Arbuthnot, $2: 267$.

${ }^{51}$ Duke of Rutland to Mrs. Arbuthnot, 5 Mar 1827, quoted in Aspinall, Eormation, p. 32.

${ }^{52}$ Bourne, Palmerston, pp. 312, 315. See also Gash, Sir Robert Peel, p. 218. 90 .

${ }^{53} 26$ Oct 1796, Glenbervie, Lord Glenbervie's Diary, p.

${ }^{54}$ Mrs. Canning to the Duke of Portland, 20 Apr 1827, quoted in Aspinall, Formation, p. 155.

${ }^{55}$ Arthur Aspinall and E. Anthony Smith, English Historical Documents, $1783-1832$ (New York: Oxford University Press, 1959; London; Oxford University Press, 1959), p. 97.

${ }^{56}$ Prest, Lerd John Russe11, p. 338.

${ }^{57}$ Arbuthnot, Journals of Mrs. Arbuthnot, $2: 338,22$ Feb 1830 .

${ }^{58}$ Leslie G. Mitchell, Charles James Fox and the Disintegration of the Whig Party, 1782-1794 (London: Oxford University Press, 1971), p. 32. The author further believes that this resignation was a significant factor in the disintegration of the Whig party. As a humorous aside, in 1836, Lady Lyttelton commented that nothing could remove him from office except the large amounts of food he ate, "which he does his best to revolutionize his stomach with every day." Sarah Spencer, Lady Lyttelton, Correspondence of Sarah Spencer, Lady Iyttelton 1787-1870, ed. Maud Mary Wyndham (London: John Murray, 1912), p. 285.

${ }^{59}$ Lascelles, Iife of Charles James Fox, p. 322. 
${ }^{60}$ Betsy Sheridan to Alicia Le Fanu, 22 Dec 1788, especially discusses the Duke of Northumberland for Ireland, Betsy Sheridan's Journal, p. 139.

${ }^{61}$ Bourne, palmerston, p. 294.

${ }^{62}$ But the author said "There was no evidence to support this." Hawes, Henry Brougham, p. 79.

${ }^{63}$ Quoted in Arthur Aspinall, Lord Brougham and the whit Party, pub. no. 179 (Manchester, England: Manchester University Press, 1927; reissued 1939; reprint ed., Hamden, CT: Archon Books, 1972), p. 218.

${ }^{64}$ Aspinal1, Lord Brougham, p. 71.

${ }^{65}$ James Ambercromby to the Earl of Carlisle, 3 Aug 1827, Aspinall, Eermation, p. 277.

${ }^{66} 27$ March 1828, Arbuthnot, Journals of Mrs. Arbuthnot, $2: 178$.

${ }^{67}$ Arbuthnot, Journals of Mrs. Arbuthnot, $2: 387$.

${ }^{68}$ Mrs. Arbuthnot said it did not matter that Clive was "'deaf as a post and not very bright' because he would never have to explain it all to Parliament" in Journals of Mrs. Arbuthnot, 2:387-389. Southgate said "the second approach to Palmerston was made at her suggestion and was a cabinet decision. The emissary was Lord Clive." Southgate, Mest English, p. 569, note 13 .

${ }^{69}$ Iord Ellenborough Diary, 26 Feb 1831, Aspinall, Three Early, p. 61 .

${ }^{70}$ Life of Wilberforce quoted in Buckingham and Chandos, Memeirs of the Court of England, 1:30-31.

${ }^{71}$ Buckingham and Chandos, Memoirs of the court of England, 1:25.

${ }^{72}$ Trevelyan, Lord Grey, p. 243.

${ }^{73}$ "His association with her does suggest a degree of indiscretion and misjudgment, fostering suspicion, however unjustified, of the nature of the relationship and its political influence." Smith, Lord Grey, p. 282. The political relationships of Princess Lieven have not been explored by historians. 
${ }^{74}$ Lord Cowper to Lord Palmerston, 16 March 1796, Brian Connel1, Pertrait of a Golden Age: Intimate Papers of the Second Viscount Palmerston, Courtier Under George III, $1739-$ 1802 (Boston: Houghton Mifflin, 1958), p. 372.

${ }^{75} 24$ Nov 1822, Greville, Greville Memoirs, p. 15. It is interesting to not how Charles Greville believed that Mrs. Canning was so politically important and valuable.

${ }^{76}$ Concerning Canning's staying in India office. Lord Granvilie to Lord Charles Canning, 26 July 1860, in Iife of Granvilie, $1: 386$.

${ }^{77} 16$ Jan 1837, Thomas Raikes, A Portion of the Journal Kept by Thomas Raikes from 1831-1847, 4 vols. (London: Longmans, Green, 1856-57), 3:105.

${ }^{78}$ Villiers, Grand Whiggery, p. 5.

${ }^{79}$ Mitche11, Charles James Fox, p. 141.

${ }^{80}$ Holland, Eurtber Memoirs, 1:78.

${ }^{81}$ In the 1780s, Grace wharton and Philip wharton, The queens of Society, 2 vols. (Philadelphia: Porter \& Coates, 1861), 1:140. See also Sichel, Sheridan, 1:72.

${ }^{82}$ Georgiana Duchess of Devonshire to Lady Melbourne, Feb 1802, Airlie, In Whig society, p. 26. This was written by a woman to another woman. Georgiana showed here great political insight into George Tierney. Tierney was against Pitt and tried to prevent the whig secession in 1798. But his "determination to make mischief was well known." Airlie, In Whig Society, p. 25.

${ }^{83}$ Cannon, Fox-North Coalition, p. 98. Wraxall went on to comment about the Duchess of Gordon, "Few women have performed a more conspicuous part, or occupied a higher place than herself, on, the public theater of fashion, politics, and dissipation." Nathaniel W. Wraxall, Posthumous Memoirs of His Own Time (Philadelphia: Carey Lea \& Blanchard, 1836), p. 331 .

${ }^{84}$ Mrs. Adair had previously been mistress to Napoleon's minister, Andriossy. John Wilson Croker, in his journal of 1825, described this incident that took place in 1806, The Croker Papers: The correspondence of John Wilson Croker, Secretary to the Admiralty From 1809-1830, ed. J. Jennings (London: John Murray, 1884; reprint ed., New York: AMS Press, 1972), 1:293-294. 
${ }^{85}$ She set the political fashion statement by wearing a Regency Cap to all fashionable events. Neville Blackburne, Ladies Chain (Iondon: Falcon Press, 1952), p. 96.

${ }^{86}$ Lewis, "Political Behavior," p. 257.

${ }^{87}$ Lady Spencer to Georgiana in Masters, Georgiana, Duchess of Devonshire (London: Hamish Hamilton, 1981), p. 140 .

${ }^{88}$ Airlie, In whig Society, pp. 99, 102. Frederick received an excellent diplomatic post out of this, in the typical tidy fashion of Lady Melbourne.

$$
{ }^{89} \text { Airlie, Lady Palmerston, } 1: 18 \text {. }
$$

${ }^{90}$ Mandler, Aristocratic Government, p. 106. "We do not know to what extent Emily was responsible for the change in Palmerston's fortunes. How from being a High Tory minister, he became the Foreign secretary of the Whigs." Lee, Wives, p. 71 .

${ }^{91}$ Lee, Wives, p. 106. Melbourne regularly consulted with her and Frederick, a diplomat "depended upon her letters for information." Lee, Wives, p. 70.

${ }^{92}$ Lady Cowper to Frederick Lamb, 24 April 1827, Aspinall, Formation, p. 179. Lady Cowper was even called upon to organize a royal marriage. In 1853, she negotiated the marriage of a British princess (Princess Mary Adelaide) to Emperor Louis Napoleon. Lord Holland begged her to do so. Ilchester, Chronicles, pp. 398-400.

${ }^{93}$ Lee, Wives, pp. 65, 109.

${ }^{94}$ Ziegler, Melbourne, p. 86.

${ }^{95}$ September 1830, quoted in Ziegler, Melbourne, p. 117.

${ }^{96}$ August 1840, Bourne, Palmerston, p. 599.

${ }^{97}$ Aspinall, Formation, p. 334.

${ }^{98}$ Bourne, Palmerston, pp. 361-363.

9930 Jan 1830, Holland, Lady Holland to Her Son, p. 107. ${ }^{100} 1842$, Greville, Greville Memoirs, p. 178. 
101 "It is not known with what encouragement from her spouse." Southgate, Most English, p. 336. Southgate also included an apt quote from Moncton Milnes [writing to Milnes wife]. "Lady Palmerston writes "Every event in which Palmerston is concerned ends in his standing higher than he did before. There is a fine deluded wife for you, though I think she is right for this once.'" Southgate, Most English, p. 338 .

${ }^{102}$ Lee, Wives, p. 113.

${ }^{103}$ Lucy Poate Stebbins, London Ladies: True Tales of the 18th Century (New York: Columbia University Press, 1952), p. 144 .

${ }^{104}$ Blackburne, Ladies Chain, pp. 173-174.

${ }^{105}$ Southgate, Most English, p. 69.

${ }^{106}$ Smith, Iord Grey, p. 282.

${ }^{107}$ Concerning Catholic Emancipation. Mrs. Arbuthnot to Lady Shelley, 16 Feb 1828, Shelley, Diary of Lady Shelley, $2: 174$.

${ }^{108}$ Duke of Rutland to Mrs. Arbuthnot, 20 April 1827, Aspinall, Formation, p. 136. See also Duke of Rutland to Mrs. Arbuthnot, 2 May 1827, Aspinall, Formation, p. 208. $I: 275$.

${ }^{109} 18$ Nov 1823, Arbuthnot, Jounnals of Mrs. Arbuthnot,

${ }^{110} 10$ Sep 1828, Arbuthnot, Journals of Mrs. Arbuthnot, $2: 207$.

${ }^{111}$ Arbuthnot, Journals of Mrs. Arbuthnot, 1:xiii. Were Mrs. Arbuthnot and Wellington lovers or just good friends? Contemporaries and historians disagree. Almost all the Wellington biographers and some of his contemporaries, notably Peel, thought they were lovers. But the editor of her letters, and Lady Shelley, their close friend, did not. certainly reading these journals we cannot see any signs of affection beyond friendship. But of course we do not know how much these have been edited.

${ }^{112}$ Arbuthnot, Journals of Mrs. Arbuthnot, $2: 14$.

${ }^{113} 12$ Feb 1823, Arbuthnot, Journals of Mrs. Arbuthnot, $1: 214,2: 202-204$. 
$2: 309$.

${ }^{114} 15$ Oct 1829, Arbuthnot, Journals of Mrs. Arbuthnet,

${ }^{115}$ Arbuthnot, Journals of Mrs. Arbuthnot, $2: 204$.

${ }^{116}$ Lord Ashley to Mrs. Arbuthnot, in Aspinall, Formation, p. 140 .

$1: 214$.

${ }^{117} 12$ Feb 1823, Arbuthnot, Journals of Mrs. Arbuthnet,

${ }^{118} 15$ Mar 1828, Arbuthnot, Journals of Mrs. Arbuthnot, $2: 168-170$.

${ }^{119} 28$ Aug 1828, Arbuthnot, Journals of Mrs. Arbuthnot, $2: 204$.

${ }^{120} 9$ June 1828, Arbuthnot, Journals of Mrs. Arbuthnot, 2:192-193. She was however, not always popular. Lady Cowper wrote about the resignation of the Duke of Wellington. "I am sure it must be that villain the chancellor who has led him (Wellington) on and made $a$ tool of him and that fool Mrs. Arbuthnot who has worked him up." 24 Apr 1827, Aspinall, Formation, pp. 177-178.

${ }^{121} 16$ Nov 1828, Arbuthnot, Journals of Mrs. Arbuthnot, $2: 222$.

122 "They got their knowledge from communications of the men who were their relatives and friends, but the method of using it was determined by the women themselves. Lee, Wives, p. ix. Lee, the author, was correct in her statement. Women had their own method of controlling the information flow.

However, I disagree when she implied that it was women who created this control. Contemporary literature demonstrated that this control grew out of the close interaction of politics and society and the small size of the elite, who ran society and politics]. 
CHAPTER V

ELECTORAL INFLUENCE

INTRODUCTION

British aristocratic women actively participated in and strongly influenced British elections during the mideighteenth to mid-nineteenth century. In this chapter on British aristocratic women and elections, after a short discussion of the political structure of Commons elections and sources, I will explore the two major roles of patron and campaigner. For each of these two roles I will discuss the motives behind women's participation (family, political party, and self) and the methods they used, giving examples of both. I will also highlight three of the most influential patrons and campaigners, exploring their motives and methods. Finally I shall discuss British aristocratic women and their activities in the famous 1784 Westminster election. When possible I will let the women speak for themselves, giving their views on their own electoral activities.

Active participation in and influence in elections was an accepted political role for women, one upon which the political system of the time depended. By law, peers were barred from direct involvement in elections to the House of 
Commons. This restriction dates from 1701 when the Commons passed a resolution stating it was illegal to interfere with an election to the lower house as it would be considered a "high infringement of the liberties and privileges of the Commons of England." ${ }^{1}$ While enforcement of the resolution was not uniform, it did restrict the electoral influence and activities of peers. However, since it did not restrict the electioneering of their families, it did increase the electoral influence of peeresses and other women. It became customary for women to exert electoral patronage and to participate directly in elections because their husbands or fathers could not.

This type of activity again reveals the close ties of society and politics as well as the power of aristocratic families. Women's power stemmed from their families, both their own birth families and the families of their spouse. that made it "possible for the females of the family to hand out Parliamentary seats like pieces of candy." ${ }^{2}$ As with other types of patronage, women exerted electoral influence in a similar manner to men, as part of the structural support work of the socio-political power structure. A large percentage of their influence was exercised on the behalf of male family members. Indeed, what makes the famous 1784 Westminster Election so unique was the degree to which women campaigned for party interests, not for family members. 
Patronage in the parliamentary constituencies was an undeniable fact, widely recognized, and even defended by contemporary writers on the grounds that it served a useful function in protecting controversial or particularly important members of the Commons from the problems of electioneering. Almost every constituency contained one or more important families that influenced the representation in parliament. 3 In Porritt's study of the 1832 House of Commons, he said that one half of the early nineteenth century MPs owed their seats to patrons." Aristocratic influence over the lower house remained strong throughout the time period of this thesis. Even the 1832 Reform Bill did not drastically reduce aristocratic influence, and this influence depended upon British aristocratic women. ${ }^{5}$ The process of electoral reform was a gradual one. It took two more reform bills in the nineteenth century (in 1867 and 1884) and two Corrupt Practices Acts (in 1854 and 1883) and the 1872 secret Voting Act to complete the reform process begun in 1832 .

Besides the illegality of peers' campaigning, the powerful electioneering role of British aristocratic women was created by four other features of mid-eighteenth to midnineteenth century political life. First, the size of the electorate was small and most members were elected from constituencies with a small number of electors. Not only did 
each vote count but it could also be easily controlled. Before the 1832 Reform Bill there were 151 boroughs with population of less than 200 people; the majority of Commons Members were returned by boroughs with less that 5,000 inhabitants. As late as 1852,86 members were returned by constituencies with less than 500 electors, and 172 members were returned with constituencies with less than 1000 electors. This was out of a total of 650 members. ${ }^{6}$ As of 1820 the total electorate in English counties was 190,000 and English borough was $123,000 .^{7}$

Second, the electorate expected to be influenced by the aristocracy. Patron control over boroughs and counties was accepted as a normal part of political and social life. Their influence was well documented by contemporaries. A contemporary politician and historian Dod, in his texts on parliament, even listed the most influential patrons in each constituency. ${ }^{8}$

Third, the electoral system, especially certain types of constituencies (such as burgage boroughs) lent itself to opportunities for women to control the nomination and elections of Members of Parliament. There were two types of constituencies--borough and county. They differed from each other in area, size of electorate, and the nature of the qualification of the franchise. While a county had many more voters than a borough, their voters $(40$ shilling 
freeholders), were economically dependent upon their patron, were mostly tenant farmers with little security of tenure, and thus less likely to vote against his or her wishes. The aristocracy dominated county membership. Of the 144 county members, 45 had aristocratic titles and 47 were baronets. ${ }^{9}$

Like county constituencies, many boroughs also were under the control of patrons. Of the 203 English boroughs, 184 had a substantial degree of patron control. Of these 200 or so patrons, 101 were peers or prospective peers. ${ }^{10}$

There were four major types of English boroughs-corporation, scot and lot, freeman, and burgage. British aristocratic women were electoral patrons and participated in elections in all but the corporation boroughs. But it was especially with the latter two types--freeman and burgage-that women exerted the most influence as freeman and burgage boroughs were where that they had "places recognized by custom and by the determination of the election committees." "11

Freeman boroughs varied in size from villages like Aldborough to populous Westminster and Southwark. Smaller boroughs of this type were easily controlled by a patron. ${ }^{12}$ While there were over 71,000 voters in freeman boroughs patrons could still have influence in these boroughs by buying "freedoms" or the right to vote for individuals. Patrons could control freeman boroughs by buying the vote or 
"freedom" of individuals who pledged to support the candidate of the patron. ${ }^{13}$

Burgage boroughs were the most susceptible to electoral patronage. An individual could control the borough through the purchase of the burgages. The largest burgage borough had 270 voters and the smallest was 11 . Women controlled burgage boroughs through ownership of the properties or burgages, through which the franchise was transmitted. That is they owned the majority of properties with burgage rights.

The electoral privileges of women [in the burgage borough] were more direct and more valuable than those in the freeman group, the only other group in which women had any electoral privilege assured to them.

Fourth, actual elections were rare in most constituencies and thus where they did occur British aristocratic women could have greater impact. Due to the control of the electoral patron, only rarely were any elections held in English boroughs and counties. Between 1760 and 1800, including seven general elections, only one tenth of all seats were contested. Many county franchises were not much more frequently contested than the boroughs. Between 1754 and 1790 of the 40 English counties, 12 were never contested and 15 contested only once. However, it is vital to note that the lack of election contests did not signify a lack of political activity or interest. To 
consider as "contested" only constituencies where votes were recorded is misleading. ${ }^{15}$

A contested election was a costly affair, especially in light of the lack of a national party organization. The candidate and his patron had to absorb the costs of all aspects of the elections. It was also difficult to organize an election committee. The costs of an election, and the time and effort to organize an election committee were enormous. It was to be avoided at all costs wherever possible. The electoral patrons in two member constituencies frequently split the two seats between the two political parties. "A spirit of political compromise existed in larger number of two member constituencies, where the Representation was divided between men of differing political principles."16

British aristocratic women's role of electioneer had two major components-electoral patron and election campaigner. First, women were electoral patrons, controlling the selection, nomination, and, if necessary, the election of a Member of Parliament for certain constituencies. Second, British aristocratic women campaigned in individual elections by canvassing, transporting voters to the polls, writing political material, directing campaigns, etc. The most notable example of an election with British aristocratic women direct participating was the 1784 Westminster election. Georgiana, her sister Lady Bessborough, and other Whig 
aristocratic women campaigned for Charles James Fox against the Tory women Lady Salisbury and Lady Hobart, supporters of Wray. The large number of British aristocratic women deeply involved in the election, and the extreme degree of violent press coverage made this the most famous election until modern times. However, British aristocratic women participated in elections both before and after 1784 .

\section{SOURCES}

British aristocratic women undoubtedly had their part in constituency electioneering, a part of which is easily traceable in reports of election committees in the journals of the House, in the municipal records, and in the letters and memoirs of the time. ${ }^{17}$ It is unfortunate that so few historians have included information on the role of women as electoral patrons. The information is there but not used. Only recently has historical research focused on electoral campaigns themselves and these unfortunately rarely mention the activities of women. The best sources of women's electoral influence are Porritt and the two histories of the House of Commons. But even these are woefully inadequate for this type of research. The indexes are poor. You need to read the entire text to find incidents of female activities and influence. 
We must be more careful on interpreting these sources. We must keep them in context and not place modern values upon them. For example, based on one letter from Georgiana to her mother, Lady Spencer, historians have stated that Georgiana despised her role in the election and that she was retiring to her mother's home because of all the grief Westminster has caused her. However, if you examine the subsequent letters you will find Georgiana was not discouraged, and she did not retire from campaigning. Lady spencer called her to st. Albans, the Spencer family home, not to rest from the vigors of Westminster, but to campaign for the spencer candidate. There Georgiana's popularity, gained at Westminster, was very useful. Historians also assume from this letter that Lady Spencer was not interested in politics and elections. Obviously this was far from the case. Lady Spencer was one of the most powerful electoral patrons, male or female, for decades controlling the nomination and running the elections in the Spencer boroughs.

\section{ELECTORAL PATRON}

An electoral patron was an individual who controlled the selection, nomination, and if necessary, the election of a member of parliament from an individual constituency. ${ }^{18}$ The patron-voter relationship implied mutual obligations not servile dependency. The relationship between patron and 
elector was a dual one, not onesided. The voters knew their price and were "most of all were fully aware of the favors, offices, patronage, and pleasures which could be their bargaining power as electors." ${ }^{19}$

Women were accepted as sources of parliamentary seats. ${ }^{20}$ Thomas Creevey lost his parliamentary seat due to the death of his patron. He asked the Countess of Darlington to get him a new seat. She told him she would take his interests "into her sacred keeping." ${ }^{21}$

\section{Motives}

The three prime, determining motives driving the electoral patronage activities of British aristocratic women were family, political party, and self. Of these family was the most important and the most enduring. The underlying purpose of electoral patronage activity was to maintain family interest, influence, and control in a constituency by placing male relatives in seats controlled by family interests. Von den Steinen called this the "unwritten but clearly understood code of electioneering conduct." ${ }^{22}$ Thus we can see British aristocratic women electoral patrons acting in the interests of their husbands, fathers, sons, brothers, and other male relatives. However, it is important to note that not all of the women electoral patrons were widows. Many, with husbands living, like Lady Salisbury and Lady Spencer, maintained their own electoral patronage power. 
British aristocratic women frequently were electoral patrons in the interests of their minor sons. These include Sarah, Lady Monson, at Lincoln, the Duchess of Dorset at East Grinstead, the Duchess of Newcastle; the Duchess of Rutland, Lady Bute, and Lady Durham. When Lord Monson died in 1809, leaving an infant son, Lady Monson kept the interest alive in Lincoln. She solicited a Whig candidate in 1811, saying she would pay all the election expenses above 5,000 pounds. ${ }^{23}$ When Lady Monson did marry a Tory, Lord Warwick, the Whigs were afraid her power in Lincoln would switch to the Tory party. However, she maintained the Whig interest. After the death of the fourth Duke, Maria, Duchess of Rutland, managed the family interest in Scarborough. ${ }^{24}$ In 1848 , the second Marquis of Bute died suddenly leaving a six month old male heir. From that time until her death in 1859, Lady Bute was the patron of the family boroughs. ${ }^{25}$ She lost the election in Cardiff lamenting the "ascendancy of revolutionary principles and the abasement of the family." ${ }^{26}$ Lady Durham was the patron of the Lambton interest in North Durham during her son's minority. ${ }^{27}$

British aristocratic women were also electoral patrons for the interest of their adult sons. It was Katherine Lowther who directed her son's political efforts, for the family interests in Cumberland and Westmoreland. She negotiated a pact with the Earl of Thannet to split the two 
seats at Appleby. ${ }^{28}$ Lady Beaumont, although a Tory, formed a successful coalition with the liberal, almost Radical Liddell against the Tory candidates of Howick/Grey and Bell. Liddell had "solicited and secured the backing of Mrs. Beaumont, with the implication the co-operation now might subsequently promote her son's election." 29

Political party affiliation was a secondary motive for British aristocratic women's activities as electoral patrons. This was especially true when the women patrons had no male heir. Mary Verney, heir to the Verney estates, placed the Verney interests at the power of the Prime Minister and the King in the late 1780s. She was created Baroness Fermanaugh in her own right because the Prime Minister "looking about for support in his difficult task of serving both the king and the Nation, was struck with the solitary figure possessed of so much political influence." ${ }^{30}$

Perhaps the most interesting motive inspiring the electoral patronage activities of British aristocratic women was self-interest. It was not common, but we can see examples in the literature of women patrons working, not for family interests or for their political party, but to please themselves. ${ }^{31}$ The Duchess of Dorset owned 29 out of 36 burgages in the borough of East Grinstead; and she returned both members. The Duke left the electoral patronage to her, along with all the money about 13,000 pounds per year. "So 
great an accumulation of wealth and parliamentary influence had scarcely ever been vested in a female." ${ }^{32}$ She used them to suit her own political interests. At times she placed them with her party and at times for relatives. It was not always easy as she withstood at least two election petitions to maintain her interests. ${ }^{33}$ In 1805, Lady Downshire, a widow, travelled to Ireland to defeat Lord Castlereagh in his election in County Down. ${ }^{34}$

Some British aristocratic women refused to surrender their power of electoral patronage when the son reached maturity. Lady orford held the family interests in Callington and Ashburton until her death in 1781. This was in spite of her son who wanted to run his own candidate. ${ }^{35}$ Some British aristocratic women forced their sons to fill the seat in order to maintain their control of the borough. In Boroughbridge, Mrs. Wilkinson owned more burgages than her rival, the Duke of Newcastle. However, Newcastle attempted to gain control of the borough. Mrs. Wilkinson insisted that her son, Marmaduke Larson, stand for reelection to prevent this. ${ }^{36}$ The son of Elizabeth Yorke, the Countess of Hardwicke, did not want to run for the parliamentary seat of the University of Cambridge, which was under the patronage of his mother. She committed him while he was out of the country on a visit. ${ }^{37}$ Anne Bouverie was the co-heiress of the electoral patronage of her father, Anthony Duncombe, Lord 
Feversham at Downton. In his will his burgages were split between Anne and a distant male cousin with the injunction that if she sold her burgages, the cousin would get first right of purchase. Anne challenged this injunction in the Court of Chancery and won. She was able to maintain her own interests in the borough. ${ }^{38}$

Not always did the son appreciate the electoral patronage of his mother. Mrs. Jane Osbaldston, widow of the MP for Scarborough, dragooned her son into the race for East Retford. She continued to manage the interest once he was elected. George her son said,

I stood much against my inclination and was returned. I thought it was a bore. I was so entirely engrossed with hunting, shooting, and athletic feats that I could not turn my thoughts to politics. It was only in response to my mother's entreaties that I attended the House on urgent occasions.

\section{Methods or the Delicate and Expensive Business}

While powerful, the power of electoral patrons was not absolute. Patrons controlled their constituencies through many methods, all of which involved vast amounts of work, money, and organization. It was a "delicate and expensive business." 40 Women electoral patrons created, bought and sold franchises. As landlords they threatened to evict and actually evicted tenants. They also provided loyal tenants with low rent. Women also traded and did business with shopkeepers and tradespeople in order to gain their support. 
They also gave money directly to candidates, provided charity to the destitute, and entertained electors in and out of the election season. All of the above came at great cost in money, time, effort, and many other forms of "insensible perspiration. " 41

The first method British aristocratic women used to control electoral influence was to control the franchise by creating, selling, and buying votes. Frequently patrons simply created new franchises, by erecting new burgages, or buildings with a franchise tied to them. This was true both before and after the Reform Bill of 1832. The 1832 Reform Bill made the manufacturing of votes easy by establishing standard property qualifications. Landowners could erect as many of the burgages as could possibly be contained within the boundaries of the borough. On the county level, landowners had the power to manufacture county franchises by letting property on life leases, thereby creating, what were in law, if not reality, 40 shilling freeholders. In Cardiff during the 1820s, Maria, Lady Bute, was especially effective in this method. ${ }^{42}$

Women patrons maintained and increased their control over constituencies by buying and selling seats. ${ }^{43}$ Boroughmongering, or the buying and selling of boroughs, was common throughout this century, even after the 1832 Reform Bill. Oftentimes women played a "sordid part in politics for 
women were frequently the channels between bribers and the bribed." ${ }^{44}$ Katherine Lowther bought more than 21 burgages for her interest in the burgage borough of Appleby in 1752 . They cost almost 8,000 pounds. ${ }^{45}$ Anne Lister, the Yorkshire landowner, also bought votes in order to support her interest. She eventually controlled over fifty votes. ${ }^{46}$ Miss Verney in 1787 sold her interest in the borough of Westover to Mr. Whitbread for about 2,000 pounds. ${ }^{4}$ In 1768 Pierce A'Court Ashe controlled the borough of Heytesbury, a burgage borough. His wife persuaded him to alter his will and to leave the burgages to her, instead of to his nephew. After he died, she sold the burgages for a goodly sum to the Duke of Marlborough. ${ }^{48}$

Women maintained their interest by buying up the houses and shops of those supporters of their rivals and then lowering rent to make the tenants more grateful or dependent upon them and more likely to do their bidding. ${ }^{49}$

Eviction and the threat of eviction were other powerful techniques in the maintenance of electoral control over constituencies. Even after the Reform Bill of 1832, "large numbers of the electors, being tenants, had to vote according to the landlord's wishes or find themselves harassed if not evicted." 50 Anne Lister frequently visited her tenants to urge them to support her candidate and she made no secret of the fact that she expected them to as she wished them to. ${ }^{51}$ 
Landlords were powerful. In 1832 a spirited landlady at Hertford, who had the election colors of her late husband torn down by a gang of election Bullies, retaliated by giving her tenant notice to quit unless he voted against the offending party. ${ }^{52}$ But usually no coercion was needed: tenants usually voted with their landlord anyway. Landlords were also expected to provide low rents and good maintenance and votes could be had by promising them. ${ }^{53}$ Charlotte, Lady Townshend, financed her candidate in the borough of Great Bedwyn. ${ }^{54}$ Anne Lister frequently gave large amounts of money to her candidates. ${ }^{55}$

Patrons also could grant or withhold their business or trade with shopkeepers and tradesman. Examples of women "pressing tradesmen" are "far from rare." ${ }^{56}$ There will be more of this in the next section on specific elections. Female patrons, did as a whole, in and out of election season control voters through trade.

Patrons also used charity donations as a means of coercing tenants. Mrs. Jane Osbaldston donated money and distributed coal and food to poor widows, the aged, and the needy relatives of voters. ${ }^{57}$ Maria, Lady Bute, made a crippled girl her protegee in 1825, so that she could get the vote of the girl's family. ${ }^{58}$ Mrs. Wyndham Lewis, wife of the current Member, 
has been ordering a great many blankets for distribution to the poor and particularly to poor freeman's wives. I therefore beg you will give blankets and coals in the inclement season.

British aristocratic women frequently entertained voters and their families, both in and out of election season. Women patrons threw open their houses for their voters. Though not all women were happy about the situation. The Countess of Cork wrote sadly,

Our doors are open to every dirty fellow in the country that is worth forty shillings a year. All my best floors are spoiled by the hobnails of farmers stamping about them. Every room is a pigsty and the Chinese paper in the drawing room stinks so abominably of punch and tobacco that it would strike you down to come into it. 60

British aristocratic women talked, dined, and danced with voters. The power of Lady Berkeley over her borough stemmed from the hunts, concerts, and balls not railroads, brewing, coal, or business interests. She "fully identified with all the town's social pursuits and that fashionable town life literally revolved around her." ${ }^{61}$ Lady Granville wrote to her sister Lady Morpeth,

I have been at the stafford races, betting and courting all the people at a very great rate. [There she met] Lord Bradford's steward, a man who says 'God damm you, how is Granville today?' It is difficult to meet this sort of fire and spirit in conversation with any degree of success. ${ }^{6}$

Lady spencer chided her daughter, Georgiana, for dancing with Mr. Wyndham, a personal friend, rather than spencer voters "Why did not you rather dance with some of the Gentlemen of the Country than with Mr. Wyndham." ${ }^{63}$ In 1794, Harriet, Lady 
Bessborough, to appease the spencer interests at st. Albans attended a morning reception of aldermen and their wives "cramming them with hot rolls and butter (at eleven in the morning) while John and Fred [Harriet's sons] danced with the Misses. " 64

\section{INDIVIDUAL WOMEN ELECTORAL PATRONS}

There were many prominent women electoral patrons, many of whom have been mentioned above. However, there were three prominent electoral patrons whose patronage activities reveal much of the influence and power held, and thus merit a closer study. These women were Lady Spencer, Lady Irwin, and Miss Lawrence. ${ }^{65}$

Lady spencer, mother of Georgiana, was a powerful electoral patron in the spencer interests. Her political power has been overlooked for two reasons. First, her daughters, Georgiana and Lady Bessborough, were so much more politically active and in their limelight they overshadowed Lady spencer's more quiet and enduring power. Also, as mentioned in the introduction for this chapter, historians have, as a group, determined that Lady spencer was not interested in politics and hated electoral work of all kinds, and thus was not politically active. Perhaps Lady Spencer 
did hate politics, but this feeling was irrelevant. Lady Spencer was a very powerful electoral patron. While her husband was alive he depended upon her to direct the interests of the family, because as a peer he could not.

Through her letters we can see she was active as an electoral patron in many spencer boroughs, both as a married woman and as a widow. In 1784 alone, she managed the nomination in two boroughs--St. Albans and Northampton. ${ }^{66}$ She was the patron of St. Albans all her married life. During the 1784 election in St. Albans, Lady Spencer described to her son one method she used to secure the Spencer interest in the borough.

Lady Salisbury has canvassed the town we were told with amazing success, and she threw a sort of spirits upon their party that depresses ours. So last night I sent for your two sisters [Georgians and Harriet, Lady Bessborough] who set out an hour ago with Mr. Sloper [the Spencer candidate], and a very large body of friends to make a regular canvass. It is amazing what this has already done.

It is hard to understand how the historians, especially the editors of her letters could reach the conclusion that Lady spencer did not like politics. Yes, she was fond of pronouncing that she did hate politics and elections but these were rare instances. She told lady Bessborough she should not write to her until the "vile election" (1784 Westminster Election) was over. ${ }^{68}$ "I could care less about politics than most people," Lady spencer to Lady 
Bessborough. ${ }^{69}$ "As to your elections, I abominate the'" she said in 1812 to Lady Bessborough. However, she continued on in the letter to say she was "rather anxious nevertheless to know how many of you are ruined by them [the elections]." 70 Indeed many historians have accepted her based on these few words as the true reflection on her political activity. They have ignored the more numerous letters in their own collection that firmly and strongly illustrate that Lady Spencer was thoroughly involved in politics of the time period. She was constantly soliciting information from her daughters. She nagged at Lady Bessborough,

that all you write is second hand news, that I must be better informed. It was mortifying [not to get political information] because when the post came in, the whole circle seated at breakfast talked impatiently of what news I should have.

She talks frequently about elections all over England.

There is more ill humor here than I expected, my dear Harriet, but nothing I trust that will endanger the election. There is much violence between Grimstone and Halsey so as to come to personal altercation but of this we are perfectly clear. Dear Duncannon has gone through a most tedious and fatiguing canvass this broiling day. . " 72

In reality she was what Namier called he in his history of the House of Commons--"a formidable electioneer." ${ }^{73}$

Lady Irwin was the electoral patrol for the Ingram family interests in the burgage borough of Horsham for 29 year. ${ }^{74}$ The Ingram family, the Viscounts Irwin, acquired the interest in the borough in the early eighteenth century. 
Lady Irwin's control over the borough was secure until 1787 when the new Duke of Norfolk decided that he, as Lord of the Manor, wanted control over the borough. ${ }^{75}$ Lady Irwin fought for decades against Norfolk, having many memorable contests. This was one burgage borough that was contested frequently. The most notable contests were in 1806 which she lost, and in 1807, which she won. She was in "electioneering craftiness and determination a match for the Duke." 76

At the General Election of 1806, after fighting the Duke of Norfolk for 16 years, at the age of 74, she still did not want to give up control of the borough.

She still looked upon the Borough as her own, and the proceeds from the sale of the seats as her proper perquisites. She won this election, but died shortly afterwards. Ironically, Norfolk bought out her interests after her death from her heirs. But it cost him dearly, over 91,000 pounds. ${ }^{77}$

Lady Irwin also frequently sold her seats. Until the struggle began with the Duke of Norfolk, she controlled enough votes to guarantee that any candidate sponsored by her would be elected without a contest. In 1806 she sold her seats to Palmerston and Fitzharris for 4,000 each pounds. ${ }^{78}$

Part of Lady Irwin's success in her borough was due to her continual "treating" or wooing of the voters. Lady Irwin "did her faggot-voters the honor of pretending to canvass their support for her candidates, neither of whom was as yet 
named." She gave them a venison feasts from 1788 on, even after her election defeats. ${ }^{79}$

Elizabeth Lawrence was the electoral patron of the burgage borough of Ripon in Yorkshire. She controlled 100 of the 146 burgage voters. From 1781 to 1807 she shared the responsibility with her sister, but from 1807 to 1845 she was the sole patron. ${ }^{80}$ Miss Lawrence was one of the wealthiest women of her time and her electoral influence at Ripon was strong. The 1832 Reform Bill did not diminish her influence in the least. Before 1832 there were about 146 burgage tenants, after 1832 about 350. She also added new buildings to qualify for franchise. In April 1834 her political rivals brought a petition to the House of Commons to protest these faggot votes. "The cow-houses and other mean buildings whereby the borough was being virtually swamped by the discretely unnamed proprietress of much property in the neighborhood." Joshua Crompton, the Whig member, told the House that "If the lady in question continued with her plans, it soon would be a mockery to call Ripon an open borough, it soon would be emphatically her borough." The petition was tabled. ${ }^{81}$

The 1832 Reform Bill made the manufacturing of votes easy by establishing standard property qualifications. Landowners could erect as many of the burgages as could possibly be contained within the boundaries of the borough. 
The next two elections after 1835 were not contested. ${ }^{82}$ Miss Lawrence used her borough for party not family. A 1844 political pamphlet, for example, accused her of placing both seats at the disposal of the Tories.

For many years in the hands of the late Miss Lawrence, one of the wealthiest heiresses in the north of England, who always placed it at the disposal of the late Sir Robert Peel. Now by request from Miss Lawrence, vested in Earl Grey.

As mentioned earlier, at the first election after 1832 , Miss Lawrence's two candidates lost in a close election (less than 10 votes). However, she soon regained her electoral control over the borough through threats of eviction. All her tenants were given notice to quit after the election defeat in 1832. But only the nine who really did vote against her were forced to move out. But she made her point. The next election in 1835, all her tenants voted for her Tory candidates. ${ }^{84}$

\section{ELECTION CAMPAIGNER}

An election in the mid-eighteenth to mid-nineteenth century usually consisted of four steps--preliminary canvass, general canvass, nomination, and a poll (or the official vote). ${ }^{85}$ Due to the enormous expense involved in each step, elections rarely reached the stage of a poll, stopping at an intermediary step, usually the preliminary canvass. ${ }^{86}$ But having elections so expensive made the contributions of 
British aristocratic women more valuable and gave them more opportunities to exert political power. British aristocratic women participated in, and even directed, each of these election steps.

British aristocratic women were active canvassers. They canvassed, or solicited votes, in person and via letter. Canvassing was an expected electioneering function for women, one upon which the political system depended, especially in the light that peers could not canvass. Women wore a new style of hat, called the canvassing cap, which they decorated with the ribbons of their favorite candidate. ${ }^{87}$ In Nottingham in 1820, the candidate proposed a toast to "Our female friends to whom we were so much indebted on our canvass in Nottingham." And in 1820 in Boston, a candidate toasted "For my Female Advocates, so good, so fair, so strenuous, so decided." The Fitzwilliam family ladies "naturally took an enthusiastic share in the election." Lady Milton, his mother, canvassed her London merchants and Lady Bessborough, his aunt, canvassed the Prince of Wales. ${ }^{88}$

Women were very effective canvassers and they were effective because of their sex. Lady Susan Bunbury in 1767 successfully canvassed 94 out of 100 voters at Morpeth. To which feat an observer wondered "how those remaining six could withstand so charming a solicitress." ${ }^{89}$ Women used their sexuality or charm through their "public flaunting of 
fairly innocent sexual and sartorial behavior. A kiss, a wave, and a dress of flamboyant colors were common features of the general canvass. "90

Female canvassers were not always acceptable to everyone. The early parliamentary historian, Grego, related the story of Sir Charles Turner (MP from York 1768-1783) who attacked a female canvasser with a whip. Turner flourished his whip and

forcibly demonstrated his aversion to rival canvassers of the gentle sex, much to the consternation of the ecclesiastical hierarchy and gownsmen, while the rough townsmen are cheering their $\frac{r}{91}$ eccentric candidate and promising to support him.

The Morning Post believed that women kissing for votes "ought to be considered as undue influence. "92

As to be expected in a political system that depended so strongly on social ties, British aristocratic women canvassed for family members. Lady Salisbury in 1812 canvassed so successfully for her son, Lord Cranborne, that the opposition candidate, sir John Sebright, also felt obliged to canvass. ${ }^{93}$ Mrs. Thrale campaigning for her husband in Southwark, said "We succeeded pretty well upon the whole. I showed my consequence and frightened my antagonists." 94 Lady Howick was "pressed into service" during an election in 1841 by-election in Sunderland. A member of Howick's election committee forwarded a list of 
nine voters "with whom Lady Howick might possibly have some influence." 95 Lady strathmore canvassed for her husband in Newcastle in 1777 and Lady Minto in 1806. ${ }^{96}$

However, what was surprising was the frequency that British aristocratic women canvassed for non-family candidates-for friends, or for political party, or for their family's traditional interests. (It was traditional that family controlled the seat, even if no relative was a candidate.) Through their canvassing for friends and political party favorites, we can see another aspect of how valuable women were to the election process and how dependent the political structure was upon them. Interestingly enough, most of the examples in the literature concern women campaigning for non-family members. Lady spencer herself participated in elections for non-family members, though still in the family interest. In 1774, Lady spencer campaigned in Northampton, a spencer borough. She set out on a Thursday morning with Mrs. Tollemache [wife of the spencer candidate] in my cabriolet and four, in hopes of putting as little spirit into our people who were sadly discomposed at having neither money or drink offered to them. I succeeded much beyond my expectations, for I no sooner got to the George than a little mob surrounded us and instead on taking off our horses and drawing us round the town. In a very few minutes we had a mob of several hundred people, screaming spencer forever. I went through the same ceremony on Friday. It has had an extraordinary good effect in the election, for it has ensured Mr. Tollemache a great majority. 
In 1788, four years after the famous Westminster election, there was another election at Westminster. Georgiana solicited votes by mail in the mornings and met with party leaders at Devonshire House in the evenings to "sup and settle matters." 98 In 1799, Lady Lawley and other women Canvassed for Granville Leveson Gower in Staffordshire. ${ }^{99}$ Mrs. Arbuthnot canvassed for her friend Mr. Bankes in 1822. ${ }^{100}$ Charles Greville, the diarist, stated "Lady Glengall's dragging everybody down and canvassing with unparalleled activity and effrontery", also in the 1822 election. 101

Women played an important role in the preliminary rounds of the preliminary canvass. In his diary, Lord Ellenborough "wrote to Dr. Broderick asking him what chance a candidate of the conservative party would have at Dover. I begged Anne to write to Mrs. Firebrace to ask the same thing. "102

Beyond canvassing, British aristocratic women orchestrated and participated in other parts of the election campaign. They took voters to the polls. Free transport to the polls was expected by voters. Frequently there was only one polling place for the entire constituency. During the 1819 Westminster election, Lady Caroline Lamb transported "all the greasy voters in her carriage to the hustings."103 
Women also appeared on the hustings, or platforms erected at the polling places. Esther, the second wife of Sheridan, appeared on the hustings on the behalf of Sir Francis Burdett in 1802. ${ }^{104}$ Caroline Lamb appeared besides her brother-in-law, George Lamb in 1819. ${ }^{105}$ Lady George Cavendish appeared on the hustings for her son, Charles Compton in 1820. ${ }^{106}$ Lady Cowper appeared next to her husband, Lord Palmerston, at Tiverton in 1841. ${ }^{107}$ However, with the Duchess of Northampton, as mentioned earlier in this chapter, appearing on the hustings was a late development in the arsenal of electioneering methods for women. Also women only appeared for family members. No woman appeared on the hustings in the famous election in Westminster in 1784 .

British aristocratic women participated in the chairing of candidates. Chairing was the daily procession of the candidate to the hustings and included the final victory parade. $^{108}$ When no official chairing took place, often the populace created a mock chairing. In 1822 Kings Lynn people demanded a chairing. The candidate sir William Folkes was unavailable.

A potty-looking and rather ancient dame bedecked in Folkes colors was seized and chaired [in his place]. She soon reconciled herself to the excitement of the occasion and assumed a regal air and delighted the onlookers.

Lady Palmerston, the mother of the Prime Minister and a Tory, wrote in 1790 "Sheridan has a violent contest to contend with 
at Stafford. However, he has the ladies at his side - for he was attended into the town by four hundred, headed by a beautiful Miss Furnio." 110

British aristocratic women also performed other valuable functions during an election campaign. They traded only with those shopkeepers who supported their candidate. They frequently bought goods at inflated prices to insure good will and get votes. They paid "5 guineas for a bundle of broccoli, 8 guineas for a leg of mutton, etc."111 They out right bribed voters. However, bribing, or treating, was considered by contemporaries to be a natural part of electoral patronage. Treating did not necessarily impede freedom of choice in elections. It may well have been an effective means of rewarding loyal support and mobilizing and reinforcing favorable opinion, rather than a means of altering election results by subverting the electorate. ${ }^{112}$

The most famous example of women bribing voters occurred in 1776 Newcastle election with Lady Strathmore. A political rival described how

her ladyship sits all day in the window at a public house, from whence she sometimes lets fall some jewels or trinkets which the voters pick up, and then she gives them money for restoring them to her--a new kind of offering bribes.

Lady Salisbury was famous for driving through the streets of the county and throwing money out to the populace. ${ }^{114}$ At the 
Queen's Head, Margaret Burton heard William Wellesley Pole (Wellington's older brother) say

Good God, we shall loose the election. We'll give to the amount of 50 to 100 pounds to as many as will do so! Margaret told him she could get him a voter for less than that, but found she could not do so as two men were guarding his door to ensure his neutrality.

Lady Salisbury also developed a "Foxhunting Club" for the supporters of her son, Lord Cranborne in 1812. ${ }^{116}$

British aristocratic women also wrote campaign material. Mrs. Coke wrote a canvassing letter for her husband in 1784. "An intention is publicly avowed by Sir J. Wodehouse's friends to disturb the peace of the county by putting him in opposition to the old members." ${ }^{117}$ Mary Robinson, a rabid Foxite, supported Foxite candidates in the 1784 election in Liverpool by writing "squibs, paragraphs, and songs" for the campaign. Lord Cornwallis wrote Colonel Ross and said "Fox, however, is 288 behind sir Cecil Wray, not withstanding the efforts of the Duchess, Mrs. Bouverie, and Mrs. Robinson." ${ }^{118}$ She also wrote campaign songs for a campaign in 1790 at Liverpool. ${ }^{119}$

British aristocratic women entertained voters and their families during election time. In 1774 Georgiana gave a ball in Derby, where she "danced Country dances with Mr. Coke (the candidate's son) but as nobody was refused at the door the ballroom was quite full of the daughters and wives of all the 
voters in checked aprons."120 Harriet, Lady Bessborough, campaigned for the spencer candidate in st. Albans. She described her electioneering activities to her lover, Lord Granville.

My brother sent me to beg I would come here to do civilities for him. But more to attend a morning ball and visit some freeholders' wives whom he wanted to please. Conceive of being dressed out as fine as I could at eleven o'clock in this morning, squeezed into a hot assembly room at the Angel Inn, cramming fifty old aldermen and their wives with hot rolls and butter, while John and Fred [her sons] danced with the Misses, playing at fourpenny, commerce, and the tradille, and then visit all about the gay town of St. Albans. Can you beat anything to surpass this? ${ }^{121}$

\section{INDIVIDUAL WOMEN ELECTIONEERS}

Three women stood out as prominent and unique campaigners. They were the Duchess of Northumberland, Jane Osbaldston, and Lady Caroline Lamb. The Duchess of Northumberland campaigned regularly for her son, Lord Percy. In 1767, the contest was Percy against Wilkes. Horace Walpole said wilkes was winning the election until wilkes "met with a heroine to stem the tide of his conquests, who, although not an Arc nor a Purcell ia a true Joan in spirit, style and manner. This is her Grace of N., who has carried the seat of Westminster from him." She sat daily at the hustings in Covent Garden. ${ }^{122}$ However, in the 1774 campaign, her behavior began to upset contemporary sensibilities. She 
even disgusted Walpole. ${ }^{123}$ Mrs. Delany said the Duchess's performance during the campaign were "extraordinary [considering] that the Duchess was of the bluest blood, having seven baronies in her own right." ${ }^{124}$ Besides her daily canvassing, she again appeared on the hustings daily "haranguing the populace" to vote for her son. ${ }^{125}$

The 1807 Yorkshire election was the most famous election during this time, next to the 1784 Westminster Election. It certainly was the most expensive. Jane Osbaldston, the "formidable electioneer" from Yorkshire was in the center of the contest in Yorkshire. ${ }^{126}$ Her son said she "actually canvassed in person every voter within 20 or 25 miles of Hutton Bushell, and it was universally acknowledged that to her extraordinary exertions his [Milton's] victory was due."127 Smith considered this an impressive achievement since the Pickering Lythe Wapentake was a Lascelles stronghold. ${ }^{128}$ Milton and his supporters also rewarded her extraordinary efforts. After the election she had a triumphant reception at Malton, where she was

drawn by the populace round the town, preceded by an excellent band of music, with gold fringed colors waving before them, amidst the ringing of bells and a thousand acclamations from the victorious party.

When the election resulted in a petition to the House of Commons, Jane also successfully obtained information that 
threw the petition out of court. ${ }^{130}$ Jane also canvassed in the Malton elections of 1807 and $1808 .^{131}$ Her son, the squire Osbaldston, criticized his mother by saying her ruling passions were "notoriety and gaiety."132

Caroline Lamb was famous for her "wild canvassing" for George Lamb's (her brother-in-law) contest at westminster in 1819. ${ }^{133}$ Princess Lieven believed that Caroline won the election.

It is well-known that last year (1819) she was worth more than a thousand votes to her brotherin-law. There are no two opinions about the price at which the majority of these votes were bought. She made no bones about going into the taverns and dancing and drinking with the electors. What else she did is surrounded in obscurity. Anyway she put such energy into her canvassing that, in the end, her brother-in-law defeated Hobhouse himself. Burdett, the later's patron, admits that it was she who deserved all the credit for Lamb's election. ${ }^{134}$

David Cecil, Lord Melbourne's biographer, described her actions in a different light, one to show less kindly upon this crazy wife of his subject.

At once she drove up to London and invaded the local taverns where she diced and drank with the voters in order to win them to the good cause. One day, driving through the streets in her carriage, she was assaulted with a volley of stones by a mob of angry opponents. Here was an opportunity indeed for a heroine to display her quality. Stepping out with head held high, "I am not afraid of you," cried Caroline magnificently, "I know you will not hurt a woman--for you are an Englishman." 135

Her electoral activities were accepted during the contest in 1819. But her activities during the next election drew harsh 
criticism. Princess Lieven this time believed the Radicals owed their victory to that "madwoman." 136

British aristocratic women campaigned in many elections throughout the mid-eighteenth to mid-nineteenth century, for as variety of reasons, and utilized many methods of campaigning. As Princess Lieven herself said in 1820 "People have no idea to what an extent women have influenced the elections in England." ${ }^{137}$ Women's electoral activities fit in with the carnival atmosphere of English elections, an atmosphere that was "rarely conductive to any rational disentanglement of the issues involved."138 Indeed of most parliamentary elections during this time "it might be said that they were about nothing and that they were won by nobody. " 139

There were no national political parties to argue national issues. Elections concerned local issues. "A hotly contested election was a long orgy of noise, drunkenness, corruption, bullying, general rudeness, lying, bribery, fraud and violence."140 Elections were incredibly violent. Indeed it was part of the success of Georgiana and the others at Westminster in 1784, was due to their bravery at facing the violent mobs. Canvassing, transporting voters to the polls, chairing, all involved facing the violent crowds. The threat of violence added interest and excitement for women. In her journal, Fanny Burney discussed the Westminster election of 
1788 where Lord John Townshend beat Lord Hood. Colonel Manners said it was a rough, violent campaign.

I asked him whether his electioneering with so much activity did not make his mother a little uneasy? "Oh, it does her a great deal of good" cried he, "for I could never get her to meddle before. But now when I had my head broke, it provoked her so. She went about herself canvassing among the good people, and she got us twenty votes.

\section{WESTMINSTER ELECTION}

The 1784 Westminster Election was the most famous election in British history. It made charles Fox and Georgiana, Duchess of Devonshire famous throughout the entire country. Elections "usually resembled an organized riot, but this critical contest took the shape of a veritable Saturnalia."142 It was a combination of a prizefight and masquerade. All trade stopped in the area and daily there were mobs, riots, processions, music, and speeches. During the forty days of the election polls the entire western section of the city, centered in Covent Garden, "presented a scene of uproar and disorder which is difficult to describe."143 Westminster was a borough with an extremely large voting populace. It stemmed from its unique franchise. Each male inhabitant householder had the vote, not just the typical property requirement, as in other boroughs. This 
resulted in a large number of potential voters, and thus a large amount of public interest also.

What made this election so famous was the amount of press coverage generated much of which centered on the electoral activities of the women involved. Tons of pamphlets, cartoons, lampoons, and poems flooded London and the rest of the country Horace Walpole estimated that it would cost about six or seven pounds to purchase one copy of all the satiric prints alone. And this was still two weeks until the closing of the polls. ${ }^{144}$ For example, of the 62 satiric prints published between 29 March and 29 April, over one half commented on Georgiana. ${ }^{145}$ However it is important to note that the reason the Press was so violent against Georgiana was because she was so successful, not because she, a women, was campaigning. The press coverage was a tribute to her effectiveness.

The motives and methods British aristocratic women's electioneering activities in Westminster show how and why British aristocratic women were so valuable and uniquely effective. The odds were stacked heavily against Fox. It was Georgiana and the other Whig women who made, at least in Westminster, the odds more even for the Whigs. The Fox-North Coalition was badly outmatched against the combined powers of the King, Pitt, and the East India Company. 
Westminster, however, was the most strongly contested constituency. It pitted the Foxite Whig leader Charles James Fox against the ministerialist Tory, Sir Cecil Wray, himself a former Foxite. Westminster returned two members. Lord Hood, a popular and heroic admiral, was assured of one of the two votes. Fox and Wray fought for the second seat. There was an initial canvass of about forty days, leading up to the opening of the polls on 1 April 1784. Another forty days later on 17 May, the polls closed and Fox won the second seat. One may argue that even though this election repopularized Fox, it did it at a very high price. The 1784 General Election resulted in enormous defeat for the whigs. They lost over 160 members, whom in typical Whig fashion, were promptly dubbed "Fox's Martyrs." In spite of this overall Whig failure in the General Election, Westminster proved to be the bright spot, the one great success. Much attention was paid to it because so much rode on it.

The victory in Westminster was the result of the electioneering activities of aristocratic women. It was a "Iadies battle." ${ }^{146}$ Without the efforts of British aristocratic women, Fox would not have won the election. "A bevy of fine ladies cast decorum to the winds and plunged into the fray. 'A kiss, a vote, and the devil take the hindmost' were their mottoes." ${ }^{147}$ During the campaign, women 
canvassed voters and transported voters to the polls. Women even kissed voters to obtain votes. They rabidly discussed the election at almost every social function, at times getting into heated arguments. They wore their party's colors and symbols on their clothes and carriages. Women also threatened shopkeepers with loss of their trade unless he voted for their candidate. ${ }^{148}$ Women participated in many election parades.

Was this level of electioneering unusual for women? Yes and no. It was unusual for three reasons. First, a large number of British aristocratic women campaigned on both sides. Second, while the activities themselves were not unusual female activities, the large amount of them were. Women had canvassed and transported voters to the polls, and even kissed voters to obtain votes before 1784. They would campaign in other elections afterwards. Third, as mentioned earlier, this election was also unique because women were so active for non-family members.

Georgiana was the most glorified (as Fox's Duchess) and also the vilified woman involved un the election. Her primary motive was to support the cause of Foxite Whiggism. Georgiana's most important role in the election was acting as a unifying force for the Foxite Whigs. While the Tories were victorious elsewhere in the country, she kept the Whig hopes alive. She also revitalized Fox, keeping him as a viable 
head of the whig party. It was she who was the star of the campaign. In addition as the Foxite Whig cause was so close to the cause of the Spencer-Cavendish, she was also supporting her family interests. ${ }^{149}$ Second, Georgiana must have found her activities stimulating and exciting. She wielded great power. She was only 26 years old and was at the center of a very important, and popular, election. ${ }^{150}$

Georgiana's electioneering activities at Westminster did not differ in type from women's activities in other elections. They differed only in scope. Georgiana canvassed, transported voters, to the polls, threatened shopkeepers, and entertained.

Georgiana's most noted role in the election was that of indefatigable canvasser. ${ }^{151}$ In one of the most famous quips from the election she (and her sister, Lady Bessborough) were called "the most perfect pieces that ever appeared on a canvass"

Sure Heaven approves of Fox's cause, (tho' slaves at court abhor him), To vote for Fox, then, who can pause' Since angels canvass for him.

Georgiana's canvassing was so effective that the Tories sent out their own female canvassers, to the scorn of pundits.

Get out, you female Tory

Though Courts prevail, I'll not turn tail

The Duchess was here before ye.

Westminster was divided into three districts. Georgiana, Mrs. Crewe, and Mrs. Damer were in charge of one. 
With polling lists in hand, they scoured for voters, first in the central area, then in the suburbs. ${ }^{154}$ This was the most extensive canvass in any election. Lord Fife told the story of returning home to London and finding Georgiana canvassing his pastry cook. ${ }^{155}$

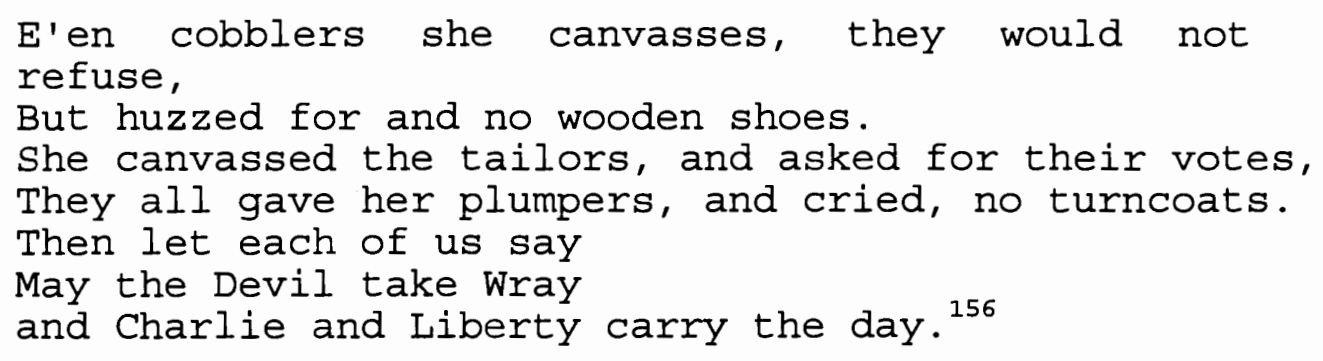

Georgiana was also famous for transporting voters to the hustings, in her regal carriage, bedecked with Fox colors. Many voters were reluctant to go to the polls in the riotous Covent Garden, due to the violence associated with the area. Riding in a fancy ducal carriage, and sitting next to a beautiful and famous duchess, overcame many fears. ${ }^{157}$ In addition to canvassing and transporting voters to the polls, Georgiana would also sit in her carriage outside Fox's campaign headquarters at the shakespeare tavern and greet voters. Sometimes she would sit inside in a tavern window and wave. ${ }^{158}$

Another method Georgiana utilized in the campaign was to coerce shopkeepers. She also used to go to shops and buy goods at greatly inflated prices. This would entice the tradesman into voting for Fox. This usually was highly 
successful. She ordered 50 pounds of hair powder from each of two hair dressers "at their own prices and requested them to vote for her Grace's candidate. Their alacrity to serve her Grace need not be doubted". ${ }^{159}$ Georgiana asked a tallow chandler in Oxford street to vote for Fox. He agreed if she would be his daughter's god-mother. Georgiana agreed and the child was given her name. ${ }^{160}$ Georgiana also had 1000 Coalition Medals made up and distributed to voters. ${ }^{161}$

Georgiana threw the weight of Devonshire House behind the campaign efforts. She held many dinners and breakfasts during the campaign, for voters and supporters. She also used her power to coerce other people into entertaining for Fox.

I have made $M$. Adhemar [the French ambassador to Britain] give me an opposition supper for Charles Fox, Grenville, the Duke of Portland, and all my

tribe. It went much against the grain with him. During the whole campaign, Adhemar simply could not believe his eyes. His reports back to France were now done on a daily, not weekly, basis. He especially commented on the activities of Georgiana. ${ }^{163}$

Devonshire House was also the site of daily campaign strategy meetings with Fox, the Duke of Portland, the Prince of Wales, and others. ${ }^{164}$ It was Fox's second home and it was the terminus of the victory parade. Villiers believed that it was Georgiana and her sister, Lady Bessborough, who 
"conceived the daring plan" for the campaign. ${ }^{165}$ She was the only historian to do so. Obviously Georgiana had some input into determining her electioneering activities, since so much depended upon her own effort and fortitude. But her exact role can not be determined from the available literature.

Georgiana was not the only active woman campaigner in the 1784 Westminster Election. Other British aristocratic women, from both political parties, participated. They performed the same functions as Georgiana, but on a smaller scale. They canvassed, transported voters to the polls, entertained, and proudly wore their party's emblems and colors. ${ }^{166}$ However, the whig women were more active in Westminster for two reasons. First, for the Whigs, this was an accepted role for women. Whigs were accustomed to depend upon their women for political structure and support. Second, Fox also desperately needed their assistance, whereas the Tory situation was not as grave.

Harriet, Lady Bessborough, campaigned frequently, and often more strenuously, with her sister, Georgiana. Georgiana described her sisters activities, "MY sister is gone to the opera quite well to sport her cockade [emblem for Fox]." ${ }^{167}$ She canvassed heavily and was also thought to exchange kisses for votes. Frances, Mrs. Crewe, also canvassed heavily and transported voters to the poll. Wraxall believed Mrs. Crewe "had exerted herself in securing 
Fox's election, if not as efficaciously, yet as enthusiastically as the Duchess of Devonshire." ${ }^{168}$ She hosted the victory ball where the Prince of Wales made his famous toast to her "True Blue and Mrs. Crewe." To which she replied "True Blue and All of You." Other Whig women active in the election included Mrs. Bouverie, Mrs. Damer, and the beautiful ladies Waldegrave.

Fair Devon all good English hearts must approve, And the Waldegraves (God bless their sweet faces), The Duchess she looks like the sweet Queen of love, And they like the three Sisters Graces.

About Lady Beauchamp, Lady Carlisle, and the Countess of Derby the whig songsters wrote

The Gentle Beauchamp, and the Fair Carlisle, Around their favored Fox, expected wait

At Derby's lip's suspends the ready smile,

To ask "The Poll?" and "What is Charlie's Fate?"170

Both Duchesses of Portland campaigned. According to the Morning Post, the old Dowager "has attacked with chit chat and voluble persuasion. The duchess, her daughter in law, with mildness and sensible moderation."171 Lady Salisbury was the most prominent Tory woman participating in the election. "In graces of person and demeanor, no less than in mental attainments, Lady salisbury yielded to few females. "172

A certain lady I won't name Must take an active part, sir To show that Devon's beauticious dame should not engage the heart, sir. 
However, Lady Salisbury's canvassing efforts failed. Part of her failure was due to her haughty demeanor that failed miserably in comparison to Georgiana's open charm. She was too conscious of her rank and was always "compelling others to recollect it. ${ }^{174}$

She canvasses all, both great and small,

And thundered at each door, sir.

She rummaged every shop and stall

The Duchess had been before her. ${ }^{175}$

Years later, when her husband was fired from a high government position, Lady Salisbury made it clear that the Tory party owed her for the abuse she underwent in 1784 . "Mr. Pitt must remember that I underwent a great deal of unworthy abuse by canvassing at his desire in Westminster." 176 Other Tory women campaigners included Mrs. Hobart and the Duchess of Rutland. Mrs. Hobart, Lady Buckinghamshire, was also an active canvasses for the Tory side. But the Whigs believed she was too overweight to compete with the beautiful whig women and called her Madame Blubber. The Duchess of Rutland also was and active Tory campaigner. Georgiana stated

I was at the opera. It was very full and I had several good political fights." The Duchess of Rutland said "D__ Fox," upon which Colonel st. Leger with great difficulty spirited up Lady Maria waldegrave to say "D__ Pitt." 


\section{CONCLUSION}

The examples show that British aristocratic women indeed wielded great political power through their dual electioneering roles of patron and campaigner. Up to now in this thesis we have seen British aristocratic women only politically active in London - as political hostesses, patronage granter, and political advisor. In this role of electioneer British aristocratic women were also active in London, notably as campaigners in the boroughs of Westminster and Southwark. But British aristocratic women also played an extremely important political role outside of London. They were patrons throughout much of England and Scotland, controlling the nominations of many members of Parliament. Women also campaigned in many elections throughout Britain during the time period covered by this thesis. The examples above demonstrate the political strength of British aristocratic women in this role as electioneer, ones upon which the political system of the time depended. The sociopolitical system, and the lack of a national party organization, demanded this role from women. As more historians study electioneering of this time it is important to recognize the dual role British aristocratic women played. As women's historians discover this time period, they should 
not overlook this role. It was not as glamorous as others but it was important for their contemporaries. 
ENDNOTES FOR CHAPTER V

${ }^{1}$ Commons Journals $\times 111$ p. 648 quoted in John Ashton Cannon, Aristocratic Century: The Peerage of the EighteenthCentury (Cambridge, England: Cambridge University Press, 1984), p. 104. The Commons passed a similar resolution in 1801, after the union with Ireland].

${ }^{2}$ Lewis, "Political Behavior", p. 252.

${ }^{3}$ Soulbury, "Women of Influence," p. 400. See also John A. Phillips, "Structure of Electoral Politics in Unreformed England," Journal of British Studies 19 (1979): 79 .

${ }^{4}$ Though not all patrons were peers. James J. Sack, "The House of Lords and Parliamentary Patronage in Great Britain, 1802-1832," Historical Journal 23 (1980):918.

${ }^{5}$ Aristocratic influence of the patrons did not immediately die in the counties and boroughs. Aristocratic control of at least small boroughs "survived at least until the late nineteenth century." John Davies, "Aristocratic Town-Makers and the Coal Metropolis: The Marquis of Bute and the Growth of Cardiff, 1776-1947," in Patricians, Power, and Politics in Nineteenth Century Towns, ed. David Cannadine (Leicester, England: Leicester University Press, 1982), p. 45; Richard Trainor, "Peers on and Industrial Frontier: The Earls of Dartmouth and of Dudley in the Black Country, $c$. 1810-1914," in Patricians, Power and Politics in Nineteenth-Century Towns, ed. David Cannadine (Leicester University Press/New York: St. Martin's Press, 1982), p. 85; Charles Seymour, Electoral Reform in England and Wales: The Development of the Parliamentary Franchise, 1832-1885, new intro. by Michael Hurst (New Haven, CT: Yale University Press, 1915; reprint ed., Hamden, CT: Archon Books, 1970), p. viii.

${ }^{6}$ Charles R. Dod, Charles R. Dod's Electoral Facts From 1832 to 1853 Impartially stated, ed. H. J. Hanham (Brighton, England: Harvester Press, 1972), p. xxiii.

${ }^{7}$ R. G. Thorne, House of Commons, 1790-1820, 5 vols. (London: Secker \& Warburg for the History of Parliament Trust, 1986), 1:4, 41-44. See also Norman Gash, Politics in the Age of Peel: A study in the Technique of Parliamentary Representation 1830-1850 (London: Longmans, Green, 1969), p. xvi.

${ }^{8}$ Dod, Charles R. Dod's, p. xxiii. 
Thorne, House of Commons, 1:17. The 45 titles included 7 Irish peers, 21 heirs to peers, and 17 lords, such as younger sons, or brothers of dukes or marquises.

${ }^{10}$ Thorne, House of Commons, $1: 44$.

${ }^{11}$ Porritt, Unreformed House, p. 40. Franchise in a corporation borough was held by a select group of men. In a scot and lot borough, if you paid the poor rate, called the scot and lot, you had the vote. There were 66 scot and lot, or inhabitant, boroughs].

${ }^{12}$ Edward Gillett, History of Grimsby (London: Oxford University Press for the University of Hull, 1970), p. 151; Porritt, Unreformed House, 1:78; Thorne, House of Commons, $1: 38$.

${ }^{13}$ John A. Phillips, Electoral Behavior in Unreformed England (Princeton, NJ: Princeton University Press, 1982), p. 62 .

${ }^{14}$ Porritt, Unreformed House, 1:39, 78-79; Thorne, House of Commons, $1: 37-38$.

${ }^{15}$ P. D. Brett, "The Newcastle Election of 1830," Northern History 24 (1988):101; G. E. Mingay, English Landed Society in the Eighteenth Century (London: Routledge \& Paul, 1963), p. 121; Frank O'Gorman, "The Unreformed Electorate of Hanoverian England: The Mid Eighteenth Century to the Reform Act of 1832," Social History 11 (1986):37.

${ }^{16}$ Brett, "Newcastle," p. 101. See also [Mrs.] Eric George, "'Fox's Martyrs': The General Election of 1784," Transactions of the Royal Historical Society: ser. 4, 21 (1939) :154.

${ }^{17}$ Porritt, Unreformed House, 1:40; and Gash in Politics in the Age of Peel did mention some women. He was quite detailed about Miss Peirse and Miss Lawrence. But he gave few details on individual women's actions in individual campaigns. The following are the best sources for women Porritt, Unreformed House; Thorne, House of Commons; Lewis B. Namier \& John Brooke, House of Commons, 1754-1790, 3 vols. (London: Her Majesty's Stationery Office for the History of Parliament Trust, 1964); and Gash, Politics in the Age of Peel.

\footnotetext{
${ }^{18}$ Two authors made a distinction between nomination and influence. Phillips said there was a "thin line separating"
} 
the two. The political influence exerted by most patrons allowed a considerable degree of political activity by the public, in contrast to the power of nomination which left the voters without a real choice. Only very few patrons possessed nomination. Phillips, "Structure," p. 78; James A. Sack, "House of Lords and Parliamentary Patronage in Great Britain, 1802-1832," Historical Journal 23 (1980): 915 . However, I made no distinguish between influence and nomination for the purpose of this thesis.

${ }^{19}$ O Gorman, "Unreformed, " p. 48.

${ }^{20}$ Lewis, "Political Behavior," p. 253.

${ }^{21}$ Ibid., p. 253 .

${ }^{22}$ Karl Von den Steinen, "The Fabric of Interest in the County: The Buckinghamshire Election of 1784," Albion 4 (1972):206. For the individual patron its "purpose was to provide a seat parliament for himself and for any of his relatives, regardless of their political complexion." Owen, "Political Patronage," p. 379.

${ }^{23}$ Thorne, House of Commons, $2: 254-255$.

${ }^{24}$ Donald E. Ginter, comp., Whig organization in the General Election of 1790: Selected From the Blair Adams papers (Berkeley: University of California Press, 1967), $p$. 253.

${ }^{25}$ Davies, "Aristocratic," pp. 44-45.

${ }^{26}$ Lady Bute to Bruce 8 Aug 1853 quoted in Davies, "Aristocratic," p. 48. An earlier Lady Bute controlled the borough of Bossiney during the last half of the eighteenth century. Thorne, House of Commons, $2: 46$.

${ }^{27}$ But even she only controlled one of the two seats. Alan J. Heesom, "The Sunderland By-Election September 1841," Northern History 9 (1974):64.

${ }^{28}$ Brian Bonsall, Sir James Lowther and Cumberland and Westmoreland Elections, 1754-1775 (Manchester, England: Manchester University Press, 1960), p. 2 .

${ }^{29}$ Peter Burroughs, "The Northumberland County Elections of 1826," Parliamentary History 10 (1991):85. See also Gash, Politics in the Age of Peel, p. 164, for information about the Duchess of Somerset. 
${ }^{30}$ Margaret Maria, Lady Verney, ed., Verney Letters of the Eighteenth Century. From the MSS at Claydon House, 2 vols. (London: E. Benn, 1930), 2:289, 308. See also Ginter, Whig Organization, p. 152, for another example of political parties influencing women electoral patrons.

${ }^{31}$ Lewis called them "maverick campaigns". Lewis, "Political Behavior," p. 250.

${ }^{32}$ Thorne, House of Commons, 2:293-294.

${ }^{33}$ Mary Anne Lewis selected Disraeli to run for Maidstone in 1837, as part of her control of the borough. She was interested in him and said "They call him my Parliamentary Protege." John A. Phillips, The Great Reform Bill in the Borough: English Electoral Behavior 1818-1841 (Oxford: Clarendon, 1992), pp. 118-119. She later married him.

${ }^{34}$ Lewis, "Political Behavior", p. 250.

${ }^{35}$ Namier \& Brooke, House of Commons, 1:310.

${ }^{36}$ Thorne, House of Commons, 1:39. Her son was Marmaduke Larson.

${ }^{37}$ Bourne, Palmerston, pp. 52-53.

${ }^{38}$ Namier \& Brooke, House of Commons, $1: 32$.

${ }^{39} \mathrm{E}$. Anthony Smith, "Earl Fitzwilliam and Malton: A Proprietary Borough in the Early Nineteenth Century, " English Historical Review 80 (1965):61, note 4 .

${ }^{40} \mathrm{O}$ 'Gorman, "Unreformed," p. 48.

${ }^{41}$ Smith, "Earl Fitzwilliam," p. 52.

${ }^{42}$ Davies, "Aristocratic," p. 37.

${ }^{43}$ In 1790, for example, a Commons seat cost about 5,000 pounds. Stokes, Devonshire House, p. 9.

${ }^{44}$ Porritt, Unreformed House, $1: 40$.

${ }^{45}$ Bonsall, Sir James Lowther, p. 18.

${ }^{46}$ Anne Lister, Miss Lister of Shibden Hall: Selected Letters, 1800-1840, ed. Muriel M. Green (Sussex: The Book Guild, 1992), p. 175. See also Jones, "Women and Chartism," p. 76 . 
${ }^{47}$ Verney, Verney Letters, $2: 289$.

${ }^{48}$ Namier \& Brooke, House of Commons, $1: 33$.

${ }^{49}$ Mingay, English Landed Society, p. 123.

${ }^{50}$ Seymour, Electoral, pp. 124-125.

51 "Had John Bottomley, having sent for him to tell him to vote for Wortley tomorrow. Had quarter hour's talk. He promised to vote for him. They had all been at him [the opposition] and some said they would not employ him again if he would not vote their way, but he told them how I wanted him to vote. It is quite useless to leave such men as he uninfluenced. He knows nothing and cares nothing about it and is literally best satisfied with the idea of pleasing somebody he knows." 11 Dec 1832, Lister, Miss Lister, $p$. 174 .

${ }^{52}$ Gash, Politics in the Age of Peel, p. 175. No name given.

53 "Had Throp in. If I could get him his shop window made and a new roof he would vote as I liked all his life. He has no vote this time because his landladies pay the taxes." Anne Lister, 12 Dec 1832, in Miss Lister, p. 174.

${ }^{54}$ Namier \& Brooke, House of Commons, $1: 414$.

${ }^{55}$ Lister, Miss Lister, p. 17.

${ }^{56}$ Hester Lynch Salusbury Thrale Piozzi, Autobiography: Letters and Literary Remains of Mrs. Piozzi (Thrale), edited by A. Hayward, 2 vols., 2nd ed. (London: Longman, 1861), $1: 70$.

${ }^{57}$ Smith, "Earl Fitzwilliam," p. 545.

${ }^{58}$ Davies, "Aristocratic," p. 38.

${ }^{59}$ Lord Bute to Richards, 17 Jan 1825, quoted in Davies, "Aristocratic," p. 38.

${ }^{60}$ Quoted in Mingay, English Landed Society, p. 124.

${ }^{61}$ Adrian Courtney, "Cheltenham Spa and the Berkeleys, 1832-1848: Pocket Borough and Patron?," Midland History 47 (1992): 103 . 
${ }^{62}$ Lady Granville to Lady George Morpeth, 11 Oct 1811, Granville, Letters of Harriet, p. 23. Lord Granville represented Staffordshire.

${ }^{63}$ Lady Spencer to Georgiana, 26 August 1784, Bessborough, Georgiana, p. 77.

${ }^{64}$ Quoted in Mayne, Regency Chapter, p. 48.

${ }^{65}$ Other prominent women electoral patrons included the following: Lady Basset at Truro and Penryn, Dod, Charles R. Dod's, p. 245; Lady Rolle at the county of Devon, Dod, Charles R. Dod's, p. 86; Mrs. Gordon in Wigtown, Dod, Charles R. Dod's, p. 344; Countess of Bath at Weymouth, Thorne, House of Commons, 2:143; Lady Holderness at Dover, Ginter, Whig Organization, p. 141; Lady Pembroke in Nottingham, John Ashton Cannon, Aristocratic Century: The Peerage of the Eighteenth-Century (Cambridge, England: Cambridge University Press, 1984), p. 23; Lady Ambercromby in Clackmannanshire, Sack, "House of Lords," pp. 931, 939; Countess of Strathmore in Durham, Dod, Charles R. Dod's, p. 103; Lady Andover at Castle Rising in Norfolk, Cannon, Aristocratic Century, p. 110; Namier \& Brooke, House of Commons, 1:340; Lady Burlington in Knaresborough, Namier \& Brooke, House of commons, 1:435; Miss Peirse in Northallerton in Yorkshire, Dod, Charles R. Dod's, pp. 228-229; Gash, Politics in the Age of Peel, p. 219.

${ }^{66}$ At St. Albans when a third candidate arrived she herself dealt with the election agent. The candidate was Arthur Hill, a brother of Lady Salisbury, who campaigned for him. Namier \& Brooke, House of Commons, 1:309-310. $1: 309-310$.

${ }^{67} 1$ April 1784. Namier \& Brooke, House of Commons,

${ }^{68}$ Harriet Spencer, Countess of Bessborough, "Lady Duncannon's Diary" (Mar-Apr 1789)," in Lady Bessborough and Her Family Circle, ed. Earl of Bessborough (London: John Murray, 1940), p. 7 .

${ }^{69}$ Bessborough, Family Circle, p. 145.

${ }^{70}$ Bessborough, Family Circle, p. 229. Masters believed that Lady Spencer thought politics were not a proper subject to interest a lady and that elections were "vile things." Masters, Georgiana, p. 5. Bessborough said Lady Spencer "described elections as "vile things, occasioning a deplorable waste of time, money, and temper." Bessborough, Family Circle, p. 148. 
${ }^{71}$ Bessborough, Family Circle, p. 149.

${ }^{72}$ Ibid. , pp. 157-158.

${ }^{73}$ Thorne, House of Commons, $2: 208$.

${ }^{74}$ From 1778 when her husband died until 1807 when she died. Horsham had 24 voters in 1790 and 73 in 1807 . Its population was 3,204. Thorne, House of Commons, 2:208. See also Bourne, Palmerston, pp. 65-79, and William Albery, $\underline{A}$ Parliamentary History of the Ancient Borough of Horsham, 1295-1885 (London: Longmans, Green, 1927), pp. 114-255.

${ }^{75}$ Charles, 11th Duke. He was the "Jockey of Norfolk" and a strong supporter of Charles James Fox.

${ }^{76}$ Albery, Parliamentary History, p. 242. After saying this radical statement, the author of course has to point out that she was also of course beautiful and a good wife and mother.

${ }^{77}$ Albery, Parliamentary History, p. 252. Albery presents a whig point of view.

${ }^{78}$ Palmerston, Third Viscount Palmerston, p. 68, note 1 .

${ }^{79}$ Albery, Parliamentary History, p. 131. A faggot-vote was created when new burgages were erected.

${ }^{80}$ Thorne, House of Commons, 2:458. The population in 1801 was 3,211. George Aislabie was the founder of the Lawrence estates in Yorkshire. He died in 1742. His only son, William, inherited and was MP for Ripon from 1721-1781. He died leaving two daughters, Elizabeth and Anna Sophia, mother of Elizabeth. Gash, Politics in the Age of Peel, $p$. 220 .

${ }^{81}$ Quoted in Gash, Politics in the Age of Peel, p. 221.

${ }^{82}$ Gash, Politics in the Age of Peel, p. 221.

${ }^{83}$ "From 1837-1845, it was clear that Ripon was not only under the control of its proprietress, but also at the disposal of the conservative party." Dod, Charles R. Dod's, p. 263 .

${ }^{84} \mathrm{Gash}$, Politics in the Age of Peel, p. 221. 
${ }^{85}$ The preliminary canvass was almost a private poll to show the candidate and his patron if the candidate should risk a public poll. The nomination was often a formality, done by a vote of hands. Then came the official vote, or the poll. Donald R. McAdams, "Electioneering Techniques in Populous Constituencies, 1784-96," Studies in Burke and His Time 14 (1972):23-30. See also the introduction of Hanham Dod for details of each step in the process.

${ }^{86} \mathrm{All}$ election expenses were born by the candidate, patron, and some supporters. There was no national party organization. The expenses for a four step election ranged from over 100,000 pounds in the 1807 county of Yorkshire election to a mere 800 pounds for Fox's 1802 Westminster election. A. Gooder, Parliamentary Representation of the county of Yorkshire 1258-1832, The Yorkshire Archaeological Society Record Series XCI (Wakefield, Yorkshire: West Yorkshire Printing Company, 1935), 2:154; McAdams, "Electioneering," p. 45.

${ }^{87}$ Morning Post, 20 April 1784.

${ }^{88} \mathrm{E}$. Anthony Smith, "The Yorkshire Elections of 1806 and 1807: A Study in Electoral Management," Northern History 9 (1974):80. See also Frank O'Gorman, Voters, Patrons, and Parties: The Unreformed Electoral system of Hanoverian England, 1734-1832 (Oxford: Clarendon Press, 1989), pp. 92-93.

${ }^{89} \mathrm{E}$. Anthony Smith, "The Election Agent in English Politics, 1784-1832," English Historical Review 84 (1969):15.

${ }^{90}$ O'Gorman, Voters, Patrons, p. 93. Women and men frequently showed their support for their candidate by wearing his colors and emblems.

${ }^{91} \mathrm{~J}$. Grego, History of Parliamentary Elections and Electioneering From the stuarts to oueen Victoria (London: Chat to \& Windus, 1892), p. 293.

\section{${ }^{92}$ Morning Post, 20 April 1784.}

${ }^{93}$ Five years later Lady Salisbury was so confident of her canvassing efforts for her son, that she informs the Prime Minister that there was no danger of a contest. Thorne, House of Commons, 2:203.

${ }^{94}$ Hester Lynch Salusbury Thrale Piozzi, Thraliana: The Diary of Mrs. Hester Lynch Thrale (Later Mrs. Piozzi), 
1776-1809, ed. Katherine C. Balderston, 2 vols. (Oxford: The Clarendon Press, 1942), 2:436.

${ }^{95}$ Heesom, "Sunderland," pp. 69-76. She was successful with 6 of the 9 .

${ }^{96}$ Stokes, Devonshire House, p. 199; Palmerston, Third Viscount Palmerston, p. 62 .

${ }^{97}$ Lady Spencer to Georgiana, 9 Oct 1774, Bessborough, Georgiana, p. 92 .

${ }^{98}$ Granville, Iord Granvilie Leveson Gower Private Correspendence, 1:10.

${ }^{99}$ Granville, Lord Granville Leveson Gower Private Correspondence, $1: 25$.

${ }^{100}$ Arbuthnot, Journals of Mrs. Arbuthnet, 1:196. However, Mr. Bankes's opponent was a nephew of Lord Liverpool, the Tory Prime Minister. Mrs. Arbuthnot had lots of explaining to do, Lewis, "popular Behavior", p. 250-251.

${ }^{101}$ Greville, Greville Memoirs, p. 7. Other examples of women canvassing for non-family members were Anne Lister who canvassed heavily for the Tory party in 1837 in Jones, "Women and Chartism," p. 76; Lady Elizabeth Foster in connection with Sheridan's election in 1784 in Henrietta Elizabeth Leveson Gower Granville, Hary-0: The Letters of Lady Harriet Cavendish, 1796-1809, eds. Sir George Leveson Gower and Iris Palmer (London: John Murray, 1940), p. 155; Georgiana for Granville in 1795 in Villiers, Grand Whiggery, p. 148 .

${ }^{102}$ Lord Ellenborough's diary, 25 Mar 1831. Anne was Lord Ellenborough's sister who married Lord Colville in 1841. Aspinall, Three Early, p. 73 .

${ }^{103}$ Lady Shelley for 1819 Westminster election, 22 Feb 1819, in Diary of Lady Shelley, $2: 29$.

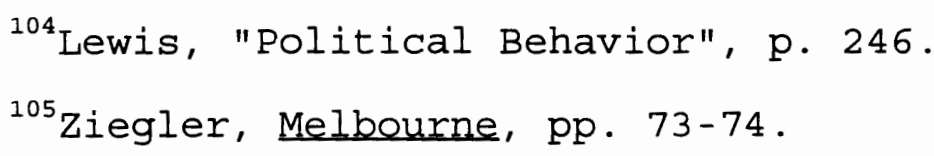

${ }^{106}$ Julian R. McQuiston, "Sussex Aristocrats and the County Election of 1820," English Historical Review 88 $(1973): 548$.

$$
{ }^{107} \text { Lee, Wives, p. } 113 .
$$


${ }^{108}$ Frank O'Gorman, "Campaign Rituals and Ceremonies: The Social Meaning of Elections in England 1780-1860," Past \& Present 135 (1992):84-86.

${ }^{109}$ O'Gorman, "Campaign Rituals," p. 95.

${ }^{110} \mathrm{Elliot}$, Life and Letters, $1: 363$.

${ }^{111}$ Morning Post, 20 April 1784.

${ }^{112}$ Phillips, "structure," p. 97.

${ }^{113}$ Ralph Arnold, The Unhappy Countess and Her Grandson John Bowes (London: Constable, 1957), pp. 77-78.

${ }^{114}$ Cecil, Life of Robert, p. 2 .

${ }^{115}$ Gillett, History of Grimsby, p. 171.

${ }^{116}$ Thorne, House of Commens, $1: 12$.

${ }^{117}$ A. M. W. Stirling, coke of Norfolk and His Friends: The Life of Thomas William coke, The First Earl of Leicester of Holkham, 2 vols. (London: John Lane The Bodley Head, 1908), 1:219-220.

${ }^{118}$ Quoted in Robert D. Bass, The Green Dragoon or The Lives of Banastre Tarleton and Mary Robinson (New York: Henry Holt, 1957), p. 234.

${ }^{119}$ For her candidate lover, Tarleton. Bass, Green Drageon, p. 285. At the age of 16, Charlotte Elizabeth Browne (1790-1846) was writing political squibs, used at elections Ida Beatrice O'Malley, women in Subjection: A study of the Lives of Englishwomen Before 1832 (London: Duckworth, 1933), pp. 222-223.

${ }^{120}$ Georgiana Spencer, Duchess of Devonshire, "Selections From the Letters of Georgiana, Duchess of Devonshire by the Duchess of Devonshire," ed. Duchess of Devonshire, Anglo Saxon Review (June 1899):226.

${ }^{121}$ Granville, Lord Granville Leveson Gower Private Correspondence, 1:99.

${ }^{122}$ Northumberland, Diary of a Duchess, p. vii.

${ }^{123}$ Stokes, Devonshire House, p. 199. 
${ }^{124}$ Mrs. Delaney quoted in Stokes, Devonshire House, pp. 198-199.

${ }^{125}$ Stokes, Devonshire House, p. 199. She was aged 58 during the 1774 election. Her diaries have been published, unfortunately they stop before this time period; see Northumberland, Diary ef a Duchess.

${ }^{126}$ Smith, "Yorkshire Elections," p. 80.

${ }^{127}$ Smith, "Yorkshire Elections," p. 80. Lady Jane got 16 votes for Milton and all were plumpers. Each voter had two votes. He could split them between the candidates or vote for only one-called a plumper. He could not give two votes to one candidate.

${ }^{128}$ Smith, "Yorkshire Elections," p. 81.

${ }^{129}$ York Herald 13 June 1807 quoted in Smith, "Yorkshire Elections," p. 80, note 76 . She also was toasted at Milton's victory dance as "The female patriot of Yorkshire" York Herald 13 June 1807 quoted in Smith, "Yorkshire Elections," p. 80 , note 76 .

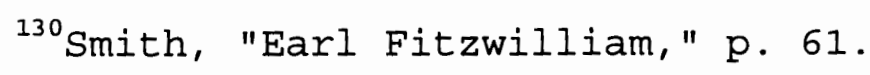

${ }^{132}$ Ibid., p. 67, note 4. This is ironic, coming from a man who spent his life living to hunt and shoot. She always pushed him to stand for election, but he hated it.

${ }^{133}$ Sir S. Romilly committed suicide in 1819, resulting in an election for his seat at Westminster. In this election, Lamb ran as a Whig against the Radicals, John Cam Hobhouse and Cartwright. Lamb won and Hobhouse came in second. However, the king died the next year and new elections were held in 1820. This time Lamb placed third against Burdett and Hobhouse.

${ }^{134}$ Lieven to Metternich, 11 March 1820. Dorothea Lieven, The private Letters of Princess Lieven to Prince Metternich, 1820-1926, ed. Peter Quennell (London: John Murray, 1937), p. 20.

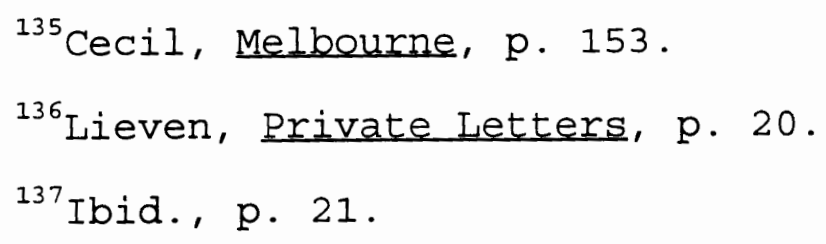


${ }^{138}$ Malcolm I. Thomis, Politics and Society in Nottingham 1785-1835 (New York: Augustus M. Kelley, 1969), p. 161.

${ }^{139}$ Norman Charles Phillips, Yorkshire and English National Politics, 1783-1784 (Christchurch, New Zealand: University of Canterbury Press, 1961), p. 7.

${ }^{140}$ Lascelles, Life of Charles James Fox, p. 149.

${ }^{141}$ D'Arblay, Diary and Letters, $4: 97$.

${ }^{142}$ Sichel, Sheridan, 1:61.

${ }^{143}$ William Connor Sydney, England and the English in the Eighteenth Century: Chapters in the social History of the Time, 2 vols., 2nd ed. (London: Ward \& Downey, 1892), 2:177. There was only one voting booth for the entire borough, in Covent garden.

${ }^{144}$ Letter to Horace Mann, 36 April 1784, Horace Walpole's Correspondence, 25:496.

${ }^{145}$ Brian Masters, Georgiana, Duchess of Devonshire (London: Hamish Hamilton, 1981), p. 120. This does not even count the prints that concerning other women campaigners.

${ }^{146}$ Sichel, Sheridan, 1:62. Most modern historians agree that Georgiana's work was the key to Fox's victory. Some earlier historians deny it. Laprade stated that Georgiana was only useful for transporting voters to the polls. William Thomas Laprade, "William Pitt and the Westminster Elections," American Historical Review 18 (1913):264. After the election, Pitt made a speech in Parliament explaining why he, the crown, and the East India Company could not defeat Fox. He attributed it to Georgiana's campaigning Hansard Parl Hist xxiv p. 842 quoted in Laprade, William Pitt, p. 264.

${ }^{147}$ Sichel, Sheridan, $2: 61$.

${ }^{148}$ Reid, Charles James Fox, p. 200.

${ }^{249}$ The Duke of Portland was the nominal head of the Whig party and also was her husband's brother-in-law.

${ }^{150}$ Stokes stated that Georgiana was "eager for notoriety" in Devonshire House, p. 192. 
${ }^{151}$ Men also canvassed during this election. "Virtually every politician who could attend canvassed on one side or the other in 1784." McAdams, "Electioneering," p. 33.

${ }^{152}$ Sydney, England, $2: 179$.

${ }^{153}$ Lascelles, Life of Charles James Fox, p. 153.

${ }^{154}$ Stokes, Devonshire House, p. 199.

${ }^{155}$ Letter of Lord Fife to William Rose, 29 April 1784. Taylor Lord Fife and his Factor, London, 1926, p. 105, quoted in McAdams, "Electioneering," p. 33, n. 5.

${ }^{156}$ Sichel, Sheridan, 1:60.

${ }^{157}$ Stokes, Devonshire House, p. 202.

${ }^{158}$ Calder-Marshall, Two Duchesses, p. 62 .

${ }^{159}$ Brian Masters, The Dukes The Origins: Ennoblement and Histery of 26 Eamilies (London: Blond \& Briggs, 1975), $p$. 124. see also Morning Post, 20 April 1784.

${ }^{160}$ Morning Post, 20 April 1784.

${ }^{161}$ Calder-Marshall, Twe Duchesses, p. 62.

${ }^{162}$ Georgiana to her mother, Lady Spencer, March 1784, Georgiana spencer, Duchess of Devonshire, "Selections From the Letters of Georgiana, Duchess of Devonshire by the Duchess of Devonshire," ed. Duchess of Devonshire, Angle Saxon Review (September 1899): 73 .

${ }^{163}$ Stokes, Devonshire House, p. 202.

164 "The Heir Apparent spent hours discussing the details of the contest at Devonshire House." Stokes, Devonshire House, p. 195. However, Stokes in the very next sentence stated that Georgiana and the Prince were having an affair. This accusation, although false, diminishes the Georgiana's stature.

${ }^{165}$ Villiers, Grand Whiggery, p. 68.

${ }^{166}$ Whig women and carried the banners "Fox and Liberty" and the Tory women "Pitt and Constitution." Masters, Georgiana, p. 123. 
${ }^{167}$ Georgiana to Lady Spencer, April 1784, Devonshire, "Selections," (September 1899):75.

${ }^{168}$ Wraxall, Posthumous Memoirs, p. 16.

${ }^{169}$ Blue referred to the buff and blue colors of Fox. As a result of her support in this election, and subsequent ones, Fox raised her husband to the peerage in 1806 when the Whigs came to power. Stokes, Devonshire House, p. 204.

${ }^{170}$ Lascelles, Iife of Charles James Eox, p. 154.

${ }^{171}$ Morning Post, 13 April 1784.

${ }^{172}$ Wraxal1, Posthumous, p. 14.

${ }^{173}$ Stokes, Devonshire House, p. 201.

${ }^{174}$ Wraxal1, Rosthumous, p. 14. She also was too old to be effective. This was an age of youth. Georgiana and the Prince were in their early twenties and Fox and Sheridan were in their early thirties.

${ }^{175}$ Grego, History of Parliamentary, p. 271.

${ }^{176}$ Henry Dundas, Melville, MSS n.d. quoted in George II, Later Correspondence, 1:164.

${ }^{177}$ Letter Georgiana to Lady Spencer, March 1784, in Devonshire, "Selections," (September 1899):73. 
CHAPTER VI

CONCLUSION

British aristocratic women played a powerful and continuing role in politics during the mid-eighteenth to midnineteenth century. Their political power stemmed from three factors - the family foundation of politics, the close interconnection between politics and society, and the small size of the elite. First, the foundation of the political system was family and family interests. Politics was an acceptable career for heirs (Commons then on to the Lords) and for younger sons. Women were a vital part of this structure. They saw themselves as part of the society that ruled Britain, not as weak outsiders looking in. They were trained from childhood for their political role. We can especially see the familial/ political power of women through a study of the Whig Aristocracy or the Grand Whiggery. The continued existence of the Whig party depended upon its women. Without the Whig women political hostesses, patronage directors, political advisors, and electioneers the whig party would have ceased to be during its long hiatus out of power in the last quarter of the eighteenth century. There 
was no national political party organization. Political ties were family ties, with the result that British aristocratic women had larger impact on politics.

Second, contemporaries made little distinction between politics and society. Powerful social leaders were also powerful political leaders. Thus while British aristocratic women controlled who was socially acceptable, they also controlled who was politically acceptable. The contemporary nexus of politics and society depended upon and was established by the power of British aristocratic women.

Third, the size of elite society was small. It consisted of a few hundred families of aristocrats who ruled both society and politics. Where the ruling class was small, women could have greater impact and wield greater power.

British aristocratic women played four major roles in the political structure of the time period--political hostess, director of patronage, political advisor, and electioneer.

Political hostesses determined who was and was not politically acceptable. They also determined the direction of politics by controlling who met whom and who discussed what. Politicians created consensuses and tested the waters from the early days at Melbourne House to the later days at the homes of Lady Cowper and Lady Holland. There were three major aspects of political hostessing (invitation control, 
creation of neutral ground, and the vetting of political talent) that illustrate British aristocratic women's great political power and influence. The British political salons developed along with and were a necessary component of the nexus of politics and society of the period. The political salons served as alternative seats of political power, especially for the Whigs, who were to begin a long hiatus from power.

Patronage was the process of obtaining government posts for family, friends, constituents, and others. Political patronage was central to the working of the political/social nexus. Patronage depended upon the directing ability of British aristocratic women.

The major male political leaders depended upon the political advising role of British aristocratic women. They frequently and continually brought information to women and sought information from women. British aristocratic women were not shut out of the political establishment. Instead they created and sustained an information network upon which the socio-political structure depended. Although British aristocratic women did not necessarily originate the political information, it was the women who controlled this flow of political currency. They did this through the functions of their role of political advisors-intermediaries, political whips, and issues advisors. 
The examples show that British aristocratic women indeed wielded great political power through their dual electioneering roles of patron and campaigner. Women were patrons throughout much of England and Scotland, controlling the nominations of many members of Parliament. Women also campaigned in many elections throughout Britain during the time period covered by this thesis. The socio-political system, based upon family ties, and especially the lack of a national party organization, demanded this role from women.

There is nothing unique about women's political activities during this period. Each of the four roles was also performed by men. Women may have given more dinners, but there were many stag affairs also. Women may have placed people in positions but it was with an the appointive power of men. Men, as well as women, advised and electioneered. Women ran society and directed the flow of politics, but men were involved.

Researching this topic was frustrating at times. On one hand, we have large amounts of available primary material. There are numerous published collections of letters, diaries, and journals of both women and men. For example, we are able to trace, through published letters, four generations of political activity of spencer women. These provide valuable material, demonstrating the political power of women. On the other hand, this time period has been 
on the whole ignored by both historians and women's historians. There are very few historians writing on this period, and only rarely do they discuss women. There is a great need to shift the focus on the definition of what we consider politics to be. Women could not vote or be a Member of Parliament. Yet, that did not mean they could not decide and control who were members, or advise others how to vote.

Women's historians have almost completely ignored this period also. They conveniently skip from Sarah, Duchess of Marlborough to the late Victorian agitators for women's rights. Women's historians saw so much promise in the feminism of the early eighteenth century with Mary Astell, that they tended to believe the women in the next one hundred years were failures for not fulfilling the expectations. However, through a study of British aristocratic women and their political activities of political hostessing, patronage directing, political advising, and electioneering we can see powerful British aristocratic women were from 1760-1860. 
REFERENCES

Abbott, Charles. The Diary and Correspondence of Charles Abbott, Lord Colchester, Speaker of the House of commons 1802-1817. Edited by Charles Abbott, Lord Colchester. 3 vols. London: Murray, 1861.

Airlie, Mabell Frances Elizabeth Gore Ogilvy, Countess of. In whig Society, 1775-1818. Compiled From the Hitherto Unpublished Correspondence of Elizabeth. Viscountess Melbourne and Emily Iamb, Countess Cowper, Afterwards Viscountess Palmerston. London: Hodder and Stroughton, 1921.

- Lady Palmerston \& Her Times. 2 vols. London: Hodder \& Stroughton, 1922.

Albery, William. A Parliamentary History of the Ancient Borough of Horsham, 1295-1885. London: Longmans, Green, 1927.

Alexander, Sally. "Woman, Class, and Sexual Differences in the 1830s and 1840s: Some Reflections on the Writings of a Feminist History." History Workshop Journal 17 (1984): $125-149$.

Anderson, Bonnie. A History of Her Own. 3 vols. New York: Harper \& Row, 1988, 1989.

Anderson, William. Scottish Nation. 3 vols. Edinburgh: A. Fullerton, 1863.

Arbuthnot, Charles. The correspondence of charles Arbuthnot. Edited by Arthur Aspinall. London: Royal Historical Society, 1941.

Arbuthnot, Harriet Fane. The Journals of Mrs. Arbuthnot, 1820-1832. Edited by Francis Bamford and the Duke of Wellington. 2 vols. London: Macmillan, 1950.

Arbuthnot, P. S. M. Memoirs of the Arbuthnots of Kincardineshire and Aberdeenshire. London: Allen \& Unwin, 1920.

Arnold, Ralph. The Unhappy Countess and Her Grandson John Bowes. London: Constable, 1957. 
, ed. The Correspondence of George, Prince of Wales (1770-1812). New York: Oxford University Press,

1967-71.

, ed. Formation of Canning's Ministry, February to August 1827. Edited From Contemporary Correspondence. Camden Miscellany 3rd Series, vol. 59. London: Royal Historical Society, 1937.

- Iord Brougham and the Whig Party (Publication \#179). Manchester, England: Manchester University Press, 1927; reissued 1939; reprint ed., Hamden, CT: Archon Books, 1972 .

- "The Reporting and Publishing of the House of Commons Debates, 1771-1834." In Essays Presented to Sir Lewis Namier, pp. 227-257. Edited by Richard Pares and A. J. P. Taylor. London: Macmillan, 1956.

- Three Early Nineteenth Century Diaries. London: Williams \& Norgate, 1952 .

, ed. Parliament Through Seven Centuries: Reading and Its M.R.s. London: Cassell, 1962 .

Aspinall, Arthur, and Smith, E. Anthony. English Historical Documents, 1783-1832. New York: Oxford University Press, 1959; London: Oxford University Press, 1959.

Bartlett, C. J. Castlereagh. London: Macmillan, 1966.

Bass, Robert D. The Green Drageon or The Iives of Banastre Tarleton and Mary Robinson. New York: Henry Holt, 1957.

Beales, D. E. D. "Parliamentary Parties and the 'Independent Member,' 1810-1860." In Ideas and Institutions of Victorian Britain, pp. 1-19. Edited by Robert Robson. New York: Barnes \& Noble, 1967.

Bean, William Wardell. The Parliamentary Representation of the Six Northern Counties of England: Cumberland, Durham, Lancashire, Northumberland, Westmoreland, and Yorkshire, and other Cities and Boroughs; from 1603 , to the General Election of 1886 , With Lists of Members and Biographical Notices. Hull, England: C. H. Barnwel1, 1890; photocopy reprint, Ann Arbor, MI: University Microfilms International, 1894. 
Beckett, J. V. The Aristocracy in England, 1660-1914.

Oxford: Basil Blackwell, 1986. "The English Aristocracy." Parliamentary History
7 (1988):241-256.

Bedingfield, Lady Charlotte. The Jerningham Letters (1740-1843): Being Excerpts from the Correspondence and Diaries of the Honorable Lady Jerningham and Her Daughter Lady Bedingfield (1809-1833). Edited by Egerton Castle. 2 vols. London: Bentley, 1896.

Benkovitz, Miriam J. "Some Observations on Women's Concept of self in the 18th Century." In Man Versus Society in Eighteenth-Century Britain: Six Points of View, pp. 1-21. Edited by James L. Clifford. Cambridge, England: Cambridge University Press, 1968.

Bernier, Oliver. The Eighteenth Century Woman. New York: Doubleday and the Metropolitan Museum of Art, 1981.

Berry, Mary, Miss. Extracts of the Journals and Correspondence of Miss Berry From the Year 1783-1852. Edited by Lady Theresa Lewis. 3 vols. London: Longmans, Green, 1865.

Bessborough, Harriet Spencer, Countess of. "Lady Duncannon's Diary (Mar-Apr 1789)." In Lady

Bessborough and Her Family Circle, pp. 43-53. Edited by the Earl of Bessborough. London: John Murray, 1940 .

Bigham, Clive. The Prime Ministers of Britain, 1721-1921. London: John Murray, 1924.

Billington, Louis, and Billington, Rosamund. "A Burning Zeal for Righteousness: Women in the British Anti-Slavery Movement, 1820-1860." In Equal or Different: Women's Politics 1800-1914, pp. 82-111. Edited by Jane Rendall. Oxford: Basil Blackwell, 1987 .

Birkenhead, Sheila Berry Smith, Countess of. Peace in Picadilly: The Story of Albany. New York: Reynal, 1958 .

Black, Eugene C., ed. British Politics in the Nineteenth Century. New York: Walker, 1969. 
Black, Jeremy M., ed. Britain in the Age of Walpole. Basingstoke, Hampshire: Macmillan, 1984.

- British Politics and Society From Walpole to Pitt 1742-1789. Basingstoke, Hampshire: Macmillan, 1990.

The English Press in the Eighteenth Century. Philadelphia: University of Pennsylvania Press, 1987.

- "Party Politics in Eighteenth Century Britain." Lamar Journal of the Humanities 15 (1989):27-38.

- Ritt the Elder. Cambridge, England: Cambridge University Press, 1992 .

"The Tory View of Eighteenth Century British Foreign Policy." Historical Journal 31 (1988) : 469-477.

Blackburne, Neville. Ladies' Chain. London: Falcon Press, 1952 .

Blain, Virginia. The Feminist Companion to Literature in England: Women Writers From the Middle Ages to the Present. New Haven, CT: Yale University Press, 1990.

Blakiston, Georgiana. Lord William Russell and His Wife 1815-1846. Wilmington, DE: Scholarly Resources, 1972.

Blease, Walter Lyon. The Emancipation of English Women. London: Constable and Co., 1910; reprint ed., New York: Arno Press, 1977.

Bohstedt, John. "Gender, Household and Community Politics: Women in English Riots 1790-1810." Past \& Present 120 (1988) : 88-120.

Bonsall, Brian. Sir James Lowther and Cumberland and Westmoreland Elections, 1754-1775. Manchester, England: Manchester University Press, 1960.

Boswell, James. Boswell's Life of Johnson. Edited by George Birkbeck Hill, revised by L. F. Powell. 6 vols. Oxford: Clarendon, 1934.

Boulton, William B. Amusements of old London. London: J. C. Nimmo, 1901; reprint ed., New York: Benjamin Blom, 1969 . 
. In the Days of the Georges. New York: James Pott, 1910 .

Bourne, J. M. Patronage and Society in Nineteenth Century England. London: E. Arnold, 1986.

Bourne, Kenneth. Palmerston: The Early Years 1784-1841. New York: Macmillan, 1982.

Bradford, Gamaliel. Portrait of Women. Boston: Houghton, Mifflin, 1916.

Brett, P. D. "The Newcastle Election of 1830." Northern History 24 (1988):101-123.

Briggs, Asa. "Social Structure and Politics in Birmingham and Lyons 1825-1848." British Journal of Sociology 1 $(1950): 66-80$.

Bromhead, Peter A. The House of Lords and Contemporary Politics, 1911-1957. London: Routledge and Paul, 1958 .

Brophy, Elizabeth Bergen. Women's Lives of the Eighteenth Century English Novel. Tampa: University of South Florida, 1991 .

Brown, Susan E. "Rational Creatures and Free Citizens: The Language of Politics in the Eighteenth-Century Debate on Women." Canadian Historical Association: Historical papers (1988):35-47.

Buckingham and Chandos, Richard Plantagenet Temple, Duke of. Memoirs of the Court of England During the Regency 1811-1820 From Original Family Documents. 2 vols. London: Hurst \& Blackett, 1856.

Memoirs of the Court and Cabinets During the Reign of George the Third From Original Family Documents. 2 vols. London: Hurst \& Blackett, 1853, 1855 .

Bulmer, Thomas. The Growth of the British Party System. 2nd ed., 2 vols. London: John Baker, 1967.

Burke, Edmund. Correspondence of Edmund Burke. 10 vols. Cambridge, England: Cambridge University Press, 1978; Chicago: University of Chicago Press, 1978. 
Burroughs, Peter. "The Northumberland County Elections of 1826." Parliamentary History 10 (1991):78-104.

Burton, Elizabeth. The Pageant of Georgian England. New York: Charles Scribner's Sons, 1967.

Bury, Charlotte. The Diary of a Lady-in-Waiting. Edited by A. Francis Steuart. 2 vols. London: John Lane, 1908.

Bush, M. L. English Aristocracy: A Comparative Synthesis. Manchester, England: Manchester University Press, 1984 .

Byron, George Gordon, Baron. Byron's Letters and Journals. The Complete and Unexpurgated Text of All the Letters Available in Manuscript and the Full printed Version of All others. Edited by Leslie Marchand. 11 vols. Cambridge: Harvard University Press, Belknap Press, 1973-81.

Caine, Barbara. Victorian Feminists. London: Oxford University Press, 1992.

Calder-Marshall, Arthur. The Grand Century of the Lady. London: Gordon Cremonesi, 1976.

The Two Duchesses. 1st U.S. ed. New York: Harper \& Row, 1978.

Cannadine, David. Lords and Landlords: The Aristocracy and the Towns, 1774-1967. Leicester, England: Leicester University Press, 1980.

, ed. Patricians, Power, and Politics in Nineteenth Century Towns. Leicester, England: Leicester University Press, 1982; New York: St. Martin's Press, 1982 .

Canning, George. The Letter Journal of George Canning 1793-1795. Edited by Peter Jupp. Camden Miscellany 4th Series, vol. 41. London: Royal Historical Society, 1991.

Cannon, John Ashton. Aristocratic Century: The Peerage of the Eighteenth-Century. Cambridge, England: Cambridge University Press, 1984.

\footnotetext{
Fox-North Coalition: Crisis of the Constitution, 1782-84. Cambridge, England: Cambridge University Press, 1969.
} 
"New Lamps for Old: The End of Hanoverian England." In Whig Ascendancy Colloquies on Hanoverian England, pp. 100-118. Edited by John Ashton Cannon. London: Edward Arnold, 1981:

, ed. Whig Ascendancy Colloguies on Hanoverian England. London: Edward Arnold, 1981.

Carswell, John. The old Cause: Three Biographical Studies in Whiggism. London: Cresset Press, 1954.

Cecil, David, Lord. Melbourne. Indianapolis: BobbsMerrill, 1954 .

Cecil, Gwendolen. The Life of Robert, Marguis of Salisbury. 4 vols. London: Hodder and Stroughton, 1921-32.

Charlotte Augusta, Princess of Great Britain. The Letters of the Princess Charlotte 1811-1817. Edited by Arthur Aspinall. London: Home \& Van Thal, 1949.

Christie, Ian R. "The Anatomy of the Opposition in the Parliament of 1784." Parliamentary History 9 (1990): 50-77.

"The Changing Nature of British Parliamentary Politics." In British Politics and Society From Walpole to pitt 1742-1789, pp. 101-122. Edited by Jeremy M. Black. Basingstoke, Hampshire: Macmillan, 1990.

- Myth and Reality in Late Eighteenth Century

British Politics and Other Papers. Berkeley: University of California Press, 1970.

"Party in Politics in the Age of Lord North's Administration." Parliamentary History 6 (1987): 47-68.

- Wilkes, Wyvill and Reform: The Parliamentary Reform Movement in British Politics, 1760-1785. London: Macmillan, 1962.

"The Yorkshire Association, 1780-84: A Study in Political Organization." Historical Journal 3 (1969): 144-161.

Claeys, Gregory. "Whigs, Liberals, and Radicals." Historical Journal 33 (1990):737-745. 
Clark, J. C. D. "Eighteenth-Century Social History: Review Article." Historical Journal 27 (1984):773-788.

English Society 1688-1832: Ideology, Social Structure and Political Practice During the Ancien [t] Regime. Cambridge, England: Cambridge University Press, 1985.

Clifford, James L., ed. Man Versus Society in EighteenthCentury Britain: Six points of View. Cambridge, England: Cambridge University Press, 1968.

Coke, Mary, Lady. The Letters and Journals of Iady Mary coke (1756-1791). Edited by James Archibald Home. 4 vols. Edinburgh: David Douglas, 1889-1896; reprint ed., Bath: Kingsmead Bookshops, 1970.

Colley, Linda. "Politics of Eighteenth-Century British History." Journal of British Studies 25 $(1986): 359-379$.

Connell, Brian. Portrait of a Golden Age: Intimate Papers of the Second Viscount PaImerston, Courtier Under George III, 1739-1802. Boston: Houghton Mifflin, 1958 .

Cornwallis, Charles. Correspondence of Charles, First Marquis Cornwallis. Edited by Charles Ross. 3 vols. London: John Murray, 1859.

Courteney, Adrian. "Cheltenham Spa and the Berkeleys, 1832-1848: Pocket Borough and Patron?" Midland History 47 (1992):93-108.

Cowie, Leonard W. Eighteenth-Century Europe. London: G. Bell and Sons, 1963.

Hanoverian England 1714-1837. London: G. Bell and Sons, 1967.

Cowper, Lord. "Lord Melbourne: A Sketch." Nineteenth Century 15 (1884):49-56.

Creyke, Caroline. "Spa and its English Associations." Nineteenth Century 52 (1902):656-664.

Croker, John Wilson. The Amazoniad or Figure of Fashion: A Scuffle in High Life. Dublin: John King, 1806 
The Croker Papers: The Correspondence of John Wilson croker, Secretary to the Admiralty From 1809-1830. Edited by J. Jennings. London: John Murray, 1884; reprint ed., New York: AMS Press, 1972.

Currell, Melville E. Political women. London: Croom Held, 1974.

Curtis, Edith Roehker. Iady Sarah Lennox: An Irrepressible Stuart 1745-1826. New York: G. P. Putnam's Sons, 1946.

D'Arblay, Francis Burney. Diary and Letters of Madame d'Arblay (1778-1840). Edited by Charlotte Barrett. Preface by Austin Dobson. 6 vols. London: Macmillan, 1904-1905.

- The Early Journals and Letters of Fanny Burney. 1768-1777. Edited by Lars E. Troide. 2 vols. Kingston, Ont.: Queens University Press, 1988, 1990.

Darvall, Frank Ongley. Popular Disturbances and Public Order in Regency England. London: Oxford University Press, 1934; reprint ed., New York: Augustus M. Kelley, 1969.

Davies, John. "Aristocratic Town-Makers and the Coal Metropolis: The Marquis of Bute and the Growth of Cardiff, 1776-1947." In Patricians, Power, and Politics in Nineteenth Century Towns, pp. 18-67. Edited by David Cannadine. Leicester, England: Leicester University Press, 1982.

Davis, Richard W. "Deference and Aristocracy in the Time of the Great Reform Act." American Historical Review 81 (1976): 532-539.

Delany, Mary, Mrs. The Autobiography and Correspondence of Mary Granville, Mrs. Delany. 6 vols. Edited by Lady Llanover. London: R. Bentley, 1861-62; reprint ed., New York: AMS Press, 1974.

Derry, John. Charles James Fox. New York: St. Martin's Press, 1972.

"Governing Temperament Under Pitt and Liverpool." In whig Ascendancy Colloguies on Hanoverian England, pp. 125-145. Edited by John Ashton Cannon. London: Edward Arnold, 1981. 
Devonshire, Deborah Vivien Freman-Mitford Cavendish, Duchess of. The House, Living at Chatsworth. 1st American ed. New York: Holt, Rinehart \& Winston, 1982.

Devonshire, Georgiana, Spencer, Duchess of. "Georgiana, Duchess of Devonshire's Diary 20 Nov 1788 - 12 Jan 1789." In Sheridan, pp. 399-406. Edited by Walter Sichel. London: Constable, 1909.

- Georgiana: Extracts From the Correspondence of Georgiana, Duchess of Devonshire. Edited by the Earl of Bessborough. London: John Murray, 1955.

- "Letters From Sheridan to the Duchess of Devonshire and Her Sister, Lady Bessborough." In Sheridan, pp. 429-441. Edited by Walter Sichel. London: Constable, 1909.

"Selections From the Letters of Georgiana, Duchess of Devonshire by the Duchess of Devonshire." Edited by the Duchess of Devonshire. Angle Saxon Review (June 1899):225-242.

- "Selections From the Letters of Georgiana, Duchess of Devonshire by the Duchess of Devonshire." Edited by the Duchess of Devonshire. Angle Saxon Review (September 1899):31-89.

Dod, Charles R. Charles R. Dod's Electoral Facts From 1832 to 1853 Impartially Stated. Edited by H. J. Hanham. Brighton, England: Harvester Press, 1972.

Douglas, Sylvester. Diaries of Sylvester Douglas, Lord Glenbervie. Edited by Francis Bickley. 2 vols. London: Constable, 1928.

Drinkwater, John. Charles James Fox. New York: Cosmopolitan Book Company, 1928.

Eden, Emily. Miss Eden's Letters. Edited by Violet Dickinson. London: Macmillan, 1919.

Elliot, Gilbert. The Iife and Letters of Sir Gilbert Elliot, First Earl of Minto From 1751-1806. Edited by Emma Eleanor Elliot-Murray-Kynynmound, Countess of Minto. 3 vols. London: Longmans, Green, 1874.

Ellis, Harold A. "Aristocratic Influence and Electoral Independence: Two Aspects of Whig Parliamentary Reform 1792-1832." Journal of Modern History 51 (1979):viii. 
Elofson, Warren M. "The Rockingham Whigs and the Country Tradition." Parliamentary History 8 (1989):90-115.

Epstein, Julia. The Iron Pen, Erances Burney and the Politics of Women's Writing. Madison: University of Wisconsin Press, 1989.

Erickson, Carolly. Our Tempestous Day: A History of Regency England. New York: William Morrow, 1986.

Eyck, Erich. Pitt Versus Fox: Father and Son, 1735-1806. Translated by Eric Northcott. London: G. Bell, 1950.

Feiling, Keith Grahame. Sketches in Nineteenth Century Biography. London: Longmans, Green, 1930.

Fergusson, Alexander. The Honourable Henry Erskine, Lord Advocate for Scotland with Notices of Certain of His Kinfolk and of His Time. Edinburgh: W. Blackwood, 1882 .

Fife, James Duff. Lord Fife and His Factor, Being the Correspondence of James, 2nd Lord Fife, 1729-1809. Edited by Alistair and Henrietta Tayler. London: Heinemann, 1926.

Fisher, J. R. "Issues and Influence: Two By-Elections in South Nottinghamshire in the Mid-Nineteenth Century." Historical Journal 24 (1981):155-165.

"The Tory Revival of the 1830s: An Uncontested Election in South Nottinghamshire." Midland History 6 (1981) : 95-108.

Fitzgerald, Brian. Emily Duchess of Leinster, 1731-1814: A Study of Her Life and Times. New York: Staples Press, 1949 .

Fitzgerald, Percy. The Life of George the Fourth. 2 vols. London: Tinsley, 1881.

Flexner, Eleanor. Mary Wollstonecraft: A Biography. New York: Coward, McCann \& Geoghegan, 1972.

Foord, Archibald S. His Majesty's Opposition 1714-1832. Oxford: Clarendon, 1964. 
Foot, Jesse. The Lives of Andrew Robinson Bowes and the countess of Strathmore. London: J. Bryan for Becket \& Porter, 1810.

Forrester, E. G. Northamptonshire County Elections and Electioneering 1695-1832. London: Oxford University Press, 1941.

Foster, Elizabeth. Children of the Mist: A True and Informal Account of an Eighteenth Century Scandal. New York: Macmillan, 1961.

Foster, Vere, ed. The Two Duchesses: Family Correspondence of and Relating to Georgiana Duchess of Devonshire and Elizabeth Duchess of Devonshire 1777-1859. London: Blackie, 1898 .

Fothergill, Brian. The Strawberry Hill Set, Horace Walpole and His Circle. London: Faber and Faber, 1983.

Fraser, Peter. "Party Voting in the House of Commons 1812-1827." English_Historical Review 98 $(1983): 763-784$.

Fritz, Paul, and Morton, Richard, eds. Woman in the $18 \mathrm{th}$ Century \& Other Essays. Toronto: Hakkert, 1976.

Fritz, Paul, and Williams, David, eds. City \& Society in the 18th Century. Toronto: Hakkert, 1973.

, eds. Triumph of Culture: 18 th century

Perspectives. Toronto: Hakkert, 1972.

Frow, Ruth, and Frow, Edmund, eds. Political Women 1800-1850. Introduction by Julia Swindells. London: Pluto Press, 1989.

Fryer, C. E. "The General Election of 1784." History 9 (1924):221-223.

Fyvie, John. Notable Dames and Notable Men of the Georgian Era. London: Constable, 1910.

Gash, Norman. Aristocracy and People, Britain 1815-1865. Cambridge: Harvard University Press, 1979.

Politics in the Age of Peel: A study in the Technigue of Parliamentary Representation 1830-1850. London: Longmans, Green, 1969. 
Sir Robert Reel: The Iife of Sir Robert Peel

After 1830. Totowa, NJ: Rowman and Littlefield, 1972.

George, Eric [Mrs.]. "Fox's Martyrs': The General Election of 1784." Transactions of the Royal Historical Society: ser. 4, 21 (1939):133-168.

George III, King of Great Britain. The Correspondence of King George the Third From 1760 to December 1783. Edited by Sir John Fortescue. 6 vols. London: Cass, 1967.

- The Later correspondence of George III. Edited by Arthur Aspinall. 5 vols. Cambridge, England: Cambridge University Press, 1966-1970.

Gillett, Edward. History of Grimsby. London: Oxford University Press for the University of Hull, 1970.

Gillett, Edward, and MacMahon, Kenneth A. A History of Hull. London: Oxford University Press for the University of Hull, 1980.

Ginter, Donald E. "The Financing of the Whig Party Organization 1783-1793." American Historical Review $71(1966): 421-440$.

- comp. Whig Organization in the General Election of 1790: Selected From the Blair Adams Papers. Berkeley: University of California Press, 1967.

Girouard, Mark. Life in the English country House: A Social and Architectural History. New Haven, CT: Yale University Press, 1978.

Glen, Robert. "A New Letter by Richard Brinsley Sheridan." Notes and Queries 37 (1990):11-14.

Glenbervie, Sylvester Douglas. The Diaries of Sylvester Douglas, Lord Glenbervie. Edited by Francis Beckley. London: Constable, 1928.

Golby, John. "A Great Electioneer and His Motives: The Fourth Duke of Newcastle." Historical Journal 8 (1965):201-218.

Goncourt, Edmond de, and Goncourt, Jules de. The Woman of the Eighteenth Century: Her Life From Birth to Death, Her Love, and Her Philosophy in the worlds of Salon. 
Shop, and Street. Translated by Jacques Le Clerq and Ralph Roeder. New York: Minton, Balch \& Co., 1927.

Gooder, A. Parliamentary Representation of the county of Yorkshire 1258-1832. 2 vols. The Yorkshire Archaeological Society Record Series XCI. Wakefield, Yorkshire: West Yorkshire Printing Company, 1935.

Granville, George Leveson Gower. The Life of George Leveson Gower Second Earl Granville, 1815-1891. 2 vol. 3rd ed. Edited by Edmond George Petty Fitzmaurice. London: Williams \& Norgate, 1952.

Granville, Henrietta Elizabeth Leveson Gower. Hary-o: The Letters of Lady Harriet Cavendish, 1796-1809. Edited by Sir George Leveson Gower and Iris Palmer. London: John Murray, 1940.

- Letters of Harriet, Countess of Granville, 1810-84. Edited by the Hon. F. Leveson Gower. 2 vols. London: Longmans, Green, 1894.

- A Second Self: The Letters of Harriet Granville, 1810-1845. Edited by Virginia Surtess. Salisbury, Wiltshire: Michael Russell, 1990.

Granville, Leveson Gower, Earl. Lord Granville Leveson Gower, Private Correspondence 1781-1821. Edited by Countess Castalia Granville. 2 vols. London: John Murray, 1916.

Greaves, Margaret. Regency Patron: Sir George Beaumont. London: Methuen Press, 1966.

Grego, J. History of Parliamentary Elections and Electioneering From the stuarts to oueen Victoria. London: Chatto \& Windus, 1892.

Greville, Charles Cavendish Fulke. The Greville Memoirs, 1821-1860. Edited by Roger Fulford. Revised ed. New York: Macmillan, 1963.

- The Greville Memoirs: The Journals of the Reigns of King George III and King William IV. Edited by Henry Reeve. 2 vols. New York: D. Appleton, 1886.

Grosvenor, Caroline Susan, and Beilby, Charles. The Eirst Lady Wharncliffe and Her Family $(1779-1856) .2$ vols. London: Heinemann, 1986. 
Guedalla, Philip. A Gallery. New York: Putnam, 1924. - Palmerston. New York: Putnam, 1927.

Gunn, J. A. W., ed. Factors No More: Attitudes to Party in Government and Opposition in Eighteenth Century England. Extracts From Contemporary Sources. London: Frank Cass, 1971.

Hamel, Frank. Lady Hester Lucy Stanhope: A New Iight on Her Life and Love Affairs. London: Cassell, 1913.

Hamilton, Mary. At Court and At Home From the Letters and Diaries of Mary Hamilton. Later Mrs. Dickinson 1756-1816. Edited by Elizabeth and Florence Anson. London: J. Murray, 1925.

Hannay, Prudence. "The Redoubtable Lady Holland." History Today 23 (1973): 94-104.

Harris, Frances. "The Electioneering of Sarah, Duchess of Marlborough." Parliamentary History 2 (1983):71-92.

Haslip, Joan. Lady Hester Stanhope: A Biography. London: R. Cobden Sanderson, 1934 .

Hawes, Frances. Henry Brougham. New York: St Martin's, 1958 .

Hays, Mary. An Appeal to the Men of Great Britain in Behalf of Women. 1798. Edited by Gina Luria. New York: Garland, 1974 .

Heesom, Alan J. "'Legitimate' Versus 'Illegitimate' Influences: Aristocratic Electioneering in Mid Victorian Britain." Parliamentary History 7 (1988) :282-305.

"The Sunderland By-Election September 1841." Northern History 9 (1974):62-78.

Hibbert, Christopher. George IV Prince of Wales 1762-1811. London: Longman, 1972 .

- George IV Regent and King 1811-1830. London: Allen Lane, 1973.

Hill, Bridget, comp. Eighteenth Century Women: An Anthology. London: Allen \& Unwin, 1984. 
The Republican Virago: The Life and Times of Catherian Macaulay. Historian. Oxford: Clarendon, 1992 .

- Women, Work, and sexual politics in

Eighteenth-Century England. Oxford: Basil Blackwell, 1989 .

Hilton, Boyd. "Review of 'Holland House' by Leslie Mitchell." Parliamentary History 2 (1983):251-253.

Holland, Elizabeth Vassall Fox. Elizabeth Lady Holland to Her Son 1821-1845. Edited by the Earl of Ilchester. London: John Murray, 1946.

Journal of Elizabeth, Lady Holland 1791-1811. Edited by the Earl of Ilchester. 2 vols. London: Longmans, 1908 .

Holland, Henry Richard Vassall Fox. Further Memoirs of the Whig Party During My Time 1807-1821 with Some Miscellaneous Reminisces. Edited by Lord Stavordale. New York: E. P. Dutton, 1905.

The Holland House Diaries, 1831-1840. Edited by Abraham D. Kriegel. London: Routledge, 1977.

Holland, Henry Richard Vassall Fox. Memoirs of the Whig Party During My Time. Edited by Henry Edward, Lord Holland. 2 vols. London: Longman, Brown, Green \& Longmans, 1852 .

Houston, Robert Allan. "British Society in the Eighteenth Century." Journal of British Studies 25 (1986) : $436-466$.

Hunt, William, and Poole, Reginald, eds. Political History of England. 12 vols. London: Longmans, Green, 1905. Vol 10: The History of England From the Accession of George III, to the Close of Pitt's First Administration (1760-1801), by William Hunt.

, eds. Political History of England. 12 vols. London: Longmans, 1906. Vol. 11: The House of England From Addington's Administration to the close of William IV's Reign (1801-1837), by George C. Broderick and J. K. Fotheringham.

, eds. Political History of England. 12 vols. London: Longmans, 1906. Vol 12: The House of England 
During the Reign of Victoria (1837-1901), by Sidney Low and Lloyd C. Sanders.

Hunter, Jean E. "The Eighteenth Century Englishwoman:

According to the Gentleman's Magazine." In Woman in

the 18th Century and other Essays, pp. 73-88. Edited by Paul Fritz and Richard Morton. Toronto: S. stevens, 1976.

Huxley, G. Lady Elizabeth and the Grosvenors Iife in a Whig Family, 1822-1839. London: Oxford University Press, 1965.

Ilchester, Giles Stephen Holland Fox-Strangeways, Sixth Earl of. Chronicles of Holland House, 1820-1900. London: John Murray, 1946.

Innes, Joanna. "Parliament and the Shaping of Eighteenth Century English Social Policy." Transactions of the Royal Historical Society: 5th Series 40 (1990):63-92.

Jekyl1, Joseph. Correspondence. Edited by Algernon Bourke. London: J. Murray, 1894.

Johnson, Samuel. The Letters of Samuel Johnson. Edited by R. W. Chapman. 3 vols. Oxford: Clarendon, 1952.

- The Letters of Samuel Johnsen. Edited by Bruce Redford. 5 vols. Princeton, NJ: Princeton University Press, $1992-94$.

Jones, D. J. V. "Women and Chartism." History 68 (1983): 1-21.

Judd, Gerrit P. Members of Parliament, 1734-1832. New Haven, CT: Yale University Press, 1955.

Jupp, Peter. British and Irish Elections 1784-1831. Sources for Social History. Newton Abbot: David \& Charles, 1973; New York: Barnes \& Noble, 1973.

"The Iranded Elite and Political Authority in Britain, ca. 1760-1850." Journal of British Studies $29(1990): 53-79$. 1985 .

Lord Grenville, 1759-1834. Oxford: Clarendon, 
Kanner, Barbara, ed. The Women of England From Anglo-Saxon Times to the Present: Interpretative Bibliegraphic Essays. Hamden, CT: Archon, 1979. - Women in English Social History 1800-1214: A Guide to Research. 3 vols. New York: Garland, 1987.

Kelly, Paul. "Radicalism and Public Opinion in the General Election of 1784." Bulletin of the Institute of Historical Research 45 (1972):71-88.

Keppel, Sonia. Sovereign Iady: A Iife of Elizabeth Vassal, Third Lady Holland, With Her Family. London: Hamish Hamilton, 1974

Klieneberger, H. R. Durham Elections: A History of Material Relating to Parliamentary Elections in Durham 1675-1874. Durham: G. Bailes for the University Library, 1956.

Knox, Thomas R. "Popular Politics and Provincial Radicalism: Newcastle Upon Tyne, 1769-1785." Albion 11 (1979):224-241.

Kronenberger, Louis. Kings and Desperate Men: Life in Eighteenth-Century England. New York: Knopf, 1942.

Lamb, Caroline. Glenarvon. 3 rd ed., 3 vols. London: H. Colburn, 1816; reprint ed., New York: AMS Press, 1975.

Lambert, E. "Historic Houses: Lord Melbourne's Family Home." Architectural Digest 41 (1984):134-142.

Landau, Norma. "Eighteenth Century England: Tales Historians Tell." Eighteenth Century Studies 22 $(1988-89): 209-218$.

Langford, Paul. Public Life and the Propertied Englishman 1689-1798: Ford Lectures, University of Oxford, 1920. Oxford: Clarendon, 1991.

Laprade, William Thomas. "Public Opinion and the General Election of 1784." English Historical Review 31 (1916) :224-237.

- Public opinion and Politics in the Eighteenth Century to the Fall of Walpele. New York: Macmillan, 1936; reprint ed., Westport, CT: Greenwood Press, 1971 . 
"William Pitt and the Westminster Elections." American Historical Review 18 (1913):253-274.

Lascelles, E. The Life of Charles James Fox. London: Oxford University Press, 1936; reprint ed., New York: Octagon Books, 1970.

Lawson, Philip. George Grenville: A Political Iife. Oxford: Clarendon, 1984.

- "Hanoverian Studies: The Impact of Recent Trends on Parliamentary History." Parliamentary History 7 (1988): $130-138$.

Lean, E. Tangye. The Napoleonists: A Study in Political Disaffection, $1760-1960$. London: Oxford University Press, 1970.

Lecky, William Edward Hartpole. A History of England in the Eighteenth Century. 7 vols. London: Longmans, Green, $1891-92$.

Leconfield, Maud Mary (Lyttelton) Wyndham, Baroness, ed. Three Howard Sisters: Selections From the Writings of Lady Caroline Lascelles, Jady Dover, and the countess Gower, 1825 to 1833 . Revised and completed by John Gore. London: Murray, 1955.

Lee, Elizabeth. Wives of Prime Ministers, 1844-1906. With contributions by Mrs. C. F. G. Masterman. London: Nisbet, 1918 .

Lennox, Sarah. The Iife and Letters of Iady Sarah Lennox, 1748-1826. Edited by Mary Eleanor Dawson, Countess of Ilchester, and Giles Holland Fox-Strangeways, Lord Stavordale. London: John Murray, 1902; New York: Charles Scribner's Sons, 1902.

Leveson-Gower, Frederick. "Did Byron Write 'Werner'?" Nineteenth Century 46 (1899):243-250.

Lewis, D. B. Wyndham. Four Favourites. New York: Longmans, Green, 1949 .

Lewis, Judith S. "Political Behavior of Elite Women in England 1774-1832." Consortium of Revolutionary Europe, 1750-1850 Proceedings (1983):242-270. 
Lieven, Dorothea. The Private Jetters of Princess Lieven to Prince Metternich, 1820-1926. Edited by Peter Quennell. London: John Murray, 1937.

Lister, Anne. I Know My Own Heart: The Diaries of Anne Lister 1791-1840. Edited by Helena Whitbread. New York: New York University Press, 1988.

- Miss Iister of Shibden Hal1: Selected Ietters, 1800-1840. Edited by Muriel M. Green. Sussex: The Book Guild, 1992 .

Iondon Chronicle, 3-6, 15-17 April; 15-18, 18-20 May 1784 .

Lowe, William C. "The House of Lords, Party, and Public Opinion: Opposition Use of Protest, 1760-1832."

Albion 11 (1979):143-156.

"Peers and Printers: The Beginning of Sustained Press Coverage of the House of Lords in the 1770s." Parliamentary History 7 (1988):241-256.

Lyttelton, Thomas. Chronicles of the Eighteenth century, Founded on the correspondence of Sir Thomas Iyttelton and His Family. Edited by Maud Wyndham. 2 vols. London: Hodder \& Stroughton, 1924.

Lyttelton, Sarah Spencer, Lady. Correspondence of Sarah Spencer, Lady Lyttelton 1787-1870. Edited by Maud Mary Wyndham. London: John Murray, 1912.

Mack, Phyllis. "The History of Women in Early Modern Britain: A Review Article." Comparative studies in Society and History 28 (1986):715-722.

Maclean, John. Historical and Genealogical Memoir of the Family of Poyntz. Exeter: William Pollard, 1886.

Mandler, Peter. Aristocratic Government in the Age of Reform whigs and Liberals, 1830-1852. Oxford: Clarendon, 1990 .

Martineau, Harriet. Biographical Sketches. New York: Leypold \& Holt, 1869.

Masters, Brian. The Dukes: The Origins, Ennoblement and History of 26 Families. London: Blond \& Briggs, 1975. Hamilton, 1981 . 
Mayne, Ethel Colburn. A Regency Chapter: Lady Bessborough and Her Friendships. London: Macmillan, 1939.

McAdams, Donald R. "Electioneering Techniques in Populous Constituencies, 1784-96." Studies in Burke and His Time 14 (1972):23-53.

McCord, Norman. "Economic and Social Developments Between 1780 and 1830." In Whig Ascendancy Colloquies on Hanoverian England, pp. 151-169. Edited by John Ashton Cannon. London: Edward Arnold, 1981.

. "Gateshead Politics in the Age of Reform." Northern History 4 (1969):167-183.

McGowen, Randall E., and Arnstein, Walter L. "The Mid-Victorians and the Two-Party System." Albion 11 (1979):224-241.

McLeod, Kirsty. The Wives of Downing Street. London: Collins, 1976

McQuiston, Julian R. "The Lonsdale Connection and Its Defender, William, Viscount Lowther 1818-1830." Northern History 11 (1976):143-179.

1820." Sussex Aristocrats and the County Election of

Melbourne, William Lamb. Lord Melbourne's Papers. Edited by Lloyd C. Sanders. Preface by the Earl of Cowper. 2nd ed. London: Longmans, Green, 1890; reprint ed., New York: Kraus Reprint Co., 1971.

. Memoirs of William Lamb, Second Viscount Melbourne. Edited by William McCullagh Torrens. London: Macmillan, 1878; reprint ed., London: Ward, Lock, 1890 .

Menzies, Sutherland. Political Women. 2 vols. 2nd ed. Port Washington, NY: Kennikat Press, 1970.

Mikhail, E. H., ed. Sheridan: Interviews and Recollections. New York: St. Martins, 1989.

Mingay, G. E. English Landed Society in the Eighteenth

century. London: Routledge \& Paul, 1963. 
Minney, Rubeigh James. No, 10 Downing street: A House in Histery. Boston: Little Brown, 1963.

Mitchell, Leslie. Holland House. London: Gerald Duckworth, 1980 .

- Charles James Fox and the Disintegration of the Whig Party, 782-1794. London: Oxford University Press, 1971.

Money, John. "Birmingham and the West Midlands, 1760-1793: Politics and Regional Identity in the English Provinces in the Later Eighteenth Century." Midland History 1 (1971): 1-19.

"Taverns, Coffee Houses and Clubs: Local Politics and Popular Articulacy in the Birmingham Area, in the Age of the American Revolution." Historical Journal 14 (1971): $15-47$.

Montagu, Mary Wortley. The Complete Letters of Lady Mary Wortley Montagu. Edited by Peter Halsband. 3 vols. Oxford: Clarendon, 1967.

Moore, D. C. "Social Structure, Political Structure, and Public Opinion in Mid-Victorian England." In Ideas and Institutions of Victorian Britain, pp. 20-57. Edited by Robert Robson. New York: Barnes \& Noble, 1967 .

- The Letters of Thomas Moore. Edited by Wilfred S. Dowden. 2 vols. Oxford: Clarendon, 1964.

Moore, Thomas. Tom Moore's Diary. Selected ed. Edited by J. B. Priestley. Cambridge, England: Cambridge University Press, 1925.

More, Hannah. Memoirs of the Life and Correspondence of Mrs. Hannah More. Edited by William Roberts. 2 vols. New York: Harper, 1845.

Morley, Frank. Literary Britain: A Guide to Its Writers and Landmarks. New York: Harper \& Row, 1890.

Morning Post, 13, 14, 19, 20, 24, 28 April; 1, 3, 4, 15, 17 May 1784 .

Morris, R. J. "Voluntary Societies and British Urban Elites, 1780-1850: An Analysis." Historical Journal 26 (1983): 95-118. 
Morwood, James. The Life and Works of Richard Brinsley Sheridan. Edinburgh: Scottish Academic Press, 1985.

Mottram, R. H. "Town Life of London." In Early Victorian England, 1830-1865, pp. 153-224. Edited by G. M. Young. 2 vols. London: Oxford University Press, 1934; reprint ed., London: Oxford University Press, 1951.

Namier, Lewis B. Crossroads of Power: Essays on Eighteenth Century England. New York: Macmillan, 1962.

. Personalities and Powers. London: Hamish Hamilton, 1955.

- The structure of Politics at the Accession of George III. Reprint of 2 nd ed. 1st ed. in 2 vols. London: Macmillan, 1929; reprint eds., London: Macmillan, 1963; New York: St. Martin's Press, 1963.

Namier, Lewis B., Sir, and Brooke, John, eds. The House of Commons, 1754-1790. 3 vols. New York: Secker and Warburg for the History of Parliament Trust, 1964.

New, Chester W. Life of Henry Brougham to 1830. Oxford: Clarendon, 1961.

Newbould, Ian. "Whiggery and the Growth of Party 1830-1841: Organization and the Challenge of Reform." Parliamentary History 4 (1985):137-156.

- Whiggery and Reform 1830-41: The politics of Government. Stanford, CA: Stanford University Press, 1990 .

Newman, Bertram. Lord Melbourne. London: Macmillan \& Co., 1930 .

Nicholas, Herbert George. To the Hustings: Election Scenes From English Fiction. London: Cassell, 1956.

Northumberland, Elizabeth Seymour Percy, Duchess of. Diaries of a Duchess, 1752-1774. Edited by James Greig. New York: Doran, 1927.

Nossiter, Thomas Johnson. Influence, Opinion and Political Idioms in Reformed England: Case Studies From the 
North-East, 1832-1874. New York: Barnes \& Noble; Hassocks, Sussex: Harvester Press, 1975.

Notes and Queries. Series 2, 12 (November 1861):394.

Notes and Queries. Series 4, 11 (February 1873) :155.

Notes and Oueries. Series 4, 11 (March 1873):227.

O'Gorman, Frank. "Campaign Rituals and Ceremonies: The Social Meaning of Elections in England 1780-1860." Past \& Present 135 (1992): 79-115.

"Electoral Deference in 'Unreformed' England:

1760-1832." Journal of Modern History 56 (1984): 391-429.

- Emergence of the Two Party System, 1760-1832. London: E. Arnold, 1982; New York: Holmes \& Meier, 1982 .

"Party in the Later Eighteenth Century." In Whig Ascendancy colloquies on Hanoverian England, pp. 77-99. Edited by John Ashton Cannon. London: Edward Arnold, 1981 .

- "Party Politics in the Early Nineteenth Century (1812-1832)." English Historical Review 102 $(1987): 63-88$.

- The Rise of Party in England: The Rockingham Whigs 1760-1782. London: Allen \& Unwin, 1975.

"The Unreformed Electorate of Hanoverian England: The Mid Eighteenth Century to the Reform Act of 1832." Social History 11 (1986):33-52.

- Voters, Patrons, and Parties: The Unreformed Electoral System of Hanoverian England, 1734-1832. Oxford: Clarendon Press, 1989.

- The Whig Party and the French Revolution. London: Macmillan, 1967; New York: St. Martin's Press, 1967.

O'Malley, Ida Beatrice. Women in Subjection: A Study of the Lives of Englishwomen Before 1832. London: Duckworth, 1933.

Olien, Diane Davids. Morpeth: A Victorian Public Career. Washington, DC: University Press of America, 1983. 
Osbaldeston, George. Squire Osbaldeston: His Autobiography. Edited by Edward William Cuming. London: John Lane, 1926; New York: C. Scribners, 1926.

Osborn, Sarah Byng. Letters of Sarah Byng Osborn. 1721-1773. Edited by John McClelland. Palo Alto, CA: Stanford University Press, 1930.

Owen, J. B. "Political Patronage in Eighteenth Century England." In Triumph of Culture: 18th Century Perspectives, pp. 369-387. Edited by Paul Fritz and David Williams. Toronto: Hakkert, 1972.

Palmer, Iris Irma Leveson-Gower. Face Without a Frown: Georgiana, Duchess of Devonshire. London: F. Muller, Ltd., 1944 .

Palmerston, Emily Cowper. Letters of Lady Palmerston Selected and Edited from the Originals at Broadlands and Elsewhere. Edited by Tresham Lever. London: J. Murray, 1957.

Palmerston, Third Viscount. Letters of the Third Viscount Palmerston to Laurence and Elizabeth Sulivan 1804-1863. Edited by Kenneth Bourne. Camden Miscellany 4th Series, vol. 23. London: Royal Historical Society, 1979.

Pares, Richard, and Taylor, A. J. P., eds. Essays Presented to Sir Lewis Namier. London: Macmillan, 1956.

Parker, R. A. C. Coke of Norfolk: A Financial and Agricultural Study 1707-1842. Oxford: Clarendon, 1975 .

Parry, J. P. "Constituencies, Elections and Members of Parliament, 1790-1820." Parliamentary History 7 (1988): $147-160$.

Paston, George. Social Caricature in the Eighteenth Century. London: Methuen \& Co., 1905; reprint ed., New York: Benjamin Blom, 1968.

Patterson, Catherine F. "Leicester and Lord Huntingdon: Urban Patronage in Early Modern England." Midland History 46 (1991):45-62.

Pearson, John. The Serpent \& the Stag. 1st American ed. New York: Holt, Rinehart \& Winston, 1983. 
Peel, Georgiana Adelaide. Recollections of Lady Georgiana Peel. Edited by Ethel Peel. London: J. Lane, 1920.

Pembroke, Henry Herbert. Pembroke Papers 1780-1794: Letters and Diaries of Henry, 10 th Earl of Pembroke and His Circle. Edited by Lord Herbert. London: Cape, 1950.

Perkin, Harold. The Origins of Modern English Society 1780-1880. London: Routledge \& Kegan Paul, 1969; Toronto: University of Toronto Press, 1969.

Perry, T. W. Public Opinion, Propaganda, and Politics in Eighteenth Century England: A Study of the Jew Bill of 1753. Cambridge: Harvard University Press, 1962.

Peters, Margot. "Biographies of Women." Biography 2 (1979) :201-217.

Phillips, John A. Electoral Behavior in Unreformed England. Princeton, NJ: Princeton University Press, 1982.

- The Great Reform Bill in the Borough: English Electoral Behavior 1818-1841. Oxford: Clarendon, 1992 .

\footnotetext{
"Popular Politics in Unreformed England." Journal of Modern History 52 (1980):599-625.

"Structure of Electoral Politics in Unreformed England." Journal of British Studies 19

(1979): $76-100$.
}

Phillips, Norman Charles. Yorkshire and English National Politics, 1783-1784. Christchurch, New Zealand: University of Canterbury Press, 1961.

Pinney, Thomas, ed. Letters of Thomas Babington Macaulay. 6 vols. Vol. 2: March 1831-December 1833. London: Cambridge University Press, 1974-81.

Piozzi, Hester Lynch Salusbury Thrale. Autobiography: Letters and Literary Remains of Mrs. Piozzi (Thrale). Edited by A. Hayward. 2 vols. 2nd ed. London: Longman, 1861 .

Lyn piozi 1784-1821 Edited by vols. Newark, NJ: University of Delaware Presses, 1989 . 
- The Thrales of Streatham Park 1766-1778: Journal ef an Eighteenth Century Family. Edited by Mary Hyde. Cambridge: Harvard University Press, 1976, 1977.

- Thraliana: The Diary of Mrs. Hester Lynch Thrale (Later Mrs. Piozzi), 1776-1809. Edited by Katherine C. Balderston. 2 vols. Oxford: The Clarendon Press, 1942 .

Plumb, John Harold. "Political Man." In Man Versus Society in Eighteenth-Century Britain: Six Points of View, pp. 1-21. Edited by James L. Clifford. Cambridge, England: Cambridge University Press, 1968.

- The First Eour Georges. London: Batsford, 1956. - Men and centuries. Boston: Houghton, 1963.

Pocock, J. G. A. "The Classical Theory of Deference." American Historical Review 81 (1976):516-523.

Porritt, Edward. The Unreformed House of Commons, Parliamentary Representation Before 1832. 2 vols. Reprints of Economic Classics. London: Cambridge University Press, 1903; reprint ed., New York: Augustus M. Kelley, 1963 .

Porter, Roy. English Society in the Eighteenth Century. London: Harmondsworth, 1982; Middlesex, NY: Penguin, 1982 .

"English Society in the Eighteenth Century Revisited." In British Politics and Society From Walpole to Pitt 1742-1789, pp. 29-52. Edited by Jeremy M. Black. Basingstoke, Hampshire: Macmillan, 1990.

Prest, John. Lord John Russe11. London: Macmillan, 1972.

Quinn, J. F. "York Elections in the Age of Walpole." Northern History 22 (1986):175-197.

Rae, William Fraser. Sheridan, A Biography. 2 vols. London: Richard Bentley, 1896.

Wilkes, Sheridan, and Fox: The opposition Under George III. London: W. Ibister, 1874. 
Raikes, Thomas. A Portion of the Journal kept by Thomas Raikes from 1831-1847. 4 vols. London: Longmans, Green, 1856-57.

Redman, Alvin. The House of Hanover. 1st American ed. New York: Coward-McCann, 1961.

Reid, Loren Dudley. Charles James Fox: A Man for the People. Columbia: University of Missouri Press, 1969.

Rendall, Jane, ed. Equal or Different: Women's Politics 1800-1914. Oxford: Basil Blackwell, 1987.

"Review of 'The Journals of Caroline Fox.'" Quarterly Review 153 (1882):530-551.

"Review of 'Life and Letters of Sir Charles Lyell.'" Quarterly Review 153 \#305 (1882):96-131.

"Review of 'Life, Letters, and Journals of Sir Charles Lyell,' edited by Mrs. Lyell." Quarterly Review 153 (\#305 1882):96-131.

"Review of 'Memories of old Friends: Being Extracts from the Journals and Letters of Caroline Fox' edited by Horace M. Pym." Quarterly Review 153 (1882):530-551.

"Review of 'Record of a Girlhood' by Frances Ann Kemble." Quarterly Review 154 (1883):83-123.

Richards, Eric. "The Social and Electoral Influence of the Trentham Interest, 1800-1860." Midland History 3 (1975) :117-148.

Ridley, Cecilia. Cecilia: The Life and Letters of Cecilia Ridley, 1819-1845. Edited by Viscountess Ursula Ridley. London: R. Hart-Davis, 1958.

Roberts, Michael. The Whig Party 1807-1812. London: Macmillan, 1939, reprint ed., New York: Barnes \& Noble, 1965.

Robinson, John. Parliamentary Papers of John Robinson 1774-1784. Edited by William Thomas Laprade. Camden Miscellany 3 rd Series, vol. 33. London: The Royal Historical Society, 1922.

Robinson, Mary Darby. Mrs. Mary Robinson, Written by Herself. With the Lives of the Duchesses of Gordon and Devonshire by Grace and Philip Wharton. Imperial 
ed. Beaux \& Belles of England Series. London: The Grolier Society, n.d.

Robson, Robert, ed. Ideas and Institutions of Victorian Britain. New York: Barnes \& Noble, 1967.

Rogers, Katherine M., ed. Before Their Time: Six Women Writers of the Eighteenth Century. New York: Frederick Ungar, 1979.

- Feminism in Eighteenth-Century England. Urbana: University of Illinois Press, 1982.

Rogers, Nicholas. "Aristocratic Clientage, Trade and Independency Popular Politics in Pre-Radical Westminster." Past \& Present 61 (1973):70-106.

Whigs and Cities: Popular Politics in the Age of Walpole and Pitt. Oxford: Clarendon, 1989.

Roscoe, Edward Stanley. The English Scene in the Eighteenth Century. London: Constable, 1912.

Ross, J. F. S. "Women of Parliamentary Elections." British Journal of Sociology 4 (1953):14-24.

Roundell, Julia Anne Elizabeth Tollemache (Mrs. Charles). Lady Hester Stanhope. London: John Murray, 1909.

Rowe, Violet. "The Hertford Borough Bill of 1834." Parliamentary History 11 (1992):88-107.

Rude, George, ed. The Eighteenth Century. Sources in Western Civilization Series, no. 8. London: Free Press, 1965.

- Hanoverian London 1714-1808. Berkeley:

University of California Press, 1971.

. "The Middlesex Elections of 1768-1769." English Historical Review 75 (1960):601-617.

Russell, John. The Early Correspondence of Lord John Russell, 1805-1840. Edited by Rollo [Francis Albert] Russell. 2 vols. London: T. Fisher Unwin, 1913.

The Later Correspondence of Lord John Russell, 1840-1878. Edited by G. P. Gooch. 2 vols. London: Longmans, Green, 1925. 
Recollections and Suggestions 1813-1873. Boston: Roberts Brothers, 1875.

Sack, James J. "The House of Lords and Parliamentary Patronage in Great Britain, 1802-1832." Historical Journal 23 (1980):913-937.

"The Memory of Burke and the Memory of Pitt: English Conservatism Confronts Its Past 1806-1829." Historical Journal 30 (1987):623-640.

Sadleir, Michael T. H. The Political Career of Richard Brinsley Sheridan. Stanhope Essay for 1912. Oxford: Blackwell, 1912 .

Sanders, Lloyd C. Holland House Circle. New York: G. P. Putnam's Sons, 1908.

Sanders, Valerie. The Private Iives of Victorian women: Autobiography in Nineteenth-Century England. New York: St. Martin's Press, 1989.

Sapiro, Virginia. A Vindication of Political Virtue: The political Theory of Mary Wollstonecraft. Chicago: University of Chicago Press, 1992.

Schwartz, Richard B. Daily Life in Johnson's London. Madison: University of Wisconsin Press, 1983.

Schwerer, Lois G. "Seventeenth-Century Women: Engraved in Stone?" Albion 6 (1984):389-403.

Selley, W. T. England in the Eighteenth Century. 2nd ed. London: Adam \& Charles Black, 1949.

Seymour, Charles. Electoral Reform in England and Wales: The Development of the Parliamentary Franchise, 1832-1885. New Introduction by Michael Hurst. New Haven, CT: Yale University Press, 1915; reprint ed., Hamden, CT: Archon Books, 1970.

Shelley, Frances. The Diary of Frances, Lady Shelley. Edited by Richard Edgecumbe. 3 vols. London: J. Murray, 1912-13.

Sheridan, Elizabeth. Betsy Sheridan's Journal. Edited by William LeFanu. New Brunswick, NJ: Rutgers University Press, 1960. 
Sheridan, Richard Brinsley. The Letters of Richard Brinsley Sheridan. Edited by Cecil Price. 3 vols. Oxford: Clarendon, 1966.

Sherson, Errol Henry Stuart. The Lively Lady Townshend and Her Friends: An Effort to Set Forth the Doings and Surroundings of a Typical Lady of ouality of the Eighteenth Century. London: William Heinemann, 1926.

Sichel, Walter Sydney. Sheridan. From New and Original Material. Including a Manuscript Diary by Georgiana, Duchess of Devonshire. 2 vols. London: Constable, 1909 .

Smith, Catherine. "Image and Reality: Two Nottinghamshire Market Towns in Late Georgian England." Midland History 47 (1992):59-74.

Smith, E. Anthony. "Bribery and Disenfranchisement: Wallingford Elections, 1820-1832." English Historical Review 75 (1960):618-630.

- "Earl Fitzwilliam and Malton: A Proprietary Borough in the Early Nineteenth Century." English Historical Review 80 (1965):51-69.

. "The Election Agent in English Politics, 1784-1832." English Historical Review 84 (1969) :12-35.

- Lord Grey, 1764-1845. Oxford: Clarendon, 1960. - Whig Principles and Party Politics: Earl

Fitzwilliam and the Whig Party, 1748-1823.

Manchester, England: Manchester University Press, 1975; Totowa, NJ: Rowman and Littlefield, 1975.

"The Yorkshire Elections of 1806 and 1807: A Study in Electoral Management." Northern History 9 (1974) :62-90.

Smith, Robert Worthington. "Political Organization and Canvassing: Yorkshire Elections Before the Reform Bill." American Historical Review 74 (1969) : 1538-1560.

Smith, Verena, ed. The Town Book of Lewes, 1702-1837. Sussex Record Society, vol. 69. Lewes, Sussex: Sussex Record Society, 1973. 
Soulbury, Herwald Ramsbotham, Lord. "Women of Influence, 1750-1800". Quarterly Review 297 (1959):400-407.

Southgate, Donald. "The Mest English Minister..."The Policies of Palmerston. London: Macmillan, 1966.

- The Passing of the Whigs, 1832-1886. London: Macmillan, 1962 .

Speck, William A. "English Politics and Society in the Eighteenth Century" [Review Article]. Historian 12 $(1986): 359-379$.

\section{"Northumberland Elections in the Eighteenth Century." Northern History 28 (1992):164-177.}

Spring, Eileen. "The Heiress-at-Law." Law \& History Review 8 (1990): 273-296.

Stacey, Margaret, and Price, Marion. Women, Power and politics. London: Tavistock Publications, 1981.

Stebbins, Lucy Poate. Iondon Ladies: True Tales of the 18 th Century. New York: Columbia University Press, 1952.

Stenton, Doris Mary. The English Woman in Histery. London: George Allen, 1957.

Stephen, Leslie, and Lee, Sidney, eds., Dictionary of National Biography. 22 vols. London: Oxford University Press, 1917; reprint ed., London: Oxford University Press, 1949-50.

Stirling, A. M. W. Coke of Norfolk and His Friends: The Life of Thomas William coke, The First Earl of Leicester of Holkham. 2 vols. London: John Lane The Bodley Head, 1908.

Stokes, Hugh. The Devonshire House Circle. London: H. Jenkins, 1917 .

Stone, Lawrence. An open Elite? 1540-1880. Oxford: Clarendon, 1984 .

Strickland, Margot. The Byron Women. New York: St. Martin's, 1974 .

Stuart, Dorothy Margaret. Dearest Bess: The Life and Times of Lady Elizabeth Foster, Afterwards Duchess of 
Devonshire, From Her Unpublished Journals and Correspondence. London: Methuen, 1955.

Surtees, Robert. The History and Antiguities of the county Palatine of Durham. 4 vols. Classical County Histories Series. Durham, England: EP Publishing in collaboration with Durham County Library, 1972.

Sutherland, George Granville Leveson Gower, 2nd Duke of. Stafford House Letters. Edited by Ronald Charles, Gower. London: K. Paul, 1891.

Sutherland, Lucy. "The City of London in Eighteenth Century Politics." In Essays Presented to Sir Lewis Namier, pp. 49-74. Edited by Richard Pares and A. J. P. Taylor. London: Macmillan, 1956.

Sydney, William Connor. England and the English in the Eighteenth Century: Chapters in the Social History of the Time. 2 vols. 2nd ed. London: Ward \& Downey, 1892 .

Symonds, George Paston. Iittle Memoirs of the Nineteenth Century. London: Grant Richards, 1902; New York: Dutton, 1902 .

Taylor, A. J. P. "Lord Palmerston." History Today 41 (1990): $15-20$.

Thane, Pat. "Women, Sex and Politics, 1860-1918." Parliamentary History 8 (1989):13-15.

Thomas, P. D. G. The House of Commons in the Eighteenth Century. Oxford: Clarendon, 1971.

Thomis, Malcolm I. Politics and Society in Nottingham 1785-1835. New York: Augustus M. Kelley, 1969.

Thomis, Malcolm I., and Grimmett, Jennifer. Women in Protest 1800-1850. New York: St. Martin's Press, 1982 .

Thompson, Dorothy. "Women, Work and Politics in Nineteenth Century England: The Problem of Authority." In Equal or Different: Women's Politics 1800-1914, pp. 57-81. Edited by Jane Rendall. Oxford: Basil Blackwell, 1987 . 
Thorne, R. G. House of Commons, 1790-1820. 5 vols. London: Secker \& Warburg for the History of Parliament Trust, 1986 .

Ticknor, Frederick William. Women in English Economic History. New York: E. P. Dutton \& Co., 1923.

Tierney, Helen, ed. Women's Studies Encyclopedia. 3 vols. New York: Greenwood Press, 1989.

Todd, Janet, ed. Dictionary of British and American Women Writers 1660-1800. Towtowa, NJ: Rowman \& Allenheld, 1985.

Torrington, John Byng. The Torrington Diaries 1781-1794. Edited by $C$. Bruyn Andrews. 4 vols. New York: Henry Holt, 1935-8.

Trainor, Richard. "Peers on and Industrial Frontier: The Earls of Dartmouth and of Dudley in the Black Country, c. 1810-1914." In Patricians, Power and Politics in Nineteenth-Century Towns, pp. 70-132. Edited by David Cannadine. Leicester University Press, 1982; New York: St. Martin's Press, 1982.

Trevelyan, George Macaulay. Illustrated English Social History. 4 vols. Vol. 3 : The Eighteenth Century. London: Longmans, Green, 1951.

Lord Grey of the Reform Bill: The Life of Charles, Second Earl Grey. 2nd ed. London: Longmans, Green, 1929 .

Turberville, Arthur Stanley. English Men and Manners in the Eighteenth Century. Oxford: Clarendon, 1926.

, ed. Johnson's England: An Account of the life and Manners of His Age. Oxford: Clarendon, 1933.

Uglow, Jenifer $S$. , ed. The Continuum Dictionary of Women's Biography. New expanded ed. New York: Continuum, 1989 .

Van Thal, Herbert, ed. The Prime Ministers. Introduction by G. W. Jones. London: George Allen \& Unwin, 1974.

Verney, Margaret Maria Williams-Hay, Lady, ed. Verney Letters of the Eighteenth century From the MSS. at Claydon House. 2 vols. London: E. Benn, 1930. 
Villiers, Marjorie. The Grand Whiggery. London: John Murray, 1939.

Von Den Steinen. "The Discovery of Women in EighteenthCentury English Political Life." In The Women of England From Anglo-Saxon Times to the Present: Interpretative Bibliographic Essays, pp. 229-252. Edited by barbara Kanner. Hamden, CT: Archon Books, 1979 .

Von den Steinen, Karl. "The Fabric of Interest in the County: The Buckinghamshire Election of 1784." Albion 4 (1972):206-218.

Walpole, Horace. Horace Walpole and His World Selected Passages From His Letters. Edited by L. B. Seeley. 4 th ed. London: Seeley \& Co, 1982.

. Horace Walpole's Correspondence. Edited by W. S. Lewis and Joseph W. Reed. 49 vols. New Haven, CT: Yale University Press, 1973.

Wark, Robert R. Meet the Ladies: Personalities in Huntington Portraits. San Marino, CA: Huntington Library, 1972 .

Wasson, Ellis Archer. "The Great Whigs and Parliamentary Reform, 1809-1830." Journal of British Studies 24 (1985) : 434-464.

Watson, J. Stephen. The Reign of George III, 1760-1815. Oxford: Clarendon, 1960.

Watson, Jennifer C. "Romney's Portrait of Lady Elizabeth Foster." Burlington Magazine 131 (1989):770-772.

West, Jane. Letters to a Young Lady. 3 vols. New York: 0 . Penniman, 1806; reprint ed., New York: Garland, 1974.

Wharton, Grace, and Wharton, Phillip. The oueens of Society. 2 vols. Philadelphia: Porter \& Coates, 1861 .

Wheeler, Ethel Rolt. Famous Blue-Stockings. London: Methuen, 1910.

White, Reginald James. Life in Regency England. Edited by Peter Quennell. English Life Series. London: B. T. Batsford, 1963. 
White, T. H. The Age of Scandal: An Excursion Through a Minor Period. New York: G. P. Putnam's Sons, 1950.

Willcox, William B. The Age of Aristocracy, 1688-1830. 2nd ed. Lexington, MA: D. C. Heath, 1971.

Williams, E. Neville. The Eighteenth Century Constitution, 1688-1815. Cambridge, England: Cambridge University Press, 1965.

Williams, Raymond. Culture and Society, 1780-1950. New York: Columbia University Press, 1958.

Wilson, Harriette. The Game of Hearts, Harriette Wilson's Memoirs. Edited by Lesley Blanch. New York: Simon \& Schuster, 1955.

Wilson, Kathleen. "Empire, Trade and Popular Politics in Mid-Hanoverian Britain: The Case of Admiral Vernon." Past \& Present 120 (1988):74-109.

Windham, William. The Diary of the Right Hon. William Windham 1784-1810. Edited by Cecilia Anne Baring. London: Longmans, 1866.

Winstanley, Denys Arthur. Lord Chatham and the Whig opposition. Cambridge, England: Cambridge University Press, 1912 .

Wraxall, Nathaniel w. Posthumous Memoirs of His own Time. Philadelphia: Carey Lea \& Blanchard, 1836.

Wright, D. G. "A Radical Borough: Parliamentary Politics in Bradford, 1832-41." Northern History 4 (1969) : 132-166.

Zegger, Robert E. John Cam Hobhouse: A Political Iife, 1812-1852. Columbia: University of Missouri Press, 1973 .

Ziegler, Philip. Melbourne: A Biography of William Lamb, Second Viscount Melbourne. London: Collins, 1976. 
APPENDIX A

BIOGRAPHICAL NOTES

The following names occur in the text of this thesis. I used the following codes:

Aspinall Iater Aspinall Arthur The Later Correspondence of George III 1966-1970; DBH Dictionary of British History; EBW Encyclopedia of British Women; Holland House Diaries ed. Kriegel 1977; Horace Walpole Correspondence ed. by Lewis; Irl of Mrs. A. Journal of Mrs. Arbuthnot 1950;

Lady Holland to Her Son Holland, Elizabeth Elizabeth Lady Holland To her Son 1821-1845 1946; N\&B Namier, Lewis B and John Brooke House of Commons, 1754-1790 1964; Second Self Granville, Henrietta A Second Self: The Letters of Harriet Granville, 1810-1845 1990; Thorne Thorne, R. G. House of Commons, 1790-1820 1986; Uglow Uglow, Jennifer The Continuum Dictionary of Women's Biography 1989. Entries without codes are from the Dictionary of National Biography.

Abercromby, Mary Anne (d. 1821) Bns s.j.

m. Gen. Ralph Abercromby (1734-1801), a relative of the Dundas family, mo. of James, Ist Id Dunfermline, suc. by son George Ralph, MP as Lord Abercromby of Tullibody.

Controlled borough of Clackmannanshire 1802-1821.

Aberdeen SEE Gordon

\section{A'Court, Janet Brown}

da. of Col. Robert Brown, sis. of Robiniana, Cts of Peterboro, m. 1768 Pierce Ashe A'Court (1701-68) MP and holder of the majority of the burgages upon the death of his mother, Elizabeth Ashe, A'Court Newcastle supporter.

Pierce gave his wife Janet, his burgages for her life, then to his nephew, William (1708-1781). Janet complained so he changed his will leaving all burgages to her outright and ordered that they be sold for her. He died three months after making this new will. His nephew William instituted 
legal action. But Janet inherited and sold the burgages at Heytesbury to the Duke of Marlborough for 14,000 [N\&B].

A'Court, William (1779-1860) lst Bn Heytesbury

s. of William Pierce Ashe A'Court, MP for Aylesbury by his 2nd wife Letitia, da. of Henry Wyndham, m. 1808 Maria Rebecca, da. of Henry William Bouverie, s. of E. of Radnor, Is William Henry Ashe A'Court, $3 \mathrm{rd} \mathrm{Bn}$ and $1 \mathrm{da}$.

Amb. to Portugal, Russia. Ld. Lt of Ireland, Gov. of Isle of Wight.

\section{Adair, Angelique Gabrielle}

da. of Marquis d' Hazencourt, m. Robert Adair (17631855), diplomat, close friend of Fox and the Hollands, former mistress to Andriossy, Napoleon's minister.

Lady Holland's son, Henry, was an attache with Robert Adair in Brussels.

Addington, Henry (1754-1844) 1st Vct Sidmouth

m. (1) 1781 Ursula Mary (d. 1811), da. of Leonard Hammond, m. (2) Mary Anne, (d. 1842), da. of Lord Stowell and widow of Ld T. Townshend.

Tory PM 1801-4, close friend of Pitt, enacted repressive press measures stemming from the Peterloo Massacre and treated the Luddites harshly [DBH].

Adhemar Jean-Balthazar d' Azemar de Montfalcon (1731-1791)

m. 1772 as her 2nd husband Gabrielle-Pauline Bouthillier (d. 1810$)$, relative of Mde. du Deffand.

French Ambassador to Britain 1783-1787 [Aspinall Later vol. 5, p. 145 note 207].

Albemarle, Lord SEE Keppel

Ancaster SEE Bertie

Andover, Lady (fl 1779)

mo. of Henry, 12th Earl of Suffolk, aunt of Walter Sneyd.

she controlled the seat of Castle Rising, Norfolk, a freeman pocket borough shared by the walpole and Howard families [Cannon Aristocratic Century p. 110].

Anglesey, Lord SEE Paget

Arbuthnot, Harriet Fane (1793-1834) diarist, extreme Tory da. of Henry Fane, s. of Thomas the 8th E. of Westmoreland and Anne, da. of Edward Buckley Batson, banker, distant relation to $D$. of Wellington, cousin to Sally Jersey, m. 1814 Charles Arbuthnot (1767-1856) as his 2nd wife. He was MP, Sect to the Treasury 1809-1823, no issue. 
Her Journal was "obsessed with politics" and she was a political animal through and through" and she had a "sharper mind" than her husband's.

\section{Ashley SEE Cooper}

\section{Bankes, William John (d. 1855)}

e. s. of Henry Bankes (d. 1835) and Frances, da. of William Woodley, Gov. of Leeward Islands, did not marry. anti-reformer, traveller in the East, close friend of Hobhouse and Byron, Mrs. Arbuthnot canvassed in Dorset for him. [Jrl of Mrs. A. vol. 1 p. 196].

Barnard, Anne Lady (1750-1825) poet, literary salonist da. of James Lindsay, $E$. of Balcarres in Fifeshire, $m$. 1793 Andrew Barnard (d. 1807), s. of Bishop of Limerick, Col. Sect. in So. Africa.

Close friend of Henry Dundas who appointed her husband to post, literary salon with Burke, Sheridan, Prince of Wales, most famous for her poem "Auld Robin Grey" [Canning Letter Journal p. 188, n. 375].

Barnes SEE Cochrane

Basset, Frances (d. 1855), Bns Bassett

da. of Francis Basset, Baron de Dunstanville (1757-1835)

a supporter of Lord North, cr Baron in 1796 by Pitt, MP

Penryn and Frances Susannah Coxe (d. 1823), da. of John Hippesley Coxe, at her father's death she became Baroness Bassett of stratton.

Bath SEE Pultney

Bathhurst, Georgiana (1761-1841), Cts Bathhurst

da. of Lord George Henry Lennox, m. 1789 Henry, Lord Apsley, and 3rd Earl Bathhurst Tory Foreign Secretary 1809, against the Reform Bill, supporter of the slave trade. [IIr] of Mrs. A vol. 1, p. 79, n. 1].

Beauchamp, Lady SEE Seymour

Beauclerk, Lady Diana (1734-1808)

da. of Charles Spencer, 2nd D. of Marlborough, sis. of Ly Betty Spencer, Cts of Pembroke, m. (1) 1757 2nd Ld Bolingbroke (div. 1768), m. (2) 1768 Topham Beauclerk (d. 1780), $3 \mathrm{ch}$.

amateur artist, illustrator of $\mathrm{H}$. Walpole's gothic books, Lady in Waiting to Queen Charlotte 1761-68.

Beaulieu, Lady SEE Montagu, Isabella 
Beaumont, Margaret Willes Ly Beaumont

da. of John Willes and grda. of Lord Chief Justice Willes, m. Sir George Howland Beaumont (1753-1827), s. of George Beaumont, 6th Baronet and Rachel, da. of Michael Howland, suc. fa in $1767, \mathrm{MP}$.

Beaumont, Thomas Wentworth (1792-1848)

s. of Col. Thomas Richard Beaumont and Diana (d. 1831) ca. and h. of Sir S. W. Blackett Bnt.

MP Northumberland, MP Northumberland and Stafford, suc. fa. in seat in 1818 but lost election in 1826 which led to duel with Lambton, later $\mathrm{E}$. of Durham, at first was a Pitt supporter, then turned to support reform, co-founder of the Westminster Review.

Beauvale, Lady SEE Lamb, Frederick James

Bedford SEE Russell

Bennet, Corisande de Grammont (1783-1865) Cts of Tankerville, Ly Ossulton

da. of Duc de Grammont, French emigre exiled in England, m. Charles Augustus (1776-1859) 5th E. of Tankerville styled Lord Ossulton from 1767-1822, Whig MP, Treasurer of the Household $1806-7$.

Raised under the wing of Georgiana, Ds of Devonshire and at Holland House.

Bentinck, Margaret Cavendish Harley (1715-1785) Ds of Portland

da. of Edward Harley, 2nd E. of Oxford, m. 1734 2nd D. of Portland (1709-1762) [Wheeler Famous Bluestockings p. 32].

Bentinck, William Cavendish (d. 1824) M. of Titchfield

e.s. of 4 th D. of Portland, died before father [Greville George IV vol. 1, p. 75].

Bentinck, William George Cavendish (1802-1848) 4th D. of Portland

Bentinck, William George Frederick Cavendish (Lord George) (1802-1848)

Y.s. of 4 th D. of Portland and Henrietta da. of Maj-gen. scott and sis. of Mrs. Canning.

Army, MP, race enthusiast, private secretary to uncle George Canning.

Bentinck, William Henry Cavendish (1768-1854) 4th D. of Portland

m. 3rd da. of General Scott, sister of Joan Scott Canning, relative of Dundas.

Brother-in-law of George Canning. 
Bentinck, William Cavendish (Lord William) (1774-1839)

2nd $s$. of William Henry Bentinck 3 rd D. of Portland, $m$. 1803 Ly Mary Acheson, da. of Arthur 1st E. of Gosford, no issue.

Gov-gen of India, Whig MP.

Beresford, William Carr (1768-1854) 1st VCt Beresford illeg. s. of George de la Poer, 1st M. of Waterford and E. of Tyrone, m. 1832 Louisa Hope (d. 1851), da. of Rev. William Beresford, his 1st cousin and wid. of Thomas Hope. General, reorganized and commanded Portuguese army in Peninsular War, served in the Wellington cabinet.

Berkeley, Elizabeth (1750-1828) Bns Craven, Margravine of Anspach, and Ps.Berkeley

da. of Augustus, 4th E. of Berkeley, m. (1) William

Crave, 6th Bn Craven (d. 1791), sep. in 1783, m. (2) 1791

Christian Frederick, Margrave of Anspach (d. 1805).

writer and dramatist.

Berry, Mary (1763-1852)

da. of Robert Berry, did not marry.

famous salonist in Curzon Street, close friend of Horace Walpole, co-executor of his literary work, writer.

Bertie, Mary Anne Layard (1743-1804) Ds of Ancaster da. of Major Peter Layard of Canterbury, m. 1769 to Brownlow Bertie, 2nd D. of Ancaster (1729-1809) as 2nd wife, 1 da. [Lyttelton Sarah p. 49].

Bertie, Mary (d. 1793) Ds of Ancaster

da. of Thomas Panton, Master of the King's Running

Horses, m. 1750 Peregrine Bertie, 3rd D. Of Ancaster as 2nd wife.

Mistress of the Robes to Queen Charlotte 1761-93 [Wark Meet the Iadies p. 73].

Bertie, Priscilla Barbara Elizabeth Drummond-Burrell (17611828) Bns Willoughby de Eresby s.j. 1780

m. 1779 Peter Burrell (1754-1820) 2nd Bnt, cr. 1796 Bn Gwydir.

Lady of the Bedchamber to Princess of Wales [Horace Walpole vol. 44, p. 209].

Bessborough SEE Ponsonby

Bouverie, Anne Duncombe Cts of Radnor

da. of Anthony Duncombe, Ld Feversham, m. 1777 Jacob Pleydell Bouverie (1750-1828), 2nd E. of Radnor, e.s. of William Bouverie 1st $\mathrm{E}$., $5 \mathrm{~s}$ 3das.

she inherited burgages at Downton from father. 
Bouverie, Henrietta (Harriet) (1750-1825)

da. Of Everard Fawkener, Amb., sis. of Mrs. Crewe, m. (1) 1762 Edward Bouverie (1738-1810), s. of Jacob Bouverie, 1st Vct. Folkstone, friend of Charles Fox, Whig MP, 3s. 5da. m. (2) 1811 Robert Spencer (1747-1831), s. of Charles Spencer, 3rd D. of Marlborough, cousin to Georgiana, Ds of Devonshire, PC, bro. to Ld Charles Spencer, 1 illeg da.

Bowes, Mary Eleanor Lyons (1749-1800) Cts of Strathmore da. of George Bowes, MP Streatham, Durham, bequeathed 600,000 to his daughter, m. (1) 1767 John Lyon, 9th E. of Strathmore (1737-1776), he took her name, 3s 5da, m. (2) 1777 Andrew Robinson Stoney (1747-1810), MP Newcastle, 2 ch. He abused and kidnapped her, div. 1789. Buried at Westminster Abbey.

Boyle, Lady (d. 1758) Cts. of Burlington

m. Richard Boyle, 3rd E. of Burlington (1694-1753), mo. of Charlotte who m. William Cavendish, 4th D. of Devonshire. controlled the borough of Knaresborough from the death of her husband in 1753 until her death in 1758 .

Boyle, Mary (1746-1845) Cts of Cork and Orrery

da. of Vct. Galway, m. 1786 Edmund Boyle (d. 1798), 7th E. of Cork as 2nd wife.

hostess to several generations from Johnson to Burke to Byron and scott.

Breadalbane SEE Campbell

Brougham and Vaux, Henry Peter Brougham (1778-1868) 1st Bn

s. of Henry Brougham and Eleanor, da. Mrs. Syme, m. 1821 Mary Anne, da. of Thomas Eden and wid. of John Spaulding, no sur. ch.

Whig politician and lawyer, MP 1810-30, defense attorney for Queen Caroline in 1820, Lord Chancellor 1830-33, Founder of the Society for the Diffusion of Useful Knowledge in 1827, founder of University College, London in 1828. Advisor of the Princess of Wales. Affair with Mrs. George Lamb.

Buccleuch SEE Scott

Buckingham SEE Grenville

Buckinghamshire SEE Hobart

Bunbury SEE Napier 
Burdett, Francis (1770-1844) Radical politician

s. of Robert Burdett, 4th Bt, m. 1793 Sophia Coutts, da. of Thomas Coutts, wealthy banker, fa. of Angela, Bns Burdette-Coutts, a noted philanthropist.

Burghersh, Lady SEE Fane, John (1784-1859)

Burke, Edmund (1729-1797) Whig politician, philosopher

m. 1756 Jane Nugent, da. of his physician, $2 \mathrm{~s}$.

leader of the Rockingham Whigs in Fox-North Coalition, 1790 broke with Foxite Whigs over their support of the French Revolution.

Burlington, ct. of SEE Boyle, Lady (d. 1758)

Burlington, Elizabeth Cavendish SEE Cavendish

Burney, Frances (Fanny) D'Arblay (1752-1840)

da. of Charles Burney, fashionable musician, m. 1793

Alexandre d'Arblay, $1 \mathrm{~s}$. who predeceased her.

2nd Keeper of the Robes 1786-1791, kept Windsor journal, major novels include Evalina (1777); Cecilia (1782); Camilla (1796), member of literary circle based at Streatham, which included Dr. Samuel Johnson, the Thrales, Edmund Burke, Joshua Reynolds, and Elizabeth Montagu.

Burrell, Drummond, Mrs. SEE Bertie, Priscilla

Bute SEE Stuart

Butler, Bmily (1767-1836) Cts of Glengall

$y$. da. of James St. John Jeffreys of Blarney Castle, Co. Cork, m. 1793 Pierce Butler, 11th Bn Cather and 1st E. of Glengall (d. 1819) [Aspinall Three p. 5].

Calonne, Charles Alexandre de (1734-1802) French politician, Comptroller-General of Finance 1783-1787 under Louis XVI, lived in England 1787-1802 [Lady Holland Journal vol. 1, p. 23] .

Campbell, Mary Turner (d. 1845) Cts of Breadalbane da. of David Gavin of Langton House, Berwick, $m$. John Campbell (1762-1834), 4th E. and 1st M. of Breadalbane.

Canning, George (1770-1827)

m. Joan Scott (d. 1837)

entered HC 1794, under the aegis of Pitt, the Younger, President of the India Board of Trade 1816-1821, For. Sect. 1807-8, 1822-7, PM 1827, duel with Castlereagh, leader of the progressive Tories. Supposed affair with Queen Caroline. 
Canning, Joan Scott (d. 1837) Vcts Canning

da. of Major-General John Scott of Balcomie, Fifeshire, sis. of Lady Titchfield, later Ds of Portland, m. George Canning (1770-1827), PM 1827, cr. Vcts Canning in 1828, after husband's death, mo. of Lady Clanricarde.

Canning, stratford (1786-1880) 1st Vet Stratford de Redcliffe

s. of Stratford Canning and Mehitabel Canning, cousin of George Canning, m. (1) 1816 da. (d. 1818) of Henry Raikes, m. (2) $1825 \mathrm{da}$. of James Alexander, MP, $3 \mathrm{ch}$.

diplomat, MP 1828-41, expert on the Eastern Question.

Carlisle SEE Howard

Carlisle, Lady see Howard, Margaret

Carter, Elizabeth (1717-1806) writer, linguist, translator, Bluestocking

da. of Dr. Nicholas Carter, curate at Canterbury

Cathedral and Margaret, da. of Richard Swayne.

associated with Dr. Samuel Johnson, close friend of Elizabeth Montagu, wrote Rambler \#44 and \#100.

Cartwright, John (1740-1824) Radical candidate, "Father of Reform"

s. of William Cartwright, m. 1780 Anne Katherine Dashwood (d. 1834), no issue.

Radical candidate, "Father of Reform".

Castlereagh SEE Stewart

Cavendish, Elizabeth Compton (1760-1835) Ly George

Cavendish, Cts of Burlington

da. of Charles, 7th E. of Northampton, m. 1782 Ld George Cavendish (1754-1834), cr. in $1831 \mathrm{E}$. of Burlington, y. s. of William, 4 th D. of Devonshire, $10 \mathrm{ch}$., mo. of Charles Compton $[N \& B]$.

"She died one year after her husband which caused the 6 th Duke of Devonshire to observe: 'Poor Aunt George, only one year of happiness'" [Second Self p. 301].

Cavendish, Georgiana (1757-1806) Ds of Devonshire

da. of John, 1st E. Spencer and Margaret Poyntz, m. 1774 William Cavendish, 5th D. of Devonshire (1748-1811), $3 \mathrm{ch} .$, 1 illeg ch. with Charles Grey in 1791, sis. of harriet, Ly Bessborough.

Whig political hostess, close friend of Charles Fox, the Prince of Wales, and Sheridan. 
Cecil, Mary Amelia (Emily) Hill Cranbourne (1750-1835) Cts of Salisbury, Ly Cranbourne

da. of Wills, Ist M. of Downshire and Margaretta, sis. of James, 1st D. of Leinster, sis. of Arthur Hill, m. 1773 James Cecil (1748-1823), 7th E. and 1st M. of Salisbury, Vct Cranbourne until 1780, Tory MP, $3 \mathrm{ch}$, burned to death at Hatfield House, Cecil family home.

Cecil, Frances Mary (d. 1839) Vcts Cranbourne, Cts of Salisbury

da. of Bamber Gascoyne (1725-1791), Tory MP, m. 1821 to James Cecil, Vct Cranbourne, 2nd M. of Salisbury (17911868), close friend of Wellington.

Chapone, Hester Mulso (1727-1801) Bluestocking, essayist da. of Thomas Mulso, m. 1760 John Chapone (d. 1761), an attorney, no children.

Bluestocking, essayist, good friend of Richardson, Carter, Johnson, minor contributor to Johnson's periodicals [Uglow 1989 and Rogers Feminism in 18th Century England p. 256].

Chatham SEE Pitt

Churchill, Sarah Jennings (1660-1744)

m. John Churchill, 1st D. Of Marlborough (1652-1722).

Lady in waiting to Queen Anne.

Clancricarde SEE De Burgh

Clarence, Duke of See William IV

Clifford, Augustus (1788-1877) 1st Bnt

illeg. s. of Elizabeth Foster and 5th D. of Devonshire, half bro. of Harriet Granville, Georgiana Howard, and 6th D. of Devonshire.

admiral.

Clive, Edward (1754-1839) 1st E. of Powis

m. 1784 Ly Henrietta Antonia Herbert, da. of Henry

Author, E. of Powis of the Herbert creation, $2 \mathrm{~s} 2$ das. I s Edward, 2nd E. of Powis m. 1818 Ly Lucy Graham, half sis. of Ly Jersey, Ly Bessborough, and Ly Paget.

Gov. of Madras.

Cochrane, Ratherine Frances Corbet Barnes (1796-1865) Cts of Dundonald

m. 1812 Thomas Cochrane (1775-1860), 10th E. of Dundonald, captain during Napoleonic Wars, imprisoned for fraud in 1814, expelled from navy, released and returned to navy, MP 1806-7 Honiton and Westminster, $2 \mathrm{ch}$. 
Coke, Anne Amelia Keppel (d. 1844)

da. of William Charles, 4th E. of Albemarle, m. (1) 1822 Thomas Coke, Coke of Norfolk $5 \mathrm{ch}, \mathrm{m}$. (2) 1842 Edward Ellis, MP [Lady Holland Journal vol. 1, p. 145, n. 1].

Coke, Thomas William (1754-1842) Coke of Norfolk, Coke of Holkham, 1st E. of Leicester

s. of Wenman Roberts Coke (d. 1776), h. to uncle Thomas Coke (1697-1759), cr. 1837 1st E. of Leicester, m. (1) 1755 Jane Dutton (1753-1800), his cousin, sis. of James, 1st Bn. Sherbourne, 3das., m. (2) 1822 Ly Anne Amelia Keppel (d. 1844), da. of William Charles 4th E. of Albemarle, 5s 1da

Whig politician and agriculturalist, MP 1776-1806, 18071832 .

Colville, Ann (1800-1852) Ly

da. of Edward Law, Ld Ellenborough, chief Justice of England, sis. to Ld Ellenborough (1790-1871) 2nd Bn and 1st E., Gov-gen of India, m. 1841 John, 10th Bn Colville as 2nd wife.

Compton, Joshua SEE Cavendish, Elizabeth

Conyngham, Elizabeth Denison (1769-1861) Cts. of Conyngham da. of Joseph Denison, wealthy merchant, m. 1794 Henry, 3 rd $\mathrm{Bn}$ and 1st $\mathrm{M}$. of Conyngham, mistress to George IV [3:283].

Pss. Lieven said "'she did not belong to the kind of society one invites to dinner" " [Second Self p. 302].

Cooper, Anthony (1801-1885) 7th E. of Shaftesbury, Ld Ashley e.s. of 6 th E. of Shaftesbury and Anne, da. of $3 \mathrm{rd} D$. of Marlborough, m. Emily Cowper (d. 1872) da. of Emily Cowper/Palmerston, 6s, 4das., fa. of Ly Barbara Ashley Cooper who m. William Ponsonby, s. of Harriet Ly Bessborough.

supporter of Canning and Liverpool, philanthropist, leader of the factory reform movement, flirt of Ly Cowper [Jrl of Mrs. A. vol. 2 p. 338].

Copley, John Singleton (1772-1863) 1st Bn Lyndhurst

s. of John Singleton Copley, the Elder, m. 1819 Sarah Garay, wid. of Charles Thomas.

Tory Lord Chancellor 1827-30, 1834-5, 1841-6.

Copley, Sarah Garay Brunsden (1795-1834) Cts of Lyndhurst da. of Charles Brunsden, m. (1) Lieut-Col. Charles Thomas of the Coldstream Guards, m. (2) 1819 John Singleton Copley, 1st Bn Lyndhurst.

Cork SEE Boyle 
Cornwallis, Charles (1738-1805) lst M. Cornwallis

e. S. of Charles 1st E. Cornwallis and Elizabeth, da. of Ld Townshend and niece of Sir Robert Walpole, m. 1768 Jemima Tullikens, da. of Col. James Jones.

opposed taxation of American colonists but served in war, surrendered at Yorktown, Gov-gen of India, Ld-Lt. of Ireland.

Cowper, Lady SEE Nassau

Cowper, william (1731-1800) Poet

Crauford, Anna Maria (d. 1834) Ds. of Newcastle da. of 2nd E. of Harrington, m. (1) Thomas, $3 r d$ D. of Newcastle, I s., m. (2) 1800 Charles Crauford (1761-1821) 2nd $s$. of Alexander Crauford MP, no issue.

Creevey, Thomas (1768-1838) Whig MP, friend of Fox, and the Prince of Wales

s. of William Creevey, merchant, or might be natural son of Ld Molyneaux, 1st E. Sefton, m. 1802 Eleanor Ord (d. 1819), da. of Charles Brandling, MP and wid. of William ord, distant cousin of Charles Grey, 2nd E. Grey, 5 ch., wealthy. his attacks on the Grenvillites helped split the Whig party, author of History of our Times.

Crewe, Frances Anne Greville (1742-1818) Ly Crewe

da. of Fulke Greville and Frances, da. of James Macartney, sis. of Mrs. Bouverie and Charles Greville, m. 1766 John Crewe (1742-1829) of Crewe Hall, Cheshire, cr. Bn Crewe 1806, MP Chester, founder of Brooks Club, leading agriculturalist.

friend of Fox, Reynolds, Burke, Burneys, Thrales, and Canning [Thorne].

Croker, John Wilson (1780-1857)

s. of John Croker, Surveyor-gen of Ireland, m. 1806 Rosamund Pennell, da. of William Pennell a consul in South America, no surviving issue.

essayist and diarist, anti-reformer, entered HC 1807, retired upon passage of the Reform Bill of 1832, Portland Whig then Tory.

Cumberland, Albinia (1759-1853) Ly Cumberland da. of $3 \mathrm{rd} \mathrm{E}$. of Buckinghamshire, sis. of Ld Hobart, $m$. Richard Cumberland, army officer, $s$. of Richard Cumberland, the dramatist.

Lady of the Bedchamber to Younger Princesess [Aspinall Later vol. 4, p. 149, n. 1]. 
Cumberland, Ernest Duke of (1771-1851) King of Hanover s. of George III, bro. of George, Pr. of Wales, m. Fredericka Caroline (1778-1841), Pss. of MecklenburgStrelitz

Damer, Anne Seymour Conway (1749-1828) Artist da. of Field Marshall Henry Seymour Conway, m. 1767 John Damer, s. of E. of Dorchester (d. 1776), cousin and close friend of Horace Walpole, who gave her strawberry Hill for her lifetime [EBW].

D'Arblay SEE Burney

De Burgh, Harriet Canning (1804-1876) Cts of Clanricarde da. of George Canning (1770-1827) and Joan Scott Canning (d. 1837), m. 1825 Ulrich John de Burgh (1802-1874) 14th E. and lst $M$. of Clanricarde under secretary for foreign Affairs 1826-7, Amb. at St. Petersburg 1838-41, cabinet under Palmerston and Russell, $7 \mathrm{ch}$.

Deffand, Marie de Vichy-Chamrond du (1697-1780) Marquise, French salonist and intellectual

m. 1718 Jean Baptiste de la Lande, sep. 1722

French salonist and intellectual, leader of the court surrounding her lover, regent Phillipe II, Duc' Orleans, friend of Voltaire and Horace Walpole, salon flourished 1753-1780, her companion was Julie de Lespinasse [Uglow 1989].

Delany, Mary Granville Pendarvis (1700-1788) writer, artist da. of Bernard Granville (d. 1723), bro. of George Granville, 1st Ld Lansdowne, m. (1) 1717 Alexander Pendarvis of Cornwall (d. 1725), no issue, m. (2) 1743 Dr. Patrick Delaney (d. 1768), no issue.

friend of Swift, Burney, and other bluestockings, favorite of the Royal family, King gave her house at Windsor, friend of the Duchess of Portland.

Derby, Cts. of SEE Stanley, Elizabeth

Devereaux, Henrietta Charlotte Keck Tracy Vcts Hereford da. of Anthony Keck (1708-1767), m. 1774 Edward Devereaux (d. 1783), 12th Vct. Hereford.

Devonshire SEE Cavendish

Disraeli, Benjamin (1804-1881) Ist E. of Beaconsfield m. 1839 Mary Anne Lewis, widow of Wyndham Lewis.

Tory PM and novelist. 
Dod, Charles Roger Phipps (1793-1855) newspaper writer

s. of Rev. Roger Dod and Margaret Phipps, m. 1814 Jane Eliza, da. of John Baldwin of Cork.

author of Parliamentary Companion, Parliamentary Pocket Companion, and Electoral Eacts.

Dorset SEE Sackville

Douglas, Katherine Anne North (1760-1817) Ly Glenbervie da. of Frederick, Ld. North, PM, m. 1789 Sylvester Douglas, Ld. Glenbervie (1743-1823).

1807 Ly in Waiting to the Princess of Wales.

Dover SEE Ellis

Duff, James $(1776-1857)$ 4th E. of Fife s. of Alexander Duff, 3rd E. Fife, m. 1799 Mary Caroline (d. 1805), d. of John Manners, no issue.

MP, Ld. in Waiting 1819-1821 [Jr] of Mrs. A, vol. 1, p. 98].

\section{Duncannon SEE Ponsonby}

Dundas, Robert Saunders (1771-1851) 2nd Vct Melville

s. of Henry Dundas, 1st Vct Melville, m. Anne, da. of Richard Huck Sanders, MP Rye.

Tory, 1st Ld. of the Admiralty 1812-28, 1828-30.

Dundas, Henry (1742-1811) 1st Vct Melville

s. of Robert Dundas of Arniston and Anne, da. of Sir William Gordon of Invergordon, m. (1) 1765 Elizabeth, da. of David Rennie of Melville Castle, 4 ch, m. (2) 1793 Ly Jane Hope (d. 1829), da. of John, 2nd E. of Hopetoun, no issue. She married in 1814 Thomas, Ld. Wallace.

friend of Pitt, the Younger. MP 1774, Treasurer of Navy 1784-1800, 1st Ld. of the Admiralty 1804-5. Accused of misappropriation of Admiralty funds but acquitted in 1805 . strong patronage and election manager [DBH].

Durham SEE Lambton

Dyce, Alexander (1798-1869)

editor of Recollection of the Table Talk of Samuel Rogers and noted editor of Shakespeare.

Eden, Emily (1797-1869) novelist and traveller

da. of William Eden, lst bn Auckland, sis. of George Eden, 2nd Bn Auckland, did not marry.

to India with brother in 1835-1842, political salon in Kensington was Eden Lodge. 
Eden, George (1784-1849) 2nd Ld. Auckland

s. of Eleanor Elliot, sis. of the 1st E. of Minto and William Eden, 1st Bn Auckland, bro. of Emily Eden, did not marry.

1830 in Whig cabinet of Grey and Russell, 1834 1st Ld. of the Admiralty, 1835-1841 Gov-Gen of India.

Eldon SEE Scott

\section{Ellenborough SEE Law}

\section{Ellice, Edward (Bear) (1781-1863)}

m. 1843 Elizabeth, Dow, Ds of Leicester the 2nd w. of Coke of Norfolk, brother-in-law to 2nd E. Grey.

connected to the Canadian fur trade, entered HC 1818, Sect to Treasury, sect at War, founder of the Reform Club in 1836.

Elliot, Anna Maria (1751-1814) Cts. of Minto e. da. of Sir George Amyand, m. 1777 Gilbert, 1st E. of Minto, 3s 3 das.

Whig.

Ellis, Georgiana Howard (1804-1860) Vcts Ellis, Ly Dover da. of Georgiana Cavendish Howard and George, 6th E. of Carlisle, grda. of Georgiana, Ds of Devonshire, m. 1822 George James Welbore Agar Ellis (d. 1833), s. of 2nd Henry Welbore Agar Ellis, Vct Clifden, and Caroline Spencer, da. of George, 3rd D. of Marlborough, cr. 1831 Ld. Dover, Whig MP, Canning supporter, $7 \mathrm{ch}$.

Elphinstone, George Keith, (1746-1823) Vct Keith, Adm. s. of Charles, 10th Ld. Elphingstone, m. (1) 1787 Jane (d. 1789), da. of Col. William Mercer of Aldie, fa. of Margaret Mercer (1788-1867), Vcts Keith, who married Comte de Flahault, French Amb. in London, and friend of Charlotte, Ps of Wales, m. (2) 1808 Hester Maria (1762-1857), da. of Hester Thrale, one of the original patroness of Almack's, 1 da.

\section{Esterhazy, Pss Therese (1794-1876)}

da. of Charles, P. of Thurn and Taxis, m. 1812 to P. Paul Esterhazy, Austrian Amb. to Britain 1815-1842, mo. was 1st cousin of George IV.

Almack's patroness [Jr] of Mrs. A. vol. 1, p. 29, n. 2].

Fane, John (1784-1859) 11th E. of Westmoreland, known as Ld. Burghersh from 1784-1841

s. of John, 10th E. of Westmoreland, m. Priscilla Anne Fane (1793-1879), da. of William Wellesley-Pole, 3 rd E. of Mornington, linguist, artist, niece of $\mathrm{D}$. of Wellington. diplomat, musician, founder of Royal Academy in 1823, MP. 
Fane, John (1759-1841) 10th E. of Westmoreland

s. of John, 9th E., m. (1) 1782 Sarah Anne Child (d. 1793), da. of Robert Child, banker, 4 ch., m. (2) 1800 Jane, da. of Richard Huck Sanders, MD, 4 ch., lst cousin to Mrs. Arbuthnot, fa. of Sally Jersey.

Ld. Lieut. of Ireland 1790-5, Ld. Privy Seal 1798-1827.

Fane, Mary Cavendish (1700-1778) Cts of Westmoreland

da. of Ld. Henry Cavendish, m. 1716 John Fane, 7th E. of Westmoreland, no issue.

Fane, Mildmay (1794-1869)

bro. of Mrs. Arbuthnot [Jr] of Mrs. A, vol. 1, p. 7].

Fife SEE Duff

Fitzgerald, Emilia Mary Lennox (1731-1814) Ds of Leinster da. of Charles, 2nd D. of Richmond and Ly Sarah Cadogan, sis. of Caroline, m. to Henry Fox, 1st Ld. Holland, sis. of Ly. Sarah Napier, m. 1747 James Fitzgerald (1722-1773), E. of Kildare, Vct Leinster, cr. D. of Leinster in 1766 as the Ist Irish Duke.

Fitzgerald, Emilia Olivia St. George (d. 1798) Ds of Leinster

da. of Ld. St. George Ussher, m. 1775 William Robert, 2nd D. of Leinster (1749-1804), s. of James, Ist D. of Leinster and Ly Emily Lennox.

Fitzharris SEE Malmesbury

Fitzherbert, Maria Anne Smythe, Mrs. (1756-1837)

da. of Walter Smythe of Brambridge, Hampshire, Catholic family, m. (1) 1775 Edward Weld of Lulworth Castle, Dorset (d. 1775), m. (2) 1778 Thomas Fitzherbert of Swinnerton Hall, Staffordshire (d. 1781), m. (3) 1785 George, P. of Wales but marriage was invalid under Royal Marriage Act, sep. 1803, she received 6,000 per year after they separated, no issue.

Fitzjames, Ds. of

da. of Napoleon's Ist wife Josephine by her lst husband, the Comte de la Touche who was guillotined during the Revolution, m. D. Of Fitzjames (1743-1805) great grandson of James II.

Fitzpatrick, Anne Liddell (d. 1804) Cts of Upper Ossory m. (1) 3rd D. of Grafton, m. (2) John Fitzpatrick (17451818), 2nd E. of Upper Ossory, sep. 1765, div. 1769

friend and correspondent of Horace Walpole [Horace Walpole vol. 32, p. 277]. 
Fitzwilliam SEE Wentworth

Foster, Augustus John (1780-1848) Ld Foster

s. of Elizabeth Foster and John Foster, Irish MP, m. 1815, Albinia Jane, da. of George Vere Hobart.

at the legation at Naples, the United States, MP, cr. Bnt 1831.

Foster, Elizabeth Hervey (1748-1824) Ds of Devonshire da. of Frederick Augustus Hervey, the E. of Bristol and BP of Derry, m. (1) John Thomas Foster, Irish MP (d. 1796), 2s, m. (2) 1809 William Cavendish, 5th D. of Devonshire (d. 1811), 2 illeg. ch. with him.

"Ambitious and a schemer" [Second Self p. 302].

Fox, Charles James (1749-1806) Whig politician

s. of Henry Fox, 1st Bn Holland and Caroline, da. of

Charles Lennox, 2nd D. of Richmond, m. Elizabeth Bridget

Cane, Mrs. Armistead

cabinet of Rockingham, Portland and the Talents Ministry, rival of Pitt, supporter of American and French Revolutions.

Fox, Caroline (1767-1845)

sis. of Henry, 3rd Bn Holland, did not marry.

hostess at Little Holland House.

Fox, Elizabeth Vassall (1770-1845) Ly Holland

da. of Richard Vassall of Jamaica, m. (1) 1786 Sir

Godfrey Webster, Bt of Battle Abbey, Sussex, div. 1797, 3

ch., m. (2) 1797 Henry Richard Fox, 3rd Bn Holland (17731840), by Holland before their marriage had 1 son Charles Richard Fox m. 1824 Ly Mary Fitzclarence da. of William IV by Mrs. Jordan, 3 other $\mathrm{ch}$. with Holland.

political and literary hostess at Holland House, Kensington created social center of the Whig party, $C$. Greville called it the "House of All Europe."

Fox, Henry Vassall (1773-1840) 3rd Bn Holland

s. of Stephen, 2nd Bn Holland and Ly Mary Fitzpatrick, da. of John, E. of Upper Ossory, nephew of Charles Fox. Whig politician, cabinet of the Talents Ministry, Grey, and Melbourne.

Gage, Henry Hall (1791-1877) 4th Vct

s. of Henry Gage (d.1808).

1 of 22 peers who refused to abstain and voted against the 3 rd reading of the Reform Bill of 1832. Holland House Diaries p. 457, n. 175 . 
Galloway, John (1736-1806) Ld. Garlies, 7th E.

m. (1) 1762 Charlotte Mary Greville, da. of 1st E. of Warwick, m. (2) 1764 Anne, da. of Sir James Dashwood, 8s 8 das.

MP, Ld. of the Bedchamber 1784-1806 Aspinall Later vol. 1, p. 454, n. 1 .

Geoffrin, Marie-Therese Rodet de (1699-1777) French salonist da. of a valet, $m$. a rich bourgeois merchant.

she was head of the bourgeois salon while Mde Du Deffand was head of the aristocratic salon [Uglow 1989].

George III $(1738-1820)$

reigned 1760-1820, Regency 1811-1820.

George IV $(1762-1830)$

Prince Regent 1811-1820, reigned 1820-1830.

m. 1785 illegally Mrs. Fitzherbert, sep. 1811, m. 1795 Caroline of Brunswick (1768-1821), affair with Ly Jersey, broken off in 1794, 1807 affair with LY Hertford, affair with Lady Conyngham.

Glengall SEE Butler

Goderich SEE Robinson

Gordon, Mrs. (El. 1832) Hon.

heiress of Vct. Kenmure

at New Galloway in Kirkcudbrightshire, Scotland [N\&B].

Gordon, George Hamilton Gordon (1784-1860) 4th E. of Aberdeen

Tory politician

s. of George Gordon, Ld. Haddo, Pitt and Dundas were his guardians, m. (1) 1805 Catherine Elizabeth Hamilton (d.

1812), da. of M. of Abercorn, 3da., m. (2) 1815 Harriet, da. of James Douglas and wid. of James, Vet Hamilton, 4s.

cabinet member under Peel, Wellington, and Peel, leader

of the Peelites, settled the Oregon border dispute.

Gordon, Jane Maxwel1, (1749-1812) Ds of Gordon, Tory political hostess

da. of Sir William Maxwell of Monreith, 3rd Bt of Monreith, sis. of Ly Wallace, m. 1767 Alexander Gordon, 4th D. of Gordon, 2s $5 \mathrm{da}$.

cr. social center for Tory party, "Queen of the Tories", confidant of Pitt, patron of Robert Burns and William Marshall. 
Granville, Elizabeth (Duchess-Countess) (1765-1839), Ds of Sutherland s. j.

da. of William, 18th E. of sutherland, m. 1785 George Granvilie Leveson-Gower, Ld. Gower, cr. D. of Sutherland in 1833 (d. 1833).

Tory, very wealthy. "Her high standard in society did little to sweeten her temper or moderate her dominating attitude" [Second Self p. 307].

Granville, Francis Leveson Gower(1800-1857) E. of Ellesmere 2nd $s$. of 2 nd $M$. of Stafford and 1 st $D$. of Sutherland, $m$. 1822 Harriet Greville, sis. of the diarist, took grandmother's name of Egerton in 1833, cr. E. of Ellesmere in 1846, inherited large amount of money from gt. uncle $3 r d$ D. of Bridgewater.

Protegee of Lady Holland [Second Self p. 305; Lady Holland to her Son p. 11, n. 3].

Granville, George (1758-1833) 1st D. of Sutherland, 2nd M. of Stafford

m. 1785 Elizabeth Cts. of Sutherland s. j. and Bns of Strathnaver.

liberal supporter of Catholic Emancipation and the Reform Bill of 1832, responsible for the highland clearances in Sutherland.

Granville, George Granville Leveson Gower (Id Gower) (17861861) E. Gower, M. of Stafford, 2nd D. of Sutherland

e. s. of 2nd $M$. of stafford and 1st D. of Sutherland, suc. 1803 as E. Gower when fa. suc as 2nd M. of Stafford, suc. 1833 as 3 rd M. of Stafford when fa. was cr. D. of Sutherland, suc. 1833 as 2nd D. of Sutherland when fa. died, $\mathrm{m}$. Ly Harriet Howard, da of Georgiana (Little G) and 6th E. of Carlisle, grda. of Georgiana Ds. of Devonshire, she was his cousin, 4s 7 das.

Tory MP

Granville, Granville George Leveson-Gower (1815-1891) 2nd E. Granville

e. s. of Ld Granville (1773-1846) 1st E. Granville and Harriet (Hary-O) (1785-1862) da of Georgiana Ds. of

Devonshire, m. (1) 1840 Marie (d. 1860), da of Duc Dalberg and wid. of Sir Ferdinand Acton, m. (2) 1865 Castalia

Rosalind Campbell, da of Walter Frederick Campbell of Islay, 2 s 2das.

liberal politician, MP 1836-86, ally of Gladstone, served in many cabinets. Castalia was editor of Lord Granville's correspondence.

Granville, Henrietta (Harriet) (1806-1868)

da. of Georgiana Cavendish Howard "Little G", grda. of Georgiana, Ds of Devonshire, m. 1823 George Granville, E. 
Gower, later 2nd D. of Sutherland, 20 years younger than her husband, $11 \mathrm{ch}$. hostess at Stafford House, center for anti-American slavery, Mistress of the Robes while Whigs were in office, one of the women involved ion the Bedchamber Crisis of 1839 . Victoria spent first months of widowhood with Harriet. "Known for her wit and intelligence" [Second Self p. 303].

\section{Granville, Henrietta Elizabeth Cavendish (Hary-0) (1785- 1862) \\ da. of Georgiana, Ds of Devonshire, m. 1809 George Granville Leveson Gower, Ld Granville (1773-1846), E. Granville mistress of the Robes to Queen Victoria.}

Granville, Leveson-Gower (1721-1803) VCt Trentham, E. Gower, M. of Stafford 3rd s. of John, 1st E. Gower by his 1st wife, Ly Evelyn Pierrepont, da. of Evelyn, 1st D. of Kingston, m. (1) 1744 Elizabeth (d. 1745), da. of Nicholas Fazakerly, no issue, m. (2) 1748 Ly Louisa Egerton (d. 1761), da. and coh. of Scroop, 1st D. of Bridgewater, is 3da., m. (3) 1768 Susannah Stewart (d. 1805), da. of John 6th E. of Galloway, 2s 2das., suc as 2nd $E$. Gower in 1754, Cr. M. of Stafford in 1786, fa. of Ld. Granville (1773-1846) and fa. of George Granville (1758-1833)

Tory politician, Ld. of the Admiralty, Privy Council, Ld. Privy seal.

Granville, Leveson-Gower George (1773-1846) styled Ld. Granville, lst E. Granville

3rd s. of Granville, 2nd E. Gower (1721-1803) and his 3rd wife Susannah Stewart, Ly Stafford (d. 1805), da. of Alexander, E. of Galloway, cr. 1833 lst E. Granville, long time affair with Harriet, Ly Bessborough, 2 illeg. ch., m. 1809 Ly Harriet Cavendish (Hary-O), da. of Georgiana, Ds of Devonshire.

Gower Whig/Tory, but with Whiggish leanings, under the influence of Harriet, Ly Bessborough, MP 1795-99, British Amb. to France, cr. Vct 1815, cr. E. 1833. "Clever, handsome, and selfish" [Second self" p. 303].

Grenville, Elizabeth (d. 1769) Ly

da. of William Windham Bnt, sis. of Charles, 2nd $E$. of Egremont, m. George Grenville (1712-1770) PM, 3s 5das., his sister, Hester, m. William Pitt, sons were George (d. 1813), Thomas (d. 1846), William Wyndham (d. 1834).

Tory Treasurer of the Navy 1760, Secretary of State 1762, PM $1763-65$.

Grenville, George Nugent Temple (1753-1818) 3rd E. Temple 
Grenville, Mary Elizabeth Nugent (d. 1812) Bns Nugent, Cts. Temple, Cts Buckingham

da. of Vct Clarke, E. Nugent (1702-1788), m. 1775 George Grenville, (1753-1813) 2nd son of Rt. Hon. George Grenville, suc uncle as 2nd $E$. Temple in 1799, $c r$. M. of Buckingham in 1784, added names of Temple and Nugent, cr. Bns Nugent in 1800 with special rem. to 2nd s. Ld George.

leader of the Grenvillite Tories, Ld. Lt. of Ireland 1782-4, 1787 [Aspinall Later vol. 1, p. 307, n. 1].

Grenville, Richard Buckingham and Chandos (1791-1861) 2nd D. of Buckingham and Chandos

Tory politician, MP Buckinghamshire 1818-1839.

Grenville, Richard Temple-Nugent-Brydges-Chandos (Ld.

Temple) (1776-1839) Styled E. Temple from 1784-1813, M. of Buckingham, D. of Buckingham and Chandos.

e. s. of George Nugent Temple Granville and Ly Mary

Elizabeth Bns Nugent, s. j., m. Anna Elizabeth Bns Kinloss s.j.

Tory, then Whig, held office under Ld John Townshend $1806-7$.

Grenville, Thomas (1755-1846)

2nd s. of George Grenville (1712-1770) and Elizabeth, da. of William Wyndham.

Whig politician and friend of Sheridan, book collector, diplomat, minister at Paris 1782, Amb. at Vienna 1793.

Grenville, William Wyndham (1759-1834) Bn Grenville

$3 r d s$. of George Grenville (1712-1770), m. 1792 Anne Pitt (d. 1864), da. of Thomas, 1st Bn Camelford.

Whig leader, PM 1806, entered Commons in 1782, Commons Opposition leader, Home Sect. 1781-91 under Pitt, his cousin. Then aligned with Charles Fox in 1804. Talents Ministry, Leader of the conservative Whigs. 1822 supporter of Liverpool, from Tory family.

Greville, Charles (Punch) (1794-1865)

s. Of Charles Greville (1749-1809), grandson of 5th $\mathrm{E}$. of Warwick and Ly Charlotte Bentinck (d. 1862), only da. of 3 rd $D$. of Portland and close friend of the D. of Wellington. political diarist, both whig and Tory connections, friends of Wellington, D. of Bedford, Palmerston. Privy Purse to the D. of York, Clerk to the Council [Second Self p. 304].

Greville, Frances (d. 1789)

nee Macartney, m. Richard Fulke Greville of Wilbury House, mo. of Frances Crewe [2:277]. 
Grey, Charles (1764-1845) 2nd E. Grey, Vct. Howick

s. of Lt-Gen Sir Charles Grey, 1st E. Grey (1729-1807), m. 1794 Mary Elizabeth Ponsonby (1776-1861), da. of William Brabazon, lst Bn Ponsonby of Imokilly, $15 \mathrm{ch}$, affair with Georgiana, Ds of Devonshire resulted in $1 \mathrm{ch}$.

Reform Bill PM 1830-4, Whig MP, friend of Fox, entered HC 1786, 1806 Admiralty.

Grey, Jemima Yorke Bns Lucas of Crudwell, Mar. de Grey sis. of 2nd E. of Hardwicke.

Grey, Maria Copley (d. 1879) Ly Howick, Cts Grey

da. of Sir Joseph Copley, m. Henry (1802-1894), 3rd E.

Grey, Ld Howick until 1845, whig MP, cabinet of Grey,

Melbourne, Russell, and Palmerston, Whig leader in the Ld.s, no issue.

Grosvenor, Elizabeth Mary Leveson-Gower Mar. of Westminster, Lady Belgrave

da. of Ist D. of Sutherland, m. 1819 Richard Grosvenor, 2nd M. of Westminster (1795-1869) Ld. Belgrave, MP.

Grote, Harriet (1792-1878) biographer, politician

nee Lewin, near Southampton, m. George Grote (1794-1871),

s. of a banker, Radical MP, no issue.

created a center of Radical politics. "Cobden and Place

asserted that she might have led the Radicals had she been a man" [EBW].

Hardinge, Henry (1785-1856) 1st Vat

$3 r d \mathrm{~s}$. of Henry hardinge, rector and Frances, da. of

James Best, m. 1821 Emily Jane Stewart James (d. 1865) half sis. of 2nd $M$. of Londonderry (Ld. Castlereagh) and wid. of John James, minister to the Netherlands, 2s. 2 das.

tory, soldier, entered HC 1820, sect. at war under

Wellington, Irish Sect., Gov-gen of India, Commander-in

Chief $1852-55$.

Hardwicke SEE Yorke

Harris, James (1746-1820) 1st E. of Malmesbury

$s$. of James Harris and Elizabeth Clarke, m. 1777 Harriet Mary, da. of Sir George Amyand, Bt, cr. Bn in 1788, cr. E. in 1800 . Whig MP, diplomat, served under Pitt and Canning.

Harris, James Edward Harris (d. 1841) 2nd E. of Malmesbury m. Harriet Susan (d. 1815), da. of Francis Bateman

Dashwood

undersecretary for Foreign Affairs under Canning in 1807, Gov. of the Isle of Wight. 
Harris, James Howard (1807-1889) 3rd E. of Malmesbury, Id. Fitzharris until 1841

m. (1) 1830 Ly Emma Bennet (d. 1876), da. of 5th E. of Tankerville, no issue, $m$. (2) 1880 Susan, da. of John Hamilton, no issue, suc. by nephew, Col. Edward James Harris.

Harrowby, SEE Ryder

Hawkesbury SEE Jenkinson

Hay, Robert Auriol 9th E. nephew of Thomas Hay (1710-1787) 8th E.

Herbert ( $f 1$. 1740s) Ly Pembroke $\mathrm{m}$. to Thomas (d. 1733) 8th E. of Pembroke.

Herbert, Elizabeth (1737-1831) Cts of

da. of 2nd D. of Marlborough, m. 1756 Henry Herbert (1734-1794) 10th E. of Pembroke (1734-1794) who eloped with Kitty Hunter in 1762, mo. of Lord Herbert (1759-1827) 11th E. who $\mathrm{m}$. 1787 his cousin Elizabeth (d. 1793) da. of Topham Beauclerk and grda. of $3 r d \mathrm{D}$. of Marlborough.

Ly of the Bedchamber to Queen 1783-1818.

Herbert, Mary (d. 1769) Ct. of Pembroke

da. of Richard, Vct. Fitzwilliam, m. (1) Henry Herbert (1693-1751) 9th E. of Pembroke the "Architect Earl", m. (2) North Ludlow Barnard.

Hereford SEE Devereaux

Hertford SEE Seymour

Heytesbury SEE A'Court

Hickman, Sarah (d. 1838) Cts of Plymouth, Ly Amherst da. of Andrew, Ld. Archer, m. (1) 1778 other Hickman, 5th E. of Plymouth, m. (2) William Pitt, Ist E. Amherst [Lady Helland Journal vol. I, p. 20].

Hi11, Arthur (1753-1801) VCt Fairford, 2nd M. of Downshire s. of Wills Hill, 1st $E$. of Hillsborough and 1 st $M$. of Downshire, bro. of Ly Salisbury, m. 1786 Mary, da. of Col. Martin Sandys, $7 \mathrm{ch}$.

Tory MP.

Hobart, Albina Bertie (1738-1816) Cts. of Buckinghamshire da. and coh. of Ld. Vere Bertie, $s$. of Robert 1 st D. of Ancaster, m. 1757 George Hobart (1731-1804), 3rd E. of Buckinghamshire. 
Famous for her obesity, theatricals, campaigning at the 1784 Westminster Election, and her faro table.

Hobhouse, John Cam (1786-1869) Bn Broughton de Gyffard

$s$. of Benjamin Hobhouse, Bt, $m$. 1828 Julia Tomlinson, da. of George, 7th M. of Tweeddale. $3 \mathrm{ds}$.

Radical politician, friend of Byron, MP 1820-51, in

Melbourne cabinet, invented term "His Majesty's Opposition" [DBH].

Holderness, Mary Doublet (1721-1801) Cts of Holderness da. of Francis Doublet of Holland, $m$. 1743 Robert, 4th $E$. of Holderness (1718-1778), Governess to the Pss. of Wales.

Holland, Henry (1788-1873) Dr.

s. of Peter Holland physician, cousin of Mrs. Gaskell the novelist, $m$. (1) 1822 M. E. Caldwell (d. 1830), da of james Caldwell, $2 \mathrm{~s}, \mathrm{~m}$. (2) $1834 \mathrm{saba}(\mathrm{d} .1866)$, da. of Rev. Sydney Smith, 3 das.

Holland, Lord and Lady SEE FOX

Hood, Samuel (1724-1816) Vct Hood

Naval commander in North America 1767-70, MP, Pitt cabinet.

\section{Howard, Rosalind Frances}

da. of Henrietta Maria Stanley (1807-1895) promoter of Girton and women's education and Edward John Stanley (18021869) 2nd Bn Stanley, $m$. George James Howard 9 th E. of Carlisle.

Howard, Charles (1746-1815) 11th D. of Norfolk

m. (1) 1767 Marian, da. of John Coppinger, m. (2) 1771 Frances, da. of Charles Fitzroy Scudamore, he was suc. by his cousin.

Whig supporter, and a Protestant [Lady Hol] and Journa] vol. 2, p. 9].

Howard, Frederick (1748-1825) 5th E. of Carlisle

m. 1770 Margaret Caroline Leveson Gower (1753-1824), da. of Ist M. of Stafford, half sis. of Ld. Granvilie, 4s. 3das. Member of the Devonshire House circle, poet. Aspinall Later vol. 5, p. 653, n. 4 .

Howard, George (1773-1848) 6th E. of Carlisle

e. s. of Frederick Howard, 5th E., m. 1801 Georgiana Cavendish (Little G) (1783-1858), dá. of Georgiana Ds. of Devonshire, $12 \mathrm{ch}$. 
Howard, George William Frederick (1802-1864) 7th E. of Carlisle, Ld Morpeth

e. S. of Little G, da. of Georgiana, Ds. of Devonshire, never married, suc. by his brother Hon. Rev. William George Howard as 8 th $\mathrm{E}$.

Howard, Georgiana Dorothy Cavendish (Little G) (1783-1858) Ly Morpeth, Cts of Carlisle

e. da. of Georgiana, Ds of Devonshire, m. 1801 to George Howard, 6 th E. of Carlisle (1773-1848), Ld Morpeth until 1825, MP, Grey's cabinet, 6s. 6da.

letters of 3 of her daughters have been published. The letters date from 1825-1870. The daughters were Caroline Lascelles, Georgiana Ellis, and Harriet Granville.

Howard, Isabella (d. 1795) Ly Carlisle

da. of William 4 th Ld. Byron, $m$. (I) as 2 nd wife Henry Howard (1694-1758) 4th E. Of Carlisle, m. (2) Sir William Musgrave.

Howard, Margaret Caroline Cavendish Leveson Gower (d. 1824) Ly Carlisle

da. of Granville, 1st M. of Stafford, m. 1770 Frederick, 5th E. of Carlisle (1748-1825), Ld. Lt of Ireland 1780-2, 4s, 3das [Lady He] Iand Journal vol. 1, p. 194].

Howick SEE Grey

Huskisson, William (1770-1830)

s. of William Huskisson, m. 1799 Elizabeth Emily

Milbanke, da. of Adm Mark Milbanke, cousin of Ly Cowper, no issue.

Tory politician with Canningite leanings, cabinet 1823-7, leader of the Commons, killed by train at the opening of the Manchester \& Liverpool Railway.

Ingram, Frances Gibson Shepherd (d. 1807) Ly Irwin

m. Charles Ingram 9 th and last Vct Irwin ox Irvine, 5das, mo. of Ly Hertford and Francis Ingraham Shepherd who $\mathrm{m} .1781$ Sir William Gordon (1744-1823), bro. of 4 th D. of Gordon. Earlier in 1769, he had eloped to scotland with Ly Sarah Bunbury.

in 1782 she wanted her son-in-law, William Gordon, to be appointed vice-Admiral of Scotland and to hold office personally, not in the name of his bro., the D. of Gordon. The King objected, but Ly Irwin succeeded in pushing Dundas to change the King's mind. William Gordon was appointed to the position in his own name [N\&B].

Jekyll, Joseph (d. 1837) wit and politician

s. of Edward Jekyll, captain RN, m. 1801 Maria, da. of Hans Sloane, MP for Lostwithiel, Cornwall, $2 \mathrm{~s}$. 
MP Calne (1787-1816), Solicitor-General 1805, Master in Chancery 1815 [Jekyl] Letters p. 176].

Jenkinson, Robert Banks (1770-1828) 2nd E. of Liverpool, Ld Hawkesbury until 1808

s. of Charles Jenkinson (1727-1808), 1st E. of Liverpool, m. (1) 1795 Louisa Theodosia Hervey (d. 1821), da. of 4th $E$. of Bristol (the Earl-Bishop), sis. of Elizabeth Foster, m. (2) Miss Chester, da. of Charles Chester, niece of 1st Ld Bagot.

Tory PM 1812-1827

Jersey SEE Villiers

Jocelyn, Robert (1788-1870) 3rd E. of Roden, Bn Clanbassil

s. of Robert, 2nd E. and Frances Theodosia Bligh, m. (1) 1813 Maria Frances Catherine (d. 1861), da. of Thomas, Ld de Spencer, 3s 3da., m. (2) 1862 Clementina Janet, da. of Thomas Andrews and wid. of Capt Robert Lushington Reilly, suc. fa 1820, cr. Bn Clanbassil 1821, Great Master of the Orange Society.

Kemble, Frances Anne (Fanny) (1809-1893) actress and author da. of Charles Kemble, actor and part owner of Covent Garden and Maria Theresa de Camp, actress and playwright, $m$. 1834 Pierce Butler, rich American, div. 1850 Journals published in 1835, offended many [DBH].

Reppel, George (1724-1772) Id Bury, 3rd E. of Albemarle s. of William, 2nd Earl and Lady Anne Lennox, suc. fa 1754, m. 1771 Anne (d. 1824).

liberal politician, close friend of Horace Walpole

Keppel, William Charles (1772-1849) 4th E. of Albemarle s. of George Keppel (1724-1772) 3rd E. and Anne (d. 1824) da. of Sir John Milier, Bnt.

\section{Kinnoull SEE HaY}

Lamb, Caroline Ponsonby (1785-1828) novelist

da. of Henrietta Frances Spencer (Harriet) Ponsonby and Frederick 3rd E. of Bessborough, sis. of Georgiana, Ds of Devonshire, m. 1805 to William Lamb, Ld. Melbourne (17791848), 1s. Augustus Frederick Lamb (1807-1836), affair with Ld. Byron, the poet. mentally unstable, published 1816 Glenarvon, caricature of political and social life of her times.

Lamb, Elizabeth Milbanke (1752-1818) Ly Melbourne

da. of Sir Ralph Milbanke, 5th Bt of Halnaby in Yorkshire and Elizabeth da. and coh. of Edward Deleval, m. 1769 Peniston Lamb, later 1st Vct. Melbourne, cr. $1770 \mathrm{Bn}$ of 
Kilmore, cr. 1781 Vct. Melbourne, Gentleman of the Bedchamber to P. of Wales, 1783-96, Byron m. her niece, Annabella Milbanke.

Lamb, Frederick James (1782-1853) 3rd Vct Melbourne and Bn Beauvale

3rd s. of Ly Melbourne and Peniston, 1st Vct Melbourne, suc. bro., William Lamb, as 3rd Vct. Melbourne and cr. 1839 Bn Beauvale, m. 1841 Cts. Alexandrina Julia (b. 1818), da. of the Count of Maltzahn, the Prussian Amb. at Vienna. He was 40 years older than wife.

Whig politician and diplomat, known for scandalous affairs [Second self p. 305].

Lamb, George (1784-1834)

4th s. of Ly Melbourne, m. 1809 Caroline Rosalie Adelaide St. Jules (1786-1862) illeg. da. Of Elizabeth Foster and 5 th D. of Devonshire, no issue. Prince of Wales was alleged to be his father. She had affair with Brougham.

Whig politician and lawyer [Second Self p. 305].

Lamb, William (1779-1848) 2nd Vct Melbourne

m. 1805 Caroline Ponsonby, da. of Harriet Spencer Ponsonby, Ly Bessborough.

Whig PM 1834, 1835-41, Whip MP 1806-1828, supporter of Canning, Queen Victoria's mentor.

Lambton, Louisa Elizabeth Grey (1797-1841) Cts of Durham da. of Charles Grey, m. 1816 John George Lambton (17921840), E. of Durham, s. of William Henry Lambton and Anne Villiers, da. of George, 4th E. of Jersey, Radical politician, MP 1813-28, Grey's cabinet, Gov-Gen of Canada, 5 ch. 64].

Whig, Ly of the Bedchamber 1837 [Heesom "Sunderland" $p$.

Lansdowne SEE Petty-Fitzmaurice

Lascelles, Caroline (d. 1881)

da. of Georgiana Howard, Little G, grda. of Georgiana, Ds of Devonshire, m. 1823 William Sebright Lascelles (17981851), s. of 2nd E. of Harewood, MP 1820 Northallerton, MP 1837 Knaresborough, member of the Privy Council.

Law, Edward (1790-1871) 2nd $\mathrm{Bn}$ and 1st $\mathrm{E}$. of Ellenborough

s. Of Edward, 1st Bn Ellenborough, Chief Justice of England, bro. of Elizabeth Susan Law (d. 1883), m. to 2nd Ld Colchester, m. (1) 1813 Octavia stewart (d. 1819), sis. of Ld Castlereagh, m. (2) 1824 Jane Elizabeth, da. of Adm. Henry Digby, div. 1830, no issue.

Gov.-Gen. of India 1841-44, Peel's cabinet. 
Lawrence, Elizabeth Sophia (1761-1845)

da. of William Lawrence (d. 1799) and grda. and coh. of William Aislabie (d. 1781).

Sole proprietor of Ripon, a burgage borough from 18071845. Shared control with her sis. until 1807.

Leach, John (1760-1834) Master of the Rolls 1827-1834.

Leinster SEE Fitzgerald

Lennox, Charles (1735-1806) 3rd D. of Richmond and Lennox $\mathrm{s}$. of Charles, 2nd D. and Ly Sarah Cadogan, uncle of Charles Fox. diplomat, cabinet of Rockingham and pitt.

Lennox, Charles (1764-1819) 4th D. of Richmond s. of Lieut-Gen George Henry Lennox, m. 1789 Charlotte (1768-1842), da. of Jane, Ds of Gordon, suc. uncle in 1806, $14 \mathrm{ch}$.

army, host of famous ball before Waterloo, Pittite MP, gov-gen of British North America 1818.

Lennox, Charles Gordon (1791-1860) 5th D. of Richmond, Ld March

m. 1817 Caroline Paget (d. 1874), da. of Ist M. of Angelsey., $10 \mathrm{ch}$.

Tory MP, Grey cabinet

LeMarchant, Denis (1795-1874) Bt, politician

s. of Maj-gen John Gaspard LeMarchant, m. 1835 Sarah Elizabeth Smith, $4 \mathrm{ch}$.

pvt. sect. to Brougham, held various posts under

Melbourne and Ld. John Russell, Chief Clerk to the House of Commons 1850-1871.

Lespinasse, Julie Jeanne-Eleanore de (1732-1776)

illeg da. of Comtesse de Alban.

French salonist, companion to salonist Mde. de Deffand 1754-1764, set up own salon 1764 [Uglow 1989]

Leveson-Gower SEE Granville

Lewis, Mary Anne Wyndham (1792-1872) Vcts Beaconsfield m. (1) 1815 Wyndham Lewis (d. 1838), a Tory MP, m. (2) 1839 Benjamin Disraeli, $1868 \mathrm{cr}$. VCts Beaconsfield [EBW].

Liddell, Henry Thomas (1797-1878) 1st E. Of Ravensworth e. s. of Thomas Henry Liddell (1775-1855) 6th Bnt., and Maria Ravensworth da. and coh. of John Simpson, $m$. Isabella Horatia (d. 1856) e. da. of Ld George Seymour, $5 \mathrm{~s} 8$ das. 
Tory, unsuccessfully contested seat in Northumberland in Feb 1826, won the next election 4 months later.

Lieven, Dorothea Christophorovna (1785-1857) Princess da. of German General de Beckendorff, m. 1800 Count Christopher Andreievitch Lieven (1774-1839), Russian Amb. to Britain in 1812-1834, $2 \mathrm{~s}$. who died before her.

she maintained close relationship with $P$. Metternich, provided him with political information she obtained from her close contacts with politicians of both parties. Her letters to Metternich have been published. She also maintained close relationships with many of the male politicians of her day, including Grey, Palmerston, and Melbourne. She was a famous social leader, a patroness at Almack's.

\section{Lister, Anne (1791-1840)}

da. of Jeremy Lister, captain in American War and Rebecca Battle, relative of Lord Ribbelesdale.

Tory landowner, owner of Shibden Hall in Yorkshire.

known as "Gentleman Jack" [Lister I Know p. xxiii].

Liverpool SEE Jenkinson

Londonderry SEE Stewart

\section{Longford, Dowager Lady}

m. Edward Michael 2nd Bn. Longford (1743-1792), suc. fa. in 1766 .

\section{Lonsdale SEE Lowther}

Louis Phillipe (1773-1850) King of France, Duc de Chartres $s$. of Duc'd orleans, brought up by Mde. de Genlis, French salonist, m. 1800 Marie Amelia, da. of Ferdinand I, King of the Two Sicilies.

reigned 1830-1848, abdicated 1848, suc. by Napoleon III.

Lowther, Katherine (d. 1764) Ly

da. of Sir James Pennington, 2nd Bnt MP Muncaster, $m$.

Robert Lowther, cousin of James Lowther (1673-1755), mo. of James Lowther (1736-1806) 5th Bnt, very wealthy. She remarried.

she controlled the borough of Appleby.

Lowther, James (1736-1802) 5th Bnt, 1st E. of Lonsdale e. s. of Robert Lowther and Katherine, da. of Sir james pennington, m. 1761 Ly Mary stuart, da. of John, 3 rd E. of Bute, no issue, suc. by cousin Sir william Lowther.

Whig then Tory "Bad Earl" [DNB].

Lyndhurst SEE Copley 


\section{Lyon SEE Bowes}

Lyttelton, Sarah Spencer (1787-1870) Lady

da. of George John, 2nd Ld Spencer and Lavinia Bingham, niece of Georgiana, Ds. of Devonshire, sis. of John Charles, Vct. Althorp $(1782-1845)$, m. William Henry Lyttelton (d. 1837), $5 \mathrm{ch}$.

Lady in Waiting to Queen Victoria, Royal Governess.

Macartney, George (1737-1806) 1st E.

s. of George Macartney and Elizabeth, da. of Stephen winder, m. Ly Jane Stuart (d. 1768) da. of John stuart, 3 rd E. of Bute, no. issue.

Irish diplomat, Chief sect. of ireland, headed 1st diplomatic mission to China in 1792, 1st Gov. of Cape of Goodhope, father was a good friend of the Hollands.

Macaulay, Thomas Babington (1800-1859) 1st Bn Macaulay

s. of Zachary Macaulay (1768-1838), Philanthropist

Whig politician and historian, contributor to the Edinburgh Review, entered Commons in 1830, cabinet 1839-41, 46-8.

Malet, Marian Dora Ly

da. of John Spaulding and Mary Anne Eden Spaulding Brougham, stepdaughter of Brougham, m. 1834 Sir Alexander Malet (1800-1886) 2nd Bnt of the Foreign Office, $2 \mathrm{~s}$.

\section{Malmesbury SEE Harris}

Manners, Charles (1754-1787) M. of Granby, 4th D. of Rutland s. of John Manners, M. of Granby and Frances Seymour, da. of Charles, 6th D. of Somerset, m. 1775 Mary Isabella (17561831), da. of Charles Noel, 4 th D. of Beaufort, $4 \mathrm{~s}$ 3das., suc. fa as 4 th $D$. in 1779 .

Ld.-It. of Ireland 1784-1787, close friend of Pitt, Shelbourne's cabinet.

Manners, Elizabeth Howard (1780-1825)

da. of Frederick, 5th E. of Carlisle, m. 1799 John Henry Manners, 5th D. of Rutland (1778-1857) [Jr] of Mrs. A. vol. 1, p. 167, n. 2].

Manners, John Henry (1778-1857) 5th D. of Rutland

$s$. of Charles Manners (1754-1787), 4th D. of Rutland and Ly Mary Isabella Somerset (d. 1831) da. of Charles 4 th D. of Beaufort.

Tory supporter, anti-reformer. 
Manners, Maria Isabelia Somerset (1756-1831)

da. of Charles Noel Somerset, 4th D. of Beaufort, m. 1776

Charles Manners, 4 th $\mathrm{D}$. of Rutland, $7 \mathrm{ch}$.

became well-known as the "Beautiful Duchess of Rutland",

Tory supporter [Devonshire Angle Saxon Review June $1899 \mathrm{p}$. 227, n. 2].

Manners, Robert (1758-1823)

s. of Ld. Robert Manners, 8 th $\mathrm{s}$. of 2nd D. of Rutland.

Tory MP Great Bedwin, Cambridge [Aspinall Later vol. 1, p. 117, n. 3].

Marlborough SEE Spencer or Churchill

Melbourne SEE Lamb

Melville SEE Dundas

Metternich, Clemens Wenzel Nepomuk Lothar von (1773-1859)

Prince

m. Pss Eleanore Kaunitz, affair with Pss Lieven.

Austrian Amb., Foreign Affairs Minister [Second Self $p$. 306].

Milbanke, Ralph 6th Bnt

S. of Ralph (1721-1798), 5th Bnt, bro. of Elizabeth, Ly Melbourne, fa. of Anne Isabella (Annabella) who m. $1815 \mathrm{Ld}$ Byron the poet.

Milnes, Richard Monckton (1809-1885) Ist Bn Houghton

s. Of Robert Pemberton Milnes (1784-1858) and Henrietta Maria Monckton, da. of 4 th Vct Galway, m. 1851 Annabel Crewe (d. 1874), da. of 2nd Bn Crewe, is 2das.

Tory MP, parliamentary reform supporter, writer.

Milton SEE Fitzwilliam

Minto, LY SEE Eliot +-1806

Molyneux, Maria Craven (1769-1851) Cts Sefton

da. of William, 6 th Bn Craven, m. 1792 William Philip

Molyneux (1772-1838), 2nd E. Sefton [Ilchester Chronicles p. $178]$.

Monckton SEE BOYle

Monson, Sarah Savile (d. 1851) Bns Monson, Cts. of Warwick da. of John, 2nd E. of Mexborough, m. (1) John George Monson, (d. 1809) 4th Bn Monson, is, m. (2) 1816 Henry Richard Greville, 3rd E. of Warwick.

close friend of Mrs. Arbuthnot [Jr] of Mrs. A. vol. 1, p. 88, n. 1]. 
Montagu, Louisa Corry Cts. of Sandwich

da. of Armar, lst E. of Belmore, m. to 6 th $E$. of Sandwich.

she tried in 1828 to marry Ld Seymour, Edward Adolphus 12 th D. of Somerset. Ly Holland said "'he escaped the toils of that veteran coquette'" [Lady Holland to Son May 1822],

Montagu, Elizabeth (1720-1800) Bluestocking, salonist da. of Matthew Robinson and Elizabeth Drake, m. 1742 Edward Montagu (d. 1775), Whig MP, cousin in law to Ly Mary Wortley Montagu.

Samuel Johnson called her "Queen of the Blues." Other members of her salon included: the Thrales, Burneys, Burke, Wilberforce, Joshua Reynolds. Salon lasted for 50 years [Georgiana ed Bessborough p. 39].

Montagu, Isabella (d. 1786) Ds of Manchester, Cts Beaulieu

m. (1) 1723 William Montagu, 2nd D. of Manchester, m. (2) 1743 Edward Hussey, cr. 1762 Bn Beaulieu, cr. 1784 E. of Beaulieu. friend of Horace Walpole.

Montagu, Mary Wortley Pierrepont (1689-1762)

da. of Evelyn Pierrepont, 5 th $\mathrm{D}$. of Kingston and Mary, da. of William Fielding, E. of Denbigh, m. 1712 Edward Wortley Montagu (d. 1761), Amb. to Turkey 1716-18 and Whig politician, $2 \mathrm{ch}$, her da. m. Ld. Bute, Tory PM, sep. 1839, she went to live in Italy.

Writer, published Letters in 1763 [DBH].

Moore, John (1761-1809)

s. of Dr. John Moore

general, originated light infantry training, leader at Coruna, killed there, MP, Pitt supporter, close friend of LY Hester Stanhope [DBH].

Moore, Thomas (Tom) 1779-1852)

s. of John Moore, grocer, m. 1811 Bessie Dyke.

poet, friend of Byron, Jeffrey, Prince of Wales.

Morpeth SEE Howard

Napier, Sarah Lennox Bunbury (1745-1826) Ly Bunbury, Ly Napier

4 th da. of Charles, 2nd D. of Richmond, sis. to Ly Caroline Fox, Later ist Ly Holland, many thought she would marry George III, m (1) 1762 Charles Thomas Bunbury, the racing MP, div. $1776, \mathrm{~m}$ (2) 1781 George Napier, s. of Francis Scott, 5th Ld. Napier, $8 \mathrm{ch}$. including william Napier.

Whig supporter. 
Napier, William Francis Patrick (1785-1860)

3rd $s$. of George Napier and Ly Sarah da. of 2 nd D. of Richmond, m. 1812 Caroline Amelia, da. of Henry Fox, niece of the statesman, 1 s 6 das.

s. of Ly Sarah Lennox Bunbury napier, friend of Charles Stanhope, half bro. of Ly Hester and befriended by Ly Hester and William Pitt.

Nassau, Amelia Mary Temple Lamb (Emily) (1787-1869) Ly

Cowper, Ly Palmerston

da. of Elizabeth Milbanke Lamb and Peniston Lamb, 1st

Vis. Melbourne, $m$ (1) 1805 to Peter Leopold Francis Nassau,

5th E. Cowper (d. 1837), 5 ch., m (2) 1839 Henry Temple, 3rd

Vis. Palmerston (1784-1865).

Necker, suzanne Curchod (1739-1817) Swiss writer, salonist, and philanthropist

da. of minister, m. 1767 Jacques Necker, French banker and politician, mo. of salonist Mde. de Stael.

Newcastle SEE Pelham-Clinton

Newcastle SEE Pelham-Holles

Newcastle, Ds. of SEE Crauford, LY

Norfolk SEE Howard

Normanby SEE Phipps

North, Anne (d. 1797) Ly North

da. of George Speke, m. 1756 Frederick North PM, 4s 3ds.

North, Frederick (1732-1792) Ld North, 2nd E. of Guilford s. of Francis, 1st E. of Guilford (1704-1790) and 1st wife Lucy Montagu (d. 1734), da. of George Montagu, 2nd E. of Halifax.

PM 1770-82, during American war and Fox-North Coalition.

Northumberland SEE Percy

o'Connell, Daniel (1775-1847)

Irish nationalist, lawyer, founder of Catholic

Association in 1823, elected to Parliament from Co. Clare.

Orford, Ly SEE Walpole

Osbaldston, Jane (1757-1821)

da. of Thomas Head of Langley, Bnt, m. George Osbaldston, MP Scarborough (d. 1794), mo. of George (Squire) Osbaldston (1.786-1866), MP 5 years. supporter of Milton/Fitzwilliam [N\&B]. 
Ossory SEE Fitzpatrick

Paget, Henry William (1768-1854) 1st M. of Anglesey,

s. of Henry Paget, E. of Uxbridge (d. 1812), m. (1) 1795 Caroline Elizabeth Villiers, da. of E. of Jersey, 8 ch., div. 1810, m. (2) Charlotte, da. of E. Craven, the div wife of Henry Wellesley, $6 \mathrm{ch} ., \mathrm{cr}$. M. of Anglesey in 1815.

MP 1790-1810, Canningite, in office under Canning, Grey, and Russell, army colonel, at Coruna and Waterloo.

Paine, Thomas (1737-1809) writer Rights of Man

s. of Joseph Paine and Frances Cocke, m. (1) 1759 Mary Lambert (d. 1760), m. (2) 1771 Elizabeth Olive (d. 1808), sep. 1774 .

Palmella, Pedro de Souza-Holstein (1781-1850) D. of

Portuguese amb. to Britain 1819-1820, 1825-1827, Foreign Affairs Secretary, PM, supporter of Pedro and Dona Maria against Don Miguel, close friend of the Hollands. Holland House Diaries p. 429, n. 86].

Palmerston, LY SEE Cowper, LY

Palmerston, Ld. SEE Temple

Peel, Robert (1788-1850) 2nd Baronet

s. of Robert Peel, wealthy cotton magnate, m. 1820 Julia Floyd (1795-1859), da. of General Sir John Floyd, 7 ch.

Tory PM 1834-5, 1841-6, Home Sect. 1822-7. After split in Tory party over the Corn Laws of 1846, Peel was kicked out of office and joined the Russell Whigs [DBH] .

\section{Peirse, Charlotte}

grda. Of Henry Peirse of Bedale, Yorkshire (1754-1824), former MP for Northallerton and Charlotte Grace Monson, da. of John, 3rd Bn Monson, da. of Inigo Thomas of Ratton, Sussex and Charlotte, da. of Henry Peirse.

largest landowner in East Riding, a Tory, her family controlled Northallerton borough since $17 \mathrm{th}$ century [Gash Politics in the Age of Peel p. 219].

Pelham, Thomas (1756-1826) 2nd E. of Chichester

s. Of Thomas Pelham, 1st E., m. 1801 Mary Henrietta Juliana Osborne (1776-1862), da. of Francis, 5th D. of Leeds, and Bns Conyers, da. of Ly Holderness, $8 \mathrm{ch}$.

Whig MP, Irish sect and Home sect, close friend of Fox, Windham, and Prince of Wales [Aspinall Later vol. 1, p. 12, n. 2] . 
Pelham-clinton, Henry Fiennes (1720-1794) 2nd D. of Newcastle

2nd $s$. of Henry Clinton, 7th E. of Lincoln and Lucy Pelham, da. of Thomas, Ist Ld. Pelham and sis. of Thomas, 1st D. of Newcastle and sis. of Henry Pelham, PM also 9th E. of Lincoln, m. 1744 Catherine Pelham, da. of his uncle Henry Pelham, PM, suc. uncle, Thomas Pelham-Holles, Ist D. in 1756 and added name of Pelham.

Pelham-Holles, Thomas (1693-1768) 1st D. of Newcastle s. of Thomas Pelham, 1st Ld. Pelham and Grace Holles, da. of Gilbert Holles, 3rd E. of Clare, m. 1717 Henrietta (d. 1776), da. of Francis, 2nd E. of Godolphin and grda. of John Churchill, D. of Marlborough, no issue, suc. Uncle John Holles whose name he added, bro. to Henry Pelham, Ist Ld. of the Treasury 1754-57 with Pitt the Elder, Id. Privy Seal under Rockingham 1765-6.

Pembroke, Lady SEE Herbert

Perceval, Spencer (1762-1812)

S. of John Perceval, 2nd E. of Egmont and Catherine, da. of Charles Compton, m. 1790 Jane, da. of Thomas SpencerWilson, $12 \mathrm{ch}$. assassinated in office [DBH].

Tory PM 1809-12.

Percy, Charlotte Florentina Clive (d. 1866) Ds of Northumberland

2nd da. of Edward E. of Powis, grda. of Clive of India, m. 1817 Hugh Percy (1785-1847) 3rd D. of Northumberland, e.s. of Hugh Percy (d. 1817) 2nd D. by his 2nd wife, no issue, he was suc. by bro. Algernon.

Tory, Governess to Princess Victoria [Holland House Diaries p. 478 , n. 123].

\section{Percy, Elizabeth Seymour (Ly Betty) (1715-1776) Ds of} Northumberland

da. of Algernon Seymour, D. of Somerset and Frances Thynne, da. of Thomas, 1st Vct Weymouth, heiress to Percy Barony in Northumberland, m. 1740 Hugh Smithson (1715-1786) who took Percy name, cr. 1st D. of Northumberland of the $3 r d$ creation in 1766, MP 1740-1751. Close friend of Bute, 4 ch.

Tory, Ly of the Bedchamber to Queen Charlotte.

Petty-Fitzmaurice, Henry Thomas (1780-1863) 3rd M. of Lansdowne

s. of William Petty, 1st M. of Lansdowne and LY Louisa Fitzpatrick, da. of John, E. of Upper Ossory and Evelyn, da. of John, E. Gower, m. 1808 Ly Louisa Emma Fox-Strangeways (d. 1851) da. of Henry Thomas, 2nd E. of Ilchester, $2 \mathrm{~s}$.

Whig politician, but served in liberal Tory cabinets of Canning and Goderich, twice refused premiership. 
Petty, William (1737-1805) 1st M. of Lansdowne and 2nd E. of Shelburne

s. of John Fitzmaurice, E. of Shelburne and Mary Fitzmaurice, m. (1) 1765 Sophia Carteret (d. 1771), da. of John, E. of Granville, m. (2) 1779 Louisa Fitzpatrick (d. 1789), da. of John, 1st E. of Upper Ossory, 1s Henry, 3rd M. Whig, then Tory supporter of Pitt, the Elder, then back to Whig supporter of Rockingham, PM 1782-3, completed Treaty of Versailles to end Amer. War. Distrusted by his contemporaries who called him Malagrida. "One of the most unpopular statesmen of his time."

Phipps, Constantine Henry (1797-1863) 1st M. of Normanby heir to the Tory E. of Mulgrave, m. Maria (d. 1882) da. of Thomas Henry Liddell, 1st Bn Ravensworth. One of the Whig women involved in the Bedchamber Crisis of 1837.

Whig MP 1818-30, Ld. Privy Seal 1834, 1835 Ld. Lt. Ireland, Canningite.

Piozzi SEE Thrale

Pitt, Hester (1721-1803) Cts Chatham

$\mathrm{da}$. Of Richard Grenville and Hester, Cts. Temple, m. 1754 William Pitt, the Elder, 1st E. of Chatham (1708-78)

mo. of William Pitt, the Younger (1759-1806), cr. 1761 Bns Cts. Chatham [DBH].

Pitt, William (the Younger) (1759-1806) Tory PM 1783-1801, 1804-6 [DBH] .

Plunkett, William Conyngham (1764-1854) 1st Bn

4 th s. of Thomas Plunkett and Mary da. Of Redmond Conyngham, m. 1791 Catherine da. of John McCausland, 6s 6 das.

Irish lawyer, Ld. Chancellor of Ireland 1835-1841, friend if the Hollands, fought duel with Castlereagh.

Plymouth SEE Hickman

Ponsonby, John Eric (1770-1855) 2nd VCt Ponsonby, 1st VCt of Imokilly

e. S. of William Brabazon Ponsonby, lst Bn Ponsonby, suc. fa. as 2nd $\mathrm{Bn}$ in 1806, bro. to Mary Elizabeth Ponsonby, $\mathrm{m}$. to Charles Grey, cr. Vct Ponsonby in 1839, m. 1803 Elizabeth Frances Villiers (d. 1866), da. of George, 4th E. of Jersey, no issue.

amb. to Constantinople, Venice, Buenos Aires.

Ponsonby, Frederick Cavendish (1783-1837)

2nd s. of Harriet Spencer Ponsonby, Lady Bessborough, m. 1825 Emily Charlotte, d. of 3rd E. of Bathhurst, 3s. 
army Major-general, Governor of Malta 1826-1835.

\section{Ponsonby, George (1755-1817)}

s. of John Ponsonby (1713-1787), 2nd E. Bessborough's younger bro., m. 1780 Mary Butler, d. of Brinsley, 2nd E. of Lanesborough, 1da.

Whig politician, leader of Opposition in Commons 1808-17, MP Co. Wicklow 1801, Ld. Chancellor of Ireland 1806-7, MP Tavistock 1808-17.

\section{Ponsonby, Henrietta Frances (Harriet) (1761-1821) Ly} Duncannon, Ly Bessborough

da. of Margaret Poyntz and John, 1st E. Spencer, sis. of Georgiana, Ds of Devonshire, m. 1780 Frederick Ponsonby (1758-1844), Vct Duncannon, 3rd E. of Bessborough, Whig MP, 3s 1da. Caroline Lamb, affair with Ld. Granville, 2 ch. [Sheridan Letters vol. 1, p. 207, n. 3].

Ponsonby, John William (1781-1847) Ld Duncannon, 4th E. of Bessborough

s. of Harriet Spencer Ponsonby and Frederick Ponsonby, 3rd E. of Bessborough, m. 1805 Maria Fane, da. of John, 10th E. of Westmoreland, $14 \mathrm{ch}$.

helped prepare the 1832 Reform Bill.

Ponsonby, William Francis (1787-1855) Bn de Mauley

3 rd $s$. of Harriet, Ly Bessborough, m. 1818 Barbara Ashley Cooper, da. of 5 th E. of Shaftesbury, a high Tory family, cr. $1838 \mathrm{Bn}$ de Mauley [Bessborough Lady Bessborough and Her Family Circle p. 6].

Portland SEE Bentinck

Primrose, Hannah de Rothschild (1851-1890) Cts. of Rosebery da. of Bn Meyer de Rothschild and Juliana Cohen, $m$. 1878 Archibald Philip Primrose (1847-1929) 5th E. of Rosebery PM. political hostess, Liberal Party center.

Prince of Wales SEE George IV

Pultney, Henrietta Laura (1766-1808) Bns Bath s.j.

da. William Pultney (d. 1805), MP Shrewsbury, m. Sir James Murray, who took her name, cr. bns in 1792 , Cts. in 1803 .

controlled borough of weymouth [Thorne].

Ramboullet, Catherine de Vivionne (1588-1665) French salonist

da. Jean de Vivionne, French Amb. to Rome, m. 1600 Charles d' Angennes, Marq. de Ramboullet.

salon began in 1610 [Uglow 1989]. 
Recamier, Jeanne Francoiose Julie Adelaide Bernard (17771849)

nee Bernard, m. 1792 Jacques Recamier, rich banker, a man

3 times her age.

salonist.

Richmond SEE Lennox

Robinson, Frederick John (1782-1859) 1st Vct Goderich and 1st $E$. of Ripon

s. of Thomas Robinson, 2nd Bn Grantham and Mary, da. of Philip Yorke, 2nd E. of Hardwicke, m. 1814 Sarah Louisa

Albinia Hobart (d. 1867), da. of Robert 4 th $E$. of

Buckinghamshire.

Tory PM 1827-8 and held office under Grey and Peel.

Robinson, Mary (Perdita) (1758-1800)

nee Darby, da. of a captain of a whaling ship in Bristol, m. 1775 Thomas Robinson, an attorney's clerk, mistress of Prince of Wales, mistress of MP Banastre Tarleton (17541833).

Drury Lane actress.

Roden SEE Jocelyn

Rolle, John (1756-1842) Bn Rolle of Stevenson

s. of Denys Rolle, m. (1) 1778 Judith Maria (d. 1820), da. of Henry Walrond, no issue, $m$. (2) 1822 Louisa Barbara, da. of Robert Trefusis, 17th Bn Clinton, no issue, $c r . B n$ Rolle 1796 .

MP 1780, staunch Pitt supporter, against the Reform Bill.

Rogers, Samuel (1763-1855)

$\mathrm{s}$. of Thomas Rogers, never married.

wit, friend of Fox and Sheridan.

Romily, Samuel (1757-1819)

$s$. of Peter Romilly, jeweler, and Margaret Garnault, da. of French Hugenot, m. 1798 Anne da. of Francis Garbett, 6 s $1 \mathrm{da}$.

lawyer, reformer, Solicitor Gen. 1806, committed suicide in 1819, 3 days after wife died, his children were taken in by the Hollands.

Rosebury, Lady SEE Primrose

Russell, Elizabeth Anne Rawdon (Lady William) (1793-1875) m. 1817 Ld William Russell, 2nd $\mathrm{s}$. of 6th D. of Bedford, mo. of Hastings $(1819-1891) 9$ th $\mathrm{D}$. and 2 other $s$.

"Gifted in languages and intellect, hers was a dominating and rather selfish character" [Second Self p. 307]. 
Russell, Francis (1765-1802) 5th D. of Bedford s. of Francis Russell, M. of Tavistock (d. 1767) and Elizabeth (d. 1768), da. of William Keppel, 2nd E. of Albemarle, did not marry, suc. by bro. John (1766-1839) as 6 th D. Entered House of Lords 1787, close friend of Fox and the Prince of Wales.

Russell, Francis (1788-1861) M. of Tavistock, 7th D. of Bedford

s. of John, 6th D. of Bedford (1766-1839), m. Anna Maria Stanhope (1783-1857), fa. of William, Ld. Russell (18091872) 8th $D$.

Whig Leader, but friend of the Arbuthnots.

\section{Russell, George William (Lord George) (1790-1846)}

2nd $s$. of John, 6th D. of Bedford and Georgiana Byng, m. 1817 Elizabeth Anne Rawdon (1793-1874), da. of John Rawdon, bro. of 1st M. of Hastings, their son, Francis Charles Hastings Russell (Hastings) (1819-1891) was 9th D. of Bedford.

Major-general, Whig MP, Minister at Lisbon, Brussels, Berlin.

Russell, Gertrude Leveson-Gower (1715-1794) Ds of Bedford da. of John, E. Gower, sis. of Richard Grenville (17111779), 1st E. Temple, m. 1737 John Russell (1710-1771), 4th D. of Bedford as 2nd wife, $3 \mathrm{ch}$., one da. Caroline m. 1762 George Spencer, D. of Marlborough.

Russell, John (Lord John) (1766-1839) 6th D. of Bedford m. (1) 1786 Georgiana Byng (d. 1801), da. of George Byng, 4 th Vet Torrington, 3ds. 3s Francis, William, and Ld. John Russell, Whig PM, m. (2) 1803 Georgiana Gordon (1781-1853), da. of Jane, Ds of Gordon, 6s 3das., suc. bro. as 6th D. in 1802 .

parliamentary reformer Commons 1788-1802, 1806 Ld. Lt. of Ireland.

Russell, John (Ld. John) (1792-1878)

3rd s. Of John, 6th D. of Bedford and his 1st wife Hon. Georgiana Byng (d. 1801), m. (1) 1835 Adelaide Lister and Ly Ribblesdale (1807-1838), da. of Thomas Lister, and wid. of Thomas, 2nd Ld. Ribblesdale, 2 ds., m. (2) Frances Anna Maria Elliot (Ly John) (1815-1898), da. of 2nd E. of Minto and Mary Bydone, cr. 1861 lst E. Russell, 3s 2das.

Whig PM 1846-52, 1865-66, Whig MP 1813-1861, travelled with the Hollands to Europe 1808-9, supporter of Parliamentary Reform, drafter of the 1831 Reform Bill.

Russell, William (1809-1872) 8th D. of Bedford s. of Francis, 7th D. of Bedford and Anna Maria Stanhope. MP Tavistock 1832-41 [Lady Holland to her Son p. 164]. 
Russell, William (Lord William) (1767-1840)

3rd son of Francis, M. of Tavistock, bro. of Ld. John Russell, m. 1789 Charlotte Villiers (d. 1808), da. of George Villiers, 4th E. of Jersey, 4s 2 das., he was murdered by his valet.

First Ld. of the Admiralty.

Rutland SEE Manners

Ryder, Elizabeth Terrick (1729-1804) Ly Harrowby

da. and coh. of Richard Terrick, BP of Peterborough and London, m. 1762 Nathaniel Ryder (1735-1803), 1st Bn Harrowby, cr. in 1776, MP, 3s 1 da, mo. of Dudley Ryder.

Ryder, Susan Leveson-Gower (1772-1838) Vcts Sandon, Ct. Harrowby

da. of Granville Leveson-Gower, 1st M. of Stafford, sis. of Ld. Granville, m. 1795 Dudley Ryder (1762-1847), Ist E. of Harrowby, Vct Sandon until 1803, liberal Tory, cabinet Pitt, Addington, Amb. to Berlin 1805-6. suc. fa as 2 nd Bn Harrowby 1803, cr. 1st E. of Harrowby in 1809, 4s 5da. Her s, Dudley Ryder (1798-1882) was Ld. Privy Seal 1855-7.

Sackville, Arabella Diana (1769-1825) Ds of Dorset, Ly Whitworth

da. of Sir Charles Cope, 2nd Bnt. of Brewern, m. (1) John Frederick Sackville, 3rd D. of Dorset (1745-1799), s. of John Philip Sackvilie and Frances, da. of John, E. of Gower, ch., m. (2) Charles, E. Whitworth.

D. Of Dorset left her all the 13,000 per year. Her mo. remarried in 1782 to Charles Jenkinson, later cr. Ld. Liverpool Controlled both seats at East Grinstead 1799-1825 [Thorne].

Salisbury SEE Cecil

Sandon, SEE Ryder

Sandwich, Cts. of SEE Montagu, Elizabeth

Scott, Elizabeth Montagu (1743-1827) Ds of Buccleuch $\mathrm{da}$. and $\mathrm{h}$. of George, 1st D. of Montagu and 4 th $E$. of Cardigan, m. 1767 to Henry Scott (Duke Henry), 3rd D. of Buccleuch and 5th D. of Queensbury (1746-1812), $7 \mathrm{ch}$.

Scott, Charlotte Anne Thynne (1811-1895) Ds. of Buccleuch da. of Thomas, 2nd M. of Bath, m. 1829 to walter Francis scott (1806-1884), 5th D. of Buccleuch and Queensbury. 
Scott, John (1751-1838) 1st E. of Eldon

s. of William Scott, merchant, m. 1772 Elizabeth (d. 1831), da. of Aubone Surtees, banker, $4 \mathrm{ch}$.

Tory Ld. Chancellor for 26 years, lawyer, friend of Andrew Bowes.

Sebright, John (1767-1846) 7th Bnt

s. of John Saunders Sebright, 6th Bnt, m. 1793 Harriet Crofts (d. 1826), da. of Richard Crofts, $8 \mathrm{ch}$.

Whig MP.

Sefton SEE Molyneux

Seymour, Isabella Anne Ingram Shepherd (1760-1836) Ly

Beauchamp, Ly Yarmouth, Cts. of Hertford

da. of Frances Gibson Shepherd Ingram (d. 1807), Vcts Irvine and Charles (d. 1778), 9th and last Vct Irvine, m. 1776 Francis, Ld. Yarmouth as 2nd wife, suc. fa as 2nd Marquess of Hertford in 1794, Vct Beauchamp, E. of Yarmouth until 1794.

affair with George, Prince of Wales [Ginter whig Organization p. 152].

\section{Seymour, Maria Fagnaini}

illeg. da. of 4 th D. of Queensbury (Old Q), m. 1798 Francis Charles Seymour Conway (1777-1842), 3rd M. of Hertford, s. of Francis, 2nd M. and Isabella Seymour Ly Hertford [Second Self p. 304].

\section{Shelburne SEE Petty}

Shelley, Frances winckley (1787-73) Ly Shelley

da. of Thomas Winckley of Preston, Lancs, strong

Jacobite, m. 1807 John Shelley (1771-1852), 6th Bnt, distant cousin of Percy Bysshe Shelley

advisor to the D. of Wellington [Jr]. of Mrs. A. vol. 1, p. $32, \mathrm{n} .2 \mathrm{j}$.

Sheridan, Elizabeth (Betsy) (1758-1837)

da. of Thomas Sheridan, sis. of Richard B. Sheridan, $m$. Henry LeFanu, army captain.

Sheridan, Richard Brinsley (1751-1816) Whig politician and dramatist

m. (1) 1772 Elizabeth Anne Linley (1754-1792), singer, da. of Thomas Linley, musician, m. (2) 1795 Esther Jane Ogle, da. of Newton Ogle, Dean of Winchester.

manager of Drury Lane theater, playwright School for Scandal 1777, friend of Fox and the Prince of Wales. 
Smith, Sydney (1771-1845)

bro. Of Percy and Robert (Bobus) Smith, m. 1800 Catherine Amelia (d. 1852), da. of John Pybus, 4 ch.

parliamentary reformer, friend of Jeffrey and Brougham, Canon at st. Paul's.

Somerset SEE Seymour

Spencer, George (1739-1817) 4th D. of Marlborough

s. of Charles Spencer (1706-1758) 3rd D. and Elizabeth

Trevor da. of Thomas 2nd Ld Trevor, bro. of Ly Betty (d. 1831), m. 1762 Ly Caroline Russell (d. 1811) da. by 2nd wife of John 4 th D. of Bedford, 3 s 5das.

Spencer, George John (1758-1834) Vct Althorp, 2nd E. Spencer s. of John, 1st E. Spencer and Margaret Poyntz, bro. of Georgiana, Ds of Devonshire, m. 1781 Lavinia Bingham (d. 1831), 4s 2das.

Whig politician, after French Revolution sided with Pitt, 1st Ld. of the Admiralty 1794-1800 during the war with France, Home secretary Talents Ministry 1806-7.

Spencer, John Charles (Ld. Althorp) (1782-1845) 3rd E. Spencer

da. of George John Spencer, 2nd E. Spencer and Lavinia Bingham, m. 1814 Esther Acktom, no issue, suc. by his bro. Frederick Spencer, nephew of Georgiana, Ds of Devonshire brought up a Tory, Whig Commons leader 1830-4, close friend of Ld. John Russell, Chancellor of the Exchequer in Ld. Grey's cabinet.

Spencer, Lavinia Bingham (1762-1831) Ly Spencer

da. Of Margaret Smith (d. 1814) and Charles Bingham, 1st E. of Lucan, m. 1781 George John Spencer, 2nd E. of Spencer, mo. of John Charles, Ld. Althorp, and 3rd E. Spencer.

Tory supporter.

Spencer, Margaret Georgiana Ponytz (1737-1814) Ly Spencer da. of Stephen Ponytz, Amb. to Sweden, friend of the 4 th D. of Devonshire, m. 1755 John 1st E. of Spencer (17341783), mo. of Georgiana, Ds of Devonshire and Harriet, Cts. of Bessborough [Masters Georgiana p. 3].

St. Leger, Barry (1737-1789)

army officer, racing enthusiast, founder of the famous horse race in 1776 .

Stafford SEE Granville

Stanhope, Charles Banks (1785-1809)

s. of Charles, 3rd E. Of Stanhope and Louisa, da. of Henry Grenville, bro. of E. Temple and George Grenville, 
half bro. of Ly Hester, killed at Coruna, during the Napoleonic Wars.

Stanhope, Hester Lucy (1776-1839) Ly

da. of Charles, 3rd E. of Stanhope and Hester Pitt (17551780), da. of Ld. Chatham, niece of Pitt, the Younger. political hostess 1803-6.

Stanley, Edward George (1799-1869) 1st Ld Stanley and 14th E. of Derby

m. 1825 Emma (d. 1876)

PM, Whig then independent, entered HC in 1820, Chief Sect. for Ireland, Col. Sect., 1831 sec. from Whigs, passed 1867 reform act, suc. by Disraeli.

Stanley, Edward John (1802-1869) 2nd Bn Stanley

s. of John Thomas Stanley, m. 1826 Henrietta Maria Stanley (1807-1895), da. of Henry Augustus Dillon-Lee, 13th VCt Dillon.

Whig MP, party whip.

Stanley, Elizabeth Hamilton (1753-1797) Cts of Derby

da. of James, 6th D. of Hamilton, m. 1774 Edward Smith Stanley, 12th E. of Derby (1752-1834), he suc. grfa. in 1776, Whig MP, founder of the Derby and the Oaks horse races, $1 \mathrm{~s} 2$ das. [N\&B].

Stewart, Frances Anne Tempest (d. 1865) Ly Londonderry

m. 1812 to Charles William, Ld. Stewart and 3rd M. of Londonderry British Amb. at Vienna, s. of Robert, 1st $M$. and Francis, da. of Ld. Chancellor Camden, half bro. of Robert Stewart, Ld. Castlereagh.

Stewart, Robert (1769-1822) VCt Castlereagh and 2nd M. of Londonderry

s. of Robert, 1st M. (1739-1821) and Sarah Francis,

da. of Francis Seymour Conway, M. of Hertford, m. 1794 Amelia (Emily) Anne Hobart (1772-1829), da. of John Hobart, 2nd E. of Buckinghamshire, niece of Ly Hertford. no issue, suc. by half bro. Charles William stewart.

Tory Foreign Secretary and Leader of the House of Commons 1812-1822, Chief sect for Ireland during 1801 Union.

Committed suicide 1822 .

Strathmore SEE Lyon

Stuart, Frances (1773-1832)

da. of Thomas Coutts, m. 1800 as 2 nd wife 4 th $E$. of Bute and 1st $M$. of Bute (1744-1814). 
Stuart, Georgiana Ryder Wortley (d. 1884)

da. of Dudley Ryder, 1st E. of Harrowby, $m$. John Stuart Wortley (1801-1855) 2nd Bn Wharncliffe.

Stuart, James Archibald Wortley (1776-1845) 1st Bn Wharncliffe

gds. of Ld. Bute, PM, m. Elizabeth Caroline Mary

Creighton (1779-1856), da. of John 1st E. of Erne, cousin to Elizabeth Foster and Ly Londonderry. His sister married into the Dundas family.

MP, Canninite, pro Catholic Emancipation, President of the Council, Lord Privy Seal [Grosvenor First Lady

Wharncliffe $\mathrm{p} . \mathrm{v}$ ].

Stuart, John (1713-1792) 3rd E. of Bute

s. of James, 2nd E. of Bute (d. 1723) and Anne Campbell, da. of Archibald, 1st D. of Argyll, m. 1736 Mary (17181794), da. of Ly Mary Wortley Montagu (d. 1794), she controlled the borough at Bossiney from 1754-1794, $11 \mathrm{ch}$. She $\mathrm{cr}$. Bns Montstuart of Wortley.

PM 1762-3, tutor of George III, close friend of Princess of Wales, mo. of George III.

Stuart, John Crichton-Stuart (1793-1848) 2nd M. of Bute s. of John Stuart, Bn Mountstuart and Elizabeth, da. of Patrick Crichton, 5th E. of Dumfries, m. (1) 1818 Maria (d. 1841), da. of George Augustus North, 3rd E. of Guilford, m. (2) 1845 Sophia (d. 1859), da. of Francis Rawdon Hastings, 1st $M$. of Hastings, $1 \mathrm{~s}$.

Sulivan, Henry William (Harry) (1815-1880)

s. of Elizabeth, sis. of Lord Palmerston and her husband Laurence Sulivan, nephew of Lord Palmerston.

Sutherland SEE Granville

Talleyrand, Charles Maurice (1754-1838)

Uncle of Ds de Dino, famous political hostess.

French Foreign Minister

Tankerville, Countess of SEE Bennet

Temple, Henry (1739-1802) 2nd Vct Palmerston

m. (1) 1767 Frances Poole (d. 1769), da. of Sir Francis Poole, 1da., m (2) 1783 Mary Mee, da. of Benjamin Thomas Mee, and sis. of Benjamin Mee, Director of the Bank of England.

Tory. 
Temple, Henry John (1784-1865) 3rd Vct Palmerston

s. of Henry Temple, 2nd Vct Palmerston and Mary Mee, his 2nd wife, guardian was Ld. Malmesbury, a Whig, m. 1839

Emily, Ly Cowper, after affair of 30 years, no issue.

Sect. at War under 5 administrations Perceval to

Wellington. Came into Parliament under the aegis of Pitt, the Younger. Broke with Tories over his pro-Reform stance in 1830. Continued to be mainly Whiggish, somewhat

Canningite. His Toryism "was oddly diluted" [Guedalla

Palmerston $2: 93$ ].

Temple, Ld. SEE Grenville, Richard Temple (1776-1839).

Thannet SEE Tufton

Tufton, Sackville (1769-1825) 9th E. of Thannet

s. of 8 th E. and Mary da. of Ld John Philip Sackville, sis. of $3 r d$ D. of Dorset, m. 1811 Anne Charlotte de Bojanourt from Hungary, no issue.

in Appleby, Katherine Lowther negotiated a pact with him, friend of the D. of Devonshire. [Bonsall Sir James Lowther p. 2].

\section{Thiers, Adolphe (1797-1877)}

politician and historian. One of the conspirators of the July Revolution, PM 1836, Pres. of the Republic 1871-1873 [Holland House Diaries p. 481, n. 2].

Thurlow, Edward (1731-1806) 1st Bn Thurlow

s. of Rev. Thomas Thurlow (d. 1762), never married.

Ld. Chancellor 1778-1792.

Thrale, Hester Lynch Salusbury Piozzi (1741-1821)

da. of Hester Maria Cotton and John Salusbury, m. (1)

1763 Henry Thrale, brewer and MP (d. 1781), m. (2) 1784

Gabriel Piozzi.

diarist, friend of Samuel Johnson, hostess at Streatham.

Tierney, George (1761-1830)

s. of Thomas Tierney of Limerick, merchant, m. 1789 Miss Miller of Stapleton in Gloucestershire.

Whig Opposition leader 1817-1821, Grey and Canning cabinet [Lady Holland Journal vol. 1. p. 171].

Titchfield SEE Bentinck, William Henry (d. 1824)

\section{Tollemache, Anna Maria}

da. of David Lewis of Malvern Hall, niece of Ld. Shelburne, m. 1773 Wilbraham Tollemache (1739-1821) 2nd s. of Lionel, 4th E. of Dysart and Grace, da. of John, 2nd E. of Granville, suc. bro. as 6th E. of Dysart, through his mo. he is 1st cousin to John, 1st E. Spencer, 
the Spencers got him elected unopposed for Northampton during the elections of 1771 and 1774. Followed spencer politics, not shelburne politics [N\&B].

Townshend, George (1724-1807) 1st M. Townshend

s. of Charles, 3rd Vet (1700-1764), s. of half sis. of D. of Newcastle and Henry Pelham, bro. of Charles Townshend, suc. fa as 4 th Vct in 1764, cr. 1st M. of Townshend 1787, m. (1) 1751 Charlotte Compton, (d. 1770), Bns de Ferrers s.j., $\mathrm{da}$. of James Compton, $5 \mathrm{th} \mathrm{E}$. of Northampton, $8 \mathrm{ch}$., m. (2) 1773 Anne Montgomery (d. 1819), da. of William Montgomery, 1st Bnt, $6 \mathrm{ch}$. [Burney Early Journals vol. 2, p. 195, n. 14].

\section{Townshend, Georgiana Ann Poyntz}

da. of William Poyntz, cousin of Georgiana, Ds of Devonshire, m. (1) William Fawkener, m. (2) 1787 John Townshend, Ld. John Townshend (1757-1833), Whig MP, Ld. of the Admiralty 1782-3.

Townshend, John (Lord John) (1757-1833)

2nd s. of George Townshend, 1st M. of Townshend, m. 1787 Georgiana Anne, da. of William Poyntz and cousin of georgiana Ds of Devonshire, 3s 6 das.

MP Cambridge Univ, Westminster, and Knaresborough, Lord of the Admiralty, PC 1806.

Turner, Charles (1768-1783) Ld

s. of William Turner, m. (1) Elizabeth (d. 1768), da. of William Wombwell, m. (2) Mary, da. of James Shuttleworth, $2 \mathrm{~s}$ 3das., cr. Bnt 1782 .

MP York $[N \& B]$.

\section{Verney, Mary, Bns Fermanaugh}

suc. to the Verney estates at the age of 55, suc. Ralph Verney (1714-1791) 2nd E. Verney MP m. to Mary da. and $h$. of Henry Herring, dir. of bank of England, no issue [Verney Letters vol. 2, p. 308].

Vesey, Elizabeth (1715-1791)

da. of Sir Thomas Vesey, BP of Ossory, m. (1) William Handcock, MP, m. (2) 1746 Agmondesham Vesey (d. 1785), MP. Bluestocking, salonist.

Victoria (1819-1901)

reigned 1837-1901, da. of Edward, D. of Kent, 4 th son of George III, m. 1840 Albert (d. (1861), her cousin, $9 \mathrm{ch}$.

Villiers, Sarah Sophia Fane (1785-1867) Cts of Jersey

e. da. of John Fane (1759-1841), 10th E. of Westmoreland and Sarah Anne Child, da. of Robert Child, banker, m. 1804 George, 5th E. of Jersey $(1773-1859), 8 \mathrm{ch}$. 
Tory, chief patroness at Almack's.

Villiers, Frances Twysden (1753-1821) Cts. of Jersey da. of Dr. Philip Twysden, BP of Raphoe (1735-1805), m. to George Bussy, 4th E. of Jersey, MP, cabinet 1761, $9 \mathrm{ch}$. mistress to P. of Wales, George IV 1794-1800 [Betsy Sheridan's Journal p. 214].

\section{Waldegrave, Ladies}

das. of James 2nd E. of Waldegrave, close friend of Pitt, 1st a Tory then Whig and Maria, illeg. da. of Sir Edward Walpole, bro. of Sir Robert Walpole PM.

Waldegrave, Elizabeth Laura (Laura) (1760-1816)

m. 1782 cousin George Waldegrave, styled Vct Chewton,

later 4 th $\mathrm{E}$. of Waldegrave.

Waldegrave, Charlotte Fitzroy (Maria) (d. 1808)

m. 1784 George Henry Fitzroy (1760-1844) E. of Euston,

s. of 4 th D. of Grafton.

Waldegrave, Anna Horatia (1762-1801) Ly Seymour

m. 1786 Hugh Seymour-Conway, later Ld Hugh Seymour

[Horace walpole vol. 25, p. 68, vol. 30, pp. 350-351, vol. 33 p. 485].

Wallace, Eglantine (1750-1803) Ly Wallace

da. of William Maxwell, sis. of jane, Ds. of Gordon, m. 1772 Thomas Dunlop-Wallace, div. 1778.

playwright, mistress of Dundas, Vct Melville, arrested as a British agent in Paris in 1789 [1:112].

Walpole, Horatio (Horace) (1717-1822) 4th E. of Orford

4 th s. of Sir Robert Walpole, 1st E. of Orford.

founder of Strawberry Hill literary salon, MP, author of gothic novels Castle of oranto in 1764 .

Walpole, Margaret Rolle (d. 1781) Ly Orford, Cts. Clinton

m. (1) 1724 Robert Walpole, 2nd E. of Orford, m. (2) 1751 Sewallis Shirley, cr. Bns Clinton s.j. 1760, niece of Roger Tuckfield, cousin by marriage to Thomas Walpole, mo. of 3 rd E. of Orford.

heiress of the Rolle family of Callington and Ashburton, controlled these two boroughs.

Watson-Wentworth, Charles (1730-1782) 2nd M. of Rockingham, Vct Higham, E. of Malton

s. of Thomas Watson-Wentworth, M. of Rockingham and Mary Finch, da. of 2nd E. of Nottingham, m. 1752 Mary (d. 1804), da. of Thomas Bright/liddell, no issue, suc. by nephew William Wentworth Fitzwilliam, 2nd E. Fitzwilliam.

Whig 1st Ld. of the Treasury $1765-6$ and 1782 leader of the group of Whigs who opposed the American War [DBH].

Wellington SEE Wellesley 
Wellesley, Arthur (1769-1852) 1st D. of Wellington m. 1806 Catherine Pakenham (d. 1831), da. of Edward Michael Pakenham, 2nd Bn Longford, 2s.

Tory PM.

Wellesley, Richard Colley (1760-1842) M. of Wellesley, 2nd E. of Mornington

s. of Garret Wellesley, 1st E. of Mornington and Anne, da. of Arthur Hill, 1st Vct Dungannon, bro. of Arthur Wellesley, 1st D. of Wellington, m. (1) 1793 Hyacinth Gabrielle (d. 1816), da. of Pierre Roland of Paris, had illeg ch. with him, m. (2) 1825 Marianne, da. of Richard Caton of Baltimore, wid. of Robert Patterson, suc fa. 1781, cr. Bn Wellesley 1797, cr. M. Of Wellesley 1799.

Liverpool's and Peel's cabinet, Gov-gen of India, Amb. to Spain, Foreign Secretary, close friend of Brougham, strict conservative $[\mathrm{DBH}]$.

Wentworth, Charlotte Ponsonby (d. 1822) Cts of Fitzwilliam $\mathrm{da}$. of William, 2nd E. of Bessborough and Caroline Cavendish, da. of D. of Devonshire, m. 1770 William Wentworth (1748-1833), 2nd E. Fitzwilliam.

Wentworth, Mary Ly Milton, Cts of Fitzwilliam

da. of Thomas, 1st Ld. Dundas, m. to Charles William Wentworth (1786-1857), 3rd E. Fitzwilliam, known as 3rd Vct Milton, MP for 23 yrs. for Yorkshire, $10 \mathrm{ch}$.

Westmoreland SEE Fane

Wharncliffe SEE Wortley, James

Whitbread, Samuel (1720-1796)

founder of famous brewing firm, Tory. In 1787 Miss Verney sold her interest in the borough of Westover to him for his son Samuel (1758-1815), a Whig and close friend and supported of Fox, Whig opposition leader. Verney Letters vol. 2 p. 289.

Wilberforce, William (1759-1833)

s. of Robert Wilberforce and Elizabeth Bird, m. 1798 Barbara Ann, da. of Isaac Spooner, $4 \mathrm{~s}$.

leader of anti-slavery movement, philanthropist, MP 17801825, close friend of Pitt [DBH].

Wilkes, John (1725-1797)

wealthy middle class family, accepted into the Ton, HellFire Club member, Radical MP for Middlesex, founder of North Briton, arrested for seditious libel, outlawed numerous times, finally allowed into Parliament 1774-1790 [DBH]. 
Wilkinson, Mrs.

son was Marmaduke Larson.

Charles Wilkinson, returned for Boroughbridge in 1774

The Wilkinson family owned property in Aldborough and

Boroughbridge. They managed the electoral interest for the $D$. of Newcastle, who owned most of the burgages. They claimed 1 seat.

William IV (1765-1837)

reigned 1830-1837, known as D. of Clarence from 1789 until 1830, lived with actress Dorothea Jordon 1709-1811, 10 ch., including 1 daughter who married a son of Ly Holland.

Windham, William (1750-1810)

s. of William Windham, MP and Sarah Hicks, m. Cecilia, da. of Commodore Forrest, no issue.

cabinet member under Pitt, Grenville, and Talents

ministry, friend of Burke and Johnson, Whig MP, involved in disputed 1806 election in Yorkshire.

Wortley SEE Stuart

Wortley, Ly SEE Stuart, Georgiana Ryder

Wraxall, Nathaniel (1751-1831) Baronet 2s. s. of Nathaniel Wraxall, m. Jane, da. of Peter Lascelles, Pittite historian.

Wray, Cecil (1734-1805) 13th Baronet

s. of John Wray, 12th Bnt, m. Esther Summers (1736-1825), da. of James Summers.

Whig MP 1768-1784, then turned Pittite, opposed Fox in the famous 1784 Westminster Election.

Wyndham SEE Grenville

Wyndham, Percy Charles (1757-1833)

s. of Charles Wyndham, end E. of Egremont, bro. of George O'Brien Wyndham, 3rd E. secretary and clerk of the Courts of Barbados.

Yarmouth, Amalie Sophie Marianne (1704-1765) Cts. da. of Johann Franz Dietrich von Wendt, gen. in

Hanoverian service, niece of Ly Darlington, m. 1727 Gottlieb Adam von Wallmoden, div, 1739, 2 s., mistress of George II, cr. 1740 Cts. of Yarmouth.

York, Duke. of (1763-1827)

$\mathrm{s}$. of George III, bro. of George Prince of Wales, $m$. Fredericka, Pss Royal of Prussia (1767-1820) 
Yorke, Elizabeth Iindsay

da. of James Lindsay, 5th E. of Balcarres, m. 1782 Philip Yorke, 3rd E. of Hardwicke (1757-1834), s. of Charles Yorke. Suc, uncle as 3rd E. in 1790, PC 1801, Ld. Lt. of Ireland 1801-6, Whig MP but served in Addington and Pitt cabinets, $2 \mathrm{~s} 4$ das. 
APPENDIX B - THE WHIG ARISTOCRACY 


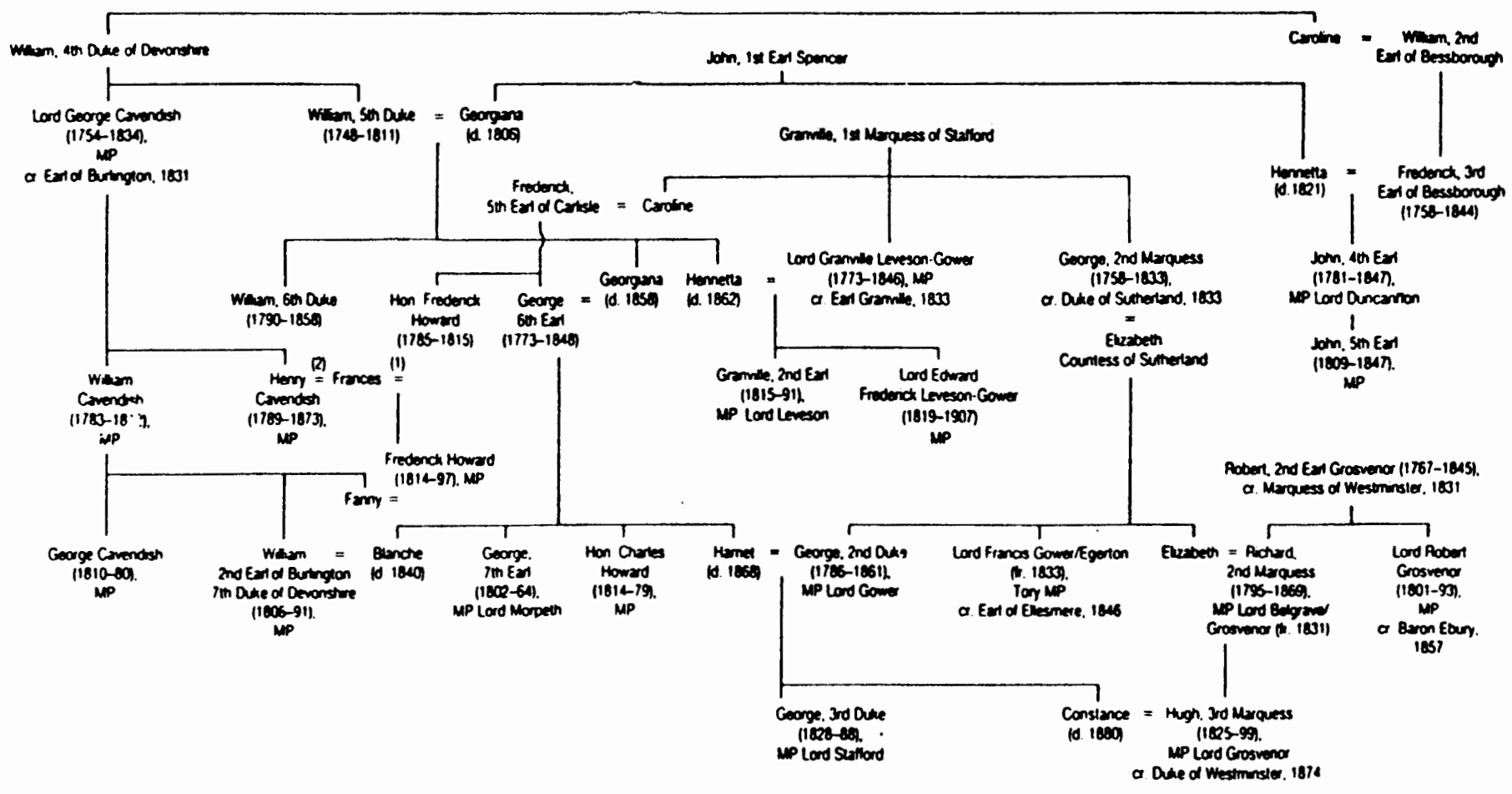

FIG. 1. Sketch of the Grand Whiggery in the Early Nineteenth Century (showing only principal relationships and political figures).

Source: Peter Mandler ARISTOCRATIC Government in +HE AGE of Reform. QRford: CLAReNDON Press, 1990 